\section{Pacific Northwest}

National Laboratory

Operated by Battelle for the

U.S. Department of Energy

\title{
Low Temperature Waste Immobilization Testing
}

\author{
R. L. Russell \\ M. J. Schweiger \\ J. H. Westsik, Jr. \\ P. R. Hrma \\ D. E. Smith \\ A. B. Gallegos \\ M. R. Telander \\ S. G. Pitman
}

September 2006

Prepared for the U.S. Department of Energy under Contract DE-AC05-76RL01830 


\title{
DISCLAIMER
}

This report was prepared as an account of work sponsored by an agency of the United States Government. Neither the United States Government nor any agency thereof, nor Battelle Memorial Institute, nor any of their employees, makes any warranty, express or implied, or assumes any legal liability or responsibility for the accuracy, completeness, or usefulness of any information, apparatus, product, or process disclosed, or represents that its use would not infringe privately owned rights. Reference herein to any specific commercial product, process, or service by trade name, trademark, manufacturer, or otherwise does not necessarily constitute or imply its endorsement, recommendation, or favoring by the United States Government or any agency thereof, or Battelle Memorial Institute. The views and opinions of authors expressed herein do not necessarily state or reflect those of the United States Government or any agency thereof.

\author{
PACIFIC NORTHWEST NATIONAL LABORATORY \\ operated by \\ BATTELLE \\ for the \\ UNITED STATES DEPARTMENT OF ENERGY \\ under Contract DE-ACO5-76RL01830
}

Printed in the United States of America
Available to DOE and DOE contractors from the
Office of Scientific and Technical Information,
P.O. Box 62, Oak Ridge, TN 37831-0062;
ph: (865) 576-8401
fax: (865) 5765728
email: reports@adonis.osti.gov

\footnotetext{
Available to the public from the National Technical Information Service, U.S. Department of Commerce, 5285 Port Royal Rd., Springfield, VA 22161 ph: (800) 553-6847 fax: (703) 605-6900

email: orders@nits.fedworld.gov online ordering: http://www.ntis.gov/ordering.htm
}

This document was printed on recycled paper. 


\title{
Low Temperature Waste Immobilization Testing
}

\author{
R. L. Russell \\ M. J. Schweiger \\ J. H. Westsik, Jr. \\ P. R. Hrma \\ D. E. Smith \\ A. B. Gallegos \\ M. R. Telander \\ S. G. Pitman
}

September 2006

Prepared for the U.S. Department of Energy under Contract DE-AC05-76RL01830

Pacific Northwest National Laboratory

Richland, WA 99352 


\begin{abstract}
The Pacific Northwest National Laboratory (PNNL) is evaluating low-temperature technologies to immobilize mixed radioactive and hazardous waste. Three waste forms - alkali-aluminosilicate hydroceramic cement, "Ceramicrete" phosphate-bonded ceramic, and "DuraLith" alkali-aluminosilicate geopolymer - were selected through a competitive solicitation for fabrication and characterization of waste-form properties. The three contractors prepared their respective waste forms using simulants of a Hanford secondary waste and Idaho sodium-bearing waste provided by PNNL and characterized their waste forms with respect to the Toxicity Characteristic Leaching Procedure and compressive strength. The contractors sent specimens to PNNL, and PNNL then conducted durability (American National Standards Institute/American Nuclear Society [ANSI/ANS] 16.1 Leachability Index and modified Product Consistency Test) and compressive strength testing (both irradiated and as-received samples). This report presents the results of these characterization tests.
\end{abstract}





\section{Executive Summary}

The Pacific Northwest National Laboratory (PNNL) is evaluating low-temperature technologies to immobilize mixed radioactive and hazardous waste. The purpose of this testing is to evaluate the effectiveness of low-temperature or ceramic stabilization technologies as alternatives to conventional waste-immobilization technologies, e.g., vitrification and Portland cement-based grouts. Specific target wastes for immobilization are 1) Hanford Waste Treatment and Immobilization Plant (WTP) secondary waste (HSW) and 2) Idaho Nuclear Technology and Engineering Center (INTEC) sodium bearing waste (SBW). Some of this material may be suitable for treatment and disposal by low temperature $\left(<150^{\circ} \mathrm{C}\right)$ immobilization.

The three waste forms evaluated as part of this low-temperature immobilization study were identified through an unrestricted solicitation that PNNL conducted on behalf of the U.S. Department of Energy. In a request for proposal issued by PNNL on September 1, 2004, proposals were solicited for demonstrations of low-temperature technologies to immobilize mixed radioactive and hazardous waste. For the purpose of the solicitation, low temperature was defined as less than $150^{\circ} \mathrm{C}\left(302^{\circ} \mathrm{F}\right)$. Alternatives to conventional waste immobilization technologies, e.g., vitrification and Portland cement-based grouts, were specifically requested. Relatively mature technologies with the feasibility of deployment in 1 to 2 years were favored by the evaluation criteria. From this solicitation, three waste-form technologies were selected for study:

- Alkali-aluminosilicate hydroceramic cement from the Diagnostic Instrumentation and Analysis Laboratory at Mississippi State University

- "Ceramicrete" phosphate-bonded ceramic from CH2MHILL

- "DuraLith" alkali-aluminosilicate geopolymer from The Catholic University of America Vitreous State Laboratory.

Two different waste-composition simulants, one representing INTEC SBW and one representing WTP HSW, were prepared at Noah Technologies for use in the waste-immobilization test specimens. These simulants were then sent to the three contractors to prepare their waste formulations and products and to measure waste form performance characteristics. The contractor's products had to pass the Toxicity Characteristics Leaching Procedure (TCLP) test as well as exhibit a minimum of $500 \mathrm{psi}$ (3.45 MPa) compressive strength before being sent to PNNL for durability testing.

The scope of PNNL's work was to conduct product consistency testing (PCT) and ANSI/ANS-16.1 durability tests on the waste form specimens and to conduct compressive strength tests on the test specimens submitted by the contractors, both as-received and after irradiation, to a total exposure of $1 \times$ $10^{8} \mathrm{rad}$. All of the tests conducted by the contractors and by PNNL were selected before the waste-form materials were known and were selected to characterize a spectrum of different materials.

In the TCLP, both the Ceramicrete and the DuraLith met the Universal Treatment Standards in $40 \mathrm{CFR} 268.48$ for $\mathrm{Cr}, \mathrm{Cd}, \mathrm{Ag}, \mathrm{Hg}$, and $\mathrm{Pb}$ by more than an order of magnitude. The hydroceramic cement met the UTS limits for $\mathrm{Cr}$, but failed the $\mathrm{Cd}$ and $\mathrm{Hg}$ limits. The Ceramicrete and the DuraLith also met the $3.45 \mathrm{MPa}$ compressive strength criteria by about an order of magnitude with radiation exposure making no difference in the strength. The hydroceramic cement did not consistently meet the 
compressive strength requirement in testing conducted by the contractor. Because it did not meet TCLP or compressive-strength requirements, the hydroceramic cement was not included in any of the testing conducted by PNNL.

The PCT was conducted on Ceramicrete and DuraLith test materials. Using the standard sample preparation process, including washing the crushed and sieved samples with water and ethanol, there was evidence that the samples may be dissolving or otherwise breaking up during the wash step before the test itself was started. To address this issue, the standard crushed samples were washed with acetone, and a larger particle size was also tested. It must be noted that there are concerns that the acetone may also impact the test results. The PCT results are provided in this report for completeness. However, significant work is necessary to understand the waste-form behavior in the PCT and to interpret the results with respect to waste-form performance in a disposal facility.

The Ceramicrete and DuraLith test specimens were also tested using the American National Standards Institute/American Nuclear Society (ANSI/ANS) 16.1 leachability index test method. Both waste forms met the requirement that the leachability index based on $\mathrm{Na}$ be greater than six. The DuraLith waste form was successful in bettering the leachability index target for technetium (LI $>9$ ) with rhenium as a surrogate for the Tc for both waste simulants. However, it did not meet the target index (LI $>11)$ for iodine. The Ceramicrete did not meet the target for technetium in the PNNL testing, and no iodine was detected in the leachate, so only greater-than values could be estimated based on the detection limits. CH2MHill did conduct 7-day ANS-16.1 on Ceramicrete prepared from the HSW spiked with Re and I at concentrations above the nominal simulant concentrations. At these higher spike levels and presumably better analytical sensitivity, they reported leachability indices of better than 11.0. Thus, there is a discrepancy in the results that needs resolution. Both waste forms showed cracking and the formation of white material on the surfaces at the conclusion of the test. In discussions with the contractors, both believe that these observations can be addressed through adjustments in the waste-form preparation.

Ceramicrete phosphate-bonded ceramic and DuraLith alkali-aluminosilicate geopolymer show potential based on the TCLP, compressive strength, and Na leachability index requirements. However, their effectiveness in immobilizing relatively volatile radionuclides, including ${ }^{99} \mathrm{Tc}$ and ${ }^{129} \mathrm{I}$, cannot be asserted without further testing. The ANSI/ANS 16.1 immersion test revealed formulation issues that will need to be addressed for both waste forms. It does not appear that the alkali-aluminosilicate hydroceramic cement is a viable low-temperature immobilization method. Hydroceramic cements may still provide acceptable waste forms when prepared under hydrothermal conditions.

These technologies are at different stages of maturity in waste-form development and optimization, process development and demonstration, and understanding of waste-form characteristics to support disposal system performance assessments. Therefore, they will each require more development if it is decided to pursue either of these alternative low-temperature immobilization technologies.

Development needs common to both waste forms include:

- Address the formulation issues identified through the ANSI/ANS 16.1 testing and perhaps also in the PCT testing.

- Using waste simulants spiked with higher concentrations of I and Re, determine whether the waste forms can achieve sufficient reduction in the release of I and Tc. 
- Based on observations from ANSI/ANS 16.1 testing and contractor thermal cycling tests on Ceramicrete, expand compressive strength testing to include impacts of thermal cycling and immersion in water.

- Optimize the quantities of binder materials to improve waste loading. If acceptable, this may include the removal of water to concentrate the wastes to be immobilized

- Examine other binder materials that may be less costly.

- Demonstrate the long-term effectiveness of sequestering agents added to reduce the mobility of iodine and technetium in the wastes.

- Demonstrate the preparation of the waste forms on a production scale.

- Determine long-term waste-form-performance characteristics to support disposal-system performance assessments. 



\title{
Acronyms
}

\author{
ANL Argonne National Laboratory \\ ANS American Nuclear Society \\ ANSI American National Standards Institute \\ ASTM American Society for Testing and Materials \\ CBPC chemically bonded phosphate ceramics \\ DI de-ionized \\ DIAL Diagnostic Instrumentation and Analysis Laboratory \\ DOE U.S. Department of Energy \\ ETF Effluent Treatment Facility \\ HLW high-level waste \\ HSW Hanford Waste Treatment and Immobilization Plant secondary waste \\ IC ion chromatography \\ ICP-AES inductively coupled plasma-atomic emission spectroscopy \\ INTEC Idaho Nuclear Technology and Engineering Center \\ LAW low-activity waste \\ LERF Liquid Effluent Retention Facility \\ LI Leachability Index \\ LRB laboratory record book \\ LRM low activity reference material \\ NIST National Institute of Standards and Technology \\ NRC Nuclear Regulatory Commission \\ PCT product consistency test \\ PNNL Pacific Northwest National Laboratory \\ RCRA Resource Conservation and Recovery Act \\ RFP request for proposals \\ SBMS Standards Based Management System \\ SBW sodium bearing waste
}


TCLP Toxicity Characteristics Leaching Procedure

TRU transuranics

UTS Universal Treatment Standards

VSL Vitreous State Laboratory

WTP Hanford Waste Treatment and Immobilization Plant 


\section{Contents}

Abstract

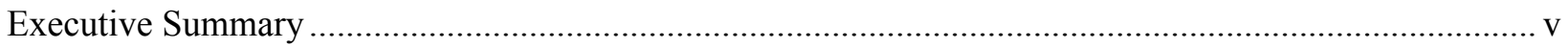

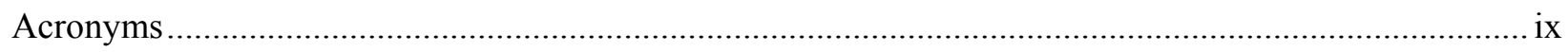

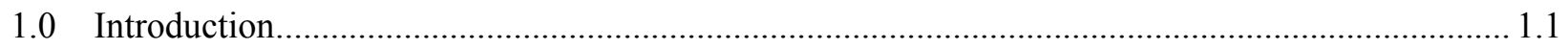

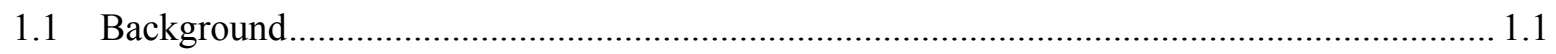

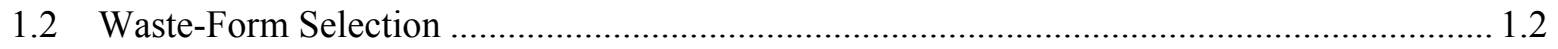

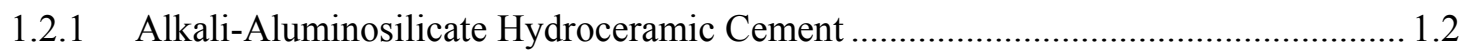

1.2.2 "Ceramicrete" Phosphate-Bonded Ceramic............................................................... 1.3

1.2.3 "DuraLith” Alkali-Aluminosilicate Geopolymer ....................................................... 1.3

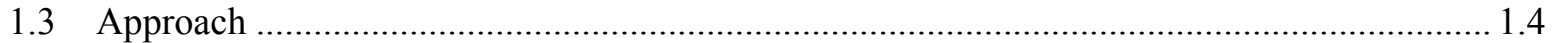

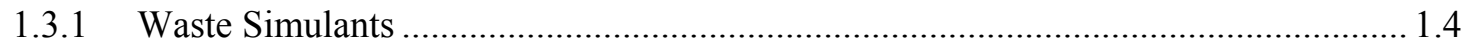

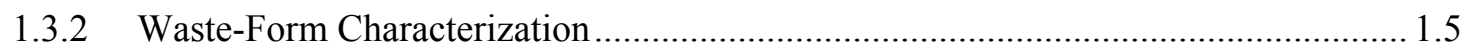

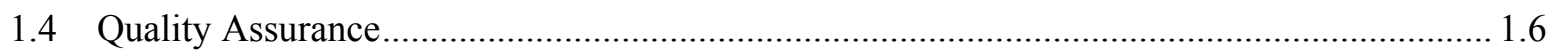

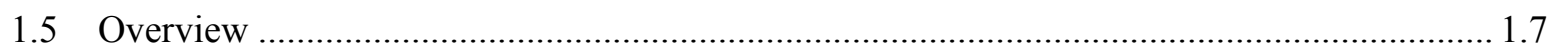

2.0 Materials Received for Testing at PNNL.......................................................................... 2.1

2.1 Alkali-Aluminosilicate Hydroceramic Cement Test Specimens ......................................... 2.1

2.2 Ceramicrete Phosphate-Bonded Ceramic Test Specimens .................................................. 2.1

2.3 DuraLith Alkali-Aluminosilicate Geopolymer Test Specimens ......................................... 2.6

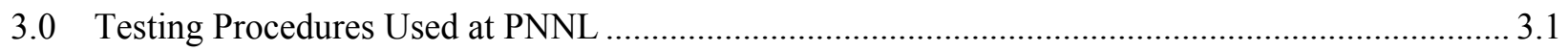

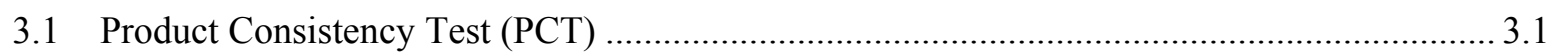

3.2 Durability by ANSI/ANS 16.1 Leachability Index Test.................................................. 3.2

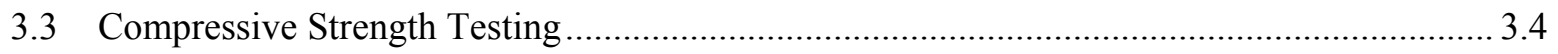

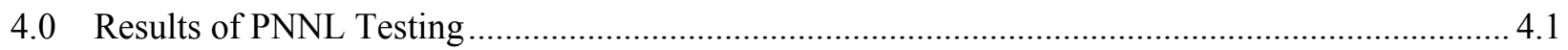

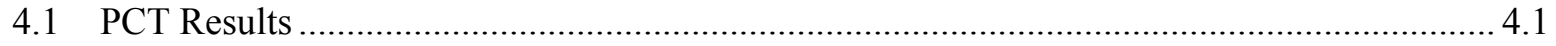

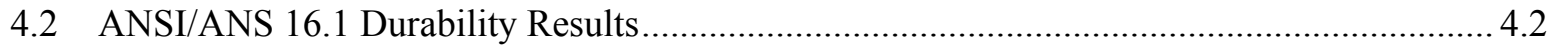

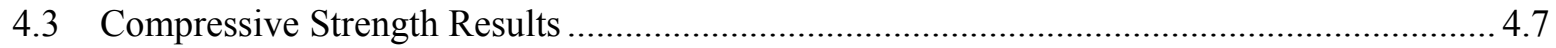

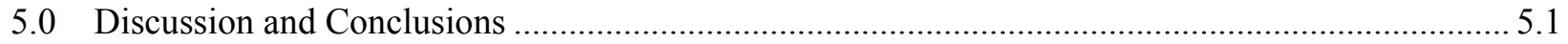

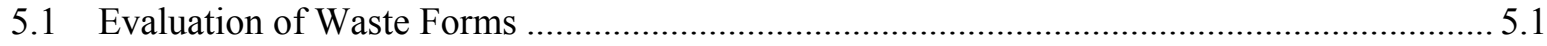

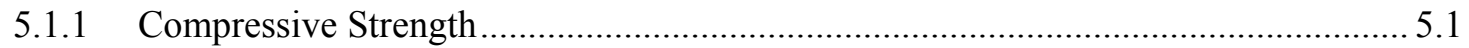

5.1.2 Toxicity Characteristic Leaching Procedure..................................................... 5.1

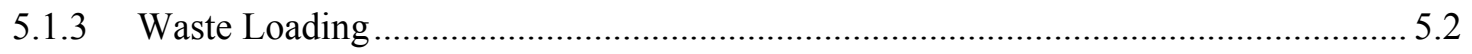

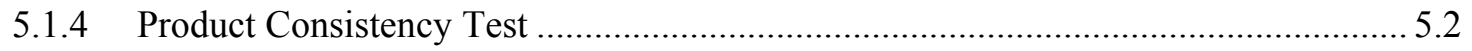

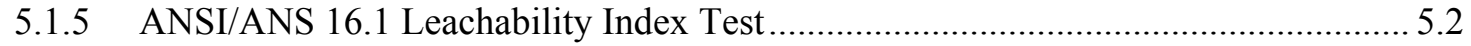




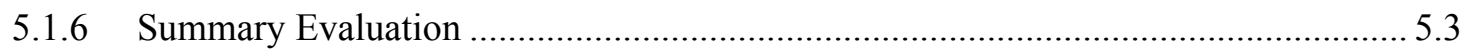

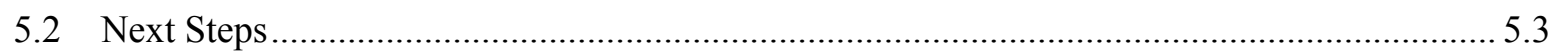

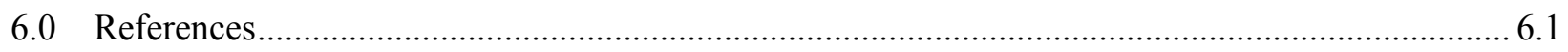

Attachment A: Evaluation Criteria For Proposals Received.............................................................. A.1

Attachment B—Noah Technologies Simulant Reports ......................................................................

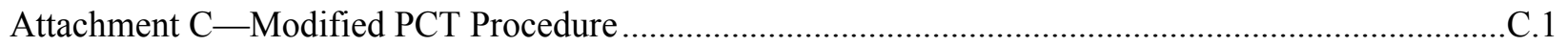

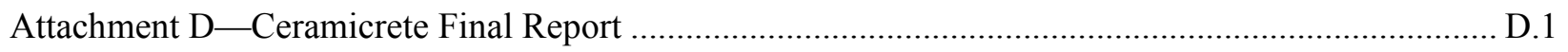

Attachment E-Hydroceramic Cement Final Report ....................................................................... 1

Attachment $\mathrm{F}$ has been compiled as Volume 2, which is limited distribution. 


\section{Figures}

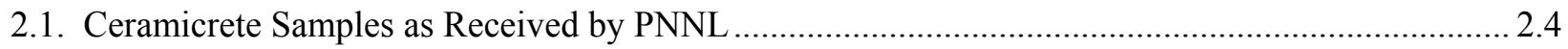

2.2. Ceramicrete Samples After Removal from Container .............................................................. 2.5

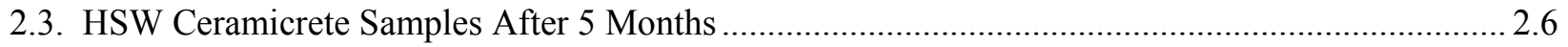

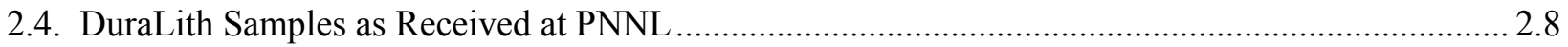

2.5. HSW DuraLith Samples as Received from VSL Showing Two Distinct Colors ............................ 2.9

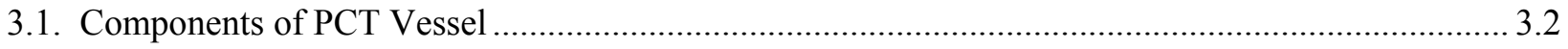

3.2. Configuration for ANS 16.1 Detachability Index Test ............................................................. 3.3

3.3. Specimen in Compression Platens, Showing Typical Failure …................................................ 3.6

4.1. Final Waste Forms After 90 Days of ANSI/ANS 16.1 Testing .................................................... 4.4

4.2. Sample TB-9R3-D-S-6 After 2 Hours of ANSI/ANS 16.1 Testing ............................................... 4.5

4.3. Comparison of Mean Compressive Strength Measurements on Waste Forms ............................... 4.8

4.4. Ceramicrete HSW Sample Compression Results .................................................................... 4.9

4.5. Ceramicrete SBW Sample Compression Results...................................................................... 4.10

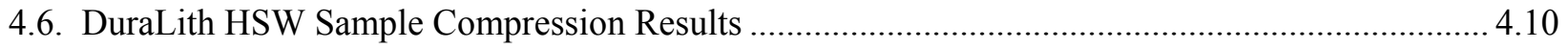

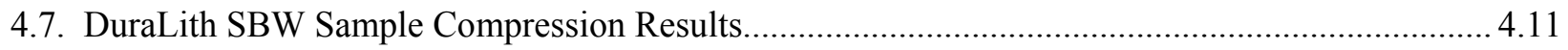

4.8. Test Specimens after Compression Testing ............................................................................ 4.12 


\section{Tables}

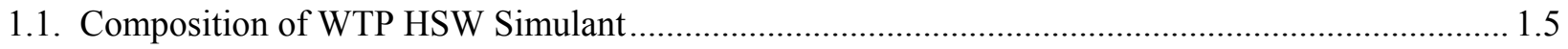

1.2. Composition of Idaho Sodium Bearing Waste Simulant ........................................................... 1.6

2.1. TCLP Test Results of Hydroceramic Cement........................................................................ 2.1

2.2. Makeup of Ceramicrete Test Waste Forms for Dewatered SBW and HSW (weight percent) .......... 2.2

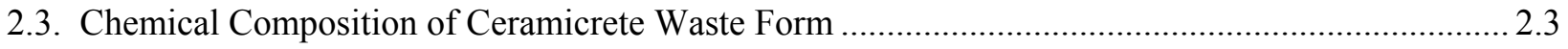

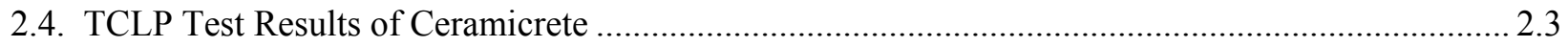

2.5. 21-Day Compressive Strength Results of Ceramicrete ............................................................... 2.4

2.6. Chemical Composition of DuraLith Waste Form ........................................................................ 2.7

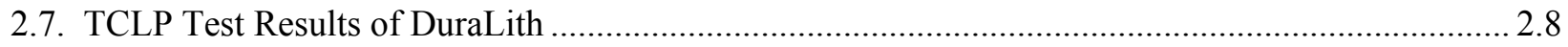

2.8. 28-Day Compressive Strength Results of DuraLith.............................................................. 2.8

3.1. Sample Irradiation Dose Rate and Exposure Time ...................................................................... 3.5

4.1. pH Results of the PCT 7-Day -100, +200 mesh Particle Size Samples .......................................... 4.1

4.2. PCT Results of the 7 Day $-100,+200$ Mesh Particle Size Samples............................................... 4.1

4.3. PCT Results of 1-Day -10, +20 mesh Particle Size Samples..................................................... 4.2

4.4. PCT Results of the 1-Day -10, +20 mesh Particle Size Samples ................................................. 4.2

4.5. $\mathrm{pH}$ of ANSI/ANS 16.1 Tests Leach Solutions Throughout the 90 Days of Testing........................ 4.3

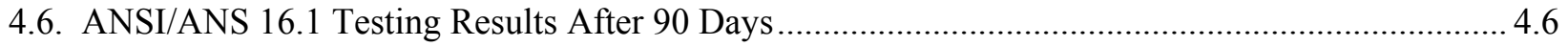

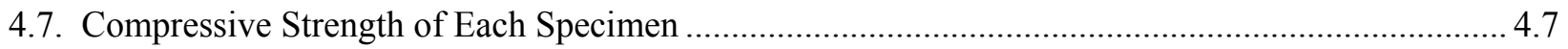




\subsection{Introduction}

The Pacific Northwest National Laboratory (PNNL) is evaluating low-temperature technologies to immobilize mixed radioactive and hazardous waste. Three waste forms - alkali-aluminosilicate hydroceramic cement, "Ceramicrete" phosphate-bonded ceramic, and "DuraLith" alkali-aluminosilicate geopolymer - were selected through a competitive solicitation for fabrication and characterization of waste-form properties. The three contractors prepared their respective waste forms using simulants provided by PNNL and characterized their waste forms with respect to the Toxicity Characteristic Leaching Procedure (TCLP) and compressive strength. The contractors sent specimens to PNNL, and PNNL then conducted durability (American National Standards Institute/American Nuclear Society [ANSI/ANS] 16.1 Leachability Index [LI] and modified Product Consistency Test [PCT]) and compressive strength testing (both irradiated and as-received samples). This report presents the results of these characterization tests.

\section{$1.1 \quad$ Background}

The United States has approximately 400 million liters (100 million gallons) of liquid high-level waste (HLW) stored in underground tanks and approximately 4400 cubic meters of solid HLW stored in bins. The current estimate of the cost of retrieving the liquid and solid wastes from the tanks and converting them into forms suitable for disposal exceeds U.S. $\$ 50$ billion. The purpose of the work reported here is to evaluate the effectiveness of low-temperature or ceramic stabilization technologies as alternatives to conventional waste-immobilization technologies, e.g., vitrification and Portland cementbased grouts. Specific target wastes for immobilization are 1) Hanford Waste Treatment and Immobilization Plant (WTP) secondary waste (HSW) and 2) Idaho Nuclear Technology and Engineering Center (INTEC) sodium bearing waste (SBW). Some of this material may be suitable for treatment and disposal by low temperature, i.e., less than $150^{\circ} \mathrm{C}\left(302^{\circ} \mathrm{F}\right)$, immobilization.

The Hanford Site has 177 underground tanks containing radioactive waste generated from the production of plutonium. The Office of River Protection's WTP is being designed and built to treat and vitrify a large portion of these wastes. The WTP will consist of three primary facilities: a pretreatment facility and two facilities for low-activity and HLW vitrification. The pretreatment facility will receive waste feed from the Hanford tank farms and separate it into two treated process streams: a high-volume, low-activity, liquid process stream stripped of most solids and high-activity radioisotopes and a much smaller volume HLW slurry containing most of the solids, high-activity radioisotopes, and long-lived isotopes. In the pretreatment facility, solids and radioisotopes will be removed from the tank waste by precipitation, filtration, and ion exchange processes to produce the low-activity waste (LAW) streams. The slurry of filtered solids will be blended with two ion exchange eluate streams containing soluble radioisotopes to produce the HLW streams. The pretreated HLW mixture will route to the High-Level Waste Vitrification Facility, and the pretreated LAW stream will route to the Low-Activity Waste Vitrification Facility. These two vitrification facilities will convert these process streams into glass, which is poured directly into stainless steel canisters.

In the Hanford WTP, ${ }^{129} \mathrm{I}$ is expected to be captured in an off-gas caustic scrubber and subsequently discharged in a secondary liquid waste bleed stream to the Liquid Effluent Retention Facility (LERF) and Effluent Treatment Facility (ETF). Rather than treating this scrubber solution in LERF and ETF, lowtemperature immobilization technologies are being considered for this aqueous liquid waste stream. 
Approximately 4.6 million liters (1.2 million gallons) of radioactive SBW are currently contained in the tank farm at the INTEC. Sodium-bearing waste is the remaining high-activity liquid waste at the INTEC that must be removed from the underground storage tanks and stabilized into a solid waste form. It was generated from sodium carbonate scrubbing of the tributyl phosphate extractant used in the separations process, from the second and third cycles of the spent nuclear fuel processing, and from decontamination of HLW facilities, It contains a small amount $(<5 \%)$ of undissolved solids. It is highly acidic ( $>2 \mathrm{M}$ acid) and relatively high in sodium and potassium content from the solutions used for decontamination. SBW is high in transuranics (TRU) and is best characterized as mixed transuranic waste.

\subsection{Waste-Form Selection}

The three waste forms evaluated as part of this low-temperature immobilization study were identified through an unrestricted solicitation that PNNL conducted on behalf of the U.S. Department of Energy (DOE). In a request for proposal issued by PNNL on September 1, 2004, proposals were solicited for demonstrations of low-temperature technologies to immobilize mixed radioactive and hazardous waste. For the purpose of the solicitation, low temperature was defined as less than $150^{\circ} \mathrm{C}\left(302^{\circ} \mathrm{F}\right)$. Alternatives to conventional waste-immobilization technologies, e.g., vitrification and Portland cement-based grouts, were specifically requested. Relatively mature technologies with the feasibility of deployment in 1 to 2 years were favored by the evaluation criteria.

Proposals received were evaluated with respect to:

- technical merit of the proposed technology

- technical approach to preparing and testing the waste forms

- capabilities and experience of the organization proposing it

- $\quad$ price.

Attachment A lists the criteria used in evaluating the proposals received.

Response to the request for proposals (RFP) was very good. Based on the evaluation criteria, the following three waste forms/organizations were selected to participate in the testing program:

- Alkali-aluminosilicate hydroceramic cement from the Diagnostic Instrumentation and Analysis Laboratory (DIAL) at Mississippi State University

- "Ceramicrete" phosphate-bonded ceramic from CH2MHILL

- "DuraLith" alkali-aluminosilicate geopolymer from The Catholic University of America Vitreous State Laboratory (VSL).

\subsubsection{Alkali-Aluminosilicate Hydroceramic Cement}

Alkali-aluminosilicate hydroceramic cements are typically formed through the reaction of clay and caustic solution at elevated temperature to form sodium aluminosilicates such as sodalites, zeolites, and feldspathoids. These aluminosilicates form cage-like structures that are capable of trapping the soluble 
components, such as sodium and cesium, in the wastes. Sodalite formed by pressing and sintering has been shown to reduce the leachability of iodide/iodate (Babad and Strachan 1980). Typically, the hydroceramic cements are formed under autoclave conditions. However, there is some evidence that the hydroceramic cements can be formed at the lower temperatures $\left(<150^{\circ} \mathrm{C}\right)$ required for this project (Siemer et al. 2002).

In the work conducted at Mississippi State University for this low-temperature immobilization study, additives including sodium hydroxide, metakaolin clay, silica, vermiculite, and sodium sulfide were added to the wastes to form the hydroceramic cements. Curing tests with the Hanford scrubber waste were conducted at room temperature and at $90^{\circ} \mathrm{C}$ for 7 days. The final DIAL report is provided in Attachment E.

\subsection{2 "Ceramicrete" Phosphate-Bonded Ceramic}

Phosphate-bonded ceramics, also known as chemically bonded phosphate ceramics (CBPC), form through the reaction of magnesium oxide with monopotassium phosphate (DOE 1999) according to the following reaction:

$$
\mathrm{MgO}+\mathrm{KH}_{2} \mathrm{PO}_{4}+5 \mathrm{H}_{2} \mathrm{O} \rightarrow \mathrm{MgKPO}_{4} \cdot 6 \mathrm{H}_{2} \mathrm{O}
$$

The reaction takes place at room temperature, although there is some heat generation from the reaction, to form a hard, insoluble ceramic. Some waste components react to form insoluble phosphates, and others are encapsulated in the matrix. The patented technology (Wagh and Singh 1997) has been licensed to treat mixed and low-level wastes and is being used for macroencapsulation and containerization of uranium. Phosphate ceramics are used for road and highway repairs, and the oil industry is testing for drilling casing and capping. The medical/dental industry is using several phosphate-ceramic formulations.

The CH2MHill/Argonne National Laboratory (ANL) team conducting this low-temperature immobilization study briefly evaluated aluminum phosphate ceramic and iron phosphate ceramic forms before settling on the more mature magnesium potassium phosphate technology. The waste-treatment process includes neutralizing the waste to a $\mathrm{pH}$ of 5; adding sodium sulfide, tin chloride, and silver zeolite to precipitate insoluble compounds of $\mathrm{Hg}$ and $\mathrm{Cr}, \mathrm{Tc}(\mathrm{Re})$, and I, respectively; evaporating water to reduce the volume; and adding the binder mix $\left(\mathrm{MgO}, \mathrm{KH}_{2} \mathrm{PO}_{4}, \mathrm{CaSiO}_{3}\right)$. As will be discussed later, neutralization to a $\mathrm{pH}$ of 4 is expected to provide a better waste form. Adding silica as wollastonite $\left(\mathrm{CaSiO}_{3}\right)$ or fly ash is expected to improve the waste-form performance. Attachment D contains the $\mathrm{CH} 2 \mathrm{MHill}$ final report on the Ceramicrete formulation and testing.

\subsection{3 "DuraLith" Alkali-Aluminosilicate Geopolymer}

Similar to alkali-aluminosilicate hydroceramic cements, geopolymers form through the reaction of an aluminosilicate material such as clay or fly ash in a caustic solution. When the reactions proceed at near ambient temperatures, polymerization takes place, forming amorphous to semi-crystalline aluminosilicate networks (Perara et al. 2005). Davidovits is attributed with the early development and formulation of geopolymers (Davidovits 1994a, 1994b, 1996), and others have conducted research on the formulation and application of geopolymers, including waste management. The specifics of the DuraLith geopolymer 
are considered confidential and proprietary to VSL and Duratek and will not be documented here. The information is reported in the VSL report submitted as part of this project (see Attachment F).

\subsection{Approach}

The general approach to evaluate the three waste forms was to have each contractor prepare specimens of their respective waste forms using the same WTP HSW and INTEC SBW simulants and then characterize the waste forms for chemical composition, TCLP, and compressive strength. The contractors then provided test specimens to PNNL for additional testing, including PCT Method B, ANSI/ANS-16.1 Leachability Index, and compressive strength before and after irradiation. Because the initial expectations were that the proposed waste forms were relatively mature technologies, the contractors were given only minimal time and budget for a few scoping/screening tests to tailor the waste forms for the waste simulants provided. An extensive waste-form development effort was not expected or desired. As will be seen in the results that follow, the waste forms would have benefited from some additional time and resources to be adapted to these waste streams.

Each contractor was required to prepare a final report describing the waste form. The test report was to describe the waste-form development and preparation, including temperatures, the results of the characterization testing (including chemical composition, waste loading, TCLP, and compressive strength), data analysis, a summary of the test methods, and a comparison of the waste-form properties to the product specifications. The report was also to describe the waste-forming technology and the concept for a processing facility to treat the wastes, including the processing steps and the final waste-form packaging. Finally, the report was to describe any issues identified in the waste-form development and characterization activities. These contractor reports are included in this report as attachments.

\subsubsection{Waste Simulants}

Two simulants were provided to the contractors for their waste-form preparation. The WTP HSW simulant represents a caustic scrubber bleed stream from the LAW vitrification off-gas process at the WTP. This caustic scrubber is downstream of the main LAW vitrification off-gas treatment system and is expected to capture volatile iodine not removed earlier in the process. Table 1.1 shows the specific composition used, which is based on flowsheet modeling. ${ }^{\text {(a) }}$ The simulant is highly alkaline with a pH of 11.5 and is based on a nominal $2 \mathrm{M}$ sodium concentration. Iodine and rhenium were included to represent the volatile iodine and technetium. The Resource Conservation and Recovery Act (RCRA) metals, Ag, $\mathrm{Cd}, \mathrm{Cr}$, and $\mathrm{Pb}$, were included in the simulant at 100 times their maximum expected concentration to increase analytical sensitivity in the TCLP test. Mercury was included at its maximum expected concentration.

Table 1.2 shows the composition of the INTEC SBW simulant. All constituent concentrations are based on tank WM-180, except $\mathrm{H}^{+}$, which was based on the average of 4-tank composition (WM-180, $187,-188,-189)$, to challenge the formulations with a more representative acid concentration. The SBW simulant was highly acidic with a $\mathrm{pH}$ of 0.5 .

(a) LA Mahoney, and RL Russell. 2004. Letter Report: Vitrification Offgas Caustic Scrubber Secondary Waste Simulant Formulation, PNNL-14582 Rev 1, Pacific Northwest National Laboratory, Richland, WA. 
PNNL contracted with Noah Technologies to prepare the waste simulants. Noah Technologies prepared a single large batch of each simulant and, after confirmatory testing, shipped the simulants directly to the three contractors. Each contractor was provided 75 liters of the WTP HSW simulant and 38 liters of the INTEC SBW simulant. See Attachment B for the Noah Technologies reports on the simulant preparation. The contractors were provided the recipes for the simulants so that they could prepare simulants for their scoping/screening testing. They were expected to prepare the final waste forms for testing from the Noah Technologies-prepared simulants.

Table 1.1. Composition of WTP HSW Simulant

\begin{tabular}{||c|c|c|c||}
\hline \hline Element & Target (moles/L) & Target (g/L) & Noah Data (g/L) \\
\hline $\mathrm{Na}$ & 2.0 & 46 & 45.17 \\
\hline $\mathrm{Al}$ & 0.011 & 0.299 & 0.318 \\
\hline $\mathrm{Cr}$ & $2.8 \mathrm{E}-04$ & 0.0145 & 0.0149 \\
\hline $\mathrm{Ag}$ & $2.2 \mathrm{E}-04$ & 0.0237 & 0.0235 \\
\hline $\mathrm{Cd}$ & $1.4 \mathrm{E}-05$ & 0.00157 & 0.00157 \\
\hline $\mathrm{Re}(\mathrm{Tc})$ & $6.00 \mathrm{E}-07$ & $1.12 \mathrm{E}-04$ & $1.25 \mathrm{E}-04^{(\mathrm{a})}$ \\
\hline $\mathrm{I}$ & $2.90 \mathrm{E}-06$ & $3.68 \mathrm{E}-04$ & $\mathrm{NA}$ \\
\hline $\mathrm{Hg}$ & $2.4 \mathrm{E}-06$ & $4.81 \mathrm{E}-04$ & $4.15 \mathrm{E}-04$ \\
\hline $\mathrm{Pb}$ & $1.5 \mathrm{E}-04$ & 0.031 & 0.0323 \\
\hline $\mathrm{CO}_{3}{ }^{-}$ & 0.96 & 57.6 & 60 \\
\hline $\mathrm{NO}_{3}{ }^{-}$ & 0.018 & 1.116 & 1.12 \\
\hline $\mathrm{OH}^{-}$ & 0.094 & 1.598 & 1.6 \\
\hline $\mathrm{TOC}$ & 0.18 & 13.86 & 13.86 \\
\hline (a) Noah did not analyze. This is Argonne National \\
$\mathrm{L}^{-}$
\end{tabular}

\subsubsection{Waste-Form Characterization}

To be acceptable for disposal, HLW and LAW waste forms must have characteristics documented and must meet specific performance requirements. For this initial evaluation of low-temperature waste forms, chemical composition, TCLP, compressive strength, PCT, and ANS-16.1 Leachability Index testing were chosen to characterize the waste forms. The characterization methods were selected before the solicitation process was started and as such, before the waste forms to be tested were known.

Waste-disposal criteria typically require reporting the chemical composition of the waste forms. The contractors were therefore required to report the chemical compositions. The TCLP is required to address the disposal of hazardous metals in the wastes (40 CFR 268; EPA 1997).

Low-level waste forms must meet a compressive strength requirement to prevent subsidence of the disposal facility. Proposed stabilized secondary waste-form requirements at the time of the request for proposals required that the mean compressive strength of the waste forms shall be at least $3.45 \mathrm{MPa}$ (500 psi) when testing in accordance with ASTM C-39/C-39M-99. Further, because some materials are susceptible to structural damage from self-irradiation, changes in compressive strengths of the waste form after irradiation to a dose of 1.0E8 rad should not be less than 75 percent of the initial compressive 
strength. Changes in compressive strength due to thermal cycling or biological activity may need to be determined in the future, depending on the disposal-facility requirements.

Table 1.2. Composition of Idaho Sodium Bearing Waste Simulant

\begin{tabular}{|c|c|c|c|}
\hline Element & Target (moles/L) & Target $(\mathrm{g} / \mathrm{L})$ & Noah Data (g/L) \\
\hline $\mathrm{Na}$ & 1.88 & 43.24 & 43.2 \\
\hline $\mathrm{Al}$ & 0.575 & 15.5 & 17.8 \\
\hline $\mathrm{Ca}$ & 0.0366 & 1.464 & 1.46 \\
\hline B & 0.0102 & 0.11 & 0.11 \\
\hline $\mathrm{Mg}$ & 0.0108 & 0.26 & 0.26 \\
\hline $\mathrm{K}$ & 0.175 & 6.825 & 6.8 \\
\hline $\mathrm{Cr}$ & 0.0033 & 0.172 & 0.172 \\
\hline $\mathrm{Mn}$ & 0.0126 & 0.69 & 0.69 \\
\hline $\mathrm{Fe}$ & 0.0178 & 0.993 & 0.99 \\
\hline $\mathrm{Cd}$ & 0.0007 & 0.0786 & 0.078 \\
\hline Cs & $7.99 \mathrm{E}-10$ & $1.1 \mathrm{E}-07$ & $2.34 \mathrm{E}-05^{(\mathrm{a})}$ \\
\hline $\mathrm{Ce}$ & $5.30 \mathrm{E}-06$ & $7.43 \mathrm{E}-04$ & $7.82 \mathrm{E}-04^{(\mathrm{a})}$ \\
\hline $\mathrm{Hg}$ & 0.002 & 0.401 & 0.4 \\
\hline $\mathrm{Pb}$ & 0.0013 & 0.269 & 0.27 \\
\hline $\operatorname{Re}(\mathrm{Tc})$ & $3.13 \mathrm{E}-06$ & $5.83 \mathrm{E}-04$ & $6.37 \mathrm{E}-04^{(\mathrm{a})}$ \\
\hline I & $5.66 \mathrm{E}-05$ & $7.18 \mathrm{E}-03$ & $3.43 \mathrm{E}-03^{(\mathrm{a})}$ \\
\hline $\mathrm{SO}_{4}^{-}$ & 0.0491 & 4.71 & $5.15^{(\mathrm{a})}$ \\
\hline $\mathrm{H}_{2} \mathrm{O}$ & 45.1 & 812.7 & 812 \\
\hline $\mathrm{NO}_{3}^{-}$ & 4.91 & 304.4 & $269^{(\mathrm{a})}$ \\
\hline $\mathrm{F}$ & 0.0403 & 0.765 & $0.83^{(a)}$ \\
\hline $\mathrm{Cl}$ & 0.0285 & 1.009 & $1.15^{(\mathrm{a})}$ \\
\hline $\mathrm{H}$ & 1.87 & 1.87 & NM \\
\hline \multicolumn{4}{|c|}{$\begin{array}{l}\text { (a) Noah did not analyze. This is Argonne National } \\
\text { Laboratory's analytical result. } \\
\text { NM = not measured }\end{array}$} \\
\hline
\end{tabular}

The ANS-16.1 Leachability Index is used to characterize the release of radionuclides from low-level waste forms such as cements where diffusion is assumed to limit the release of contaminants from the waste form (ANSI/ANS 1986). Proposed stabilized secondary-waste-form requirements at the time of the request for proposals required that the waste form have a sodium leachability index greater than 6.0 when tested for 90 days. Leachability index targets of 11.0 for ${ }^{129} \mathrm{I}$ and 9.0 for ${ }^{99} \mathrm{Tc}$ were desired; non radioactive stand-in elements are used-I and Re, respectively. The PCT was developed specifically for glass waste forms (ASTM 2002). No performance requirements have been established for non-glass waste forms in the PCT. The PCT and ANS-16.1 test methods tend to be waste-form specific, and their ability to characterize the selected specific waste forms remains to be demonstrated. They are included in the testing here to obtain an initial indication of the waste-form performance.

\subsection{Quality Assurance}

The work performed at PNNL was conducted under PNNL's Standards Based Management System (SBMS). All the PNNL tests were proof-of-principle in nature and were performed under the guidance of 
PNNL's SBMS. All laboratory data, general observations, and details of the activities performed in this task were recorded on data entry sheets. PNNL standard laboratory practices were followed throughout the testing.

Records for this task were the data entry sheets and any laboratory record book (LRB) pages used to record data and test information. These include instrument calibrations, test set up and standards, data logging, calculations, and review comments and signatures. Copies of all test records will be provided to the project records custodian for storage.

As part of their contracts, the three waste-form contractors were required to use a management system that verifies the proper control of the testing to be performed. The management system shall include the following: qualified personnel/processes, calibrated equipment traceable to a national standard, document control, written procedures, and control of nonconforming items. Before awarding a contract, PNNL conducted desk audits of the three contractors. Their specific implementation is described in their final reports.

\subsection{Overview}

Section 2 of this report describes the test specimens received at PNNL from the different contractors for testing. The testing procedures used for the durability and compressive strength tests performed at PNNL are described in Section 3. Section 4 presents the results of the TCLP and compressive-strength testing performed by the contractors as well as the durability and compressive-strength testing at PNNL, and Section 5 summarizes the findings and provides the recommended steps forward. Section 6 provides a list of the references used.

The attachments provide supplemental information to the report. However, Attachment $F$ is not publicly available and is for limited distribution only because it contains proprietary information. 


\subsection{Materials Received for Testing at PNNL}

PNNL received test specimens of the Ceramicrete phosphate-bonded ceramic, DuraLith alkalialuminosilicate geopolymer, and the alkali-aluminosilicate hydroceramic cements from $\mathrm{CH} 2 \mathrm{MHill}$, The Catholic University of America VSL, and DIAL, respectively. This section will discuss the materials PNNL received for testing in greater detail.

\subsection{Alkali-Aluminosilicate Hydroceramic Cement Test Specimens}

DIAL provided test specimens of the alkali-aluminosilicate hydroceramic cement waste form for the SBW simulant. The ingredients of this cement are water, sodium hydroxide, metakaolin, vermiculite (optional), silica (optional), sodium sulfide, and waste. They found a formulation for the INTEC SBW simulant in a hydroceramic cement form that met the minimum compressive strength requirements of $3.45 \mathrm{MPa}$ (500 psi) in scoping tests but were unable reproduce their results later. They also performed TCLP testing on this formulation and found that it passed $\mathrm{Cr}$ and Ni Universal Treatment Standards (UTS) (40 CFR 268.48) but failed Cd and Hg UTS limits (see Table 2.1). A hydroceramic cement formulation for the WTP HSW simulant was not found. Therefore, hydroceramic cement specimens from DIAL were not tested at PNNL. See Attachment E for the final report on this technology.

Table 2.1. TCLP Test Results of Hydroceramic Cement

\begin{tabular}{|c|c|c||}
\hline Constituent & $\begin{array}{c}\text { SBW Leachate } \\
(\boldsymbol{\mu g} / \mathbf{L})\end{array}$ & $\begin{array}{c}\text { UTS Limit } \\
(\boldsymbol{\mu g} / \mathbf{L})\end{array}$ \\
\hline $\mathrm{Cr}$ & 3 & 600 \\
\hline $\mathrm{Cd}$ & 589 & 110 \\
\hline $\mathrm{Ni}$ & 65 & 1100 \\
\hline $\mathrm{Hg}$ & 124 & 25 \\
\hline \multicolumn{2}{|c|}{ (a) Ref. Code of Federal Regulations 40 CFR Part 268.48. } \\
\hline
\end{tabular}

\subsection{Ceramicrete Phosphate-Bonded Ceramic Test Specimens}

The CH2MHill test specimens were a phosphate-bonded ceramic composed of magnesium oxide, potassium acid phosphate, ash, water, and waste. They prepared test specimens of their selected standard magnesium potassium phosphate $\left(\mathrm{Mg}-\mathrm{K}-\mathrm{PO}_{4}\right)$ system known as Ceramicrete with the HSW and the SBW simulants for testing at PNNL.

A large number of cylindrical samples were produced for testing. The specimens received at PNNL for testing were 2-inch-diameter and 4-inch-length cylinders. These were prepared individually from the waste simulants that were "as-received" rather than going through an evaporation step to remove some of the water to achieve a higher waste loading. The HSW and SBW simulants were partially neutralized to a $\mathrm{pH}$ of 5 with $\mathrm{H}_{3} \mathrm{PO}_{4}$ and $\mathrm{NaOH}$, respectively. Small amounts of stabilizer additives were then added to precipitate insoluble compounds of $\mathrm{Hg}, \mathrm{Cr}, \mathrm{Tc}(\mathrm{Re})$, and I in preparation for subsequent microencapsulation in the ceramic matrix. Then some water was evaporated at $\sim 65^{\circ} \mathrm{C}$ to reduce the volume. Ceramicrete binder mix $\left(\mathrm{MgO}, \mathrm{KH}_{2} \mathrm{PO}_{4}\right.$, and $\left.\mathrm{CaSiO}_{3}\right)$ was added and stirred to effect reactions 
that convert waste constituents to insoluble compounds and ceramics, produce a ceramic matrix, and microencapsulate constituents. Slurry was poured into testing forms and cured for 7 to 21 days. Table 2.2 shows the makeup of the samples for the different simulants. The waste loading in the HSW samples was comparatively lower than that in the SBW samples.

Table 2.2. Makeup of Ceramicrete Test Waste Forms for Dewatered SBW and HSW (weight percent)

\begin{tabular}{|c|c|c|c|c|c|c|c|}
\hline $\begin{array}{l}\text { Waste } \\
\text { Stream }\end{array}$ & $\begin{array}{c}\text { Neutralizer } \\
\text { Additive }\end{array}$ & Stabilizer Additives & $\begin{array}{l}\text { Stabilized } \\
\text { Element }\end{array}$ & MgO & $\mathrm{KH}_{2} \mathrm{PO}_{4}$ & $\mathrm{CaSiO}_{3}$ & $\begin{array}{l}\text { Dewatered } \\
\text { Waste } \\
\text { Loading } \\
\text { (wet basis) }\end{array}$ \\
\hline SBW & $\mathrm{NaOH}=2.2$ & $\begin{array}{l}\text { Ag-Zeolite }=1.06 \\
\mathrm{Na}_{2} \mathrm{~S}=0.42 \\
\mathrm{SnCl}_{2}=0.42\end{array}$ & $\begin{array}{c}\mathrm{I} \\
\mathrm{Hg} \\
\mathrm{Re}\end{array}$ & 9.3 & 27.8 & 11.4 & 47.4 \\
\hline HSW & $\mathrm{H}_{3} \mathrm{PO}_{4}=10.1$ & $\begin{array}{l}\text { Ag-Zeolite }=1.2 \\
\mathrm{SnCl}_{2}=0.47\end{array}$ & $\begin{array}{c}\mathrm{I} \\
\mathrm{Re}\end{array}$ & 12.0 & 35.9 & 14.4 & 25.8 \\
\hline
\end{tabular}

Table 2.3 shows the chemical composition of the Ceramicrete waste forms sent to PNNL for testing. The remaining mass balance is assumed to be oxygen that was not taken into account here. Refer to Attachment D for more chemical composition information and the final report on this technology.

CH2M Hill also performed TCLP and compressive strength testing on their Ceramicrete test specimens before sending them to PNNL. Table 2.4 shows the results they obtained from the TCLP testing. The reported results were below the maximum concentrations allowed per the UTS in $40 \mathrm{CFR}$ 268.48. Table 2.5 shows the results of the compressive strength testing on the as-prepared specimens, which exceed the minimum $3.45 \mathrm{MPa}$ (500 psi) requirement. Compressive strengths after freeze-thaw cycling in accordance with ASTM-B553 were also reported. The compressive strengths after the cycling averaged 15.4 MPa (2230 psi) for the SBW waste form and 14.2 MPa (2057 psi) for the HSW waste form, decreases of approximately $50 \%$. Densities were $2.02 \mathrm{~g} / \mathrm{cm}^{3}$ and $2.06 \mathrm{~g} / \mathrm{cm}^{3}$ for the SBW and HSW waste forms, respectively. Waste loading for the SBW was $23 \%$ on a dry basis or $47 \%$, including the water in the waste. For the HSW, waste loading was $8 \%$ on a dry basis or $26 \%$ on a wet basis.

PNNL received 40 test specimens from ANL on October 28, 2005. There were 20 test specimens for each waste stream (SBW and HSW). The specimens were contained in a $5.1 \times 10.2 \mathrm{~cm}(2 \times 4 \mathrm{inch})$ container that was used to shape the samples (see Figure 2.1). The specimens were clearly labeled. Instructions were received by e-mail to hold some of the samples for several additional weeks to complete the curing process and to cut the samples from their containers when ready for use. Both of these instructions were followed. When the samples were extracted from the containers, they were easily removed and in excellent shape; the walls and bottom of the specimens were very smooth, but some had voids from trapped bubbles or gas generation (see Figure 2.2). 
Table 2.3. Chemical Composition of Ceramicrete Waste Form

\begin{tabular}{||l|c|c||}
\hline Constituent & $\begin{array}{c}\text { HSW } \\
\text { (wt\%) }\end{array}$ & $\begin{array}{c}\text { SBW } \\
\text { (wt\%) }\end{array}$ \\
\hline $\mathrm{Ag}$ & 0.0018 & $2.74 \mathrm{E}-06$ \\
\hline $\mathrm{Al}$ & 0.009 & 1.19 \\
\hline $\mathrm{B}$ & $2.62 \mathrm{E}-05$ & 0.0075 \\
\hline $\mathrm{Ca}$ & 5.06 & 4.08 \\
\hline $\mathrm{Cd}$ & $2.89 \mathrm{E}-05$ & 0.0047 \\
\hline $\mathrm{Ce}$ & $1.50 \mathrm{E}-07$ & $4.98 \mathrm{E}-05$ \\
\hline $\mathrm{Cl}$ & 0.178 & 0.230 \\
\hline $\mathrm{CO} 3$ & 4.40 & -- \\
\hline $\mathrm{Cr}$ & $4.56 \mathrm{E}-05$ & 0.0105 \\
\hline $\mathrm{Cs}$ & $1.25 \mathrm{E}-06$ & $1.49 \mathrm{E}-06$ \\
\hline $\mathrm{F}$ & -- & 0.0529 \\
\hline $\mathrm{Fe}$ & $4.61 \mathrm{E}-05$ & 0.0641 \\
\hline $\mathrm{Hg}$ & $6.45 \mathrm{E}-06$ & 0.0188 \\
\hline $\mathrm{I}$ & $2.70 \mathrm{E}-05$ & $2.18 \mathrm{E}-04$ \\
\hline $\mathrm{K}$ & 10.5 & 8.49 \\
\hline $\mathrm{Mg}$ & 6.89 & 5.63 \\
\hline $\mathrm{Mn}$ & -- & 0.0415 \\
\hline $\mathrm{Na}$ & 3.57 & 4.74 \\
\hline $\mathrm{NO}{ }_{3}$ & 0.114 & 17.1 \\
\hline $\mathrm{Pb}$ & 0.0017 & 0.0171 \\
\hline $\mathrm{P}$ & 11.6 & 6.37 \\
\hline $\mathrm{Re}$ & $9.14 \mathrm{E}-06$ & $4.05 \mathrm{E}-05$ \\
\hline $\mathrm{S}$ & -- & 0.282 \\
\hline $\mathrm{Si}$ & 3.55 & 2.77 \\
\hline $\mathrm{Sn}$ & 0.299 & 0.263 \\
\hline $\mathrm{TOC}$ & 1.02 & --- \\
\hline $\mathrm{H}{ }_{2} \mathrm{O}$ & 14.9 & 22.0 \\
\hline $\mathrm{Total}$ & 62.14 & 73.38 \\
\hline & & \\
\hline
\end{tabular}

Table 2.4. TCLP Test Results of Ceramicrete

\begin{tabular}{|c|c|c|c||}
\hline Constituent & $\begin{array}{c}\text { SBW Leachate } \\
(\boldsymbol{\mu g} / \mathbf{L})\end{array}$ & $\begin{array}{c}\text { HSW Leachate } \\
(\boldsymbol{\mu g} / \mathbf{L})\end{array}$ & $\begin{array}{c}\text { UTS Limit }^{(\mathbf{a})} \\
(\boldsymbol{\mu g} / \mathbf{L})\end{array}$ \\
\hline $\mathrm{Cr}$ & $<1.82$ & 53.3 & 600 \\
\hline $\mathrm{Cd}$ & $<0.28$ & $<0.28$ & 110 \\
\hline $\mathrm{Ag}$ & 3.45 & 7.79 & 140 \\
\hline $\mathrm{Hg}$ & $<7.66$ & $<7.66$ & 25 \\
\hline $\mathrm{Pb}$ & 1.47 & 9.64 & 750 \\
\hline (a) Ref. Code of Federal Regulations 40 CFR Part 268.48 \\
\hline
\end{tabular}


Table 2.5. 21-Day Compressive Strength Results of Ceramicrete

\begin{tabular}{|c|c|c|c|c|}
\hline Waste & Strength (psi) & Strength (psi) & Strength (psi) & Mean \\
\hline SBW & 4408 & 4655 & 4748 & $4603 \mathrm{psi}(31.7 \mathrm{MPa})$ \\
\hline HSW & 3956 & 4114 & 4158 & $4076 \mathrm{psi}(28.1 \mathrm{MPa})$ \\
\hline
\end{tabular}

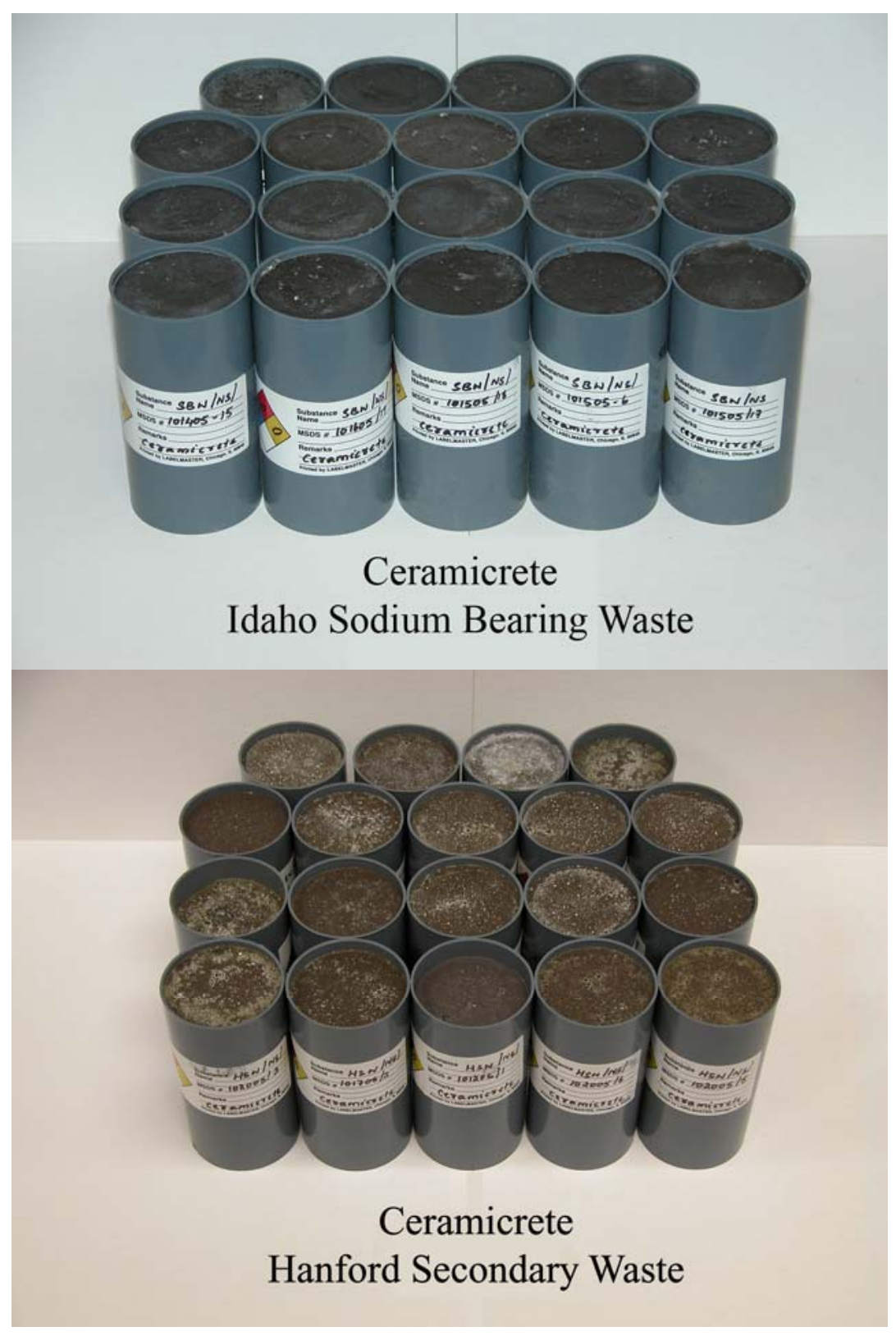

Figure 2.1. Ceramicrete Samples as Received by PNNL 


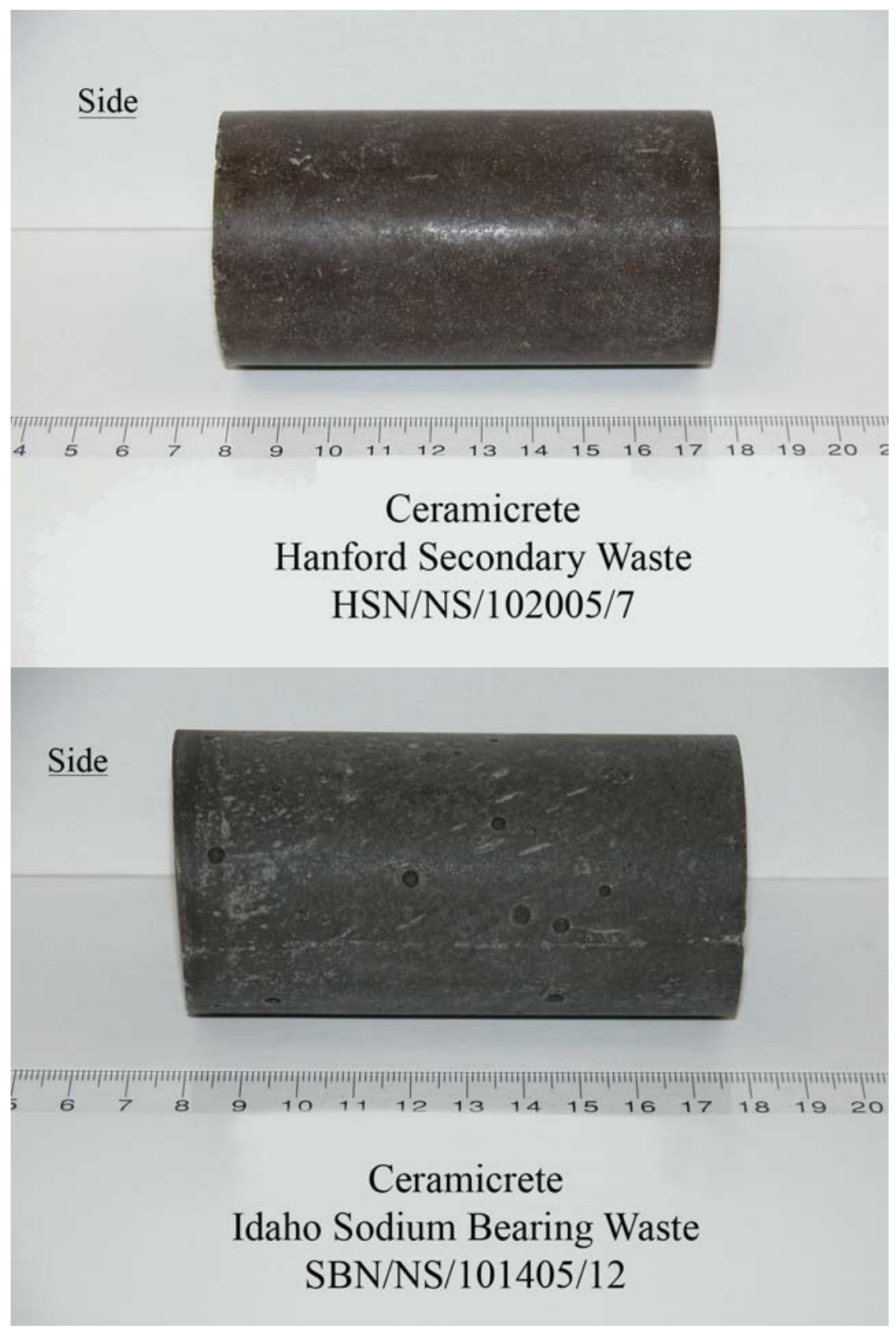

Figure 2.2. Ceramicrete Samples After Removal from Container

After 5 months, the Ceramicrete specimens containing the HSW that were not used in PNNL testing changed physically. Some shrinkage occurred as the samples pulled away from the containers into which they were poured, creating a gap between the container and the specimen that was not present when the specimens first arrived (see Figure 2.3). Also, at the top of the specimens, small cracks are visible that were not present when the specimens arrived. These cracks are observed near the center of the specimens and, in some specimens, extend to the outside edges (Figure 2.3). The Ceramicrete specimens containing the SBW appeared to be unchanged during this 5-month period. 


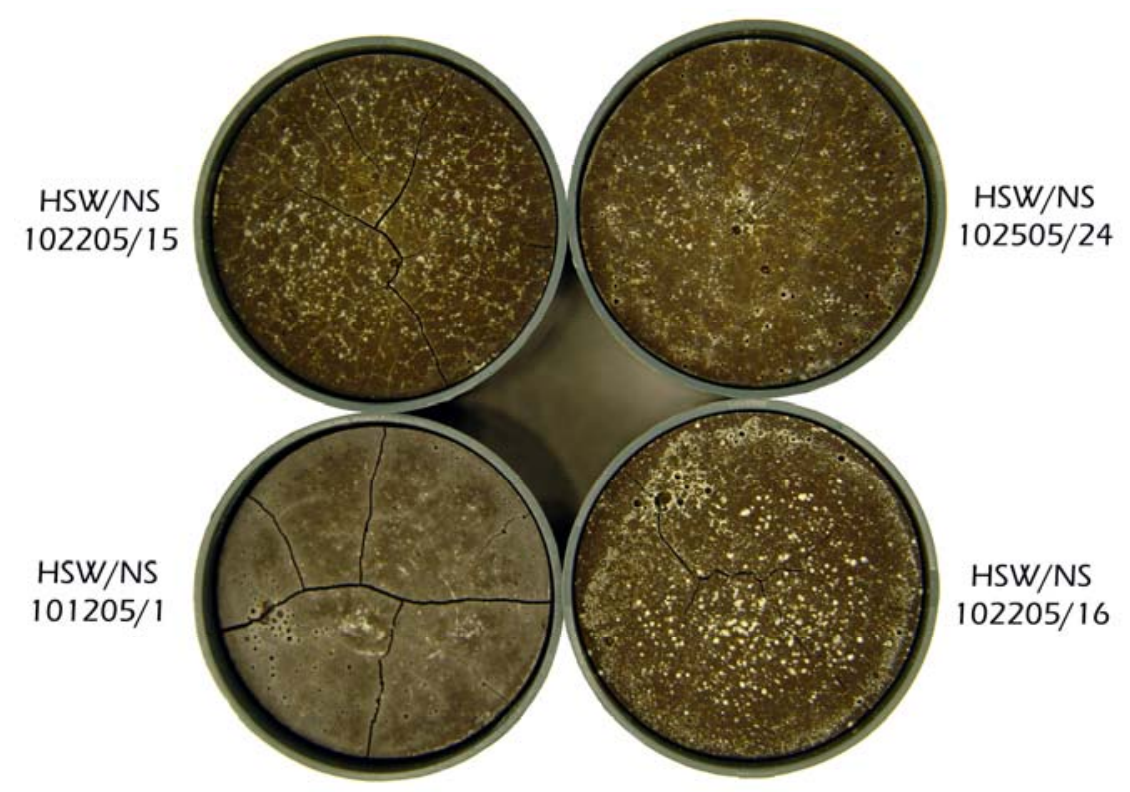

Figure 2.3. HSW Ceramicrete Samples After 5 Months

\subsection{DuraLith Alkali-Aluminosilicate Geopolymer Test Specimens}

The "DuraLith" alkali-aluminosilicate geopolymer specimens were prepared from a VSL proprietary blend of binder constituents and additives and the supplied waste simulants. To increase waste loading, some water was removed from the HSW simulant before preparing the waste forms. Water was added to the SBW before making the final waste form. The HSW simulant test specimens and the INTEC SBW simulant test specimens were cured for 28 days before being sent to PNNL for testing. Table 2.6 shows the chemical composition of the DuraLith waste forms sent to PNNL for testing. Refer to Attachment F for more chemical composition information and the VSL final report on this technology.

VSL conducted compressive-strength testing and TCLP on their DuraLith test specimens before sending them to PNNL. Table 2.7 shows the results they obtained from the TCLP testing, and Table 2.8 shows the results of the compressive strength testing. The test specimens met the criteria in both of these tests. The density of the final HSW product was approximately $1.76 \mathrm{~g} / \mathrm{cm}^{3}$. Waste loading for the HSW was $7.69 \%$ waste solids in dry product or $31.5 \%$, including the water in the waste. The density of the final SBW product was approximately $1.86 \mathrm{~g} / \mathrm{cm}^{3}$. Waste loading for the SBW was $9 \%$ waste solids in dry product or $29.4 \%$, including the water in the waste.

Twenty test specimens of the HSW were received on November 14, 2005, and another 20 test specimens of the SBW were received on November 23, 2005, from VSL. The samples were received in plastic, sealable sandwich bags wrapped in cardboard and tissue paper with paper labels taped to each sample. Samples were 2-inch-diameter and 4-inch-long cylinders. The labels were removed from the surface of the samples, but adhesive from the tape stuck to the sample. The adhesive was then removed with ethanol. Figure 2.4 shows the samples as they were received. 
Table 2.6. Chemical Composition of DuraLith Waste Form

\begin{tabular}{|l|c|c||}
\hline Constituent & $\begin{array}{c}\text { HSW } \\
\text { (wt } \%)\end{array}$ & $\begin{array}{c}\text { SBW } \\
\text { (wt } \%)\end{array}$ \\
\hline $\mathrm{Ag}$ & 0.022 & 0.032 \\
\hline $\mathrm{Al}$ & 6.51 & 6.32 \\
\hline $\mathrm{B}$ & -- & 0.002 \\
\hline $\mathrm{Ca}$ & 12.35 & 16.83 \\
\hline $\mathrm{Cd}$ & $7.80 \mathrm{E}-05$ & 0.0014 \\
\hline $\mathrm{Ce}$ & -- & $1.35 \mathrm{E}-05$ \\
\hline $\mathrm{Cl}$ & 0.0106 & 0.0315 \\
\hline $\mathrm{CO}{ }_{3}$ & 2.90 & -- \\
\hline $\mathrm{Cr}$ & $7.21 \mathrm{E}-04$ & 0.0031 \\
\hline $\mathrm{Cs}$ & -- & $1.93 \mathrm{E}-09$ \\
\hline $\mathrm{F}$ & -- & 0.0139 \\
\hline $\mathrm{Fe}$ & 0.26 & 0.52 \\
\hline $\mathrm{H}$ & -- & 0.0367 \\
\hline $\mathrm{Hg}$ & $2.39 \mathrm{E}-05$ & 0.0073 \\
\hline $\mathrm{I}$ & $1.82 \mathrm{E}-05$ & $1.31 \mathrm{E}-04$ \\
\hline $\mathrm{K}$ & 7.59 & 11.00 \\
\hline $\mathrm{Mg}$ & 3.42 & 3.22 \\
\hline $\mathrm{Mn}$ & -- & 0.0126 \\
\hline $\mathrm{Na}$ & 3.11 & 1.38 \\
\hline $\mathrm{NH}_{3}$ & 0.102 & -- \\
\hline $\mathrm{NO}{ }_{3}$ & 0.0801 & 5.57 \\
\hline $\mathrm{OH}$ & 0.0792 & -- \\
\hline $\mathrm{Pb}$ & 0.0015 & 0.0049 \\
\hline $\mathrm{Re}$ & $5.53 \mathrm{E}-06$ & $1.06 \mathrm{E}-05$ \\
\hline $\mathrm{Si}$ & 19.17 & 18.26 \\
\hline $\mathrm{Sn}$ & 0.023 & 0.032 \\
\hline $\mathrm{SO}{ }_{3}$ & 1.39 & 1.67 \\
\hline $\mathrm{Ti}$ & 0.25 & 0.24 \\
\hline $\mathrm{TOC}$ & 0.107 & 0.0519 \\
\hline $\mathrm{H}_{2} \mathrm{O}$ & 40.2 & 14.8 \\
\hline $\mathrm{Total}$ & 97.58 & 80.00 \\
\hline
\end{tabular}


Table 2.7. TCLP Test Results of DuraLith

\begin{tabular}{|c|c|c|c||}
\hline Constituent & $\begin{array}{c}\text { In SBW Leachate } \\
(\boldsymbol{\mu g} / \mathbf{L})\end{array}$ & $\begin{array}{c}\text { In HSW Leachate } \\
(\boldsymbol{\mu g} / \mathbf{L})\end{array}$ & $\begin{array}{c}\text { UTS Limit }^{(\mathbf{a})} \\
(\boldsymbol{\mu} \mathbf{g} / \mathbf{L})\end{array}$ \\
\hline $\mathrm{Cr}$ & 40 & 10 & 600 \\
\hline $\mathrm{Cd}$ & $<30$ & $<30$ & 110 \\
\hline $\mathrm{Ag}$ & $<70$ & $<70$ & 140 \\
\hline $\mathrm{Hg}$ & $<10$ & $<10$ & 25 \\
\hline $\mathrm{Pb}$ & $<100$ & $<100$ & 750 \\
\hline (a) Ref. Code of Federal Regulations 40 CFR Part 268.48 \\
\hline \multicolumn{4}{|r}{} \\
\hline
\end{tabular}

Table 2.8. 28-Day Compressive Strength Results of DuraLith

\begin{tabular}{|c|c|c|c||}
\hline Waste & Strength (MPa) & Strength (MPa) & Mean (MPa) \\
\hline SBW & 43 & 48 & 45.5 \\
\hline HSW & 40 & 41 & 40.5 \\
\hline
\end{tabular}

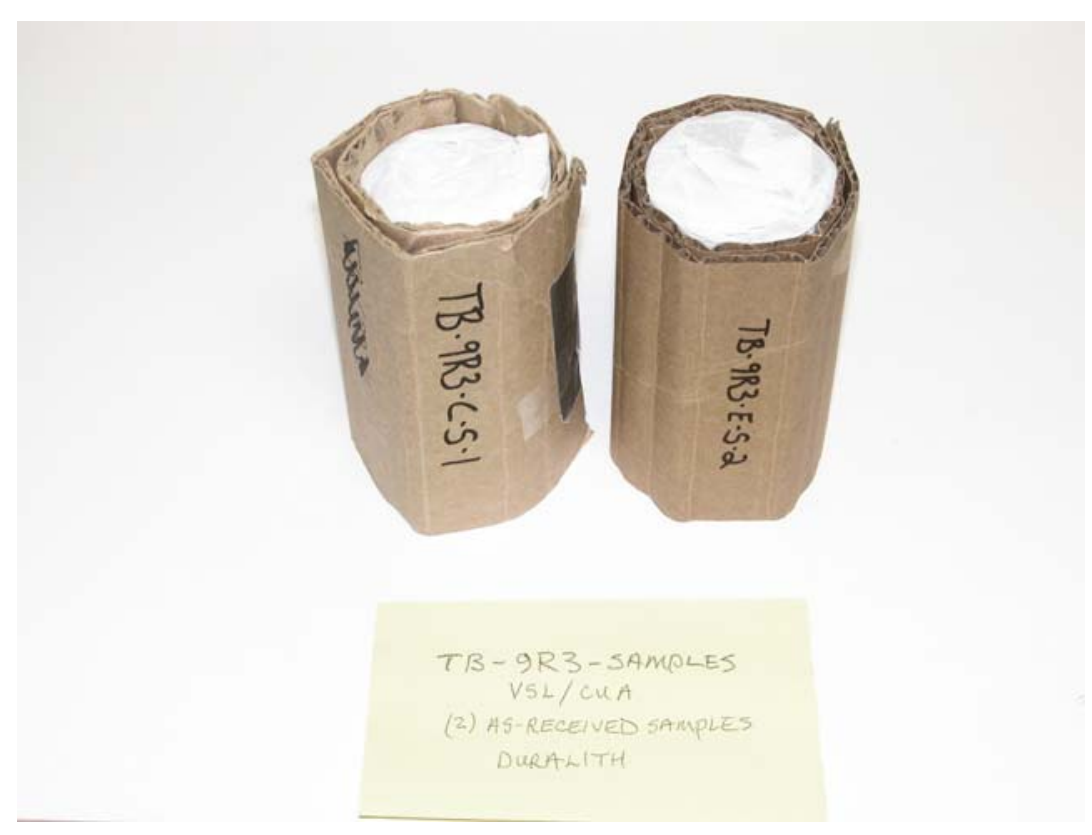

Figure 2.4. DuraLith Samples as Received at PNNL

There were two distinct colors of the as-received DuraLith waste-form specimens made with the Hanford secondary waste; approximately half the specimens were a light gray color, and the remaining were a dark gray color (Figure 2.5). When asked about the color differences, VSL speculated that the color differences were most likely due to differences in impurities between industrial and reagent grades in one of the batching chemicals. 


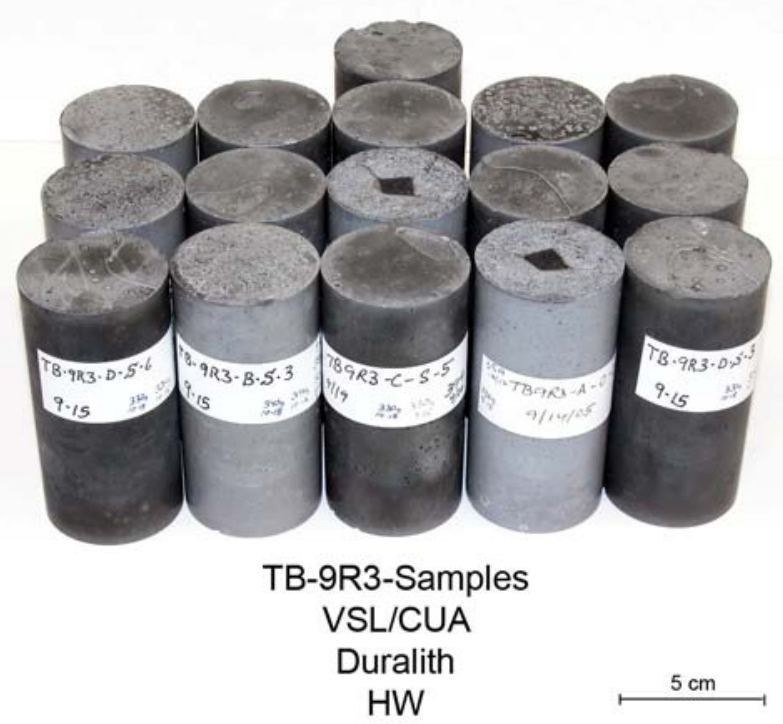

Figure 2.5. HSW DuraLith Samples as Received from VSL Showing Two Distinct Colors

The unused DuraLith specimens were examined at the completion of testing (a 5-month time period). Neither the HSW nor the INTEC SBW waste forms had cracks in the specimens. Shrinkage was not determined because initial diameters of these specimens were not measured. 


\subsection{Testing Procedures Used at PNNL}

This section presents the procedures used at PNNL to test the durability (modified PCT and ANSI/ANS 16.1 Leachability Index) and compressive strength (both irradiated and as-received samples) of low-temperature waste forms supplied by the participating contractors.

\subsection{Product Consistency Test (PCT)}

The ultimate objective for immobilization is to convert the waste into a stable waste form that will resist the release of contaminants into the environment. This resistance of the waste form to release deleterious environmental components is defined by measuring its chemical durability, i.e., the resistance of the waste form to react with the aqueous environment expected at the disposal site. However, to mimic the mean temperature, amount, and frequency of available groundwater etc. expected in the near-surface repository would require a great amount of testing time to be able to detect any release. Therefore, an accelerated chemical durability test, the PCT, is employed to gauge the chemical durability of glass waste forms. The PCT was conducted on the DuraLith and Ceramicrete SBW and HSW test specimens to obtain some initial data using the test. Further testing will be necessary to determine the relevancy of the PCT to these non-glass waste forms and to interpret the results with respect to waste-form performance

The PCT was conducted in accordance with the ASTM procedure C1285-02 "Standard Test Methods for Determining Chemical Durability of Nuclear, Hazardous, and Mixed Waste Glasses: The Product Consistency Test (PCT)" (ASTM 2002). The waste form was ground and then sieved through 75 and $150 \mu \mathrm{m}(-100$ to $+200 \mathrm{mesh})$ stainless steel sieves. The waste-form particles were cleaned by rinsing and washing with DI water and then ethanol in an ultrasonic cleaner. However, there was not a significant reduction in cloudiness of the wash solution with successive washes. So another washing procedure was tested and used. A larger particle size of 0.84 to $2.00 \mathrm{~mm}(-10$ to +20 mesh) was tested along with an acetone rinse and wash for both particle sizes. Even with an acetone rinse of the smaller particle size, the solution could not be decanted easily because of the particulates present. With the larger particle size and the acetone rinse, the wash solutions were still slightly cloudy, but better than with the DI water and ethanol. It was decided to proceed with both particle sizes: a 7-day test with 75- to $150-\mu \mathrm{m}$ size particles to follow PCT procedure and a 1-day test with the 0.84 - to $2.00-\mathrm{mm}$ size particles to evaluate a slower release mechanism for these low-temperature waste forms. The low activity reference material (LRM) glass (Ebert and Wolf 1999) was used as a standard reference material in each test and had the same particle size correlating to the 7-day and 1-day PCT. All PCT samples were cleaned twice in acetone for 30 seconds in an ultrasonic bath and dried at $90^{\circ} \mathrm{C}$ for 1 hour. See Attachment $\mathrm{C}$ for more details on testing for the PCT modifications.

Approximately $1.5 \mathrm{~g}$ of waste form was weighed and placed into a 22-mL desensitized Type 304L stainless steel container (see Figure 3.1). The volume of de-ionized water for each sample was measured by mass and added to the requisite stainless steel container. The waste form was precisely weighed and the leachate volume precisely controlled to achieve a solution volume-to-waste form ratio of $10 \mathrm{~mL} / \mathrm{g}$ waste form. The container and its contents were held without agitation at $90^{\circ} \mathrm{C}$ for 1 day $(-10$ to +20 mesh particle size) and 7 days (-100 to +200 mesh particle size $)$. The normalized release was then calculated according to the following equation: 


$$
\mathrm{NL}_{\mathrm{i}}=\frac{\mathrm{c}_{\mathrm{i}}(\text { sample })}{\left(\mathrm{f}_{\mathrm{i}}\right)(\mathrm{SA} / \mathrm{V})}
$$

where

$$
\begin{aligned}
\mathrm{NL}_{\mathrm{i}} & =\text { normalized release, } \mathrm{g}_{\text {waste form }} / \mathrm{m}^{2} \\
\mathrm{c}_{\mathrm{i}}(\text { sample) } & =\text { concentration of element "i } \mathrm{i} \text { " in the solution, } \mathrm{g}_{\mathrm{i}} / \mathrm{L} \\
\mathrm{f}_{\mathrm{i}} & =\text { fraction of element "i } \mathrm{i} \text { " in the unleached waste form (unitless) } \\
\mathrm{SA} / \mathrm{V} & =\text { surface area of the final waste form divided by the leachate volume, } \mathrm{m}^{2} / \mathrm{L} .
\end{aligned}
$$

See Attachment $\mathrm{C}$ for details of PCT testing-time modifications for the larger particle size samples. The initial and final $\mathrm{pH}$ values of the solution were taken. Aliquots of the solution were filtered through a $0.45-\mu \mathrm{m}$ filter and analyzed with ICP.

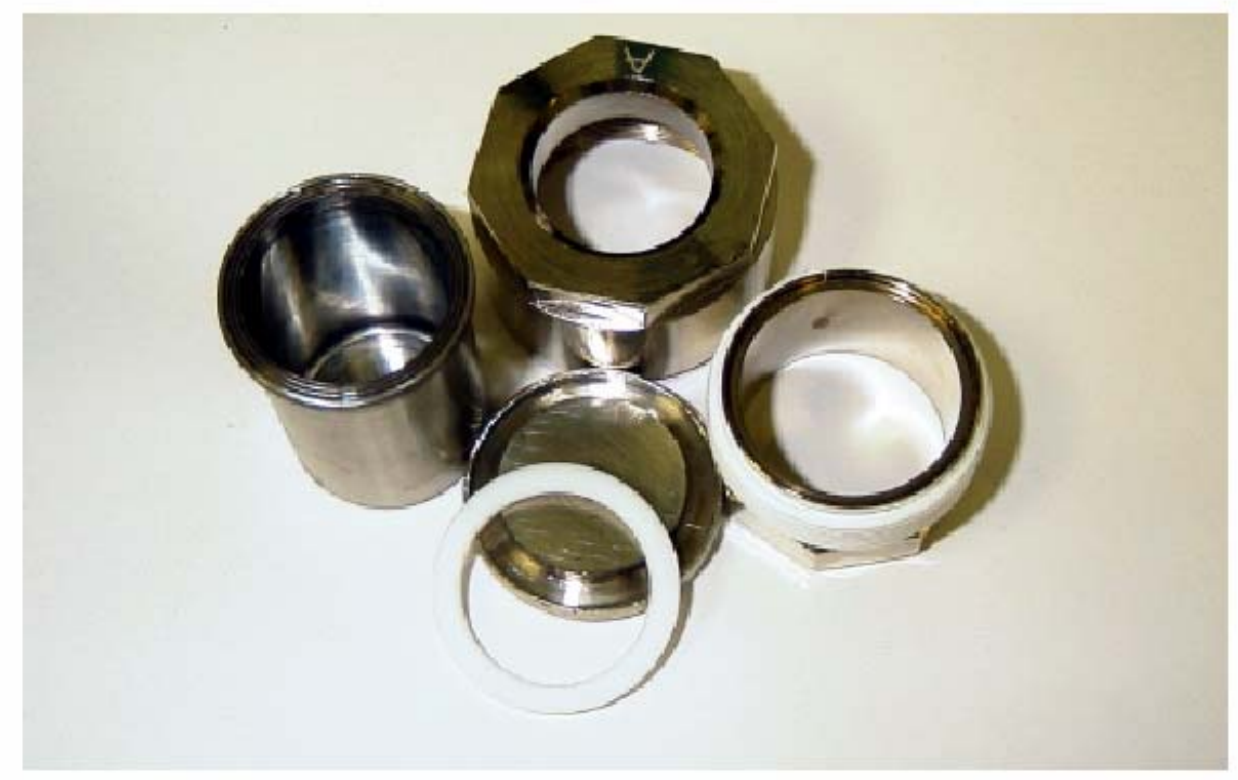

Figure 3.1. Components of PCT Vessel

(Pictured are the Desensitized Type 304L stainless steel, $22 \mathrm{~mL}$, PCT vessel and lid, a white Teflon gasket that seals the vessel and lid when the assembly is closed and tightened, and the nickel-plated brass, nut, and screw vessel tightening assembly.)

\subsection{Durability by ANSIIANS 16.1 Leachability Index Test}

The ANSI/ANS 16.1 (ANSI/ANS 1986) protocol tests diffusivity and surface release of constituents in a monolithic waste form. The ANSI/ANS 16.1 test provides a "Leachability Index." This test is typically used for characterizing low-level waste forms such as bitumen, grouts, and other cementitious materials. The LI is calculated from a series of 10 immersions in water at two, five, seventeen, and four 24-hour intervals followed by 14-, 28-, and 43-day intervals for a 90-day total leach time.

For each sample tested with the ANSI/ANS 16.1 test, two high-density polyethylene 4-L containers were used with a wax paper seal pressed into a metal crew cap cover. The samples were suspended from 
the lids by monofilament nylon lines supporting the samples from each end of the cylinder (Figure 3.2). Each container was filled with a calculated volume $(\sim 2 \mathrm{~L})$ of de-ionized (DI) water. The volume of DI water needed was obtained by measuring the diameter and length of the monolith in several locations and calculating the surface area of the cylinder from the average of the measurements. The leachant volume is 10 times the surface area of the sample. Following the ANSI/ANS 16.1 test schedule, samples were removed from one container, letting the free water drip back into the test solution and then moving the monolith sample into fresh DI water in the second container.

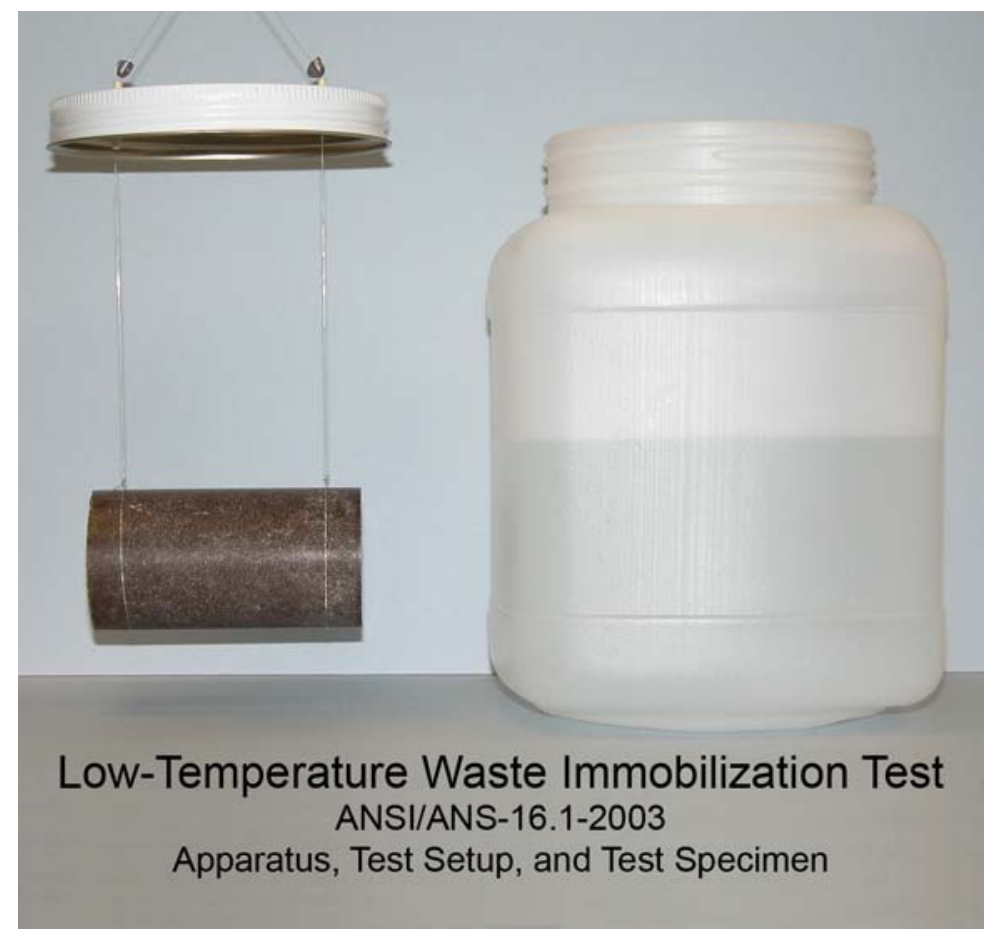

Figure 3.2. Configuration for ANS 16.1 Detachability Index Test

(Pictured are the sample suspended from the lid along with the vessel that it was placed in for ANSI/ANS 16.1 testing.)

Eight samples were tested following the ANSI/ANS 16.1 procedure. Two samples each of the DuraLith and Ceramicrete with the HSW and SBW waste simulants were selected for testing. Sample identification was used to select samples that were not sequentially identical to avoid samples cast at the same time and to determine if differences in durability could be observed by selecting two samples having distinct differences, such as color and inhomogeneities, for the Ceramicrete HSW and SBW and DuraLith SBW samples. For the DuraLith HSW samples, the distinct difference used was the color. One sample each of the light and dark gray was selected for testing.

At the end of each leach interval, two 20 -mL aliquots were taken from the test solution. Solution temperature and $\mathrm{pH}$ were measured, and visual observations of the waste form and solution were recorded before the solution was discarded. The aliquots were sent for chemical analysis by inductively coupled plasma-atomic emission spectroscopy (ICP-AES), inductively coupled plasma-mass spectroscopy (ICPMS), and ion chromatography (IC). Upon completion of the final immersion, the samples were 
suspended in an empty 4-L container with the lid sealed to keep the samples moist and in the final condition at the end of the test.

The LI was then calculated according to the following equation:

$$
L_{n}=-\log \left(\frac{D_{n}}{c m^{2} s^{-1}}\right)
$$

where $L_{n}$ is the LI, and $D_{n}$ is the effective diffusivity. The effective diffusivity is defined as:

$$
\mathrm{D}=\pi\left[\frac{\left(\mathrm{a}_{\mathrm{n}} / \mathrm{A}_{\mathrm{o}}\right)}{(\Delta \mathrm{t})_{\mathrm{n}}}\right]^{2}\left(\frac{\mathrm{V}}{\mathrm{S}}\right)^{2} \mathrm{~T}
$$

where $\quad \mathrm{D}=$ effective diffusivity $\left(\mathrm{cm}^{2} / \mathrm{s}\right)$

$\mathrm{V}=$ volume of specimen $\left(\mathrm{cm}^{2}\right)$

$\mathrm{S}=$ geometric surface area of the specimen as calculated from measured dimensions $\left(\mathrm{cm}^{2}\right)$

$\mathrm{T}=$ leaching time representing the "mean time" of the leaching interval (s)

$\mathrm{a}_{\mathrm{n}}=$ quantity of a given element released from the specimen during the leaching interval $\mathrm{n}$

$\mathrm{A}_{\mathrm{o}}=$ total quantity of a given element in the specimen at the beginning of the first leaching interval

$\Delta \mathrm{t}_{\mathrm{n}}=$ duration of the $\mathrm{n}$ 'th leaching interval (s)

\subsection{Compressive Strength Testing}

Compressive strengths of the DuraLith and Ceramicrete waste forms were tested on as-received specimens and on specimens irradiated to $1.0 \mathrm{E} 8 \mathrm{rad}$. The gamma irradiation of the 12 samples (three of each waste-simulant/waste-form combination were conducted in the ${ }^{60} \mathrm{Co}$ Gamma Irradiation Facility at the Hanford Site. The facility contains 37 stainless steel irradiation tubes positioned in a stainless steel water-filled tank. Two arrays of ${ }^{60} \mathrm{Co}$ with a combined inventory of $2.07 \mathrm{E} 14 \mathrm{~Bq}(5600 \mathrm{Ci})$ are located near the bottom of the tank. The irradiation tubes, which are sealed on the bottom, allow the samples to be irradiated in a dry environment. Dose rates in the tubes were previously calibrated and are traceable to the National Institute of Standards and Technology (NIST). To complete the irradiations in a timely manner, two different dose rates were used as shown in Table 3.1.

The samples were lowered into an irradiation tube to a position that provided the desired dose rate. The samples were left in the tube for a specific amount of time to attain the required total delivered dose as shown in Table 3.1. After the irradiations were completed, both as-received and irradiated specimens were tested for compressive strength according to the ASTM C-39/C-39M-05 (ASTM 2005) procedure. 
Table 3.1. Sample Irradiation Dose Rate and Exposure Time

\begin{tabular}{||l|c|l|c|c|c||}
\hline \multicolumn{1}{|c|}{ Sample ID \# } & $\begin{array}{c}\text { Sample } \\
\text { Material }\end{array}$ & $\begin{array}{c}\text { Waste } \\
\text { Type }\end{array}$ & $\begin{array}{c}\text { Total } \\
\text { Dose Rate } \\
\text { (R/hr) }\end{array}$ & $\begin{array}{c}\text { Total } \\
\text { Exposure } \\
\text { Time (hr) }\end{array}$ & $\begin{array}{c}\text { Delivered } \\
\text { Dose (R) }\end{array}$ \\
\hline HSN/NS 102105/12 & Ceramicrete & HSW & $3.6 \mathrm{E}+5$ & 277.8 & $1.0 \mathrm{E}+8$ \\
\hline SBN/NS 100805/2 & Ceramicrete & SBW & $3.6 \mathrm{E}+5$ & 277.8 & $1.0 \mathrm{E}+8$ \\
\hline HW TB-9R3-C-S-4 & DuraLith & HSW & $3.6 \mathrm{E}+5$ & 277.8 & $1.0 \mathrm{E}+8$ \\
\hline ISW ED-SA3-D-1 & DuraLith & SBW & $3.6 \mathrm{E}+5$ & 277.8 & $1.0 \mathrm{E}+8$ \\
\hline SBN/NS 101605/19 & Ceramicrete & SBW & $8.3 \mathrm{E}+4$ & 1204.8 & $1.0 \mathrm{E}+8$ \\
\hline SBN/NS 101605/20 & Ceramicrete & SBW & $8.3 \mathrm{E}+4$ & 1204.8 & $1.0 \mathrm{E}+8$ \\
\hline HSN/NS 101705/2 & Ceramicrete & HSW & $8.3 \mathrm{E}+4$ & 1204.8 & $1.0 \mathrm{E}+8$ \\
\hline HSN/NS 102105/11 & Ceramicrete & HSW & $8.3 \mathrm{E}+4$ & 1204.8 & $1.0 \mathrm{E}+8$ \\
\hline ISW ED-SA3-E-6 & DuraLith & SBW & $8.3 \mathrm{E}+4$ & 1204.8 & $1.0 \mathrm{E}+8$ \\
\hline ISW ED-SA3-B-3 & DuraLith & SBW & $8.3 \mathrm{E}+4$ & 1204.8 & $1.0 \mathrm{E}+8$ \\
\hline HW TB-9R3-D-S-4 & DuraLith & HSW & $8.3 \mathrm{E}+4$ & 1204.8 & $1.0 \mathrm{E}+8$ \\
\hline HW TB-9R3-C-S-5 & DuraLith & HSW & $8.3 \mathrm{E}+4$ & 1204.8 & $1.0 \mathrm{E}+8$ \\
\hline
\end{tabular}

This compressive strength procedure is used to determine the compressive strength of cylindrical samples. Care must be used in the interpretation of the significance of compressive strength determinations with this test method because compressive strength is not an intrinsic property of these materials. Compressive-strength values depend on the size and shape of the sample, batching, mixing procedures, the methods of sampling, molding, and fabrication as well as the age, temperature, and moisture conditions during curing.

The sample is loaded into the testing apparatus so that the axis of the specimen is aligned with the center of thrust of the spherically seated block of the testing apparatus. As the spherically seated block is brought to bear on the specimen, it can be rotated so that uniform seating is obtained. Then the load is applied at a rate of movement (platen to crosshead measurement) corresponding to a stress rate on the sample of $0.25 \pm 0.05 \mathrm{MPa} / \mathrm{s}(35 \pm 7 \mathrm{psi} / \mathrm{s})$ continuously and without shock until the load indicator shows that the load is decreasing steadily and the sample displays a well-defined fracture pattern. A servohydraulic test machine was used to apply load to the cylindrical specimens, which were supported between parallel platens, in this test as shown in Figure 3.3. A constant displacement rate of $1.3 \mathrm{~mm} / \mathrm{min}$ $(0.050 \mathrm{in} / \mathrm{min})$ was used for all of the tests. Load and displacement were measured during the test for each specimen. The compressive strength is then calculated by dividing the maximum load carried by the sample during the test by the average cross-sectional area determined for the sample before the test expressed to the nearest $10 \mathrm{psi}(0.07 \mathrm{MPa})$. 


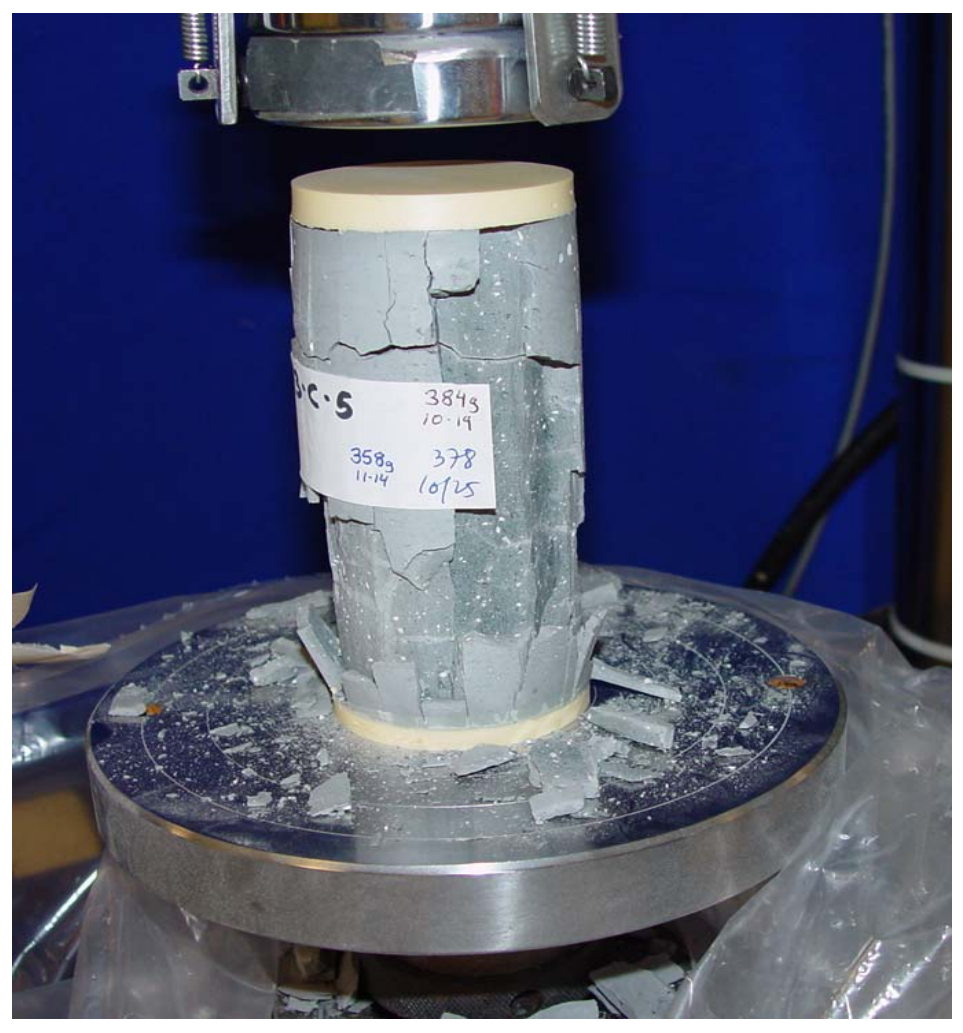

Figure 3.3. Specimen in Compression Platens, Showing Typical Failure

(The ends of the specimen were capped, and the upper platen swivels to provide uniform loading.) 


\subsection{Results of PNNL Testing}

This section presents the results of durability (modified PCT and ANSI/ANS 16.1) and compressive strength testing (both irradiated and as received samples) of low-temperature waste forms performed at PNNL on the test specimens supplied by the participating contractors.

\subsection{PCT Results}

Table 4.1 and Table 4.2 show the results of the 7-day PCT tests performed according to the standard PCT procedure. The Ceramicrete samples had a final $\mathrm{pH}$ similar to the standard glass tested at the same time whereas the DuraLith samples had a slightly higher final $\mathrm{pH}$. All of the samples had fairly high $\mathrm{Na}$ and $\mathrm{K}$ normalized releases. The Ceramicrete samples also had high $\mathrm{P}$ normalized releases compared to the standard LRM glass. The HSW and SBW wastes had phosphorus releases of $\sim 16 \mathrm{~g} / \mathrm{m}^{2}$ and $\sim 7 \mathrm{~g} / \mathrm{m}^{2}$, respectively, compared to the standard LRM glass phosphorus release of $0.086 \mathrm{~g} / \mathrm{m}^{2}$. Care must be taken in applying these results because the PCT protocol was originally designed for borosilicate glass and may not apply directly to alternate waste forms.

Table 4.1. $\mathrm{pH}$ Results of the PCT 7-Day $-100,+200$ mesh Particle Size Samples

\begin{tabular}{|l|c|c|c|c||}
\hline Sample ID & $\begin{array}{c}\text { Sample } \\
\text { Material }\end{array}$ & $\begin{array}{c}\text { Waste } \\
\text { Type }\end{array}$ & $\begin{array}{c}\text { Initial } \\
\text { pH }\end{array}$ & $\begin{array}{c}\text { Final } \\
\text { pH }\end{array}$ \\
\hline HSN/NS 702105/9 & Ceramicrete & HSW & 5.57 & 10.95 \\
\hline HSN/NS 102205/14 & Ceramicrete & HSW & 5.57 & 10.90 \\
\hline SBN/NS 101305/6 & Ceramicrete & SBW & 5.57 & 9.66 \\
\hline SBN/NS 101505/14 & Ceramicrete & SBW & 5.57 & 9.65 \\
\hline VSL/HSW TB-9R3-B-S-4 & DuraLith & HSW & 5.57 & 12.11 \\
\hline VSL/HSW TB-9R3-C-S-6 & DuraLith & HSW & 5.57 & 12.21 \\
\hline VSL/SBW ED-SA3-B-1 & DuraLith & SBW & 5.57 & 11.93 \\
\hline VSL/SBW ED-SA3-C-2 & DuraLith & SBW & 5.57 & 11.99 \\
\hline LRM & Std Glass & LAW & 5.57 & 10.87 \\
\hline Blank & & & 5.57 & 7.80 \\
\hline \hline
\end{tabular}

Table 4.2. PCT Results of the 7 Day $-100,+200$ Mesh Particle Size Samples

\begin{tabular}{||l|c|c|c|c|c|c|c|c||}
\hline \hline Sample ID & $\begin{array}{c}\text { Sample } \\
\text { Material }\end{array}$ & $\begin{array}{c}\text { Waste } \\
\text { Type }\end{array}$ & $\begin{array}{c}\mathbf{N a} \\
\mathbf{g} / \mathbf{m}^{2}\end{array}$ & $\begin{array}{c}\mathbf{K} \\
\mathbf{g} / \mathbf{m}^{2}\end{array}$ & $\begin{array}{c}\mathbf{S i} \\
\mathbf{g} / \mathbf{m}^{2}\end{array}$ & $\begin{array}{c}\mathbf{M g} \\
\mathbf{g} / \mathbf{m}^{2}\end{array}$ & $\begin{array}{c}\mathbf{A l} \\
\mathbf{g} / \mathbf{m}^{2}\end{array}$ & $\begin{array}{c}\mathbf{P} \\
\mathbf{g} / \mathbf{m}^{2}\end{array}$ \\
\hline HSN/NS 702105/9 & Ceramicrete & HSW & 14.76 & 44.06 & 0.249 & 0.003 & -- & 16.84 \\
\hline HSN/NS 102205/14 & Ceramicrete & HSW & 14.76 & 42.62 & 0.257 & 0.002 & -- & 16.51 \\
\hline SBN/NS 101305/6 & Ceramicrete & SBW & 26.56 & 44.40 & 0.335 & 0.008 & -- & 7.08 \\
\hline SBN/NS 101505/14 & Ceramicrete & SBW & 28.08 & 45.11 & 0.048 & 0.008 & -- & 7.32 \\
\hline VSL/HSW TB-9R3-B-S-4 & DuraLith & HSW & 17.74 & 8.91 & 0.656 & $<0.005$ & 0.025 & -- \\
\hline VSL/HSW TB-9R3-C-S-6 & DuraLith & HSW & 17.53 & 8.69 & 0.450 & $<0.049$ & 0.087 & -- \\
\hline VSL/SBW ED-SA3-B-1 & DuraLith & SBW & 20.43 & 18.23 & 0.117 & $<0.001$ & 0.061 & -- \\
\hline VSL/SBW ED-SA3-C-2 & DuraLith & SBW & 20.33 & 23.86 & 0.137 & $3.13 \mathrm{E}-06$ & 0.079 & -- \\
\hline LRM & Std Glass & LAW & 0.452 & 0.147 & 0.080 & 0.100 & 0.071 & 0.086 \\
\hline
\end{tabular}


Table 4.3 and Table 4.4 show the results of the 1-day modified PCT procedure tests. The final $\mathrm{pH}$ values of the leachates followed the same trend as for the 7-day test results. Because of the order of magnitude smaller total surface area for the larger mesh size being tested $\left(0.207 \mathrm{~m}^{2} / \mathrm{L}\right.$ for the $-10,+20$ mesh and $2.637 \mathrm{~m}^{2} / \mathrm{L}$ for the $100,+200$ mesh Ceramicrete samples and $0.233 \mathrm{~m}^{2} / \mathrm{L}$ for the $-10,+20$ mesh and $2.972 \mathrm{~m}^{2} / \mathrm{L}$ for the $100,+200$ mesh DuraLith samples), the normalized releases of $\mathrm{Na}, \mathrm{K}$, and $\mathrm{P}$ in these tests were about an order of magnitude higher than the standard 7-day tests.

Table 4.3. PCT Results of 1-Day $-10,+20$ mesh Particle Size Samples

\begin{tabular}{||l|c|c|c|c||}
\hline Sample ID & $\begin{array}{c}\text { Sample } \\
\text { Material }\end{array}$ & $\begin{array}{c}\text { Waste } \\
\text { Type }\end{array}$ & Initial pH & Final pH \\
\hline HSN/NS 702105/9 & Ceramicrete & HSW & 5.57 & 10.02 \\
\hline HSN/NS 102205/14 & Ceramicrete & HSW & 5.57 & 10.25 \\
\hline SBN/NS 101305/6 & Ceramicrete & SBW & 5.57 & 8.70 \\
\hline SBN/NS 101505/14 & Ceramicrete & SBW & 5.57 & 8.61 \\
\hline VSL/HSW TB-9R3-B-S-4 & DuraLith & HSW & 5.57 & 12.09 \\
\hline VSL/HSW TB-9R3-C-S-6 & DuraLith & HSW & 5.57 & 12.26 \\
\hline VSL/SBW ED-SA3-B-1 & DuraLith & SBW & 5.57 & 12.10 \\
\hline VSL/SBW ED-SA3-C-2 & DuraLith & SBW & 5.57 & 12.21 \\
\hline LRM & Std Glass & LAW & 5.57 & 9.60 \\
\hline Blank & & & 5.57 & 7.94 \\
\hline
\end{tabular}

Table 4.4. PCT Results of the 1-Day $-10,+20$ mesh Particle Size Samples

\begin{tabular}{||l|c|c|c|c|c|c|c|c||}
\hline \hline Sample ID & $\begin{array}{c}\text { Sample } \\
\text { Material }\end{array}$ & $\begin{array}{c}\text { Waste } \\
\mathbf{T y p e}\end{array}$ & $\begin{array}{c}\mathbf{N a} \\
\mathbf{g} / \mathbf{m}^{2}\end{array}$ & $\begin{array}{c}\mathbf{K} \\
\mathbf{g} / \mathbf{m}^{2}\end{array}$ & $\begin{array}{c}\mathbf{S i} \\
\mathbf{g} / \mathbf{m}^{2}\end{array}$ & $\begin{array}{c}\mathbf{M g} \\
\mathbf{g} / \mathbf{m}^{2}\end{array}$ & $\begin{array}{c}\mathbf{A l} \\
\mathbf{g} / \mathbf{m}^{2}\end{array}$ & $\begin{array}{c}\mathbf{P} \\
\mathbf{g} / \mathbf{m}^{2}\end{array}$ \\
\hline HSN/NS 702105/9 & Ceramicrete & HSW & 250 & 403 & 8.81 & 0.228 & -- & 202 \\
\hline HSN/NS 102205/14 & Ceramicrete & HSW & 284 & 427 & 6.64 & 0.119 & -- & 203 \\
\hline SBN/NS 101305/6 & Ceramicrete & SBW & 358 & 547 & 1.20 & 0.538 & -- & 92.5 \\
\hline SBN/NS 101505/14 & Ceramicrete & SBW & 360 & 539 & 1.28 & 0.474 & -- & 94.0 \\
\hline VSL/HSW TB-9R3-B-S-4 & DuraLith & HSW & 211 & 107 & 6.48 & $<0.061$ & 0.138 & -- \\
\hline VSL/HSW TB-9R3-C-S-6 & DuraLith & HSW & 218 & 106 & 3.59 & $<0.010$ & 0.587 & -- \\
\hline VSL/SBW ED-SA3-B-1 & DuraLith & SBW & 228 & 194 & 1.49 & $<0.001$ & 0.994 & -- \\
\hline VSL/SBW ED-SA3-C-2 & DuraLith & SBW & 203 & 183 & 1.67 & $<0.011$ & 1.52 & -- \\
\hline LRM & Std Glass & LAW & 0.515 & 0.243 & 0.212 & 0.088 & 0.263 & 0.164 \\
\hline
\end{tabular}

\subsection{ANSIIANS 16.1 Durability Results}

The ANSI/ANS 16.1 was conducted on four DuraLith and four Ceramicrete specimens for the entire 90-day test period. Some interesting phenomena were noted early in the tests, such as cracks in samples, pieces spalling from a specimen, solution discoloration, and formation of bubbles on the sample surface. Because of these observed changes, some additional measurements were taken during the test. An additional specimen of the DuraLith waste form with the HSW simulant was tested after one of the first two specimens broke during the 5-hour leach interval during the first day of testing. And because some samples began to discolor the DI water, the $\mathrm{pH}$ of the solution was measured to determine if that may be associated with the water discoloration (see Table 4.5). Table 4.5 summarizes the observations from each of the tests. 
Table 4.5. $\mathrm{pH}$ of ANSI/ANS 16.1 Tests Leach Solutions Throughout the 90 Days of Testing

\begin{tabular}{|l|c|c|c|c|c|c|c|c|c|c||}
\hline Sample ID & $\begin{array}{c}\text { Sample } \\
\text { Material }\end{array}$ & $\begin{array}{c}\text { Waste } \\
\text { Type }\end{array}$ & $\begin{array}{c}\mathbf{7} \text { Hour } \\
\mathbf{p H}\end{array}$ & $\begin{array}{c}\mathbf{4 8} \mathbf{~ H o u r} \\
\mathbf{p H}\end{array}$ & $\begin{array}{c}\mathbf{7 2} \mathbf{H o u r} \\
\mathbf{p H}\end{array}$ & $\begin{array}{c}\mathbf{9 6} \mathbf{H o u r} \\
\mathbf{p H}\end{array}$ & $\begin{array}{c}\mathbf{1 2 0} \mathbf{H o u r} \\
\mathbf{p H}\end{array}$ & $\begin{array}{c}\mathbf{1 4} \text { Day } \\
\mathbf{p H}\end{array}$ & $\begin{array}{c}\mathbf{2 8} \mathbf{D a y} \\
\mathbf{p H}\end{array}$ & $\begin{array}{c}\mathbf{4 3} \text { Day } \\
\mathbf{p H}\end{array}$ \\
\hline $\begin{array}{l}\text { HSN/NS } \\
102005 / 6\end{array}$ & Ceramicrete & HSW & 9.44 & -- & -- & 8.0 & $6.5-7.0$ & $8.0-8.5$ & 9.0 & $\sim 9.5$ \\
\hline $\begin{array}{l}\text { HSN/NS } \\
102405 / 21\end{array}$ & Ceramicrete & HSW & 9.50 & -- & -- & $7.0-7.5$ & $6.5-7.0$ & $8.0-8.5$ & 9.0 & $\sim 10$ \\
\hline $\begin{array}{l}\text { SBN/NS } \\
101405 / 15\end{array}$ & Ceramicrete & SBW & 9.10 & -- & -- & $6.5-7.0$ & $6.0-6.5$ & $7.0-7.5$ & 7.1 & $\sim 7.4$ \\
\hline $\begin{array}{l}\text { SBN/NS } \\
101505 / 16\end{array}$ & Ceramicrete & SBW & 9.08 & -- & -- & $6.5-7.0$ & $6.0-6.5$ & $7.0-7.5$ & 7.4 & $\sim 7.4$ \\
\hline $\begin{array}{l}\text { VSL/HSW } \\
\text { TB-9R3-B-S-3 }\end{array}$ & DuraLith & HSW & 11.38 & $10.0-10.5$ & $10.0-10.5$ & $9.5-10.0$ & $9.5-10.0$ & $11.0-12.0$ & 12 & $\sim 11.8$ \\
\hline $\begin{array}{l}\text { VSL/HSW } \\
\text { TB-9R3-E-S-5 }\end{array}$ & DuraLith & HSW & 10.80 & 9.5 & $9.5-10.0$ & $8.5-9.0$ & $8.0-9.0$ & 11.0 & 11.5 & 11.5 \\
\hline $\begin{array}{l}\text { VSL/SBW } \\
\text { ED-SA3-D-6 }\end{array}$ & DuraLith & SBW & $\sim 8.5$ & $9.0-9.5$ & $9.0-9.5$ & $8.0-8.5$ & $8.0-8.5$ & 11.5 & 11.5 & $\sim 11.5$ \\
\hline $\begin{array}{l}\text { VSL/SBW } \\
\text { ED-SA3-C-1 }\end{array}$ & DuraLith & SBW & $\sim 8.5$ & $8.5-9.0$ & $8.5-9.0$ & $8.5-9.0$ & $9.0-9.5$ & 11.5 & 11.5 & $\sim 11.5$ \\
\hline
\end{tabular}

The leachates from the Ceramicrete HSW samples had $\mathrm{pH}$ values $<10$ throughout the test period. No other observations were made until the end of the 28-day test interval when the surface of both samples was noted to be rough with areas of surface swelling $<1 \mathrm{~mm}$ in diameter appearing over the entire surface. At the end of the test, the test specimen had surface cracking over the entire specimen. The cracks were bordered by a white film, which enhanced the size of the crack. These cracks opened further, and the sample swelled once the test was complete and the samples dried (Figure 4.1, top two photos).

For the two Ceramicrete SBW samples, the $\mathrm{pH}$ measured about 7 from the fourth day until the end of the test. The 5-hour test interval solution had a $\mathrm{pH}$ of about 9. At the end of the 14-day test interval, a whitish film had developed, mainly on the lower bottom of both samples. At the end of the 28- and 43-day test intervals, this thickened and became more distinguished. The photos in Figure 4.1 of the SBN/NS samples show the white layer. In the photo, it appears as a white solid, but when the samples were in solution, the layer appeared as a spongy gel. CH2MHill has observed this material in its ANS 16.1 testing and has identified the material as $\mathrm{Na}_{2} \mathrm{HPO}_{4}$. The formation can be controlled by adjusting the waste $\mathrm{pH}$ to 4 or less rather than 5 as was done in the current sample-preparation process. Further, $\mathrm{MgO}$ rather than $\mathrm{NaOH}$ may be required to adjust the $\mathrm{pH}$. If the $\mathrm{MgO}$ concentration is too low and the $\mathrm{pH}$ is not adequately controlled, then the $\mathrm{Na}_{2} \mathrm{HPO}_{4}$ forms rather than the preferred $\mathrm{NaH}_{2} \mathrm{PO}_{4}$.

The DuraLith HSW samples had a difference in appearance from the beginning with one being light gray and the other dark gray. Both performed similarly except the dark gray sample cracked, and pieces began falling off during the 5-hour test interval; one end of the sample came completely off losing 3 to $4 \mathrm{~mm}$ of the sample. At the end of the 96-hour, 120-hour, 14-day, 28-day, and 43-day test intervals, fragments of the sample were also found at the bottom of the test vessel. While the sample was being moved to the next test vessel following the 96-hour test interval, there was not enough sample left for the support line to hold onto the sample, and the line slipped off. The support line was readjusted and placed further back on the sample. At the completion of the test, the sample fell apart (Figure 4.1, broken sample) as it was being moved to the storage container. 


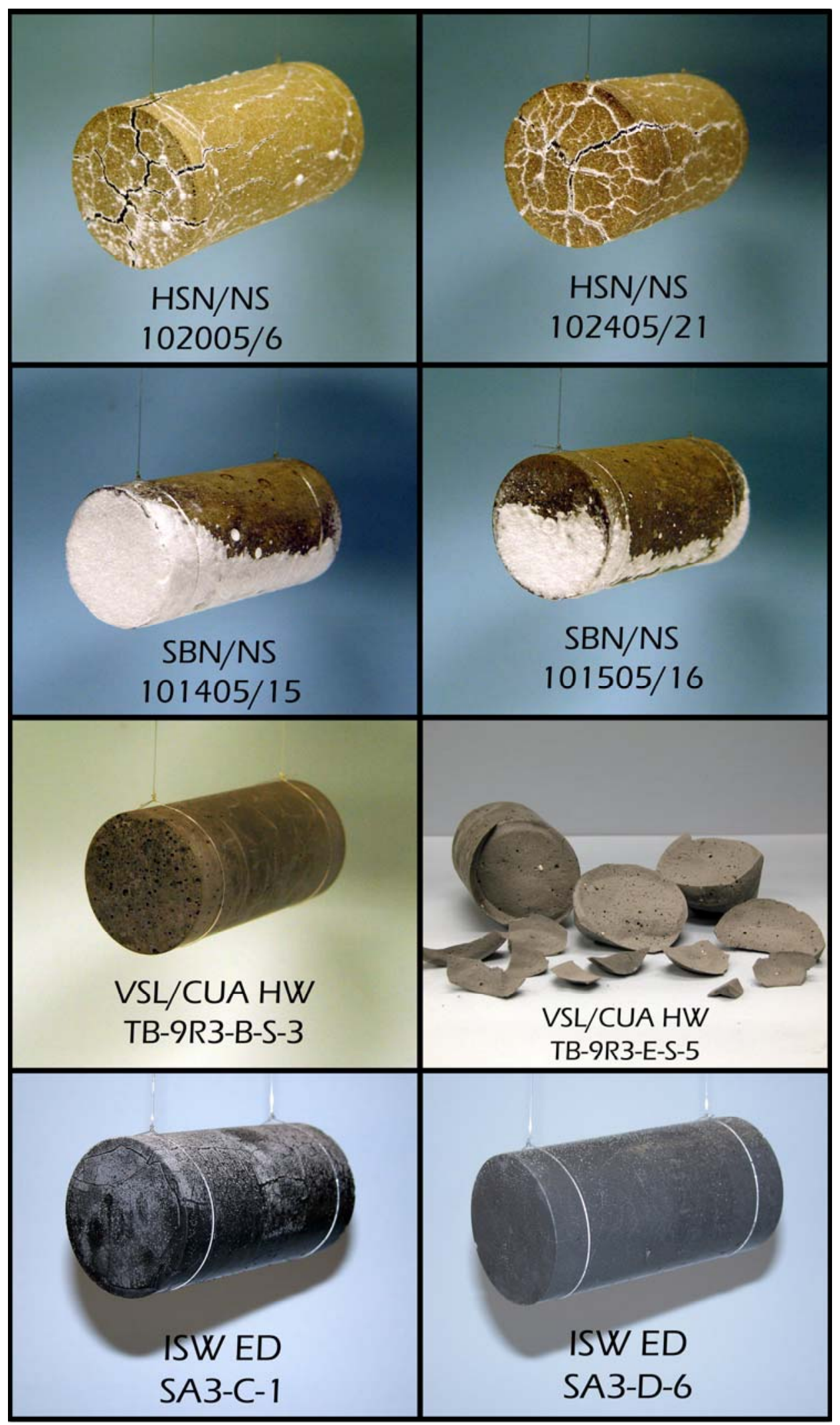

Figure 4.1. Final Waste Forms After 90 Days of ANSI/ANS 16.1 Testing 
Both samples were similar in $\mathrm{pH}$ and discoloration of the leach solution. At the completion of the 5-hour test interval, it was observed in both tests that the solution appeared slightly discolored. It was decided to measure the $\mathrm{pH}$ of all of the tests at this point to determine if that may be a factor in the water discoloration. The $\mathrm{pH}$ of the light gray sample (TB-9R3-B-S-3) was 10.8 while for the dark gray sample (TB-9R3-E-S-5), the $\mathrm{pH}$ was 11.38. Water discoloration was observed at the end of all of the test intervals except for the final 43-day test interval for the dark gray sample. The $\mathrm{pH}$ values for TB-9R3-E-S-5 were measured at about 10 for the 5-day test interval but increased to about 12 for the 14-, 28-, and 43-day test intervals. For sample TB-9R3-B-S-3, the pH was lower, at about 9.5, at the beginning of the 5-day test interval, but decreased below 9 by the fifth day. After the 14-, 28-, and 43-day test intervals, the $\mathrm{pH}$ was between 11 and 11.5. As seen in the photo in Figure 4.1, monolith TB-9R3-BS-3 (light gray) appears in good physical shape at the end of the testing.

Because TB-9R3-E-S-5 (dark gray sample) was experiencing problems with cracking and loss of sample, it was decided to do an additional test with another dark gray sample, TB-9R3-D-S-6. At the end of the 2-hour test interval, it was discovered that the sample had shattered into many pieces (see Figure 4.2). As the test operator was working in the laboratory, he had heard a dull thump, but did not know where the sound came from; he related it to the breaking of the sample. The test was discontinued. The $\mathrm{pH}$ was measured at approximately 10 .

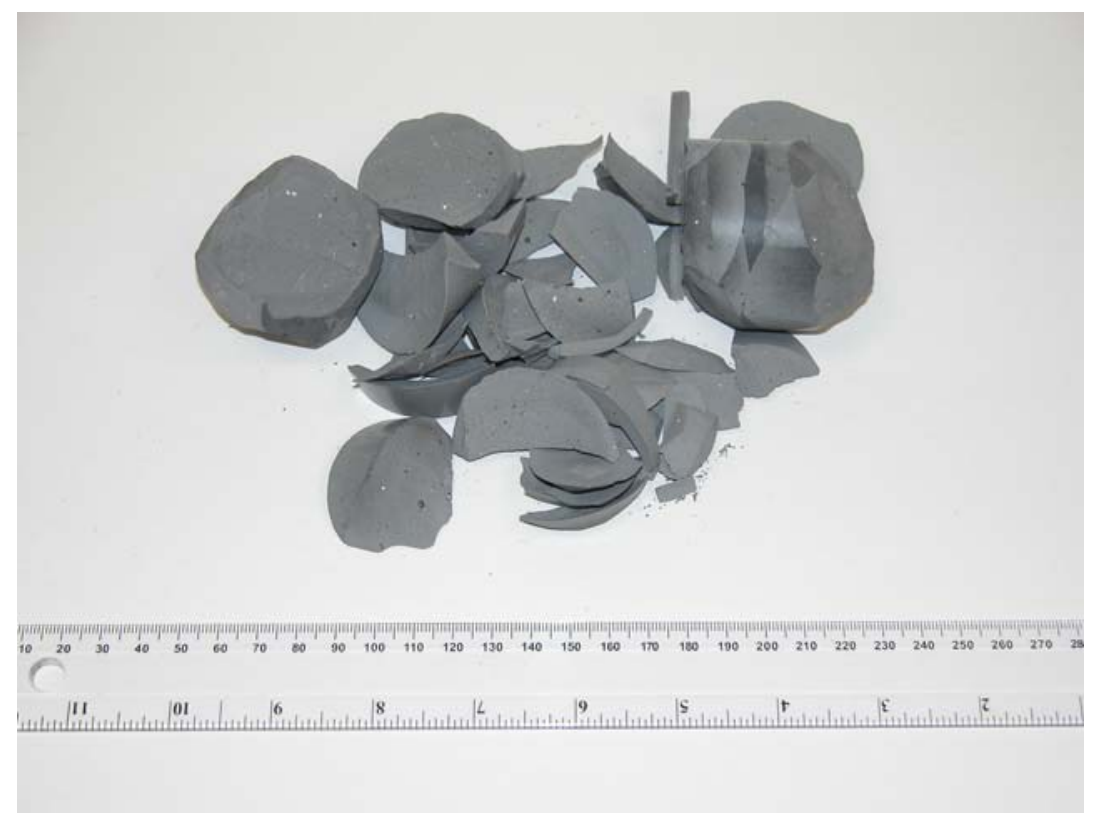

Figure 4.2. Sample TB-9R3-D-S-6 After 2 Hours of ANSI/ANS 16.1 Testing

Another test was immediately started with a dark gray sample (TB-9R3-C-S-2). Thirty minutes after the test started, the test operator, sitting near the test set-up, heard a dull thump again. He immediately opened the vessel and observed that the sample had split in half. Over the next 10 minutes, the sample continued popping, and pieces were observed energetically falling off the sample. Observed in both samples that split were streams of bubbles coming from distinct areas of the sample, like carbonation observed rising from a single location in a soda drink. Cracks were also observed on the surface of this sample. This test was also discontinued. VSL speculated that the cracking may be related to the 
formation of undesirable calcium silicates in certain composition regions. By adjusting the quantity of one of the batching materials, VSL has since obtained samples that do not crack in water.

The DuraLith SBW samples had a pH level about 9 for the short test period (5-day leach test) and 11.5 for the 14-, 28-, and 43-day tests. A slight discoloration of the water was observed throughout the testing periods. At the end of the 48-hour test, the samples were completely covered in $\sim 1$-mm bubbles; this was the only test period this phenomenon was observed. Also, at this time, small cracks were observed on the sample surface. These cracks were observed throughout the remainder of the tests and grew more distinct as the test progressed (see Figure 4.1, bottom photos). At the end of some of the tests, the bottom of the vessel had dark stains in a spot or two that covered an $\sim 4$ to $5 \mathrm{~mm}$ in diameter area. These spots were easily wiped away with a paper towel as the vessels were cleaned. At the end of the 28 -day tests, very small bumps $(<1 \mathrm{~mm})$ were observed on the top surface only of both samples. With a magnifying glass, these bumps were seen as clear gel-like protrusions from the sample.

At the completion of the test (after a total of 90 days in water), sample ED-SA3-D-6 had white, gellike protrusions covering the top surface of the sample. There appeared to be swelling around some of the cracks on sample ED-SA3-C-1. An estimated 4 to 5 dozen white, snowflake-like particles $\sim 1$ to $2 \mathrm{~mm}$ in diameter were floating on the solution surface of both samples. Photos at the bottom of Figure 4.1 show some of the distinct cracks, surface precipitates, and in ED-SA3-C-1, some of the surface swelling.

Table 4.6 shows the LI results obtained from these tests. It appears from these results that both the Ceramicrete and the DuraLith met the leachability index criteria for the $\mathrm{Na}$ in all of the tests. DuraLith appears to have met the Re LI target where Ceramicrete was below it with 7 instead of 9. However, it appears that all of the samples were below the iodine LI target of 11. The actual LI for I with the Ceramicrete samples could not be determined exactly as the iodine concentration was below the analytical detection limits. Therefore, the detection limit was used as it would provide the minimum LI that could be obtained for those samples. CH2MHill conducted 7-day ANS 16.1 tests with Ceramicrete and HSW spiked to concentrations of $0.1 \mathrm{~g} / \mathrm{L}$ in Re and I. At these higher concentrations, they reported leachability indices of 11.2 for iodine, 12.7 for rhenium, and 7.1 for sodium.

Table 4.6. ANSI/ANS 16.1 Testing Results After 90 Days

\begin{tabular}{||l|c|c|c|c|c||}
\hline \hline Sample ID & & & Na & Re & I \\
LI & Sample Material & Waste Type & LI \\
\hline Performance Targets & & & $>6.0$ & $>9.0$ & $>11.0$ \\
\hline HSN/NS 102005/6 & Ceramicrete & HSW & 8.08 & 7.02 & $>3.60$ \\
\hline HSN/NS 102405/21 & Ceramicrete & HSW & 8.20 & 7.36 & $>3.60$ \\
\hline SBN/NS 101405/15 & Ceramicrete & SBW & 7.59 & 7.41 & $>5.55$ \\
\hline SBN/NS 101505/16 & Ceramicrete & SBW & 7.56 & 7.42 & $>5.54$ \\
\hline VSL/HSW TB-9R3-B-S-3 & DuraLith & HSW & 8.61 & 10.59 & 4.12 \\
\hline VSL/HSW TB-9R3-E-S-5 & DuraLith & HSW & 8.59 & 10.18 & 2.37 \\
\hline VSL/SBW ED-SA3-D-6 & DuraLith & SBW & 8.34 & 9.62 & 4.65 \\
\hline VSL/SBW ED-SA3-C-1 & DuraLith & SBW & 7.74 & 9.88 & 3.93 \\
\hline
\end{tabular}




\subsection{Compressive Strength Results}

Both irradiated and as-received samples were tested for compressive strength to determine the effect of radiation on the stability of the sample. Table 4.7 summarizes the compressive strength of each specimen. These results show that the radiation had essentially no effect on the compressive strength of the specimens.

Table 4.7. Compressive Strength of Each Specimen

\begin{tabular}{|c|c|c|c|c|c|}
\hline Sample ID & $\begin{array}{l}\text { Sample } \\
\text { Material }\end{array}$ & Waste Type & Irradiated? & $\begin{array}{c}\text { Compressive } \\
\text { Strength (MPa) }\end{array}$ & $\begin{array}{l}\text { Compressive } \\
\text { Strength (psi) }\end{array}$ \\
\hline HSN/NS-101705-2 & Ceramicrete & HSW & Yes & 33.9 & 4920 \\
\hline HSN/NS-102105-11 & Ceramicrete & HSW & Yes & 34.6 & 5020 \\
\hline \multirow{3}{*}{ HSN/NS-102105-12 } & Ceramicrete & HSW & Yes & 35.4 & 5130 \\
\hline & & Mean & & 34.6 & 5020 \\
\hline & & Std Dev & & 0.8 & 105 \\
\hline HSN/NS-102105-10 & Ceramicrete & HSW & No & 39.3 & 5700 \\
\hline HSN/NS-102205-18 & Ceramicrete & HSW & No & 32.2 & 4670 \\
\hline \multirow[t]{3}{*}{ HSN/NS-102505-22 } & Ceramicrete & HSW & No & 29.2 & 4230 \\
\hline & & Mean & & 33.6 & 4870 \\
\hline & & Std Dev & & 5.2 & 752 \\
\hline SBN/NS-100805-2 & Ceramicrete & SBW & Yes & 35.9 & 5210 \\
\hline SBN/NS-101605-19 & Ceramicrete & SBW & Yes & 30.2 & 4380 \\
\hline \multirow[t]{3}{*}{ SBN/NS-101605-20 } & Ceramicrete & SBW & Yes & 35.4 & 5140 \\
\hline & & Mean & & 33.8 & 4910 \\
\hline & & Std Dev & & 3.2 & 461 \\
\hline SBN/NS-101005-4 & Ceramicrete & SBW & No & 33.3 & 4830 \\
\hline SBN/NS-101605-22 & Ceramicrete & SBW & No & 35.9 & 5210 \\
\hline \multirow[t]{3}{*}{ SBN/NS-101605-23 } & Ceramicrete & SBW & No & 37.5 & 5440 \\
\hline & & Mean & & 35.6 & 5160 \\
\hline & & Std Dev & & 2.1 & 307 \\
\hline HSW-TB-9R3-C-S-4 & DuraLith & HSW & Yes & 38.2 & 5540 \\
\hline HSW-TB-9R3-C-S-5 & DuraLith & HSW & Yes & 22.7 & 3290 \\
\hline \multirow[t]{3}{*}{ HSW-TB-9R3-D-S-4 } & DuraLith & HSW & Yes & 26.5 & 3850 \\
\hline & & Mean & & 29.1 & 4230 \\
\hline & & Std Dev & & 8.1 & 1171 \\
\hline HSW-TB-9R3-C-S-3 & DuraLith & HSW & No & 25.3 & 3670 \\
\hline HSW-TB-9R3-D-S-5 & DuraLith & HSW & No & 32.1 & 4650 \\
\hline \multirow[t]{3}{*}{ HSW-TB-9R3-E-S-4 } & DuraLith & HSW & No & 25.1 & 3640 \\
\hline & & Mean & & 27.5 & 3990 \\
\hline & & Std Dev & & 4.0 & 578 \\
\hline ISW-ED-SA3-B-3 & DuraLith & SBW & Yes & 29.0 & 4210 \\
\hline ISW-ED-SA3-D-1 & DuraLith & SBW & Yes & 23.5 & 3410 \\
\hline \multirow[t]{3}{*}{ ISW-ED-SA3-E-6 } & DuraLith & SBW & Yes & 25.6 & 3720 \\
\hline & & Mean & & 26.0 & 3780 \\
\hline & & Std Dev & & 2.8 & 400 \\
\hline ISW-ED-SA3-B-6 & DuraLith & SBW & No & 27.7 & 4020 \\
\hline ISW-ED-SA3-C-5 & DuraLith & SBW & No & 29.4 & 4260 \\
\hline \multirow[t]{3}{*}{ ISW-ED-SA3-E-1 } & DuraLith & SBW & No & 22.6 & 3270 \\
\hline & & Mean & & 26.6 & 3850 \\
\hline & & Std Dev & & 3.5 & 515 \\
\hline
\end{tabular}




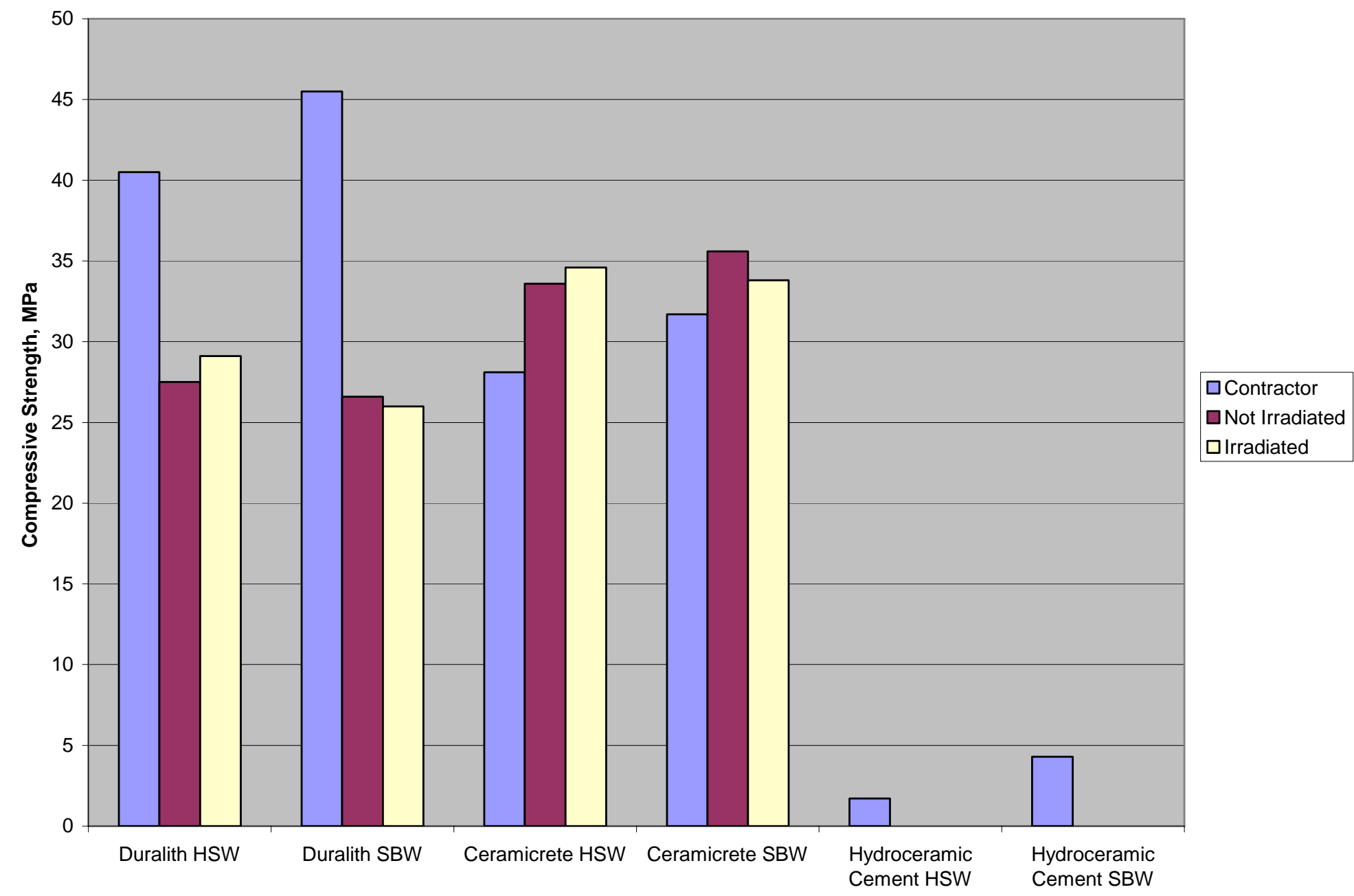

Figure 4.3. Comparison of Mean Compressive Strength Measurements on Waste Forms 
Figure 4.3 shows a comparison of the compressive strength measurements by the contractors before the test specimens were sent to PNNL and the compressive strength measurements of the as-received and irradiated specimens, both measured after the irradiations. The figure shows that the DuraLith and Ceramicrete easily meet the 3.45-MPa compressive strength requirements. It also shows that there is no apparent impact from the irradiation. It is not clear why there is a difference in the compressive strength measurements between VSL and PNNL. Further study would be needed to determine if the difference is caused by changes over time or by laboratory-to-laboratory variability.

The load and displacement of each specimen were also measured during the test, and these results are shown in Figure 4.4 to Figure 4.7. These plots show some variation between the samples, but the variation does not appear to be related to the exposure to radiation.

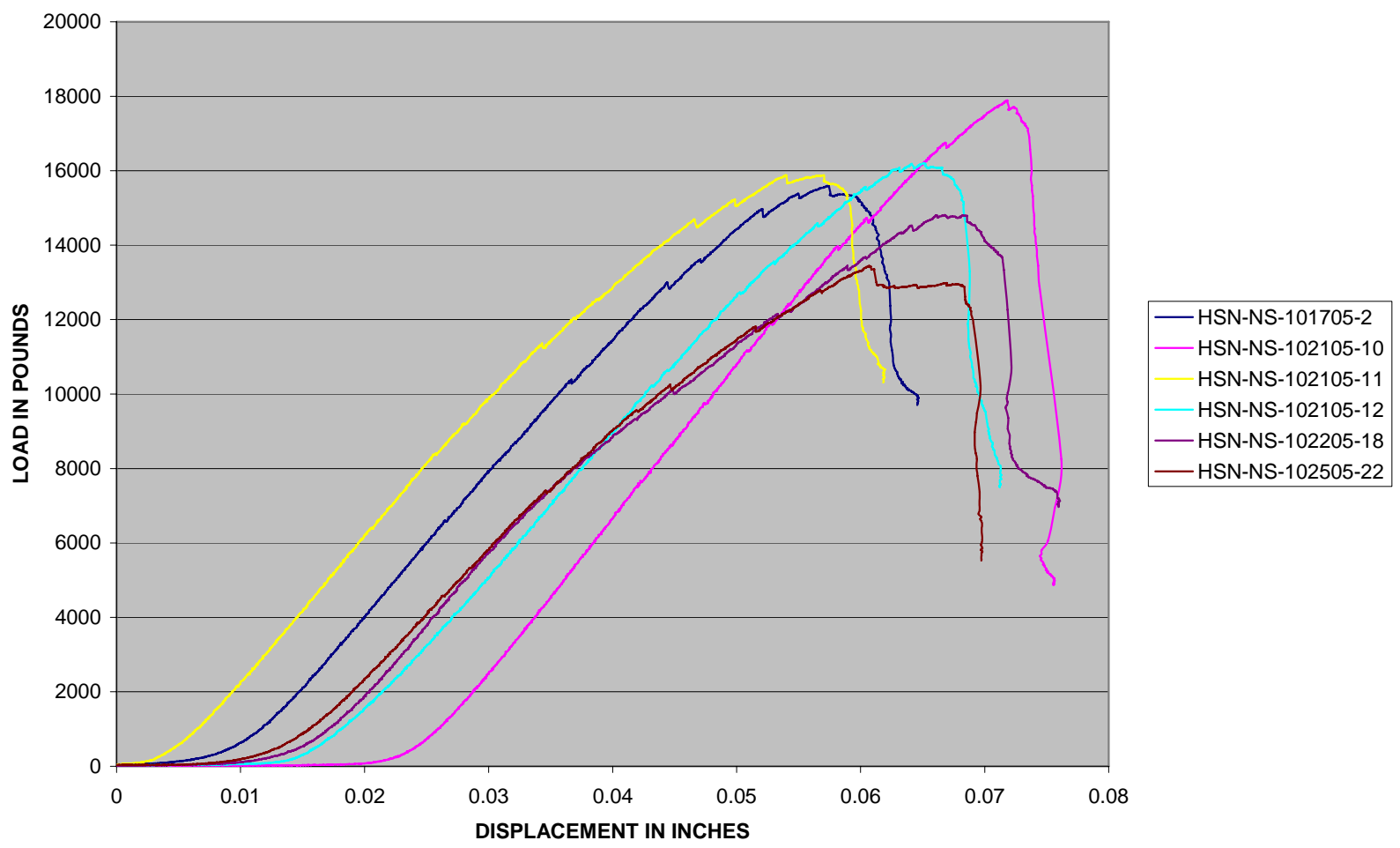

Figure 4.4. Ceramicrete HSW Sample Compression Results 


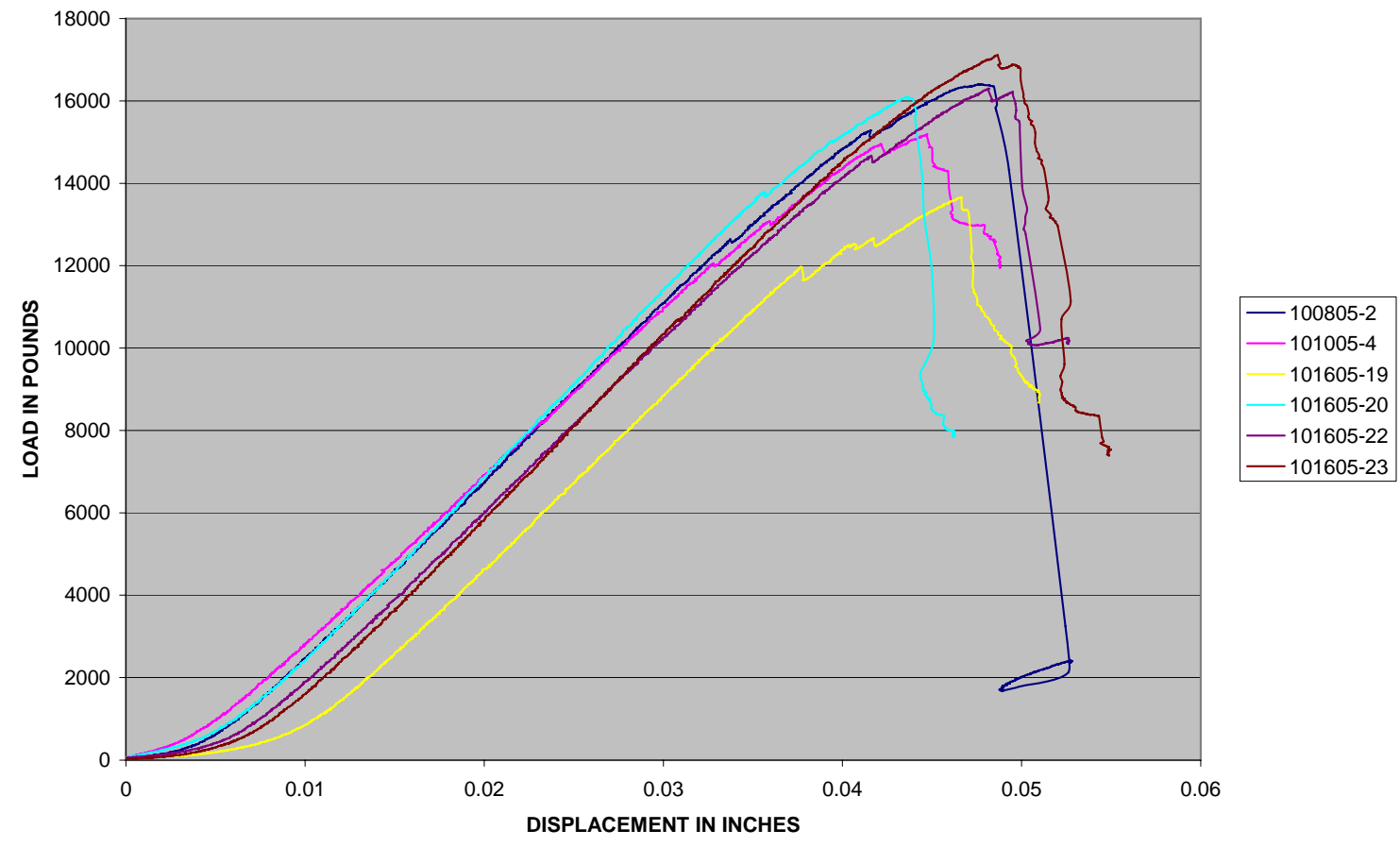

Figure 4.5. Ceramicrete SBW Sample Compression Results

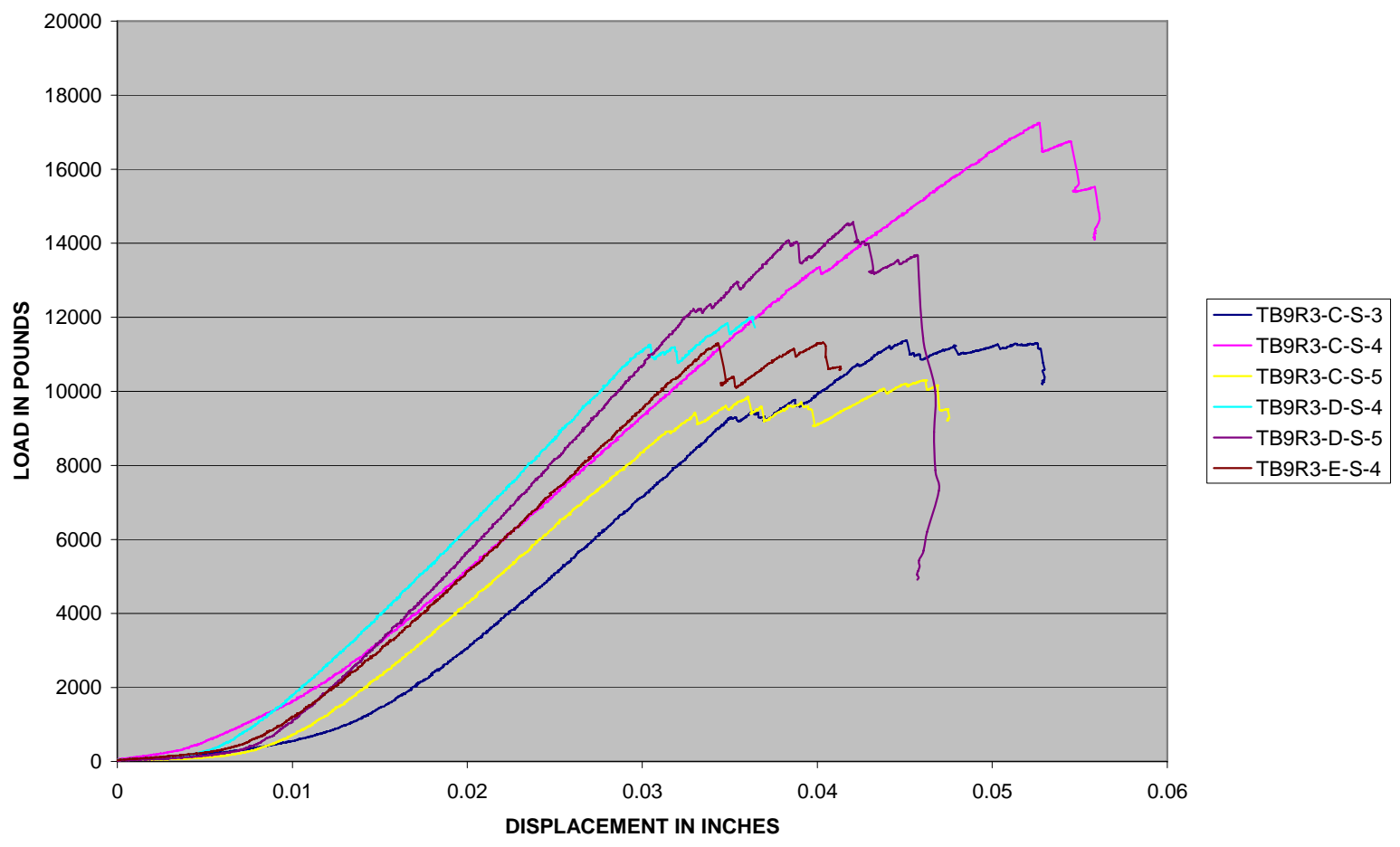

Figure 4.6. DuraLith HSW Sample Compression Results 


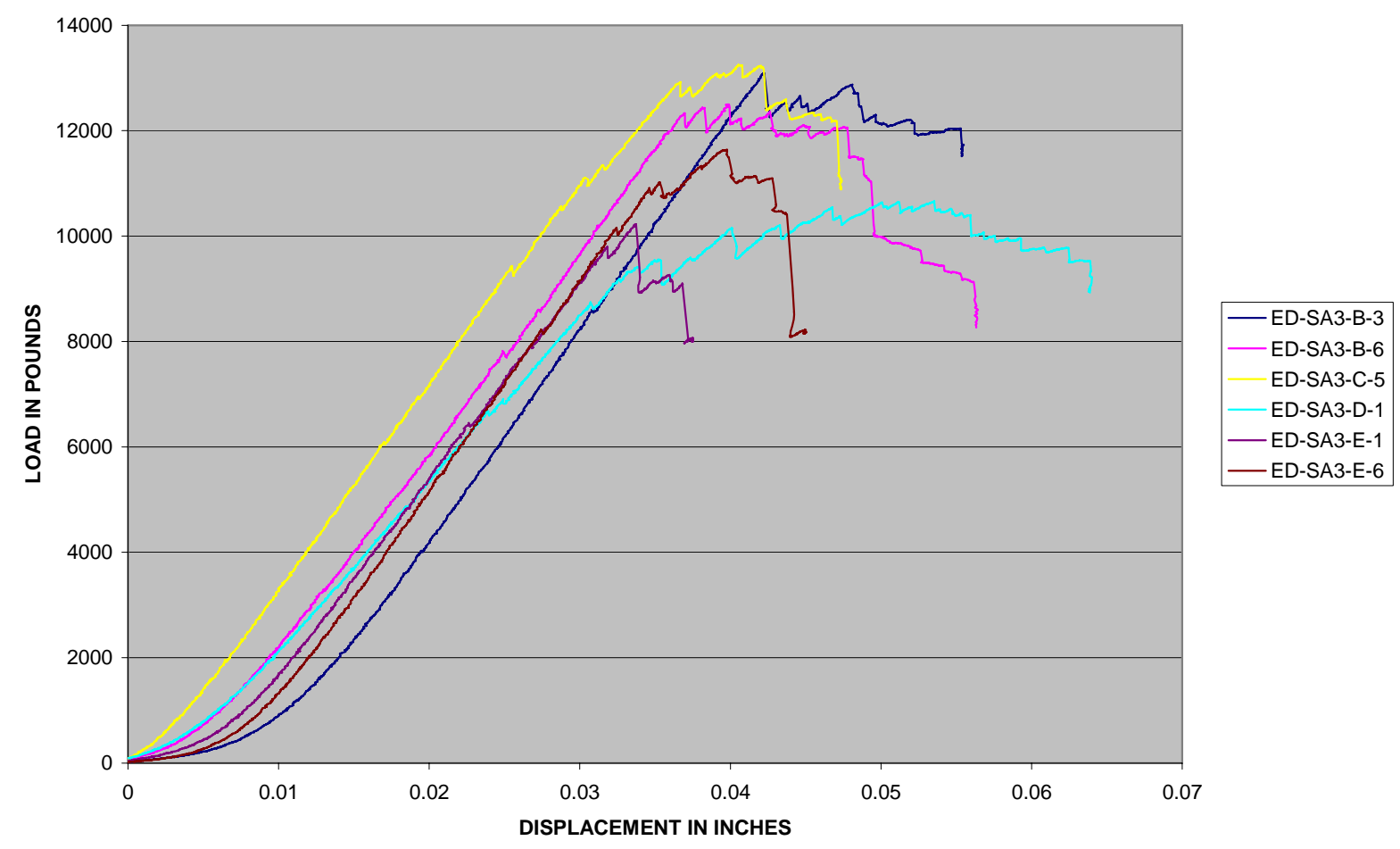

Figure 4.7. DuraLith SBW Sample Compression Results

The Ceramicrete samples appeared to fail by cracking. The cylinders stayed intact except for a few small pieces for the HSW samples (Figure 4.8, top row). The SBW samples (Figure 4.8, second row) appeared to fracture a little more with pieces of the cylinder breaking off.

The DuraLith samples seemed to show larger failure by fracturing with large pieces falling off of the cylinder. The HSW samples (Figure 4.8, third row) appeared to fracture vertically, whereas the SBW samples (Figure 4.8, bottom row) appeared to fracture throughout. 


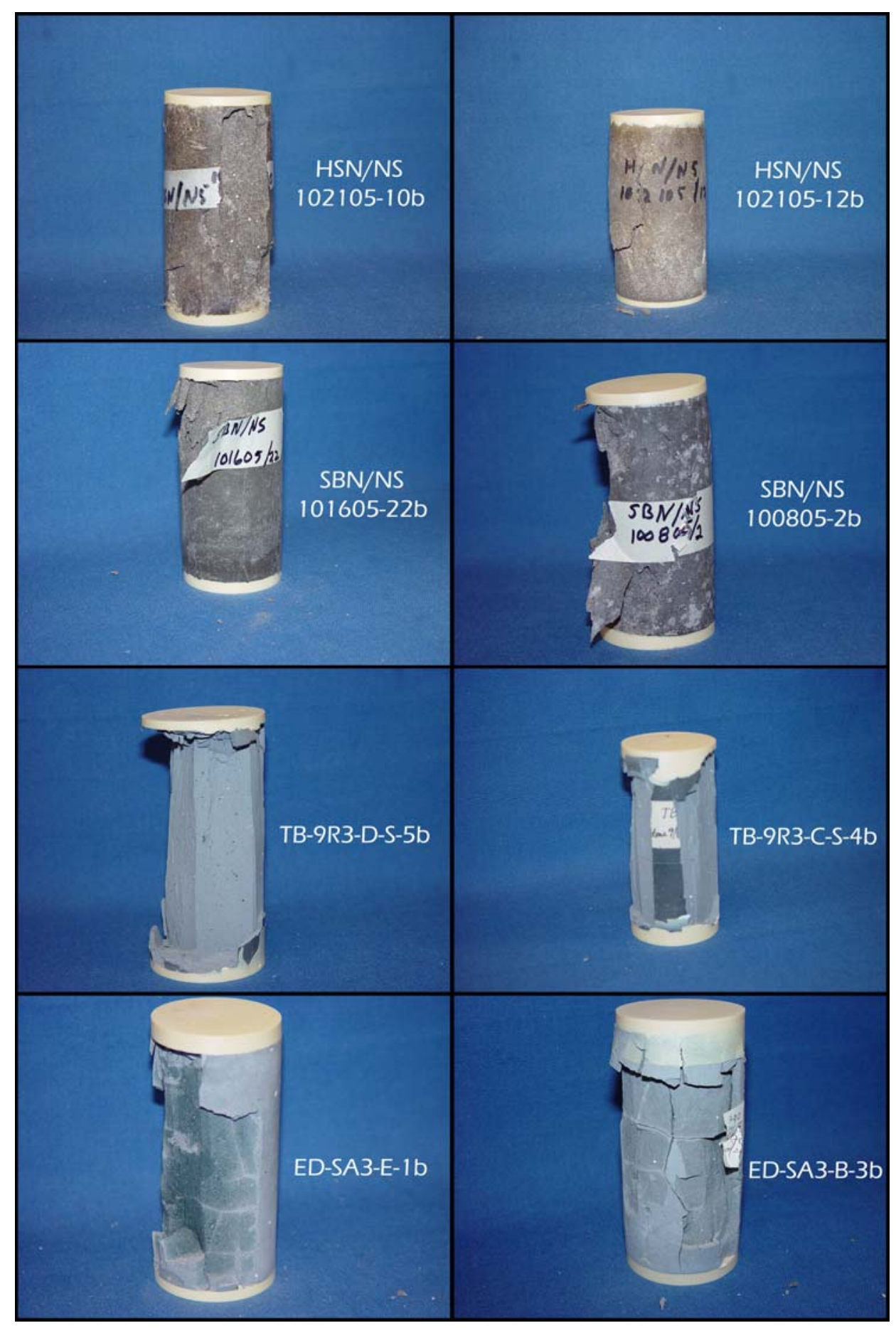

Figure 4.8. Test Specimens after Compression Testing

(Samples on the left were as-received and samples on the right were irradiated. The top four photos are for Ceramicrete, and the bottom four photos are for DuraLith. HSW specimens are in rows 1 and 3, and SBW specimens are in rows 2 and 4.) 


\subsection{Discussion and Conclusions}

\subsection{Evaluation of Waste Forms}

The next sections review the results of the characterization of the alkali-aluminosilicate hydroceramic cement, Ceramicrete phosphate-bonded ceramic, and DuraLith alkali-aluminosilicate geopolymer. It is acknowledged that the nature of the contracts limited the opportunity to develop and optimize the waste forms for the Hanford secondary waste simulant and the Idaho sodium-bearing waste simulants provided to the contractors. Thus, the results can best be described as providing a proof-of-principle and as helping to identify where additional work is needed should a decision be made to pursue these waste forms further.

\subsubsection{Compressive Strength}

The three waste forms selected for this study were subjected to compressive strength testing on the as-formed material by the contractors providing the waste forms. Ceramicrete phosphate-bonded ceramic and DuraLith alkali-aluminosilicate geopolymer easily met the $3.45 \mathrm{MPa}$ (500 psi) requirements in proposed secondary waste-disposal requirements. The alkali-aluminosilicate hydroceramic cement with the HSW did not meet the compressive strength requirements, and the hydroceramic cement with the SBW did not consistently meet the compressive-strength requirements. PNNL followed with testing of the Ceramicrete and DuraLith waste forms after irradiation to $1 \times 10^{8} \mathrm{rad}$. The PNNL testing did not show any impact due to the irradiation with as-received and irradiated specimens having essentially the same compressive strength when tested after the irradiation. It should be noted that, although not required by their contract, $\mathrm{CH} 2 \mathrm{MHill}$ did conduct freeze/thaw thermal cycling on the Ceramicrete. Freeze/thaw thermal cycling testing is recommended by the Nuclear Regulatory Commission (NRC) for proposed lowlevel waste forms (NRC 1991). Though the compressive strength was still 4 times the $3.45 \mathrm{MPa}$ limit, they saw a $50 \%$ decrease in the compressive strength as a result of the thermal cycling. This could become a concern if the waste form must retain $75 \%$ of its original strength after testing. Also, it is not clear why there is a difference in the compressive-strength measurements between VSL and PNNL for the DuraLith forms. Further study would be needed to determine if the difference is caused by changes over time or by laboratory-to-laboratory variability. Finally, it is recommended, based on the appearance of the waste forms after the ANS 16.1 leachability index testing, that the compressive strength of the waste forms be tested after immersion in water as recommended by the NRC.

\subsubsection{Toxicity Characteristic Leaching Procedure}

The TCLP addresses the hazardous metal content in the wastes and is used to meet Land Disposal Restrictions (40 CFR 268). Ceramicrete, DuraLith, and the hydroceramic cement waste forms were tested by the contractors for the silver, cadmium, chromium, lead, and mercury included in the HSW and SBW waste simulants. The Ceramicrete and DuraLith waste forms with the HSW and SBW simulants all met the universal treatment standard concentration limits in 40 CFR 268.48. The hydroceramic cement was only tested with the SBW simulant and did not meet the limits for cadmium and mercury. 


\subsubsection{Waste Loading}

Waste loading for the HSW was on the order of 8 weight percent on a dry basis or 26 to 31 weight percent on a wet basis for the Ceramicrete and DuraLith waste forms. For the SBW, the waste loading was 23 weight percent on a dry basis (47 weight percent wet basis) for the Ceramicrete and 9 weight percent on a dry basis ( 29 weight percent wet) for the DuraLith. This evaluation had no specific requirements for waste loading. Both contractors stated that there were opportunities to improve the waste loading given time and resources to optimize the formulations. Particularly for the HSW, the solids loading is relatively low, and waste loading could be improved just by reducing the water content of the wastes. This would require careful consideration of the flowsheets to verify that an evaporation step does not introduce yet another secondary waste stream requiring treatment.

\subsubsection{Product Consistency Test}

The PCT was developed for glass waste forms and was included in the testing program for this evaluation to provide a suite of tests for testing potential waste forms identified through the solicitation process. PNNL conducted the PCT on the Ceramicrete and DuraLith waste forms provided by the contractors. Using the standard sample preparation process, including washing the crushed and sieved samples with water and ethanol, there was evidence that the samples may be dissolving or otherwise breaking up during the wash step before the test itself was started. To address this issue, the standard crushed samples were washed with acetone, and a larger particle size was also tested. It must be noted that there are concerns that the acetone may also impact the test results. The PCT results are provided in this report for completeness. However, significant work is necessary to understand the waste-form behavior in the PCT and to interpret the results with respect to waste-form performance in a disposal facility.

\subsubsection{ANSI/ANS 16.1 Leachability Index Test}

The ANSI/ANS 16.1 test is typically used on waste forms such as cements where the release of contaminants is assumed to be controlled by diffusion processes through the waste form. The leachability index is related to the diffusion process - the higher the leachability index, the slower the release. As with the PCT, the relevance of the leachability index procedure must be demonstrated for the Ceramicrete and DuraLith forms tested here. Nevertheless, the stabilized secondary-waste-form preliminary requirements in place at the time of the solicitation state a requirement that the waste form have a sodium leachability index greater than 6.0 when tested for 90 days in deionized water. Further, it identified performance targets for iodine and technetium: an iodine-129 leachability index greater than 11.0 and a technetium-99 leachability index greater than 9.0.

Both the Ceramicrete and the DuraLith waste forms easily exceeded the minimum sodium leachability index. For the HSW, the Na leachability index was above 8.0 for the two waste forms, and for SBW, the Na leachability index was above 7.5. The DuraLith waste form was successful in bettering the leachability index for technetium with rhenium as a surrogate for the Tc for both waste simulants. However, it did not meet the target index for iodine. The Ceramicrete did not meet the target for technetium in the PNNL testing, and no iodine was detected in the leachate, so only greater-than values could be estimated based on the detection limits. CH2MHill did conduct a 7-day ANS-16.1 on Ceramicrete prepared from the HSW spiked with Re and I at concentrations approximately 820 and 271 times the nominal simulant concentrations. They reported leachability indices of better than 11.0 at these higher spike levels and presumably better analytical sensitivity. Thus, there is a discrepancy in the results 
that needs resolution. Should a decision be made to further pursue either of these waste forms, it is recommended that the ANS-16.1 test be conducted on optimized waste forms with iodine and technetium concentrations at some spiked level that would reduce the analytical uncertainty in the leach-solution analyses. It is important that the spike level not be so high that the waste forms require quantities of additives to sequester these nuclides that would unduly impact the composition of the waste forms.

The ANS-16.1 test procedure was particularly interesting for what it revealed about each waste form when immersed in water. Specifically, 1) the swelling and cracking of the Ceramicrete prepared with the HSW, 2) the $\mathrm{Na}_{2} \mathrm{HPO}_{4}$ phase that formed on the surface of the Ceramicrete prepared with the SBW, 3) the cracking and breakup of the DuraLith prepared with the HSW, and 4) the cracking of the DuraLith prepared with the SBW are worth noting. Discussions with CH2MHill and VSL led to the conclusion that these observed behaviors can be corrected by adjustments to the recipes or a formulation developed for the specific waste steams. Because of the limited time and resources provided through the contract for this work, there was insufficient time to do more than a few screening tests to select the recipes for the tests.

\subsubsection{Summary Evaluation}

Ceramicrete phosphate-bonded ceramic and DuraLith alkali-aluminosilicate geopolymer show potential as low-temperature waste forms for Hanford Secondary Wastes and Idaho sodium-bearing waste. Both met TCLP, compressive strength, and $\mathrm{Na}$ leachability index requirements. The alkalialuminosilicate hydroceramic cement did not meet the TCLP and compressive-strength requirements and therefore does not appear to be a viable candidate for low-temperature immobilization of these wastes. This is does not imply that hydroceramic cements may not provide acceptable waste forms when prepared under hydrothermal conditions. The ANSI/ANS 16.1 immersion test revealed formulation issues for both the Ceramicrete and DuraLith that will need to be addressed. The effectiveness of the Re (Tc) and I immobilization was not easily demonstrated at the expected low waste concentrations.

\section{$5.2 \quad$ Next Steps}

These Ceramicrete and DuraLith technologies are at different stages of maturity in waste-form development and optimization, process development and demonstration, and waste-form characteristics to support disposal-system performance assessments. They share common needs should a decision be made to develop these low-temperature immobilization waste forms further.

- Address the formulation issues identified through the ANSI/ANS 16.1 testing and perhaps also in the PCT testing.

- Using waste simulants spiked with higher concentrations of I and Re, determine whether the waste forms can achieve sufficient reduction in the release of I and Tc.

- Based on observations from ANSI/ANS 16.1 testing and contractor thermal cycling tests on Ceramicrete, expand compressive strength testing to include impacts of thermal cycling and immersion in water.

- Optimize the quantities of binder materials to improve waste loading. If acceptable, this may include removal of water to concentrate the wastes to be immobilized.

- Examine other binder materials that may be less costly. 
- Demonstrate the long-term effectiveness of sequestering agents added to reduce the mobility of iodine and technetium in the wastes.

- Demonstrate preparation of the waste forms on a production scale.

- Determine long-term waste-form performance characteristic evaluations to support disposalsystem performance assessments. 


\subsection{References}

40 CFR 268. 2004. "Land Disposal Restrictions." Code of Federal Regulations, U.S. Environmental Protection Agency, Washington, D.C.

American National Standards Institute/American Nuclear Society (ANSI/ANS). 1986. American National Standard Measurement of the Leachability of Solidified Low Level Radioactive Waste by Short Term Procedure. ANSI/ANS 16.1, Washington D.C.

American Society for Testing and Materials (ASTM). 2005. Compressive Strength of Cylindrical Concrete Specimens. ASTM C-39, West Conshohocken, PA.

American Society for Testing and Materials (ASTM). 2002. Standard Test Methods for Determining Chemical Durability of Nuclear, Hazardous, and Mixed Waste Glasses: The Product Consistency Test (PCT). ASTM C-1285, West Conshohocken, PA.

Babad H, and DM Strachan. 1980. "Method for Immobilizing Radioactive Iodine.” U.S. Patent $4,229,317$.

Davidovits J. 1994a. "Process for Obtaining a Geopolymeric Aluminosilicate and Products Thus Obtained." U.S. Patent 5,342,595.

Davidovits J. 1994b. "Method for Obtaining a Geopolymeric Binder Allowing to Stabilize, Solidify, and Consolidate Toxic Waste Materials.” U.S. Patent 5,349,118.

Davidovits J. 1996. Method for Obtaining a Geopolymeric Binder Allowing to Stabilize, Solidify, and Consolidate Toxic Waste Materials. U.S. Patent 5,539,140.

Ebert WL, and SF Wolf. 1999. Round-Robin Testing of a Reference Glass for Low-Activity Waste Forms. Argonne National Laboratory, Argonne, IL.

Perera DS, Z Aly, ER Vance, and M Mizumo. 2005. "Immobilization of Pb in a Geopolymer Matriz." J. Am. Cream. Soc. 88(9):2586-2588.

Siemer DD, B Scheetz, MW Grutzeck, and D Roy. 2002. "Cementitious Solidification of DOE's Legacy Reprocessing Waste." Spectrum 2002, $9^{\text {th }}$ Biennial International Conference on Nuclear and Hazardous Waste Management, Reno, NV.

U.S. Department of Energy (DOE). 1999. Stabilization Using Phosphate Bonded Ceramics, Innovative Technology Summary Report. DOE/EM-0486, Washington D.C.

U.S. Environmental Protection Agency (EPA). 1997. Test Methods for Evaluating Solid Waste, Physical/Chemical Methods. SW 846 as amended, Washington, D.C.

U.S. Nuclear Regulatory Commission (NRC). 1991. Technical Position on Waste Form, Rev. 1, LowLevel Waste. Division Management Branch, Office of Nuclear Material Safety and Safeguards, Washington, D.C. 
Wagh AS, and D Singh. 1997. "Method for Stabilizing Low-Level Mixed Wastes at Room Temperature." U. S. Patent 5,645,518 
Attachment A-Evaluation Criteria for Proposals Received 


\section{Attachment A: Evaluation Criteria For Proposals Received}

1. Technical Merit

a. Degree to which proposed immobilization technology offers potential advantages and benefits over vitrification and grout immobilization technologies for intended waste streams

b. Degree to which the proposed immobilization technology is based on sound scientific and engineering principles

c. Feasibility of the proposed immobilization technology and level of technologydevelopment maturity

d. Feasibility of deployment within 1- to 2-year time frame

e. Degree to which prior work relates to the proposed application

f. Degree to which the proposed immobilization technology represents a breadth of methods, approaches, or application of differing immobilization technologies

2. Technical Approach

a. Degree to which offeror demonstrates an understanding of radioactive waste immobilization problems and issues

b. Adequacy and feasibility of offeror's technical approach to preparing and testing simulated waste forms

c. Reasonableness and adequacy of the proposed project schedule

d. Degree to which offeror demonstrates understanding of safety- and health-related issues of proposed technology and scope of work to be performed

3. Capabilities, Experience, Facilities, and Equipment

a. Qualifications and experience of technical and management staff and subcontractors

b. Adequacy and availability of proposed equipment, materials, and facilities

Price

Weight 30\%

The offeror with the lowest overall price will receive the maximum number of price points. The number of points to be received by an offeror submitting a higher overall price will be in accordance with that higher price's relationship to the lowest price. 


\section{Attachment B-Noah Technologies Simulant Reports}




\title{
Attachment B-Noah Technologies Simulant Reports
}

\author{
PREPARATION AND ANALYSES OF HANFORD SCRUBBER SOLUTION SIMULANT AND \\ STARTING MATERIALS FOR BATTELLE \\ P/O No. 15077
}

Kelly Sellers

Chief Chemist

Noah Technologies Corp.

April 4, 2005

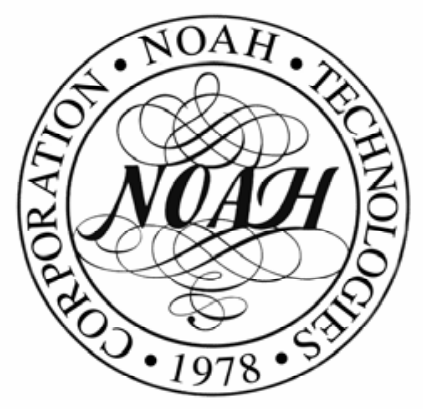

B. 1 


\title{
PREPARATION AND ANALYSES OF HANFORD SCRUBBER SOLUTION SIMULANT AND STARTING MATERIALS FOR BATTELLE
}

\author{
By Kelly Sellers
}

\section{SUMMARY}

The Hanford Scrubber Solution Simulant was prepared to match the composition in Table 2 of the Statement of Work sent with Purchase Order No. 15077. All starting material masses were calculated to deliver the target concentrations of each analyte. Table 1 summarizes the expected analyte molar concentrations calculated using the actual weights of the compounds contained in the reagents. The analytical results of the analysis using Inductively Coupled Plasma (ICP) spectroscopy for metals, Ion Chromatography (IC) for anions and $\mathrm{pH}$ and titration for hydroxide concentration of the simulant are contained in Table 2. The analyses of the starting materials follow the tables.

\section{PREPARATION}

Into a 120 gallon mixing drum $122.0 \mathrm{~kg}$ of deionized water was added and $23.0 \mathrm{~kg}$ of Sodium Carbonate and $600 \mathrm{~g}$ of Sodium Hydroxide was dissolved.

In a stainless steel beaker $123 \mathrm{~g}$ of Sodium Hydroxide was mixed until dissolved. Using extreme caution, $67.1 \mathrm{~g}$ of powdered Aluminum metal was slowly added to the solution while mixing until all was added and the solution was clear. This was then added to the 120 gallon mixing drum.

In another stainless steel beaker $568 \mathrm{~g}$ of Ammonium Acetate was dissolved in $1.0 \mathrm{~kg}$ of deionized water. Into this solution $8.45 \mathrm{~g}$ of Silver Nitrate was added. The beaker was covered to exclude light. Initially a white precipitate had formed and was mixed until all the solids had gone into solution. This was then added to the 120 gallon mixing drum.

To the bulk solution the following was added:

$1.00 \mathrm{~kg} \quad$ Ammonium Acetate

$301 \mathrm{~g} \quad$ Ammonium Nitrate

$111 \mathrm{~g} \quad$ Ammonium Hydroxide solution

$11.2 \mathrm{~g} \quad$ Lead Nitrate

$33.24 \mathrm{~g}$ Chromium Nitrate, Nonahydrate, $77 \%$ solution

$25.25 \mathrm{~m} \ell$ Rhenium analytical standard, $1000 \mathrm{ppm}$

$83.17 \mathrm{m \ell}$ Iodine analytical standard, $1000 \mathrm{ppm}$

$108.80 \mathrm{~m} \ell$ Mercury analytical standard, $1000 \mathrm{ppm}$

$35.57 \mathrm{m \ell}$ Cadmium analytical standard, 10,000 ppm

The resulting solution was mixed thoroughly for six hours and a sample was removed for analysis. This analysis indicated a wide range of values with the majority of the analytes approx. 15-20\% high. To bring the values in range the following was added: 
$26.0 \mathrm{~kg}$ Deionized water

$0.95 \mathrm{~g}$ Silver Nitrate dissolved in $20 \mathrm{~m} \ell$ Ammonium Hydroxide, solution

$8.5 \mathrm{~g}$ Aluminum metal dissolved in $100 \mathrm{~m} \ell$ D.I. water with $40 \mathrm{~g}$ Sodium Hydroxide

$0.03 \mathrm{~g}$ Mercury Nitrate dissolved in $10 \mathrm{~m} \ell$ D.I. water with $1 \mathrm{~m} \ell$ Nitric Acid

$6.4 \mathrm{~m} \ell$ Cadmium analytical standard, 10,000 ppm

After thorough mixing a sample was removed for analysis.

The second analysis showed all of the analytes were within the specified range.

The Product Code No. C2584, SURROGATE WASTE, Hanford Scrubber Solution Simulant for Battelle, was assigned to this product.

While mixing the single homogeneous batch, a one liter sample was pulled for submission to Pacific Northwest National Laboratory and labeled as Lot No. 144046/1.1. The first bulk shipping container was then filled for shipment to vendor no. 1 (Vitreous State Laboratory), labeled as Lot No. 144046/1.1 and a $50 \mathrm{~m} \ell$ sample was then pulled from the shipping container and labeled with the same lot number.

The second bulk shipping container was then filled for shipment to vendor no. 2 (Mississippi State University), labeled as Lot No. 144046/1.2 and a $50 \mathrm{~m} \ell$ sample was then pulled from the shipping container and labeled with the same lot number.

The third and forth smaller requested bulk shipping containers were then filled for shipment to vendor no. 3 (Argonne National Laboratory), labeled as Lot No. 144046/1.3 and a composite $50 \mathrm{~m} \ell$ sample was then pulled from the shipping containers and labeled with the same lot number. 
PREPARATION AND ANALYSES OF INEEL SODIUM BEARING WASTE SIMULANT AND STARTING MATERIALS FOR BATTELLE

P/O No. 15077

Kelly Sellers

Chief Chemist

Noah Technologies Corp.

April 1, 2005

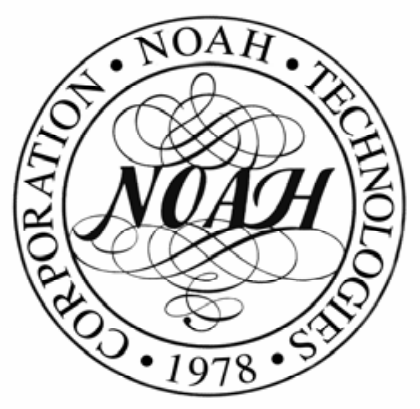




\section{PREPARATION AND ANALYSES OF INEEL SODIUM BEARING WASTE SIMULANT AND STARTING MATERIALS FOR BATTELLE}

By Kelly Sellers

\section{SUMMARY}

The INEEL Sodium Bearing Waste Simulant was prepared to match the composition in Table 1 of the Statement of Work sent with Purchase Order No. 15077. All starting material masses were calculated to deliver the target concentrations of each analyte. Table 1 summarizes the expected analyte molar concentrations calculated using the actual weights of the compounds contained in the reagents. The analytical results of the analysis using Inductively Coupled Plasma (ICP) spectroscopy for metals, Ion Chromatography (IC) for anions and $\mathrm{pH}$ and titration for proton concentration of the simulant are contained in Table 2. The analyses of the starting materials follow the tables.

\section{PREPARATION}

Into a 15 gallon mixing drum $15.0 \mathrm{~kg}$ of deionized water was added and $2.30 \mathrm{~kg}$ of Sodium Hydroxide was dissolved. Using extreme caution, $762 \mathrm{~g}$ of powdered Aluminum metal was slowly added to the solution while mixing until all was added and the solution was clear.

Into a 55 gallon mixing drum $50.0 \mathrm{~kg}$ of deionized water was added and $12.795 \mathrm{~kg}$ of Aluminum Nitrate, Nonahydrate was dissolved. To the solution $14.0 \mathrm{~kg}$ of Nitric Acid (nominally 65\%) was added while mixing until the solution was clear.

Slowly the first solution was added to the second solution while it was mixing. As the solution was added a gelatinous precipitate formed and then slowly went back into solution. The resulting solution was mixed until all solids had dissolved and the solution was clear.

While mixing, the following was added in order:

$\begin{array}{ll}13.49 \mathrm{~kg} & \text { Sodium Nitrate } \\ 1.235 \mathrm{~kg} & \text { Potassium Nitrate } \\ 1.255 \mathrm{~kg} & \text { Aluminum Sulfate, Octadecahydrate } \\ 994 \mathrm{~g} & \text { Calcium Nitrate, Tetrahydrate } \\ 827 \mathrm{~g} & \text { Iron Nitrate, Nonahydrate } \\ 318 \mathrm{~g} & \text { Magnesium Nitrate, Hexahydrate } \\ 244 \mathrm{~g} & \text { Potassium Chloride } \\ 72.6 \mathrm{~g} & \text { Boric Acid } \\ 507 \mathrm{~g} & \text { Manganese Nitrate, Hexahydrate, } 50 \% \text { solution } \\ 269 \mathrm{~g} & \text { Potassium Fluoride } \\ 24.8 \mathrm{~g} & \text { Cadmium Nitrate, Tetrahydrate } \\ 151.8 \mathrm{~g} & \text { Chromium Nitrate, Nonahydrate, } 77 \% \text { solution } \\ 78.8 \mathrm{~g} & \text { Mercury Nitrate, Dihydrate (Assayed as the Monohydrate) } \\ 49.6 \mathrm{~g} & \text { Lead Nitrate } \\ 1.08 \mathrm{~g} & \text { Potassium Iodide }\end{array}$


$67.02 \mathrm{m \ell}$ Rhenium analytical standard, $1000 \mathrm{ppm}$

$85.40 \mathrm{~m} \ell \quad$ Cerium analytical standard, $1000 \mathrm{ppm}$

$12 \mu \ell \quad$ Cesium analytical standard, $1000 \mathrm{ppm}$

The resulting solution was mixed thoroughly until all the solids had dissolved and a sample was removed for analysis. This analysis indicated the majority of the analytes were approx. $20 \%$ higher than target with iron and manganese only approx. $10 \%$ higher. The proton and nitrate concentrations were close to target.

While mixing the solution, $30 \mathrm{~g}$ of Iron Nitrate, Nonahydrate and $20 \mathrm{~g}$ of Manganese Nitrate, Hexahydrate, 50\% solution were added along with 15 liters of $2 \mathrm{M}$ Nitric Acid solution. After thorough mixing a sample was removed for analysis.

The second analysis showed all of the analytes were within the specified range with the exception of aluminum, magnesium and fluoride. An additional 4 liters of $2 \mathrm{M}$ Nitric Acid solution was added with thorough mixing and a final sample was removed for analysis.

The final analysis found all of the analytes were within the specified range.

The Product Code No. C2585, SURROGATE WASTE, INEEL Sodium Bearing Waste Simulant for Battelle, was assigned to this product.

While mixing the single homogeneous batch, a one liter sample was pulled for submission to Pacific Northwest National Laboratory and labeled as Lot No. 144057/1.1. The first bulk shipping container was then filled for shipment to vendor no. 1 (Vitreous State Laboratory), labeled as Lot No. 144057/1.1 and a $50 \mathrm{~m} \ell$ sample was then pulled from the shipping container and labeled with the same lot number.

The second bulk shipping container was then filled for shipment to vendor no. 2 (Mississippi State University), labeled as Lot No. 144057/1.2 and a $50 \mathrm{m \ell}$ sample was then pulled from the shipping container and labeled with the same lot number.

The third and forth smaller requested bulk shipping containers were then filled for shipment to vendor no. 3 (Argonne National Laboratory), labeled as Lot No. 144057/1.3 and a composite $50 \mathrm{~m} \ell$ sample was then pulled from the shipping containers and labeled with the same lot number. 


\section{Attachment C-Modified PCT Procedure}




\section{Attachment C-Modified PCT Procedure}

\section{C.1 Particle Sizing and Washing Tests}

Several different washing procedures and mesh sizes were tried to determine which offered the optimum results on both the HSW and the SBW. The standard PCT procedure of rinsing three times with DI water, ultrasonically cleaning twice with DI water for 2 minutes, and then ultrasonically cleaning with ethanol three times for 2 minutes each time was compared to cleaning with acetone by ultrasonically cleaning the samples with acetone for 2 minutes numerous times. Two different particle size ranges were tested: 0.84 to $2.00 \mathrm{~mm}(-10$ to $+20 \mathrm{mesh})$ and 75 to $150 \mu \mathrm{m}(-100$ to $+200 \mathrm{mesh})$. The -10 to $+20 \mathrm{mesh}$ particle size samples were washed with the standard PCT wash of DI water and ethanol and by acetone in place of the DI water and ethanol. Because it had already been determined that the standard PCT wash caused the -100 to +200 mesh particle size samples to dissolve, these samples were only washed with acetone.

With the SBW waste sample tested (SBN/NS 101305/6), the larger particle size sample washed with the standard PCT wash showed two cloudy DI water rinses that were slightly gray. All three of the ultrasonic ethanol washes were also cloudy and slightly gray. The $\mathrm{pH}$ of the decanted rinse solution was $\sim 8$ and cloudy with beige fines settled out covering the bottom of the decanted rinse beaker. The -10 to +20 mesh particle size sample ultrasonically cleaned for 2 minutes in acetone was not as cloudy as the standard PCT wash. Each wash with acetone was a little less cloudy until the cloudiness of the cleaning solution became constant after the fourth ultrasonic acetone cleaning. The $\mathrm{pH}$ of the decanted acetone rinse solution was between 5 and 6 with beige fines settling out to cover the bottom of the decanted rinse beaker.

The -100 to +200 mesh particle size SBW sample tested (SBN/NS 101505/16), which was washed twice for 2 minutes in an ultrasonic bath with acetone, showed a muddy-looking wash with lots of particulate in it that made it hard to decant.

The HSW waste sample tested (HSN/NS 102105/9) showed that with the -10 to +20 mesh particle size washed with the standard PCT wash, the DI water rinse was only slightly cloudy. After two washes in the ultrasonic bath for 2 minutes with DI water, it was cloudier than the initial DI water rinse and had a gray tint to it. After the first ethanol 2-minute ultrasonic wash, it was cloudy with a gray tinge. After the second ethanol 2-minute ultrasonic wash, the solution was only slightly cloudy, and after the third ethanol 2-minute ultrasonic wash, the solution was even less cloudy than the previous wash solution. The $\mathrm{pH}$ of the decanted wash solution was $\sim 9$, and the decanted wash solution was very cloudy with bright white fines settling out covering the bottom of the decanted rinse beaker. The -10 to +20 mesh particle size acetone wash solution was at least as cloudy as the standard PCT wash solution. Each wash with acetone was a little less cloudy until the cloudiness of the cleaning solution became constant after the fourth ultrasonic acetone cleaning. The $\mathrm{pH}$ of the acetone rinse solution was between 5 and 6 with beige fines settling out to cover the bottom of the decanted rinse beaker. The -100 to +200 mesh particle size sample that was ultrasonically washed twice in acetone showed a muddy looking wash solution with lots of particulate in it that made it hard to decant. 
Based on these results, it was decided to test both particle sizes and replace the rinsing and washing using DI water and ethanol with acetone.

\section{C.2 PCT Time Duration Testing}

Testing was performed to determine the ideal length of time to perform the PCT test on these waste samples. Tests lasting 20 minutes, 1 hour, 1 day, and 7 days were performed using the larger particle size for a standard glass (LRM), an HSW sample from VSL (TB-9R3-E-S-4), and an HSW sample from CH2MHill (HSN/NS 702051/9). At the end of each test, the solution conductivity was measured. Tables C. 1 and C. 2 as well as Figure C.1 show the data obtained from testing. These results indicate that the solution saturates quickly and then does not change much over time. After 1 hour, the $\mathrm{pH}$ and solution conductivity did not change much, and after 24 hours, they were essentially the same. This indicates that testing for 24 hours is plenty of time to obtain a constant result.

Based on these data, it was decided to test the larger particle size samples washed in acetone for 24 hours while testing the smaller particle size samples washed in acetone following the standard 7-day PCT test.

Table C.1. PCT Solution $\mathrm{pH}$ Over Time

\begin{tabular}{|c|c|c|c||}
\hline Sample ID & LRM & HSN/NS 702051/9 & $\begin{array}{c}\text { VSL/CUA HW } \\
\text { TB-9R3-E-S-4 }\end{array}$ \\
\hline Time (hr) & $\mathbf{p H}$ & $\mathbf{p H}$ & $\mathbf{p H}$ \\
\hline 0.3 & 7.56 & 9.58 & 11.11 \\
\hline 1.0 & 8.08 & 7.77 & 11.71 \\
\hline 24.0 & 9.20 & 10.25 & 12.00 \\
\hline 168.0 & 9.18 & 10.38 & 12.02 \\
\hline
\end{tabular}

Table C.2. PCT Solution Conductivity Over Time

\begin{tabular}{|c|c|c|c||}
\hline Sample ID & LRM & HSN/NS 702051/9 & $\begin{array}{c}\text { VSL/CUA HW } \\
\text { TB-9R3-E-S-4 }\end{array}$ \\
\hline Time (hr) & $\boldsymbol{\varepsilon}(\mathbf{m S})$ & $\boldsymbol{\varepsilon}(\mathbf{m S})$ & $\boldsymbol{\varepsilon}(\mathbf{m S})$ \\
\hline 0.3 & 0.034 & 34.5 & 13.8 \\
\hline 1.0 & 0.026 & 37.3 & 16.4 \\
\hline 24.0 & 0.154 & 51.8 & 30.6 \\
\hline 168.0 & 0.375 & 50.8 & 29.3 \\
\hline
\end{tabular}




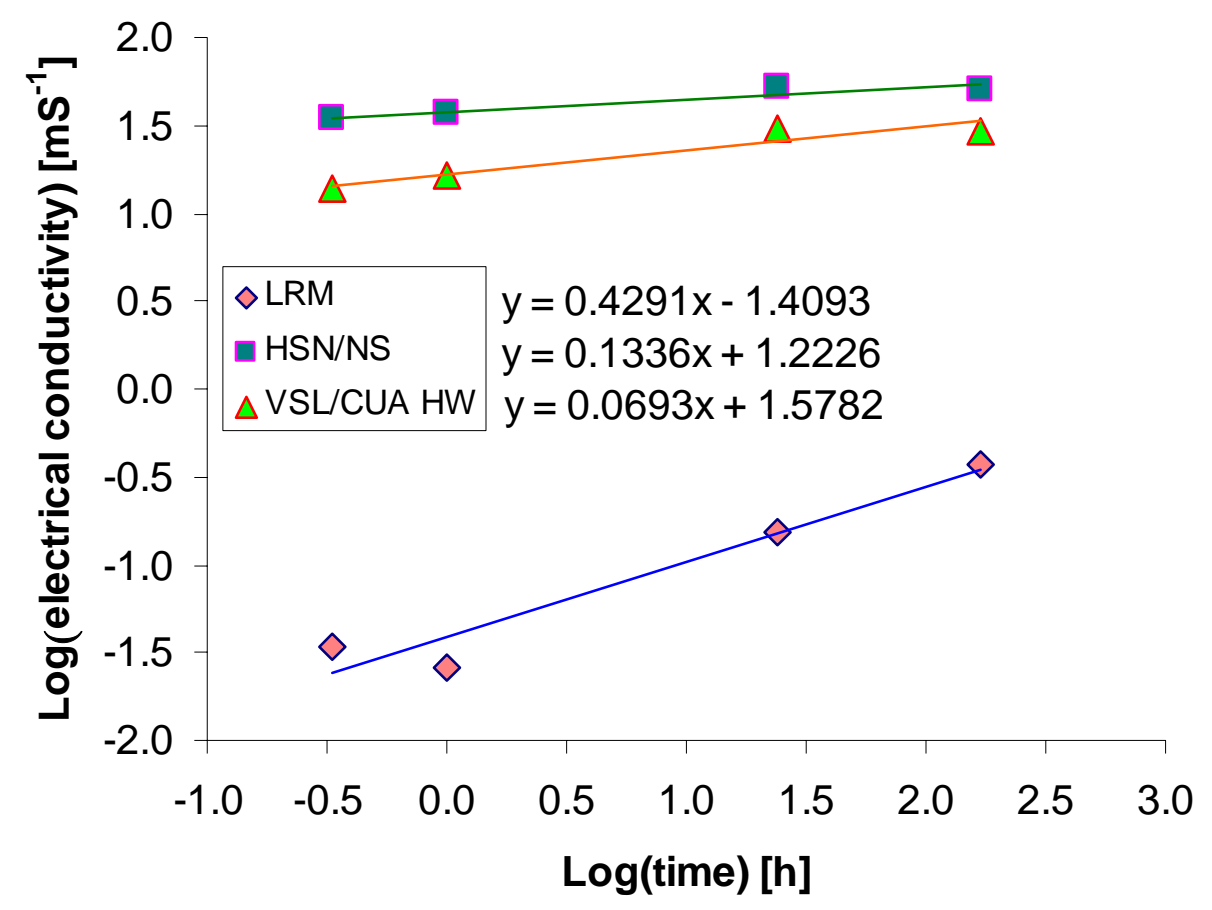

Figure C.1. PCT Solution Conductivity Versus Time

\section{C.3 Surface Area Calculation}

Waste-form particles after grinding have an ill-defined shape. In order to calculate exposed wasteform surface area from the mass of waste form used in the test, one must assume a given geometric shape. If the waste form is assumed to be spherical and the particle size distribution between the mesh sizes used is assumed to be Gaussian, an estimated surface area can be calculated. Particle size analysis of wellsieved glass samples shows that using the average diameter of the particles from the mesh sizes used introduces no significant error. The density was assumed to be $2.04 \mathrm{~g} / \mathrm{mL}$ for Ceramicrete and $1.81 \mathrm{~g} / \mathrm{mL}$ for DuraLith based on reported values from the contractors. The area (A) and volume (V) of a spherical particle are given by:

$$
\mathrm{A}=\pi \mathrm{d}^{2} \quad \text { and } \quad \mathrm{V}=(1 / 6) \pi \mathrm{d}^{2}
$$

where $d$ is the average particle diameter. The density is mass/unit volume, so the mass of an average size particle can be determined as

average particle mass $=$ density $\mathrm{x}$ volume

This enables the calculation of the number of particles per gram of crushed waste form. Each particle has a surface area as calculated from the equation above, so the total surface area in $1 \mathrm{~g}$ of waste form is found by multiplying the number of particles per gram by the area of each particle. 
Assuming cubic or tabular particle shapes imparts only an approximately $1 \%$ difference in the surface area calculation compared to assuming spherical shapes (Shade and Strachan 1986; Pine and Jantzen 1987). The calculated surface areas for $1.5 \mathrm{~g}$ of Ceramicrete material were $0.0031 \mathrm{~m}^{2}$ for the $-10,+20$ mesh and $0.040 \mathrm{~m}^{2} /$ for the $100,+200$ mesh samples. The calculated surface areas for $1.5 \mathrm{~g}$ of DuraLith material were $0.0035 \mathrm{~m}^{2}$ for the $-10,+20$ mesh and $0.045 \mathrm{~m}^{2}$ for the $100,+200$ mesh samples.

\section{C.3 References}

Pine GL, and CM Jantzen. 1987. Implications of a One-Year Basalt Weathering/Reactivity Study for a Basalt Repository Environment. U.S. DOE Report DP-1742, E.I. duPont deNemours and Co., Savannah River Laboratory, Aiken, SC.

Shade JW, and DM Strachan. 1986. "Effect of high Surface Area to Solution Volume Ratios on Waste Glass Leaching." American Ceramic Society Bulletin 65(12):1568-1573. 


\section{Attachment D-Ceramicrete Final Report}




\title{
Pacific Northwest National Laboratory Project 15259
}

Low Temperature Waste Immobilization

Performance Demonstration of Chemically Bonded Phosphate Ceramics:

Hanford Secondary Waste and Idaho Sodium Bearing Waste

\section{CH2MHILL}

\author{
9191 South Jamaica Street \\ Englewood, CO 80112 \\ e-mail: david.maloney@ch2m.com
}

\begin{abstract}
Investigators:
David Maloney, PhD—CH2M HILL Nuclear Group Michael Johnson-CH2M HILL Hanford Group, Inc.

Peter Dirkmaat-CH2M-WG-Idaho, LLC

Arun Wagh, PhD—Argonne National Laboratory

Ramkumar Natarajan-Argonne National Laboratory
\end{abstract}

Dated: February 2006 


\section{Contents}

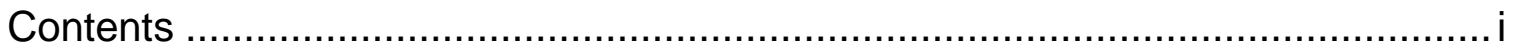

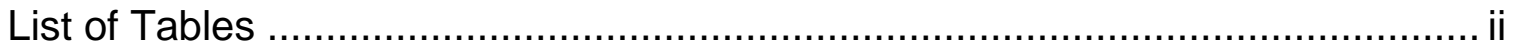

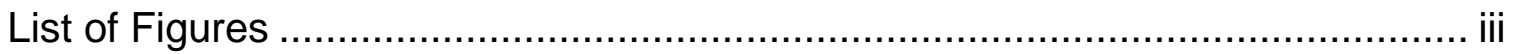

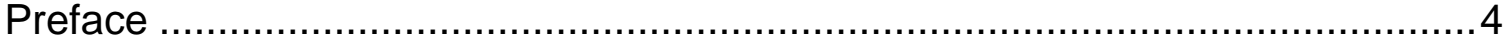

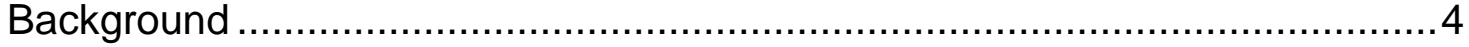

Advantages in Risk and Cost ............................................................. 4

Part I. Process Demonstration for HSW and SBW.................................... 7

I-1 Ceramic Process Fundamentals ............................................................... 7

I-2 Waste Composition and Characteristics …..........................................

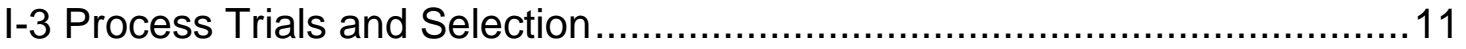

I-3.1 Neutralization of the Waste Streams ............................................12

I-3.2 Waste Stream Dewatering ......................................................... 13

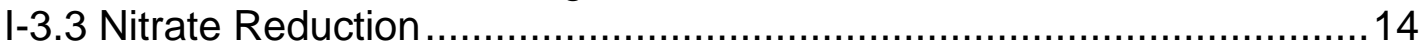

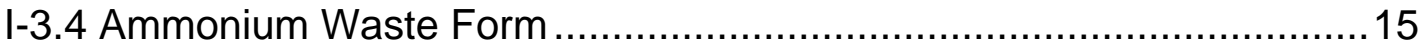

I-3.5 Incorporation of Sodium in Ceramic Mineral Binder ...........................15

I-3.6 Berlinite Waste Form ......................................................... 15

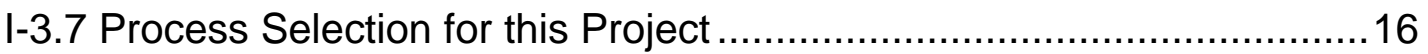

I-3.8 Addition of Reagents to Stabilize Problem Metals ............................ 17

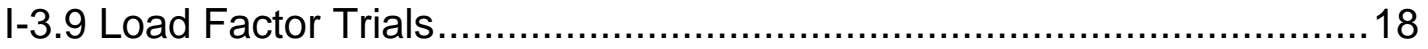

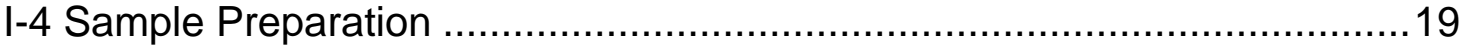

I-4.1 Method Used to Prepare Samples................................................19

I-4.2 Temperature Profile During Sample Fabrication................................23

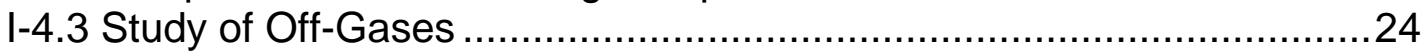

I-5 Characteristics of the Ceramic Waste Forms ........................................2

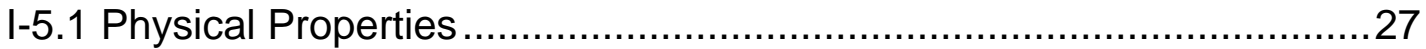

I-5.2 Leaching Performance of the Waste Forms (Spiked Waste) ...............29

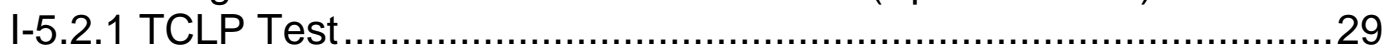

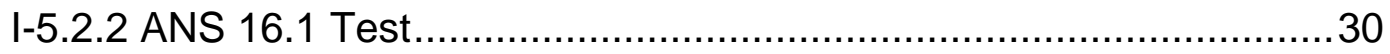

I-5.2.3 Product Consistency Test ........................................................31

I-6 Summary of Ceramic Waste Form Properties and Performance ................33

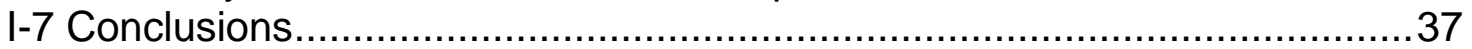

I-8 Environment, Health, Safety and Quality (EHS\&Q) Processes ..................40

I-8.1 Environment, Health and Safety ....................................................40

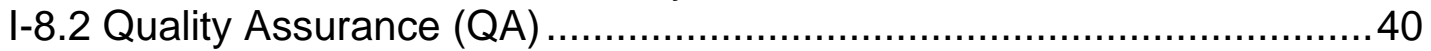

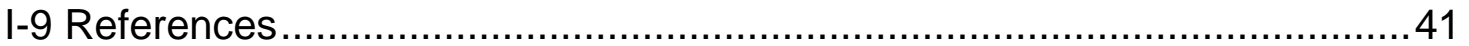

Part II. Facility Implementation Concepts for HSW and SBW ........................44

II-1 Process Description—Hanford Secondary Waste.................................. 45

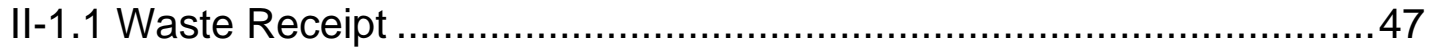

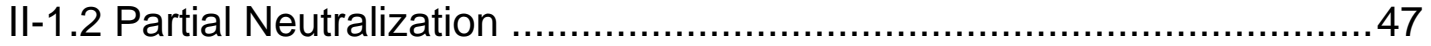

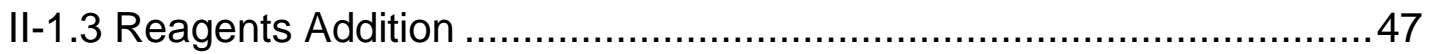

II-1.4 Partial Dewatering by Evaporation .............................................48

II-1.5 Ceramicrete Immobilization .................................................... 48

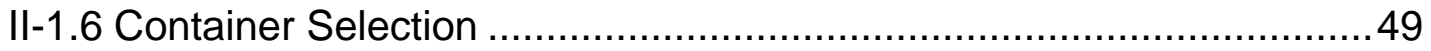


II-1.7 Container Interim Storage ..........................................................50

II-1.8 Deployment Concept and Integration with Other Hanford Facilities ...50

II-1.8.1 Deployment Concept............................................................50

II-1.8.2 Integration with Other Hanford Facilities ..................................53

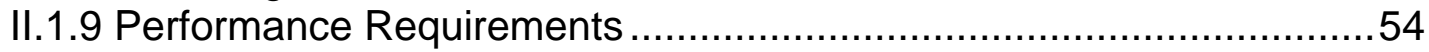

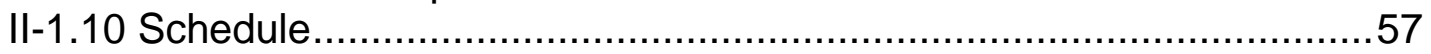

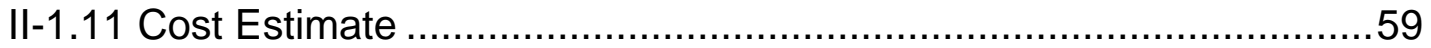

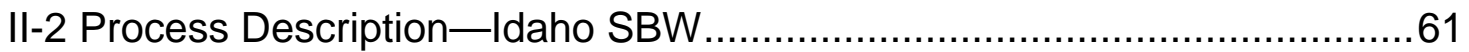

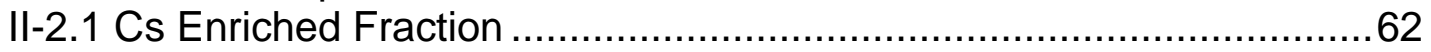

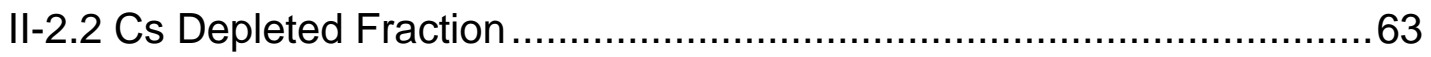

II-2.3 Deployment Concept and Integration with Other Idaho National

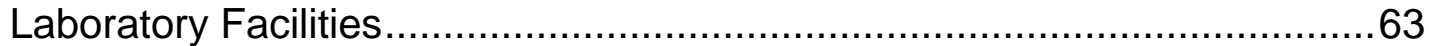

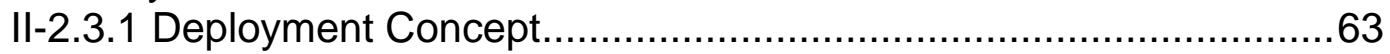

II-2.3.2 Integration with Other INL Facilities ..........................................64

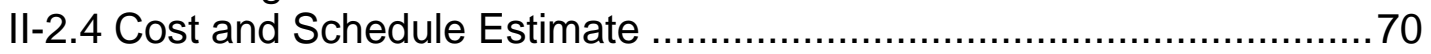

II-3 Uncertainties, Risks, and Potential Safety Issues ................................ 72

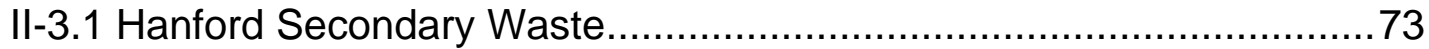

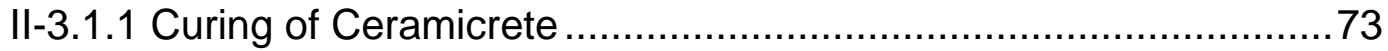

II-3.1.2 Evaporator Process Condensate …........................................ 73

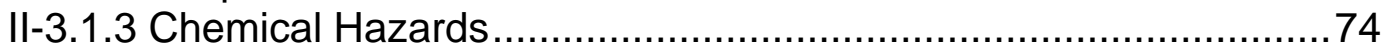

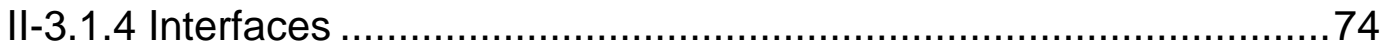

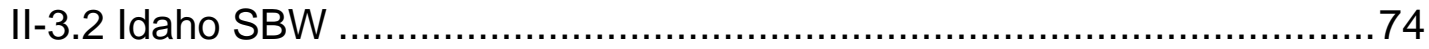

II-3.2.1 Uranium Exceeding Fissile Limits .......................................... 74

II-3.2.2 Equipment Malfunctions in the Remote-Handled Cell ..................74

II-3.2.3 Manual Drum Filling ........................................................... 74

II-3.2.4 Idaho Tank Waste Acceptance for WIPP Disposal ...................... 75

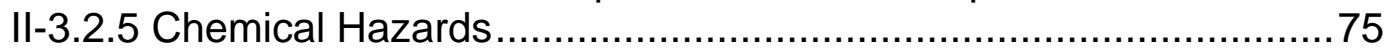

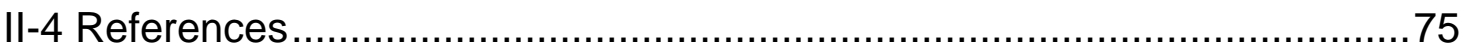

\section{List of Tables}

1 Basic Phosphate Ceramic Processes for Waste Applications [1] ..............2

2 Initial Observations on the Two Simulants …..................................... 3

3 Composition of HSW Simulant .................................................. 4

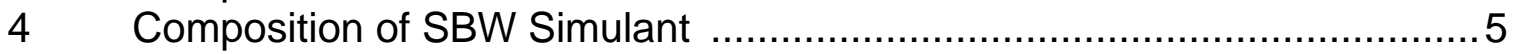

5 Compounds and Metal Levels Used for Spiking HSW and SBW

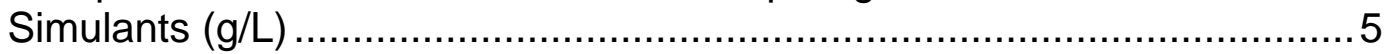

$6 \quad$ Composition of Simplified Waste Streams Used for Process Selection .....6

$7 \quad$ Neutralizing Reagents Used for SBW and HSW ................................. 8

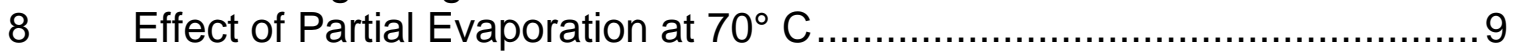

9 Constituents in SBW and HSW, and Their Stabilizing Reagents ............ 13

10 Make-up of the Test Waste Forms for Dewatered SBW and HSW (wt.\%)16

11 Batch Process Data for SBW and HSW Immobilization ........................ 17

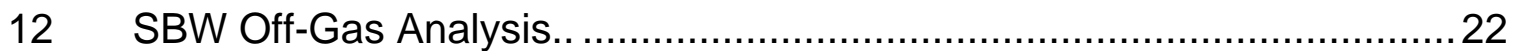

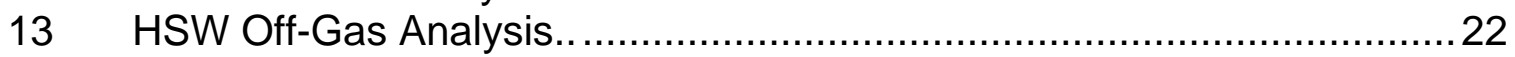

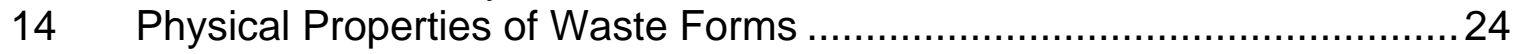




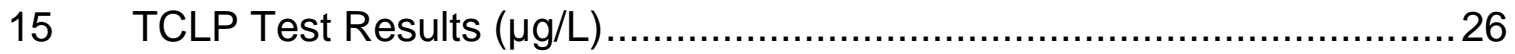

16 7-Day Leaching Indices (LI) for Radioactive Surrogates and Sodium for Spiked HSW Waste Forms..............................................................2

$17 \quad$ Normalized Leaching Rates (g/m2.day) per PCT .................................29

18 Summary of Waste Form Characteristics ............................................. 30

19 HSW Constituents as if Oxidized (based on one liter HSW) ................... 32

20 SBW Constituents as if Oxidized (based on one liter SBW) .....................33

21 Ceramicrete Immobilization of Hanford Secondary Waste-Summary Material Balance ....................................................................... 43

22 Disposal Container Evaluation ..................................................... 46

23 Preliminary Major Equipment List for Ceramicrete Immobilization Of HSW .................................................................................. 48

24 Preliminary Requirements Compliance Matrix for Hanford Secondary Waste Immobilization ........................................................................ 51

25 Hanford Low Temperature Waste Immobilization .................................56

26 Time and Cost Schedules for SBW Immobilization ...............................69

\section{List of Figures}

1 Temperature Profile During Fabrication of SBW and HSW Ceramics ......20

$2 \quad$ X-ray Identification of non-hazardous $\mathrm{Na}$ residue resulting from partial

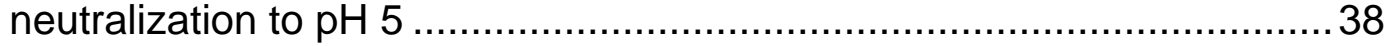

3 Conceptual Flow Diagram for Ceramicrete Immobilization of Hanford Secondary Waste ........................................................................ 42

4 Preliminary Facility Arrangement Diagram for Ceramicrete Immobilization of Hanford Secondary Waste ..............................................................49

$5 \quad$ Proposed Location of Ceramicrete Treatment Facility ..........................50

6 Preliminary Schedule-Hanford Secondary Waste Immobilization ...........54

7 Block Flow Diagram - CsPTA Separation and Ceramicrete Immobilization of Separate $\mathrm{RH}$ and $\mathrm{CH}$ Waste Fractions.............................................58

8 Room 214 Calciner Cell Cesium/Solids Separation/Immobilization Plan

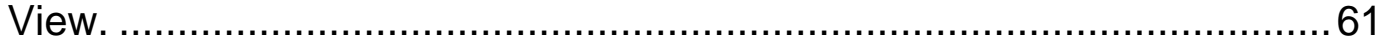

9 Room 214 Calciner Cell Cesium/Solids Separation/Immobilization Concept for RH Fraction.

10 Room 427 Supernate Immobilization Process Concept Using SWB Containers. 63

11 Room 427 Supernate Immobilization-Plan View Using Drums. 65 


\section{Preface}

Pacific Northwest National Laboratory (PNNL) contracted with CH2M HILL to perform a proof of concept for stabilization/solidification of waste streams that are simulants of: 1) sodium bearing waste (SBW); and 2) Hanford tank secondary waste (HSW) into a suitable, chemically bonded phosphate ceramic (CPBC) matrix. CH2M HILL entered into a Cooperative Research and Development Agreement (CRADA) with Argonne National Laboratory (ANL) for laboratory support as an extension of ongoing collaborative work on CPBCs between CH2M HILL and ANL. This report is a comprehensive summary of the work conducted for this project, and is arranged in two parts: the laboratory-scale demonstration work; and the concept for implementing full-scale ceramic immobilization facilities at Hanford and Idaho.

\section{Background}

Since the original 1978 American Physics Society (APS) Working Group on nuclear waste management, and continuing through 25 years of National Academy of Sciences (NAS) studies, ceramics have been identified as the high-performance technology of choice over glass and grout forms, because ceramic/mineral forms provide the greatest potential for long-term durability in the environment. In the most recent study on Hanford and Idaho wastes, "Research Needs of High-Level Waste" (2001), the NAS addressed not only durability but also the issues of load factor, feed stream variability, and the management of problematic waste constituents requiring separation and off-gas processing, both of which incur secondary waste treatment.

A potential solution to all of these problems was invented 10 years ago with the first of a family of phosphate-bonded ceramics that could be formed at ambient temperature. These phosphate ceramic systems are formed using acid-base reactions to convert radionuclide and hazardous metal constituents to chemically insoluble compounds, and to microencapsulate the compounds and any waste particulates in a $\mathrm{pH}$ neutral mineral matrix. Ionic and covalent bonding of the mineral phases and ceramic matrix provide a superior structural integrity. Unlike grout structures, the ceramic/mineral forms are essentially non-porous and unaffected by salts, solvents, and acids. Unlike vitreous forms, the ceramics can incorporate high concentrations of metals and salts that have limited solubility in glass, or that form phase boundaries in glass.

\section{Advantages in Risk and Cost}

The technology is simple, versatile, and safe, which adds up to low cost and low process technology risk. The waste form is highly durable and meets the specified acceptance criteria for this project, which add up to low environmental performance risk and an expedited acceptance, permitting, and implementation process.

- Simple. While the chemistry is completely different, the engineering and set-up is essentially the same as a grout plant; i.e., the process requires a hopper, pump, and mixer. Instead of typical cement and fly ash ingredients, a metal oxide and an acid phosphate are used. All of the equipment is off-the-shelf. Units can operate in either batch or continuous mode, and the waste/ceramic binder ingredients can either be processed in-container or mixed and pumped to a separate container line. Capital costs for grout facilities are far lower and known with greater certainty than costs for thermal processes. Operating costs and contingencies are also far lower.

- Versatile. The process tolerates a wide variability in waste characteristics. We have tested a wide range of surrogate and actual inorganic, organic, acidic transuranic (TRU) wastes, high-activity and low-activity tank wastes, oxides and halogenated Special Nuclear Material (SNM) from seven 
DOE sites, as well as high- and intermediate-level wastes in Russia. No constituents in the tank wastes have been found to require separation prior to ceramification. The same basic formulation applies across all waste characteristics, incorporating all constituents in the matrix with no byproducts or secondary wastes. In contrast, thermal processes typically require separation of problematic constituents.

- $\underline{\text { Safe. }}$. All unit operations are conducted under ambient temperature and pressure. (If dewatering to reduce waste volume is beneficial, a raised temperature of $70 \mathrm{C}$ is sufficient.) Process controls are simplified, and pre- and post-treatments, and secondary waste processing, are eliminated. In particular, potentially volatile constituents in the wastes are captured rather than released in the process. By contrast, thermal processes are characterized by complexity of design and operations and increased risk to workers from potential upsets. "Keep it simple" goes a long way toward "keep it safe."

- Durable. Tests to date on all ceramified DOE wastes have passed the criteria set forth in the Waste Isolation Pilot Plant (WIPP), High-Level Waste (HLW) Repository, and Hanford Integrated Disposal Facility (IDF) acceptance criteria; specifically, such key indicators of durability as the Product Consistency Test (PCT), American Nuclear Society (ANS) 16.1, and Toxicity Characteristics Leaching Procedure (TCLP)/Universal Treatment Standard (UTS), as well as strength and degradation under radioactive, heat, or immersion standards. The issue of long-term durability has driven research in nuclear countries for many years toward the development of mineral forms, as it is well known that minerals, such as phosphates, naturally resist degradation over geologic time. But such forms have always required high temperatures, which increases both the risk of occurrence and the consequences of incidents.

- Mature. Ambient temperature ceramic waste forms have been produced and tested extensively over 10 years, progressing from the laboratory to larger scale testing on a wide range of waste applications. CH2M HILL and ANL have collaborated continuously during this time to develop, improve, and adapt the original formulations for application to specific streams at DOE and Russian nuclear sites as a risk mitigation measure. In every case we have determined formulations that immobilize the waste to pass the prescribed leaching tests and physical-chemical (P-C) properties tests. A control study in one case between bench ( $\sim 1$ liter $)$ and intermediate ( $\sim 20$ liter $)$ scales showed that the chemical performance of the waste form does not change; i.e., as expected from first principles, the bulk properties at large scale are exhibited at bench scale. A mock up of a drum-scale operation similar to the lost paddle method in commercial use at nuclear sites in the UK was conducted using soil waste to establish the reliability of ceramic product homogeneity. In another control study, in Russia, we immobilized both surrogate and radioactive simulants of two different Hanford tank wastes, demonstrating in each of the two cases that the chemical performance was not changed by radioactive constituents. During the last 2 years, we also immobilized actual HLW and intermediate-level waste (ILW) tank wastes at bench scale at the Mayak production site, and conducted drum scale production tests on surrogates of these wastes.

Nuclear waste immobilization applications of the CBPC technology have proceeded slowly and deliberately from bench-scale to intermediate- and pilot-scale, and from surrogate to radioactive forms. On the other hand, civil and medical engineering and nuclear shielding applications have progressed much more quickly. Economic drivers have moved these ceramics through strict 
permitting processes, and are already in full commercial scale use. Because of its high strength and resistance to corrosion and natural degradation processes, Ceramicrete has been deployed commercially in 20 states for road, bridge, and housing construction using conventional grout equipment systems. The oil industry is performing demonstration tests for drilling casing and capping. The medical/dental industry is using several phosphate ceramic formulations for its material and binding properties. For nuclear shielding applications, Ceramicrete is doped with n-gamma Ceramicrete Bridge Deck, Chicago, Illinois

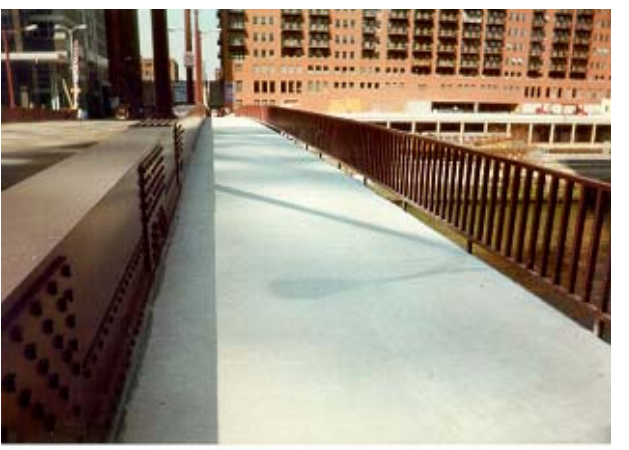
absorbants in the U.S. and Russia and is now being deployed for enriched uranium macroencapsulation and containerization in storage vaults at Oak Ridge. The chemistry of the material occurs at a molecular and particle size scale and is not affected by scale-up to these commercial deployment scales. Bulk thermal effects from the exothermic acid-base reactions have been managed at large scale.

After 10 years of testing on diverse waste and civil applications, scale-up of the CBPC process and use of commercial mixing equipment are not expected to present any significant technical risks. 


\section{Part I. Process Demonstration for HSW and SBW}

\section{I-1 Ceramic Process Fundamentals}

CBPCs are a class of materials that exhibit structure and properties similar to ceramics, and yet are synthesized like cements ${ }^{[1]}$. They are rapid-setting ceramics formed by acid-base reactions between a metal oxide and an acid phosphate. Some examples are magnesium phospho-silicate ceramic called Ceramicrete*; aluminum phosphate ceramic formed at $150^{\circ} \mathrm{C}$; iron phosphate ceramic formed at room temperature by reduction reaction; calcium and zinc phosphate cements used in dentistry; and doped Ceramicrete used in nuclear shielding. The first three were developed at ANL for stabilization of hazardous and radioactive waste streams with funding from the DOE Mixed Waste Focus Area ${ }^{[2]}$, as well as from Kaiser-Hill and $\mathrm{CH}_{2} \mathrm{M} \mathrm{HILL}^{[3]}$. These three ceramics have apatite, berlinite, and hematite mineral structures, respectively, that have proven to be very stable.

In each of these reactions, the alkaline metal oxide reacts with the acidic phosphate and forms a neutral matrix. As the equations indicate, the reactions require water in the same manner that cement needs water. It is possible to use liquid waste to provide this water and thus, the binder powders and the waste are mixed to form the ceramic.

Though the reactions imply stoichiometric water demand, practical experience has shown that it is possible to make Ceramicrete with at least 25 percent more water, and other CBPC ceramics can be made with much more than indicated in Table 1. The range of binder components can also be varied significantly. This versatility in the composition makes the process very suitable during scale-up and in practical applications.

\footnotetext{
* Ceramicrete is a trademark name owned by the DOE ANL
} 
Table 1-Basic Phosphate Ceramic Processes for Waste Applications ${ }^{[1]}$

\begin{tabular}{|c|c|c|}
\hline $\begin{array}{l}\text { Ceramic } \\
\text { Process }\end{array}$ & Chemical Reaction & Comments \\
\hline $\begin{array}{l}\text { Magnesium } \\
\text { potassium } \\
\text { phosphate }\end{array}$ & $\begin{array}{l}\mathrm{MgO}+\mathrm{KH}_{2} \mathrm{PO}_{4}+5 \mathrm{H}_{2} \mathrm{O}= \\
\mathrm{MgKPO}_{4} \cdot 6 \mathrm{H}_{2} \mathrm{O} \\
\text { Reaction occurs at room } \\
\text { temperature. }\end{array}$ & $\begin{array}{l}\text { With addition of amorphous silica, such as fly ash } \\
\text { or calcium silicate, a high-strength, dense matrix } \\
\text { called Ceramicrete is formed. Tested on a wide } \\
\text { range of simulants and actual radioactive waste } \\
\text { streams. }\end{array}$ \\
\hline $\begin{array}{l}\text { Aluminum } \\
\text { phosphate } \\
\text { (Berlinite) }\end{array}$ & $\begin{array}{l}\mathrm{Al}_{2} \mathrm{O}_{3}+2 \mathrm{H}_{3} \mathrm{PO}_{4}= \\
2 \mathrm{AlPO}_{4}+3 \mathrm{H}_{2} \mathrm{O} \\
\text { Reaction occurs at } 150^{\circ} \mathrm{C} .\end{array}$ & $\begin{array}{l}\text { Dense and very hard berlinite ceramics have been } \\
\text { developed for oil well cementing applications. } \\
\text { Initial tests indicate this may be a superior, } \\
\text { anhydrous waste form. Will be further tested as } \\
\text { funding is made available. }\end{array}$ \\
\hline $\begin{array}{l}\text { Iron } \\
\text { phosphate }\end{array}$ & $\begin{array}{l}\mathrm{Fe}_{2} \mathrm{O}_{3}+\mathrm{Fe}+3 \mathrm{H}_{3} \mathrm{PO}_{4} \\
+\mathrm{nH}_{2} \mathrm{O}=3 \mathrm{FeHPO}_{4} \\
\cdot(\mathrm{n}+3) \mathrm{H}_{2} \mathrm{O} \\
\text { Reaction occurs at room } \\
\text { temperature. }\end{array}$ & $\begin{array}{l}\text { Dense and hard product. A good candidate to } \\
\text { encapsulate radioactive waste in reduction } \\
\text { environment. Ideal for Tc-rich waste. The matrix is } \\
\text { glassy so actual phase is difficult to identify. The } \\
\text { equation represents only one possible simple } \\
\text { phase; other complex phases may be formed. In } \\
\text { practice, no water is released unless heat is } \\
\text { applied. }\end{array}$ \\
\hline
\end{tabular}

Typically, one adds the powder and the liquid waste in the stoichiometric proportions and mixes for 15 to 20 minutes. The mixture gets thick and hardens within 1 to 2 hours, depending on the waste characteristics. The setting can be controlled using a very small amount of boric acid (typically $<1$ percent) to allow more mixing or pumping time and also to control any exothermic heat generation. In this project, we did not use boric acid because the sodium-rich waste itself was a good moderator.

Though it is possible to mix the waste directly and add the binder powders to satisfy the above reactions, this will produce a large volume of the waste form. However, it is possible to dewater the waste without releasing contaminants, thereby getting rid of much of the water and reducing the volume of the waste package. A number of dewatering techniques can be used for this purpose. We have used moderate temperature $\left(\sim 50-70^{\circ} \mathrm{C}\right)$ evaporation in this project. 


\section{I-2 Waste Composition and Characteristics}

Two simulated waste streams, SBW and HSW, were sent by PNNL for stabilization in this project. Both came in 20-liter plastic containers. Table 2 provides some initial observations on the "as-received" waste streams.

Table 2-Initial Observations on the Two Simulants

\begin{tabular}{|l|l|l|l|l|l|}
\hline $\begin{array}{l}\text { Waste Stream } \\
\text { Identification }\end{array}$ & $\begin{array}{c}\text { Quantity } \\
\text { Received } \\
\text { (liters) }\end{array}$ & pH & \multicolumn{1}{|c|}{ Appearance } & $\begin{array}{l}\text { Density } \\
\text { (g/cm }\end{array}$ & \multicolumn{1}{|c|}{ Physical Form } \\
\hline SBW & 40 & 0.5 & Milky, grayish black & 1.2 & Liquid, slightly turbid \\
\hline HSW & 80 & 11.5 & White, cloudy & 1.08 & Liquid \\
\hline
\end{tabular}

SBW is highly acidic and HSW is alkaline; both are high in $\mathrm{Na}(2 \mathrm{M})$. We performed an analysis of both the waste streams and compared the compositions provided by Noah (PNNL's contractor for simulant preparation) with ours. The results are tabulated in Tables 3 and 4. For reference, these tables also list the target compositions intended to replicate the essential characteristics of these streams.

Table 3-Composition of HSW Simulant

\begin{tabular}{|c|c|c|c|c|}
\hline Element & $\begin{array}{c}\text { Target } \\
\text { (moles/L) }\end{array}$ & $\begin{array}{l}\text { Target } \\
\text { (g/L) }\end{array}$ & $\begin{array}{l}\text { Noah Data } \\
(g / L)\end{array}$ & $\begin{array}{l}\text { ANL Data } \\
(g / L)\end{array}$ \\
\hline B & & & & $3.6 \mathrm{E}-4$ \\
\hline $\mathrm{Na}$ & 2.0 & 46 & 45.17 & 48.9 \\
\hline $\mathrm{Al}$ & 0.011 & 0.299 & 0.318 & 0.123 \\
\hline $\mathrm{K}$ & & & & $1.04 \mathrm{E}-3$ \\
\hline $\mathrm{Cr}$ & $2.8 \mathrm{E}-4$ & 0.0145 & 0.0149 & $6.71 \mathrm{E}-4$ \\
\hline $\mathrm{Fe}$ & & & & $6.29 \mathrm{E}-4$ \\
\hline $\mathrm{Ag}$ & $2.2 \mathrm{E}-4$ & 0.0237 & 0.0235 & 0.0238 \\
\hline $\mathrm{Cd}$ & 1.4E-5 & 1.57E-3 & 1.57E-3 & $3.95 E-4$ \\
\hline Cs & & & & 1.7E-5 \\
\hline $\mathrm{Ce}$ & & & & $2.05 E-6$ \\
\hline $\operatorname{Re}(T c)$ & & & & $1.25 \mathrm{E}-4$ \\
\hline $\mathrm{Hg}$ & $2.4 \mathrm{E}-6$ & $4.81 \mathrm{E}-4$ & $4.15 \mathrm{E}-4$ & $9.9 \mathrm{E}-5$ \\
\hline $\mathrm{Pb}$ & $1.5 \mathrm{E}-4$ & 0.031 & 0.0323 & 0.024 \\
\hline $\mathrm{CO}_{3}^{-}$ & 0.96 & 57.6 & 60 & \\
\hline $\mathrm{NO}_{3}^{-}$ & 0.018 & 1.116 & 1.12 & 1.55 \\
\hline $\mathrm{OH}^{-}$ & 0.094 & 1.598 & 1.6 & \\
\hline TOC & 0.18 & 13.86 & 13.86 & \\
\hline
\end{tabular}

Where no data are given, the analysis was not reported. 
Table 4-Composition of SBW Simulant

\begin{tabular}{|c|c|c|c|c|}
\hline Element & $\begin{array}{c}\text { Target } \\
\text { (moles/L) }\end{array}$ & $\begin{array}{l}\text { Target } \\
\text { (g/L) }\end{array}$ & $\begin{array}{l}\text { Noah Data } \\
(\mathrm{g} / \mathrm{L})\end{array}$ & $\begin{array}{l}\text { ANL Data } \\
\text { (g/L) }\end{array}$ \\
\hline $\mathrm{Na}$ & 1.88 & 43.24 & 43.2 & 50.5 \\
\hline $\mathrm{Al}$ & 0.575 & 15.5 & 17.8 & 18.7 \\
\hline $\mathrm{Ca}$ & 0.0366 & 1.464 & 1.46 & 1.7 \\
\hline$B$ & 0.0102 & 0.11 & 0.11 & 0.12 \\
\hline $\mathrm{Mg}$ & 0.0108 & 0.26 & 0.26 & 0.37 \\
\hline $\mathrm{K}$ & 0.175 & 6.825 & 6.8 & 7.1 \\
\hline $\mathrm{Cr}$ & 0.0033 & 0.172 & 0.172 & 0.165 \\
\hline $\mathrm{Mn}$ & 0.0126 & 0.69 & 0.69 & 0.65 \\
\hline $\mathrm{Fe}$ & 0.0178 & 0.993 & 0.99 & 1.01 \\
\hline $\mathrm{Ag}$ & & & & $4.3 \mathrm{E}-5$ \\
\hline $\mathrm{Cd}$ & 0.0007 & 0.0786 & 0.078 & 0.075 \\
\hline Cs & & & & $2.34 \mathrm{E}-5$ \\
\hline $\mathrm{Ce}$ & & & & $7.82 \mathrm{E}-4$ \\
\hline $\mathrm{Hg}$ & 0.0020 & 0.401 & 0.4 & 0.33 \\
\hline $\mathrm{Pb}$ & 0.0013 & 0.269 & 0.27 & 0.27 \\
\hline $\operatorname{Re}(\mathrm{Tc})$ & & & & 6.37E-4 \\
\hline I & & & & $3.43 E-3$ \\
\hline $\mathrm{SO}_{4}^{-}$ & 0.0491 & 4.71 & & 5.15 \\
\hline $\mathrm{H}_{2} \mathrm{O}$ & & & 812 & \\
\hline $\mathrm{NO}_{3}^{-}$ & 4.91 & 304.4 & & 269 \\
\hline$F$ & 0.0403 & 0.765 & & 0.83 \\
\hline $\mathrm{Cl}$ & 0.0285 & 1.009 & & 1.15 \\
\hline $\mathrm{H}$ & 2.0 & 2.0 & & \\
\hline
\end{tabular}

ANL's data were measured by inductively coupled plasma-mass spectrometry (ICP-MS), which is very accurate for the heavy elements (atomic number greater than iron). For the lighter elements, the accuracy may not be good, especially when their concentration is small.

There are only small differences between the composition in the RFP, the composition sent by Noah with the prepared simulants, and the composition provided by ANL. We note that in HSW, ANL did not find iodine and also did not find much $\mathrm{Cr}$. Cr is a hazardous contaminant and PNNL Performance Assessment work indicates I is the constituent of most interest in HSW. After consultation with PNNL, 
we spiked both simulants with surrogates of radioactive contaminants for purposes of conducting leach tests.

Table 5 gives the oxides and salts used for spiking both simulants at the same levels. All metals added were in the range of $100 \mathrm{mg} / \mathrm{L}$ in the waste. The compounds were introduced as very fine powders.

Table 5-Compounds and Metal Levels Used for Spiking HSW and SBW Simulants (g/L)

\begin{tabular}{|l|l|l|l|}
\hline \multicolumn{1}{|c|}{ Compound } & \multicolumn{1}{|c|}{$\begin{array}{c}\text { Surrogate } \\
\text { Representing }\end{array}$} & \multicolumn{1}{|c|}{$\begin{array}{c}\text { Amount } \\
\text { Added }\end{array}$} & $\begin{array}{c}\text { Surrogate Metal Level in } \\
\text { HSW and SBW }\end{array}$ \\
\hline $\mathrm{Nal}$ & Soluble iodine compounds & 0.12 & 0.102 \\
\hline $\mathrm{Re}_{2} \mathrm{O}_{7}$ & $\mathrm{TC}_{2} \mathrm{O}_{7}$ & 0.12 & 0.092 \\
\hline $\mathrm{CsCl}$ & Soluble cesium compounds & 0.12 & 0.095 \\
\hline $\mathrm{CeO}_{2}$ & $\mathrm{UO}_{2}, \mathrm{PuO}_{2}$ & 0.12 & 0.098 \\
\hline
\end{tabular}

\section{I-3 Process Trials and Selection}

The initial process development was conducted mainly for SBW, which also gave good indications of the most suitable process for HSW. Rather than using part of the waste streams provided by PNNL, we prepared simplified compositions without hazardous metals and radioactive surrogates, since these have no significant impact on the general process. The simplified compositions used for these preliminary tests are given in Table 6.

Table 6-Composition of the Simplified Waste Streams Used for Process Selection 6.A Target and Actual Ionic Concentrations and Compounds Used

\begin{tabular}{|c|c|c|c|c|c|c|}
\hline \multirow[t]{2}{*}{ Ion } & \multicolumn{2}{|c|}{$\begin{array}{l}\text { Minimum Target } \\
\text { provided by PNNL } \\
\text { (moles/L) }\end{array}$} & \multicolumn{2}{|c|}{$\begin{array}{l}\text { Actual Amount Added } \\
\text { (moles/L) }\end{array}$} & \multicolumn{2}{|c|}{ Added as: } \\
\hline & SBW & HSW & SBW & HSW & SBW & HSW \\
\hline $\mathrm{Na}^{+}$ & 1.88 & 2 & 2.42 & 2.39 & $\begin{array}{l}\mathrm{NaNO}_{3} \\
\mathrm{Na}_{2} \mathrm{SO}_{4} \\
\mathrm{NaF}\end{array}$ & $\begin{array}{l}\mathrm{NaNO}_{3} \\
\mathrm{Na}_{2} \mathrm{CO}_{3}\end{array}$ \\
\hline $\mathrm{NO}_{3}^{-}$ & 4.91 & 0.018 & 5.73 & 0.051 & $\begin{array}{l}\mathrm{NaNO}_{3} \\
\mathrm{HNO}_{3} \\
\mathrm{KNO}_{3}\end{array}$ & $\mathrm{NaNO}_{3}$ \\
\hline $\mathrm{CO}_{3}^{2-}$ & & 0.96 & & 1.2 & & $\mathrm{Na}_{2} \mathrm{CO}_{3}$ \\
\hline $\mathrm{Al}^{3+}$ & 0.575 & 0.011 & 0.71 & 0.012 & $\mathrm{Al}_{2} \mathrm{O}_{3}$ & $\mathrm{Al}(\mathrm{OH})_{3}$ \\
\hline $\mathrm{SO}_{4}{ }^{2-}$ & 0.0491 & & 0.042 & & $\mathrm{Na}_{2} \mathrm{SO}_{4}$ & \\
\hline $\mathrm{NH}_{3}{ }^{+}$ & & & & 2.6 & & $\begin{array}{l}\mathrm{NH}_{4} \mathrm{OH} \\
(30 \text { wt. } \\
\end{array}$ \\
\hline
\end{tabular}


6.B Composition in Wt. percentage

\begin{tabular}{|l|l|l|}
\hline \multicolumn{1}{|c|}{ Component } & \multicolumn{1}{c|}{ In SBW } & \multicolumn{1}{c|}{ In HSW } \\
\hline $\mathrm{H}_{2} \mathrm{O}$ & 64.6 & 69.6 \\
\hline $\mathrm{HNO}_{3}$ & 13.9 & \\
\hline $\mathrm{NaNO}_{3}$ & 12.7 & 0.29 \\
\hline $\mathrm{KNO}_{3}$ & 1.5 & \\
\hline $\mathrm{Na}_{2} \mathrm{SO}_{4}$ & 0.3 & \\
\hline $\mathrm{NaF}$ & 0.07 & \\
\hline $\mathrm{Al}_{2} \mathrm{O}_{3}$ & 8.1 & \\
\hline $\mathrm{Al}(\mathrm{OH})_{3}$ & & 0.06 \\
\hline $\mathrm{Na}_{2} \mathrm{CO}_{3}$ & & 8.8 \\
\hline $\mathrm{NH}_{4} \mathrm{OH}(30 \%)$ strength & & 21.1 \\
\hline
\end{tabular}

SBW contains a large amount of nitrates, some in the form of nitric acid. In addition, sodium and alumina contents are also significant. HSW contains mainly water with sodium carbonate, ammonia, and organic compounds such as hydroxyacetate. Both waste streams are high in sodium and contain hazardous contaminants as well as fission products.

In order to select a suitable phosphate ceramic process, we proceeded along the following steps.

\section{I-3.1 Neutralization of the Waste Streams}

SBW is acidic with a $\mathrm{pH}=0.5 ; \mathrm{HSW}$ is alkaline with a $\mathrm{pH}=12$. It is necessary to partially neutralize both the waste streams prior to using the CBPC process because the process is based on acid-base reactions and the object is to produce neutral ceramics. A neutral waste form is preferred for its geologic stability. An acidic or basic waste material will imbalance the reactions and may produce poor, non-neutral cements. Not accounting for such waste characteristics in the process selection is a common mistake made by researchers unfamiliar with the chemistry of the CPBC process, and often results in a phosphate cement, rather than in a ceramic mineral waste form.

We tested $\mathrm{MgO}$ and $\mathrm{NaOH}$ options for neutralization of SBW, and observed that more $\mathrm{MgO}$, due to lower solubility than $\mathrm{NaOH}$, had to be added to neutralize the same amount of waste. Thus, for load factor considerations, $\mathrm{NaOH}$ is the more 
efficient reagent, even though $\mathrm{MgO}$ is a part of the Ceramicrete composition and performs equally well. For neutralizing HSW, phosphoric acid was preferred over other acids such as nitric and hydrochloric acids, because phosphates are a part of the Ceramicrete process, and during neutralization they help in stabilizing many waste constituents by converting them into insoluble phosphate forms.

Table 7 summarizes the reagents used to partially neutralize the two waste streams to $\mathrm{a} \mathrm{pH} \sim 5$. The addition of reagent increases the volume of the final product by a few percent points.

Table 7-Neutralizing Reagents Used for SBW and HSW

\begin{tabular}{|l|l|l|l|}
\hline \multicolumn{1}{|c|}{ Waste } & \multicolumn{1}{|c|}{ Agent } & Amount added (g/L) & \multicolumn{1}{c|}{ Final pH } \\
\hline SBW & $\mathrm{NaOH}$ & 35 & 5 \\
\hline $\mathrm{HSW}$ & $\mathrm{H}_{3} \mathrm{PO}_{4}$ & 140 & 5 \\
\hline
\end{tabular}

In hindsight, a small amount of $\mathrm{Na}$ in the two stimulant streams was not immobilized in the waste form. After immersion for a few weeks, PNNL observed a white compound on the specimen surface and in the leachate. Using $x$-ray diffraction (XRD), we identified this compound as $\mathrm{Na}_{2} \mathrm{HPO}_{4}$, a non-hazardous substance. To avoid this in the future, both streams should be adjusted to a $\mathrm{pH}=4$ or less (since $\mathrm{NaH}_{2} \mathrm{PO}_{4}$ reacts to form ceramic but $\mathrm{Na}_{2} \mathrm{HPO}_{4}$ does not). Also, $\mathrm{HSW}$ should be neutralized using $\mathrm{MgO}$ rather than $\mathrm{NaOH}$. These changes are recommended for wastes with high $\mathrm{Na}$ content.

\section{1-3.2 Waste Stream Dewatering}

Both waste streams are dilute aqueous liquids. Although Ceramicrete can incorporate the large amount of water, we evaporated some of it, thus reducing the volume of the final waste form significantly. The moisture content of actual HSW will depend on how it is processed and delivered for final immobilization and disposal. That process is uncertain at this point; one such process would deliver HSW as a filter cake rather than a dilute liquid.

Trial evaporation of the waste streams was carried out to determine how much volume reduction could be readily achieved without introducing any process issues that might delay this demonstration project. Table 8 provides observations on both 
waste streams after 4 hours of evaporation in the $60-70^{\circ} \mathrm{C}$ range. Other temperature and time combinations were not studied. The simplified wastes used for process selection did not contain hazardous constituents.

Table 8-Effect of Partial Evaporation at $70^{\circ} \mathrm{C}$ and at 1 atmosphere

\begin{tabular}{|l|l|l|}
\hline $\begin{array}{c}\text { Waste } \\
\text { Stream }\end{array}$ & \multicolumn{1}{|c|}{$\begin{array}{c}\text { Volume Reduction } \\
\text { (\%) }\end{array}$} & \multicolumn{1}{c|}{$\begin{array}{c}\text { Physical State of the } \\
\text { Waste Stream }\end{array}$} \\
\hline SBW & 37 & Gel type consistency \\
\hline HSW & 58 & Liquid with suspended solids; opaque, gray brown \\
\hline
\end{tabular}

It is suspected that the gel-type of consistency formed in SBW may be due to its alumina content, which in presence of water forms hydrargilite $\left(\mathrm{Al}_{2} \mathrm{O}_{3} \cdot 3 \mathrm{H}_{2} \mathrm{O}\right)$, a geltype material. On the other hand, since HSW did not have such material, it remained liquid after its reduction to 42 percent of original volume. Because some amount of water is needed to form phosphate ceramics, we stopped evaporating at this point and began sample preparation and testing. The density of the dewatered SBW slurry was 1.4. Since immobilization of this slurry was easily achieved, we then evaporated HSW to the same density. Further work is needed to optimize the evaporation end points for HSW and SBW before an eventual deployment decision is made.

The extent of evaporation is an economic issue. More evaporation (especially as the waste thickens) may or may not be cost effective. It will yield a lower waste form volume, but some water is needed to initiate the reactions and thorough mixing of the concentrated waste with the ceramic binder material is essential. Fortunately, the CBPC processes allow at least 25 percent more water in the reaction than indicated by the stoichiometric proportion. Thus, these ceramic processes are versatile and do not require a specific amount of water for successful reaction of a particular waste.

\section{I-3.3 Nitrate Reduction}

SBW contains a very significant amount of $\mathrm{NO}_{3}$. It may be possible to reduce $\mathrm{NO}_{3}$ and form $\mathrm{NO}_{2}$, or $\mathrm{NO}$ and allow it to leave the waste. In this way some waste will have decomposed, reducing the volume.

We made several attempts to reduce $\mathrm{NO}_{3}$ to $\mathrm{NO}_{2}$ and ammonium ion, including use of iron as reductant in the Ceramicrete process and also as an agent to produce 
the iron phosphate ceramic matrix. There was no indication that this reduction occurred in our trials; therefore, this idea was not pursued.

\section{1-3.4 Ammonium Waste Form}

Alternatively, it may also be possible to convert $\mathrm{NO}_{3}$ to $\mathrm{NH}_{4}$ ion and thereby produce ammonium mono or dihydrogen phosphate, from which magnesium ammonium phosphate ceramic is produced. In principle, conversion of waste constituents offers the potential for a reduced volume of the final waste form.

This idea was attractive because Sugama et $\mathrm{al}^{[4]}$ have produced magnesium ammonium phosphate ceramics at room temperature and their process could be directly applicable to this project. Unfortunately, we did not find any direct evidence of ammonium ion formation during the reduction of the waste. It would take additional work to determine whether it is feasible to convert $\mathrm{NO}_{3}$ to ammonium ion within the room temperature ceramic process.

\section{1-3.5 Incorporation of Sodium in Ceramic Mineral Binder}

It may be possible to use $\mathrm{Na}$ from the waste to form $\mathrm{MgNaPO}_{4}$, a ceramic that would also act as a binder. Again, we will have reduced the quantity of waste form to be disposed.

In this trial, we did get a ceramic. However, we found that $\mathrm{MgNaPO}_{4}$ was a glassy binder with a comparatively fragile structure. It developed cracks when immersed in water. For this reason, this idea was also abandoned. $\mathrm{MgNaPO}_{4}$ better exists within a more crystalline matrix, such as $\mathrm{MgKPO}_{4}$, than in forming the matrix itself.

\section{I-3.6 Berlinite Waste Form}

Since the waste will be heated to reduce its volume, it is also possible with additional heat (up to $150^{\circ} \mathrm{C}$ ) to produce aluminum phosphate as a binder that can be used as an alternative waste form.

We solidified both HSW and SBW using this process, and SBW seemed particularly advantageous because of its Al content. We successfully used the alumina already present in SBW, and with moderate heat, produced an aluminum phosphate (berlinite) ceramic matrix. This mineral form looks to be very promising 
for some waste streams-not only for wastes high in Al, but also for wastes whose disposition imposes special constraints. Specifically, if waste form volume is a critical issue, our berlinite process eliminates all water; if radiolytic gas generation is a critical issue, the berlinite waste form is anhydrous. Generally, however, the volume factor is one of economic trade-off, and radiolytic gas generation in Ceramicrete is very low, meeting acceptance criteria in most case ${ }^{[5]}$. This derives from the inherent low porosity, low diffusivity, and hydrogen getter characteristics of Ceramicrete. For this project with HSW and SBW, the berlinite matrix contained many compounds that we have not yet identified and studied sufficiently to understand their chemistry and microstructure. Until we learn more, we cannot recommend the berlinite form for SBW. We consider this option to be at the development, rather than the demonstration stage. With additional funding for analytical testing, a more economical process than Ceramicrete may be identified for waste streams, such as SBW, that have significant amounts of alumina.

With conventional Ceramicrete, many aluminum compounds in many types of wastes have been successfully stabilized in the ceramic matrix. That is the case for this project as well; however, it may not be the optimized load factor solution for now.

\section{1-3.7 Process Selection for this Project}

Based on the above technical trials, and considering our project limits, we used the Ceramicrete process for the subsequent studies on both HSW and SBW. A key consideration was that the compounds formed between the Ceramicrete mix and these two wastes were well understood, based on prior studies and the trials for this project. In addition to $\mathrm{MgO}$ and $\mathrm{KH}_{2} \mathrm{PO}_{4}$ powders, calcium silicate $\left(\mathrm{CaSiO}_{3}\right)$ was used to form phosphor silicates which exhibit pore-free and high-strength ceramics $^{[6]}$. It is also possible, and probably preferable, to use Class $\mathrm{F}$ or Class $\mathrm{C}$ fly ash in place of the commercial silicate. We selected calcium silicate because it is a standard mineral readily available from laboratory supply.

For large-scale deployment, we anticipate that fly ash will be used for economy and to produce a waste form closer to $\mathrm{a} \mathrm{pH}=7$ than is possible with the addition of calcium. A concurrent study funded by DOE on development of phosphate cements 
for Yucca Mountain has shown that the use of fly ash in Ceramicrete provides a near neutral matrix (report yet to be released, 2006). A neutral form is wanted for longterm durability and to avoid potential actinide leaching that occurs in a high $\mathrm{pH}$ (cement) environment.

\section{I-3.8 Addition of Reagents to Stabilize Problem Metals}

The literature on Ceramicrete has provided ample evidence of converting certain hazardous as well as radioactive constituents to insoluble forms using very small amounts of reagents ${ }^{[7,8]}$. Additives are used in the Resource Conservation and Recovery Act (RCRA) waste stabilization industry at treatment facilities worldwide to render certain compounds insoluble within conventional grout matrices. With the CBPC process, many but not all constituents are automatically converted to insoluble phosphates. The purpose of adding reagents to the Ceramicrete mix is to convert certain constituents to insoluble compounds, which are then microencapsulated in the ceramic matrix. Table 9 lists the reagents that have been very effective on HSW and SBW constituents.

Due to our past experience with most of the constituents, stabilization was not a significant issue except for iodine, which we attempted to stabilize for the first time. Trials were run with oxides of bismuth and silver and with silver zeolite (Ag-Z), the latter proving the most effective at retaining both iodine and silver. $\mathrm{Ag}$-zeolite $\left(\mathrm{Ag}_{2} \mathrm{O}\right.$ $\mathrm{Al}_{2} \mathrm{O}_{3}-\mathrm{SiO}_{2}$ ) has been an excellent stabilizer of contaminants in general and for iodine in particular ${ }^{[9,10]}$. Also, Clark and Westberg ${ }^{[11]}$ have shown that it is a very effective stabilizer of iodine in cement grout materials.

Table 9-Constituents in SBW and HSW, and Their Stabilizing Reagents

\begin{tabular}{|c|c|c|}
\hline Constituent & Reagent & Comments \\
\hline As & None & \multirow{5}{*}{$\begin{array}{l}\text { Earlier studies have shown that the CBPC process converts } \\
\text { these constituents into their phosphate forms which are } \\
\text { insoluble/non-leachable }{ }^{[7]} \text {. }\end{array}$} \\
\hline $\mathrm{Ag}$ & None & \\
\hline $\mathrm{Pb}$ & None & \\
\hline $\mathrm{Ni}$ & None & \\
\hline $\mathrm{Cd}$ & None & \\
\hline $\mathrm{Hg}$ & $\mathrm{Na}_{2} \mathrm{~S}$ & \multirow{2}{*}{$\begin{array}{l}\text { These constituents are converted to their most insoluble } \\
\text { sulfides, such as } \mathrm{HgS} \text { and } \mathrm{CrS} \text {, as well as } \mathrm{CrPO}_{4}^{[7,8]} \text {. }\end{array}$} \\
\hline $\mathrm{Cr}$ & $\mathrm{Na}_{2} \mathrm{~S}$ & \\
\hline
\end{tabular}




\begin{tabular}{|c|c|c|}
\hline Constituent & Reagent & Comments \\
\hline $\mathrm{U}, \mathrm{Pu}$ & None & $\begin{array}{l}\text { Fully oxidized TRUs are insoluble; those in lower oxidation } \\
\text { states form insoluble phosphates }{ }^{[5]} \text {. }\end{array}$ \\
\hline Cs & None & $\begin{array}{l}\text { Cs is converted to insoluble phosphates }{ }^{[1]} \text { and also to a } \\
\text { phosphate mineral as part of the binder. }\end{array}$ \\
\hline Tc (Re) & $\mathrm{SnCl}_{2}$ & $\begin{array}{l}\text { Tc (also } \mathrm{Re}) \text { is reduced from }+7 \text { to }+4 \text { state as insoluble } \\
\mathrm{TcO}_{2}{ }^{[8]} \text {. }\end{array}$ \\
\hline I & $\begin{array}{l}\text { Ag-zeolite } \\
\left(\mathrm{AgO}-\mathrm{Al}_{2} \mathrm{O}_{3}-\right. \\
\left.\mathrm{SiO}_{2}\right) \text { with } \\
>40 \% \text { silver }\end{array}$ & $\begin{array}{l}\text { Ag-zeolite has been investigated in phosphate ceramics for the } \\
\text { first time in this project. It has been previously shown to work } \\
\text { in Cast Stone }{ }^{[11]} \text {. Ag is a common stabilizer in the RCRA waste } \\
\text { industry. Other silver compounds can also be used, but we } \\
\text { observed zeolite to be very effective. }\end{array}$ \\
\hline
\end{tabular}

For HSW and SBW, sodium sulfide, tin chloride, and Ag-zeolite were the three additives we used as stabilizing reagents. The rest of the contaminants were stabilized by the phosphate matrix itself. We did not attempt to optimize the amounts of additives according to the constituent concentrations in the wastes. To keep the overall process as simple as possible, we used the same amount of active elemental additive for all three reagents and for both wastes. This derived from a convenient, albeit arbitrary, selection of $1 \mathrm{~g}$ additive in each 150-ml batch we used for our process selection trials (i.e., $6.6 \mathrm{~g} / \mathrm{L}$ for $\mathrm{Na}_{2} \mathrm{~S}$ and $\mathrm{SnCl}_{2}$ and $16,5 \mathrm{~g} / \mathrm{L}$ for $\mathrm{Ag}-\mathrm{Z}$, of which $\sim 6.6 \mathrm{~g} / \mathrm{L}$ is $\mathrm{Ag}$ ).

\section{1-3.9 Load Factor Trials}

Trials were conducted using the simplified stream composition and the Ceramicrete process to increase the waste loadings of both SBW and HSW without compromising the waste form integrity. We arrived at waste loadings of 50 percent for SBW and 38 percent for HSW, based on the ratio of waste to waste form by weight (wet basis). We expect these can be increased with additional trials, but our performance tests and the samples sent to PNNL for testing were prepared on this basis.

The higher waste loading in SBW (less binder added) can be explained by the higher solids content and alumina in SBW. Alumina, as aluminum hydroxide, forms aluminum hydrophosphate gel (hydrargillite) in the presence of phosphates. The gel traps water and retards its release through evaporation. This results in a higher 
solids content, water trapped in aluminum hydroxide, less free water for reaction with the Ceramicrete binder mix, and hence, less binder needed. The water in excess of the stoichiometric limit is microencapsulated in the ceramic mostly as aluminum hydrophosphate.

The HSW waste loading is limited mainly by the stoichiometric requirement for sufficient water to react with the binder mix. We did not get to that limit in this project.

In a follow-up study, we will evaporate both HSW and SBW further to determine the limits and optimize the waste form load factor and volume. Besides the availability of water in the waste to drive the reactions, another limit for these two wastes may be the final concentration of sodium after evaporation. If so, additional water and binder may be required to enhance the wanted reactions, hardening of the waste form, and incorporation of as much sodium as practical in its ceramic form. This is hypothetical, based on solution chemistry; we have not yet investigated whether or not sodium would be a limiting factor. Also, as discussed in Section I-3.6 above (regarding berlinite), a follow-up study is needed to confirm that the berlinite waste form would meet all the performance requirements at an even lower volume than an optimized Ceramicrete waste form.

\section{I-4 Sample Preparation}

\section{I-4.1 Method Used to Prepare Samples}

Based on the above trials to select a suitable ceramic process for HSW and SBW, a sequence of steps was indicated for sample preparation that is likely to prove successful. The sequence is essentially neutralization-reagent additionevaporation-ceramification. The first three steps are not needed for many wastes, but are helpful for SBW and HSW due to their pH characteristics; soluble $\mathrm{Cr}, \mathrm{Hg}, \mathrm{Tc}$, and I states; and, high-water content. The process is very simple and can be described as follows:

- Neutralization. HSW and SBW simulants are partially neutralized to a $\mathrm{pH}=5$ using $\mathrm{H}_{3} \mathrm{PO}_{4}$ and $\mathrm{NaOH}$, respectively. Temperature rises to $\sim 50^{\circ} \mathrm{C}$ and is allowed to cool to $\sim 25^{\circ}-30^{\circ} \mathrm{C}$. Temperature is controlled by the rate of 
neutralization, and can easily be kept well below the boiling point (note: we would have obtained improved results had we neutralized to a $\mathrm{pH}=4$ and used $\mathrm{MgO}$ instead of $\mathrm{NaOH}$ for these high Na streams. cf. Section I-3.1).

- Reagent Addition. Small amounts of $\mathrm{Na}_{2} \mathrm{~S}, \mathrm{SnCl}_{2}$, and $\mathrm{Ag}-\mathrm{Z}$ are added to precipitate insoluble compounds of $\mathrm{Hg}$ and $\mathrm{Cr}$, $\mathrm{Tc}(\mathrm{Re})$, and I, respectively, in preparation for subsequent microencapsulation in the ceramic matrix. Temperature and $\mathrm{pH}$ remain unchanged.

- Evaporation. Some water in HSW and SBW is evaporated at $\sim 65^{\circ} \mathrm{C}$ for 4 hours to reduce volume. Off-gas collection is set up as needed to monitor potentially regulated emissions. Concentrated slurry is allowed to cool to $\sim 25^{\circ}-30^{\circ} \mathrm{C} ; \mathrm{pH}$ increases to $\sim 6$.

- Ceramification. Ceramicrete binder mix $\left(\mathrm{MgO}, \mathrm{KH}_{2} \mathrm{PO}_{4}, \mathrm{CaSiO}_{3}\right)$ is added and stirred $\sim 20$ minutes (+/-) to effect reactions that convert waste constituents to insoluble compounds and ceramics, produce a ceramic matrix, and microencapsulate constituents. Temperature rises to $\sim 35^{\circ} \mathrm{C}$ then cools; $\mathrm{pH}$ increases to $\sim 7-8$. Slurry is poured into testing forms and cured for 7 to 21 days.

A sparsely soluble silica source, such as fly ash or wollastonite $\left(\mathrm{CaSiO}_{3}\right)$, improves the properties of the Ceramicrete matrix ${ }^{[12]}$, but increases the volume. We did not perform tests to determine the optimal silica content for SBW and HSW in this project. We chose wollastonite because this mineral is standardized by the suppliers, while fly ash varies from source to source. For deployment, however, we expect the use of Class $\mathrm{C}$ ash will be better as it would produce ceramics at $\mathrm{pH}$ levels closer to neutral. A waste form lower in calcium content will be more durable on a geologic time scale. Just as with conventional cements, calcium becomes calcium carbonate and leads to waste form deterioration. In previous studies on Hanford wastes ${ }^{[3]}$, we used fly ash for supernate simulants and no silica additive for sludge simulants.

With this process, both SBW and HSW simulants provided by PNNL were solidified and several samples were made. Small differences were observed in the 
amount of stabilizer additives for the two wastes and in the evaporation temperatures and times for each batch, but the general procedure followed was the same. That is, the process does not require exacting quantities and controls. Table 10 provides the makeup of the test samples.

Table 10-Makeup of Test Waste Forms for Dewatered SBW and HSW (wt.\%)

\begin{tabular}{|c|c|c|c|c|c|c|c|}
\hline $\begin{array}{l}\text { Waste } \\
\text { Stream }\end{array}$ & $\begin{array}{c}\text { Neutralizer } \\
\text { Additive }\end{array}$ & $\begin{array}{l}\text { Stabilizer } \\
\text { Additives }\end{array}$ & $\begin{array}{l}\text { Stabilized } \\
\text { Element }\end{array}$ & MgO & $\mathrm{KH}_{2} \mathrm{PO}_{4}$ & $\mathrm{CaSiO}_{3}$ & $\begin{array}{l}\text { Dewatered } \\
\text { Waste } \\
\text { Loading } \\
\text { (wet basis) }\end{array}$ \\
\hline SBW & $\mathrm{NaOH}=2.2$ & $\begin{array}{l}\mathrm{Ag}-\mathrm{Z}=1.06 \\
\mathrm{Na}_{2} \mathrm{~S}=0.42 \\
\mathrm{SnCl}_{2}=0.42\end{array}$ & $\begin{array}{l}\mathrm{I} \\
\mathrm{Hg} \\
\mathrm{Re}\end{array}$ & 9.3 & 27.8 & 11.4 & 47.4 \\
\hline HSW & $\begin{array}{l}\mathrm{H}_{3} \mathrm{PO}_{4}= \\
10.1\end{array}$ & $\begin{array}{l}\mathrm{Ag}-\mathrm{Z}=1.2 \\
\mathrm{SnCl}_{2}=0.47\end{array}$ & $\begin{array}{l}\mathrm{I} \\
\mathrm{Re}\end{array}$ & 12.0 & 35.9 & 14.4 & 25.8 \\
\hline
\end{tabular}

We produced a large number of cylindrical samples for testing. These were made from waste simulants that were "as received," and also from simulants that we spiked with comparatively high levels ( $100 \mathrm{mg} / \mathrm{L})$ of surrogates for I, Cs, Tc, and actinides (cf. Table 5).

The waste loading in HSW samples was comparatively lower than that in the SBW samples, as discussed earlier. This is due to the greater amount of water in the HSW (following evaporation) available for reactions between waste constituents and binder mix. In future work, we will expect to evaporate additional water and produce less waste form volume.

The fabricated samples consisted of two different sizes. One size was the ASTM C-39 ${ }^{[13]}$ standard 2-inch-diameter and 4-inch-length cylinders. The smaller set of samples consisted of 1.9-centimeter-diameter and 4-centimeter-length cylinders. The larger set was used for measurements of density, porosity, compressive strength, and freeze-thaw stability, while the smaller set was used for all the leaching, diffusivity, and matrix durability tests; i.e., TCLP, ANS 16.1, and PCT.

ASTM standard samples were made one at a time. Table 11 provides the batch weight and volume at each step (adding the neutralizers and reagents, partially evaporating excess waste water content, and then mixing the ceramic binder). 
Smaller samples were made at the same batch scale, but were poured in smaller cylinders.

Table 11 also shows the volume reduction achieved from partial dewatering, the volume increase from the addition of ceramic binder mix, and the net volume reduction from the overall trial process. There was no significant volume change during setting.

Table 11-Batch Process Data for SBW and HSW Immobilization

\begin{tabular}{|c|c|c|c|c|}
\hline \multirow{2}{*}{ Process Step } & \multicolumn{2}{|c|}{ SBW } & \multicolumn{2}{|c|}{ HSW } \\
\hline & $\begin{array}{c}\text { Initial } \\
\text { Weight/Volume }\end{array}$ & $\begin{array}{c}\text { Final } \\
\text { Weight/Volume }\end{array}$ & $\begin{array}{c}\text { Initial } \\
\text { Weight/Volume }\end{array}$ & $\begin{array}{c}\text { Final } \\
\text { Weight/Volume }\end{array}$ \\
\hline Simulant weight & $364.8 \mathrm{~g}, 300 \mathrm{ml}$ & & $356.4 \mathrm{~g}, 330 \mathrm{ml}$ & \\
\hline Neutralization & $364.8 \mathrm{~g}, 300 \mathrm{ml}$ & $375.2 \mathrm{~g}, 308.5 \mathrm{ml}$ & $356.4 \mathrm{~g}, 330 \mathrm{ml}$ & $402.6 \mathrm{~g}, 371.4 \mathrm{ml}$ \\
\hline Stabilizer addition & $375.2 \mathrm{~g}, 308.5 \mathrm{ml}$ & $384.2 \mathrm{~g}, 315.9 \mathrm{ml}$ & $402.6 \mathrm{~g}, 371.4 \mathrm{ml}$ & $410.3 \mathrm{~g}, 378.5 \mathrm{ml}$ \\
\hline Evaporation & $384.2 \mathrm{~g}, 315.9 \mathrm{ml}$ & $244.2 \mathrm{~g}, 174.4 \mathrm{ml}$ & $410.3 \mathrm{~g}, 378.5 \mathrm{ml}$ & $172.7 \mathrm{~g}, 123.3 \mathrm{ml}$ \\
\hline \multirow[t]{2}{*}{ Binder addition } & $244.2 \mathrm{~g}, 174.4 \mathrm{ml}$ & $474.2 \mathrm{~g}, 230.2 \mathrm{ml}$ & $172.7 \mathrm{~g}, 123.3 \mathrm{ml}$ & $458.7 \mathrm{~g}, 227.1 \mathrm{ml}$ \\
\hline & \multicolumn{2}{|c|}{ SBW } & \multicolumn{2}{|c|}{ HSW } \\
\hline $\begin{array}{l}\text { Volume reduction - } \\
\text { after dewatering }\end{array}$ & \multicolumn{2}{|c|}{$42 \%$} & \multicolumn{2}{|c|}{$63 \%$} \\
\hline $\begin{array}{l}\text { Volume increase - } \\
\text { ceramification }\end{array}$ & \multicolumn{2}{|c|}{$32 \%$} & \multicolumn{2}{|c|}{$84 \%$} \\
\hline $\begin{array}{l}\text { Volume reduction - } \\
\text { total process }\end{array}$ & \multicolumn{2}{|c|}{$23 \%$} & \multicolumn{2}{|c|}{$34 \%$} \\
\hline
\end{tabular}

All samples were cured in ambient conditions for at least 1 week before they were subject to any tests. During this time they were left in the mold uncovered on one end and were taken out after 7 days. The drying on the open end produced some small surface cracking, but this should not significantly affect sample test performance. Per Nuclear Regulatory Commission (NRC) specification ${ }^{[14]}$, waste forms are to be cured for 28 days before conducting tests. Earlier experience indicated that the phosphate waste forms perform well in leaching tests after only 7 days, but they continue to gain strength for several more weeks. Since the strength of these waste forms is significantly higher than the regulatory requirements, and since our project schedule was constrained by the many trials conducted during process selection, 7 days of curing was chosen as a compromise. We expected the 
results would be conservative, and the subsequent tests by PNNL for comparison with other immobilization processes could all be done with the benefit of the full 28 days.

The specimens prepared for PNNL testing were ASTM standard (C-39) size cylinders. The specimens were prepared individually (although they could have been poured from a larger batch), starting with the stimulant provided by PNNL. The amount of simulant, reagent, and binder, and final weight and volume are summarized in Table 11. The samples were labeled as follows:

- The first three letters are SBW or HSW, to identify the stream simulant

- The next two letters are NS, to signify that we did not spike the simulant (we did spike the simulant with surrogate radioactive metals for many of our own tests)

- The next six numbers are the date of preparation, formatted as MMDDYY

- The last number is the specimen number in the package for the given stream

\section{1-4.2 Temperature Profile During Sample Fabrication}

Because the Ceramicrete process is exothermic, it is necessary to ensure that there is no excessive heating from the acid-base reactions that form the ceramic. To monitor the temperature, we conducted a study on a batch (ASTM size) sample during both SBW and HSW waste stream immobilization. A thermocouple was used to determine the temperature at the center of each sample through the evaporation, slurry, mixing, and setting stages until the sample cooled to room temperature. The temperature profiles as a function of time are shown in Figure 1 for SBW and HSW. The profiles show that the temperature rise during mixing is $\sim 5^{\circ} \mathrm{C}$, with a further rise during setting of $\sim 3^{\circ} \mathrm{C}$, or a maximum temperature of $32^{\circ}-33^{\circ} \mathrm{C}$. Westcott et al. ${ }^{[15]}$ conducted a study of the temperature rise at the center of a 55-gallon drum during setting of a composition of 50 percent soil and 50 percent binder. They observed that shortly after the slurry starts heating, it sets into a ceramic at $55^{\circ} \mathrm{C}$ and forms a solid well before boiling occurs. The ceramic once formed continues self-heating; the maximum temperature reached is $82^{\circ} \mathrm{C}$. This has also been the observation in many large-scale commercial applications of Ceramicrete (e.g., roads/bridges and self- 
shielded storage silos for nuclear materials). For this project, the waste forms contain a significant amount of sodium (nominal 2 molar), which slows down the exothermic reaction and helps keep the slurry at lower temperature. Thus, we do not expect excessive heating during SBW and HSW immobilization to become a problem in an industrial-scale operation.

Figure 1-Temperature Profile During Fabrication of SBW and HSW Ceramics
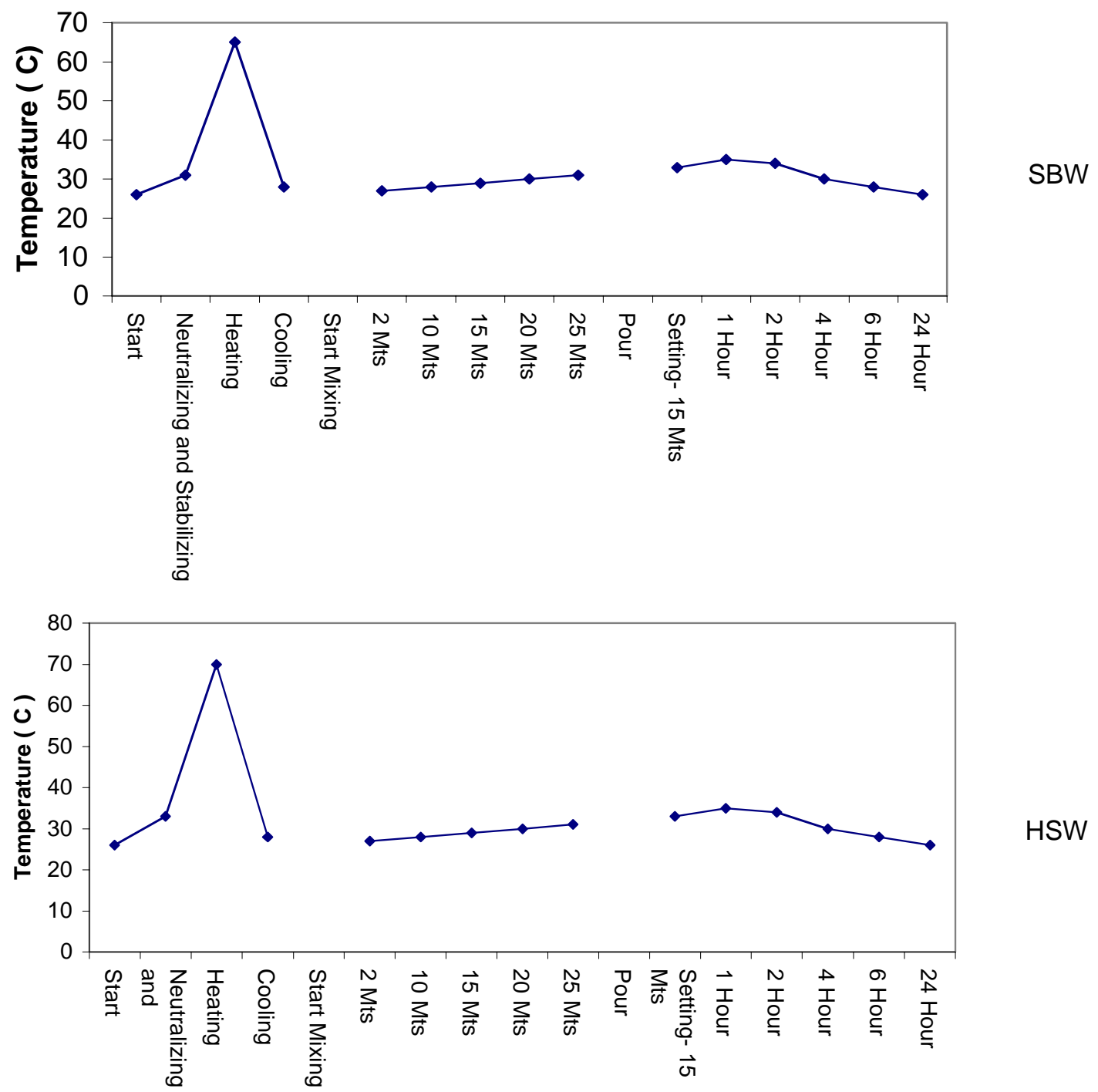

HSW

\section{I-4.3 Study of Off-Gases}

Some of the slurry reactions during the mixing of the prepared waste with Ceramicrete binder are exothermic, but the highest temperature occurs during evaporation prior to mixing. To check for the potential emissions of volatile hazardous or radioactive metals, we collected and analyzed the off-gas generated 
during the evaporation stage. The trial was run at $70^{\circ} \mathrm{C}$ for 4 hours. We expect this approach to be conservative, because the reactions during mixing occur at $<35^{\circ} \mathrm{C}$ for $<1 / 2$ hour. Also, once the reactions occur, non-volatile compounds are formed that are stable at very high temperatures $\left(>700^{\circ} \mathrm{C}\right)$. In large-scale systems, although the waste form reaches $80^{\circ} \mathrm{C}$, the slurry solidifies and forms ceramic at $55^{\circ} \mathrm{C}$, after which no constituent emissions are expected.

For this trial, 100 milliliters of SBW and HSW simulant, provided by PNNL, were prepared for the dewatering step, by adding neutralizer and stabilizer reagents, and poured in a conical flask. The flask was closed with a rubber cork in which two tubes were inserted, one for letting evaporates out and the other for flowing argon gas at 5 psi to drive evaporates into a flask of deionized water. The incoming tube from the waste flask was dipped into the water in the condenser flask so that the vapors will condense in the water. The waste flask was slowly heated at $70^{\circ} \mathrm{C}$ on a hot plate in a fume hood. The waste flask was agitated frequently to ensure that no significant settling occurred during heating. The condensing water was then analyzed for the hazardous and radioactive constituents, using ICP-MS. The results are presented in Tables 12 and 13. We checked for metals but not for sulfide or NOx concentrations. Earlier tests in Russia on high-nitrate salt wastes found only trace amounts of NOx, well below regulated levels. Two samples of each stimulant were tested, one "as received" and one spiked with radioactive surrogates to be sure their emissions would be detectable.

Table 12-SBW Off-Gas Analysis Amounts of waste constituents in the prepared SBW (i.e., with neutralizer and reagents), in the condensed off-gas, and the fraction of constituent that evaporated, with respect to its original content in the waste.

\begin{tabular}{|l|l|l|l|l|l|l|}
\hline \multirow{2}{*}{ Elements } & \multicolumn{2}{|c|}{$\begin{array}{c}\text { In Prepared SBW } \\
(\mu \mathrm{g} / \mathrm{L})\end{array}$} & \multicolumn{2}{c|}{$\begin{array}{c}\text { In Condensate } \\
(\mu \mathrm{g} \text { per L SBW) }\end{array}$} & \multicolumn{2}{c|}{$\begin{array}{c}\text { Fraction Evaporated at } \\
\mathbf{7 0}^{\circ} \text { C in 4 Hours }\end{array}$} \\
\hline & Unspiked & Spiked & Unspiked & Spiked & Unspiked & Spiked \\
\hline $\mathrm{Cr}$ & $1.65 \mathrm{E}+5$ & $1.65 \mathrm{E}+5$ & 1.64 & 7.18 & $1.01 \mathrm{E}-5$ & $6.3 \mathrm{E}-5$ \\
\hline $\mathrm{Cs}$ & 23.4 & $9.5 \mathrm{E}+4$ & 1.03 & 4.73 & 0.044 & $6.84 \mathrm{E}-5$ \\
\hline $\mathrm{Ag}$ & $43+8 \mathrm{E}+6$ & $43+8 \mathrm{E}+6$ & $<0.087$ & 4.89 & None & $6.1 \mathrm{E}-7$ \\
\hline $\mathrm{Cd}$ & $7.55 \mathrm{E}+4$ & $7.55 \mathrm{E}+4$ & 0.464 & 4.36 & $6.14 \mathrm{E}-6$ & $8.37 \mathrm{E}-5$ \\
\hline $\mathrm{Ce}$ & 782 & $9.8 \mathrm{E}+4$ & 0.291 & 4.62 & $3.72 \mathrm{E}-4$ & $4.29 \mathrm{E}-5$ \\
\hline $\mathrm{Re}$ & 637 & $9.2 \mathrm{E}+4$ & $<0.058$ & 3.40 & $<9.1 \mathrm{E}-5$ & $3.2 \mathrm{E}-5$ \\
\hline
\end{tabular}




\begin{tabular}{|l|l|l|l|l|l|l|} 
& \multicolumn{2}{|c|}{$\begin{array}{c}\text { In Prepared SBW } \\
\text { Elements }\end{array}$} & \multicolumn{2}{c|}{$\begin{array}{c}\text { In Condensate } \\
(\mu \mathrm{g} \text { per } \mathbf{L} \text { SBW })\end{array}$} & \multicolumn{2}{c|}{$\begin{array}{c}\text { Fraction Evaporated at } \\
\mathbf{7 0} \text { C in 4 Hours }\end{array}$} \\
\hline $\mathrm{Hg}$ & $3.3 \mathrm{E}+5$ & $3.3 \mathrm{E}+5$ & 3.9 & 111.9 & $1.18 \mathrm{E}-5$ & $3.39 \mathrm{E}-4$ \\
\hline $\mathrm{I}$ & $3.43 \mathrm{E}+3$ & $1.02 \mathrm{E}+5$ & $<29$ & 652.5 & $<8.45 \mathrm{E}-3$ & $6.3 \mathrm{E}-3$ \\
\hline $\mathrm{Pb}$ & $2.74 \mathrm{E}+5$ & $2.74 \mathrm{E}+5$ & 6.49 & 495.9 & $2.36 \mathrm{E}-5$ & $1.8 \mathrm{E}-3$ \\
\hline $\mathrm{Na}$ & $\begin{array}{l}5.05 \mathrm{E}+7 \\
+3.95 \mathrm{E}+6\end{array}$ & $\begin{array}{l}5.05 \mathrm{E}+7 \\
+3.95 \mathrm{E}+6\end{array}$ & $8.97 \mathrm{E} 3$ & $4.65 \mathrm{E}+3$ & $1.64 \mathrm{E}-4$ & $8.5 \mathrm{E}-5$ \\
\hline $\mathrm{Al}$ & $1.87 \mathrm{E}+7$ & $1.87 \mathrm{E}+7$ & 78.3 & 952.6 & $4.18 \mathrm{E}-6$ & $5.09 \mathrm{E}-5$ \\
\hline
\end{tabular}

Table 13-HSW Off-Gas Analysis

Amounts of waste constituents in the prepared HSW (i.e., with neutralizer and reagents), in the condensed off-gas, and the fraction of constituent that evaporated, with respect to its original content in the waste.

\begin{tabular}{|c|c|c|c|c|c|c|}
\hline \multirow[t]{2}{*}{ Elements } & \multicolumn{2}{|c|}{$\begin{array}{c}\text { In Prepared HSW } \\
(\mu g / L)\end{array}$} & \multicolumn{2}{|c|}{$\begin{array}{l}\text { In Condensate } \\
\text { ( } \mu \text { g per L HSW) }\end{array}$} & \multicolumn{2}{|c|}{$\begin{array}{c}\text { Fraction Evaporated } \\
\text { at } 70^{\circ} \mathrm{C} \text { in } 4 \text { Hours }\end{array}$} \\
\hline & Unspiked & Spiked & Unspiked & Spiked & Unspiked & Spiked \\
\hline $\mathrm{Cr}$ & 671 & 671 & 1.653 & 3.393 & $2.46 \mathrm{E}-3$ & 5.05E-3 \\
\hline Cs & 17 & $9.5 \mathrm{E}+4$ & 1.183 & 5.278 & 0.069 & $5.27 \mathrm{E}-5$ \\
\hline $\mathrm{Ag}$ & $\begin{array}{l}2.38 \mathrm{E}+4 \\
+8 \mathrm{E}+6\end{array}$ & $\begin{array}{l}2.38 \mathrm{E}+4 \\
+8 \mathrm{E}+6\end{array}$ & 0.139 & 25.23 & None & $3.1 \mathrm{E}-6$ \\
\hline $\mathrm{Cd}$ & 395 & 395 & 0.894 & $<0.377$ & $2.26 \mathrm{E}-3$ & $<9.55 \mathrm{E}-4$ \\
\hline $\mathrm{Ce}$ & 2.05 & $9.8 \mathrm{E}+4$ & & $<0.64$ & & $<6.4 \mathrm{E}-6$ \\
\hline $\mathrm{Re}$ & 125 & $9.2 \mathrm{E}+4$ & 0.136 & 3.75 & $1.088 \mathrm{E}-3$ & 3.74E-5 \\
\hline $\mathrm{Hg}$ & 99.7 & 99.7 & 2.146 & 26.25 & 0.0215 & 0.26 \\
\hline I & $<20$ & $1.02 E+5$ & $<29$ & 15.8 & None & $1.58 \mathrm{E}-4$ \\
\hline $\mathrm{Pb}$ & $2.42 E+4$ & $2.42 E+4$ & 15.08 & 7.98 & $6.23 \mathrm{E}-4$ & $3.29 E-4$ \\
\hline $\mathrm{Na}$ & 4.89E7 & 4.89E7 & 9.01E03 & $3.19 E+3$ & $1.85 \mathrm{E}-4$ & 6.33E-5 \\
\hline $\mathrm{Al}$ & 1.23E5 & 1.23E5 & 66.26 & 176.9 & $5.38 \mathrm{E}-4$ & $1.43 \mathrm{E}-3$ \\
\hline
\end{tabular}

The data are not entirely consistent with expected results. For certain samples, the calculations show large differences between the off-gas from the spiked and unspiked preparations of both SBW and HSW. Yet the spiked versions are the same as the unspiked, except for the four surrogates. Also, the calculated evaporation fractions for some elements, although small in most cases, seem higher than reasonable at $70^{\circ} \mathrm{C}$.

One possible source of uncertainty in these data is contamination from the laboratory resources. New containers, stoppers, and tubing were used, but were not analyzed for contamination before running the trial. After the trial, we checked for Cs contamination in the deionized water, and found levels that alone could produce the 
observed data without any evaporate. Also, we observed that an apparent high evaporation fraction occurred in cases where the concentration in the waste was very small (on the order of $100 \mathrm{ppb}$ ). Inaccuracy may be introduced when dividing two very small evaporate and waste content measurements.

We calculated evaporation ratios of a fraction of 1 percent for $\mathrm{Pb}$ in one of the two SBW samples, and for $\mathrm{Cd}, \mathrm{Re}$, and $\mathrm{Al}$ in one of the two HSW samples. The iodine result differs between SBW and HSW (only the spiked samples yielded data in the detectable range). These results are noted and additional testing is indicated to resolve these discrepancies between samples. The results for $\mathrm{Hg}$ also differed between SBW and HSW, and were particularly high in both HSW samples (although there was an order of magnitude discrepancy). The results for $\mathrm{Cr}$ were similar. Since the concentrations of $\mathrm{Hg}$ and $\mathrm{Cr}$ were very small in $\mathrm{HSW}$, we did not add any reagent to HSW to make these less soluble. While that is one possible answer, this needs to be evaluated more carefully.

We also note that the ICP-MS method is very accurate for the heavy elements $(Z>26)$, so there is some uncertainty in the data for $\mathrm{Cr}, \mathrm{Na}$, and $\mathrm{Al}$.

A single trial run for each waste is obviously not sufficient; a more systematic and detailed trial, beginning with high concentrations of these metals, is recommended.

\section{I-5 Characteristics of the Ceramic Waste Forms}

\section{I-5.1 Physical Properties}

The waste form appearance was very dense, or non-porous. Density was calculated from sample weight and volume. The open porosity was measured by the water immersion method. The compressive strength was measured on three, 2-inchdiameter and 4-inch-length (ASTM standard) cylinders ${ }^{[13]}$. Physical properties of the waste forms are given in Table 14. Three samples were tested for compressive strength. 
Table 14-Physical Properties of Waste Forms

\begin{tabular}{|l|l|l|l|l|}
\hline Waste & \multicolumn{1}{|c|}{$\begin{array}{c}\text { Density } \\
\left(\mathbf{g} / \mathbf{c m}^{\mathbf{3}}\right)\end{array}$} & $\begin{array}{l}\text { Open Porosity } \\
\text { 21-Day Compressive } \\
\text { Strength (psi); 3 Samples }\end{array}$ & \multicolumn{1}{|c|}{ Color } \\
\hline SBW & 2.02 & zero & $4408 ; 4655 ; 4748$ & Black \\
\hline HSW & 2.06 & zero & $3956 ; 4114 ; 4158$ & Black \\
\hline
\end{tabular}

The density ${ }^{[16]}$ indicates that the waste forms are light-weight ceramics, with almost no connected porosity. Both waste forms exhibit a compressive strength that is much higher than the required 3.45 MPa ( $500 \mathrm{psi})$. Earlier studies have shown that the strength keeps rising, even after 3 weeks ${ }^{[12]}$.

The open porosity measurement ${ }^{[16]}$ was zero; that is, non detectable, indicating these samples are nonporous and essentially non-permeable to water under normal pressure. Water permeability measured on similar samples in other projects was found to be as low as 0.04 millidarcies. This indicates that the Ceramicrete waste forms are very dense; hence, highly superior waste forms for resistance to degradation processes.

The compressive strength of the specimens was $>4,000$ psi, much higher than the minimum strength of 500 psi needed for waste forms. The strength loss upon immersion after 3 days was less than 25 percent. Longer-term immersion should not degrade the waste form strength significantly, since the ceramic does not accept water once formed.

Freeze-thaw stability of the waste forms was measured according the protocol ASTM B-553 ${ }^{[17]}$. As prescribed by the NRC ${ }^{[14]}$, three specimens of each waste form were tested. These cylinders were cured for 3 weeks and placed in the freeze-thaw chamber. The cylinders were alternately cooled, heated, and held-in 1 hour increments-at $+24^{\circ} \mathrm{C},-30^{\circ} \mathrm{C},+24^{\circ} \mathrm{C},+60^{\circ} \mathrm{C}$, and $+24^{\circ} \mathrm{C}$, such that the cycle period was 8 hours. After completion of 30 cycles, the specimens were visually checked for any obvious defects and cracks. No such defects or cracks or any bulk disintegration of the specimens were observed. The specimen compressive strength was then measured. The strength data averaged 2,230 psi and 2,057 psi for SBW and HSW, respectively (actual data were 2,194, 2,242, and 2,253 psi for SBW; and 
1,952, 2,048, and 2,170 psi for HSW). The strength decreased approximately 50 percent, thus remaining more than 4 times stronger than the required $500 \mathrm{psi}$ minimum for this test.

\section{I-5.2 Leaching Performance of the Waste Forms (Spiked Waste)}

During early trials on the simulants supplied by PNNL, the leach test results were often below the normal detection limits. Therefore, for the tests reported below, the simulants were spiked with surrogates of Tc, Cs, I, and actinides at $\sim 100 \mathrm{mg} / \mathrm{L}$. Leaching tests were conducted on samples cured for 7 days, in order to make up for lost schedule during the trials phase of this project. The standard cure period is 28 days, during which time waste forms typically become more durable. Therefore, we expect that the results reported here are conservative; results on fully cured (28day) samples should be the same or better.

\section{I-5.2.1 TCLP Test}

This protocol ${ }^{[18]}$ tests the ability of the crushed waste form to retain hazardous constituents in a slightly acidic environment. Along with the hazardous constituents $\mathrm{Cr}, \mathrm{Cd}, \mathrm{Hg}$, and $\mathrm{Pb}$, for which the test is recommended, we also measured the levels of fission products and TRU elements in the leachate to gain additional insight in the performance of the Ceramicrete matrix. The results, along with the UTS limits, are presented in Table 15.

Table 15-TCLP Test Results ( $\mu \mathrm{g} / \mathrm{L})$

\begin{tabular}{|l|l|l|l|}
\hline \multicolumn{1}{|c|}{ Constituent } & \multicolumn{1}{|c|}{ In SBW Leachate } & In HSW Leachate & \multicolumn{1}{c|}{ UTS Limit $^{+}$} \\
\hline $\mathrm{Cr}$ & $<1.82$ & 53.3 & 600 \\
\hline $\mathrm{Cd}$ & $<0.28$ & $<0.28$ & 110 \\
\hline $\mathrm{Cs}$ & 36.1 & 47.2 & \\
\hline $\mathrm{Ag}$ & 3.45 & 7.79 & 140 \\
\hline $\mathrm{Ce}$ & 0.10 & 0.16 & \\
\hline $\mathrm{Re}$ & 16.3 & 3.59 & \\
\hline $\mathrm{Hg}$ & $<7.66$ & $<7.66$ & 25 \\
\hline $\mathrm{Pb}$ & 1.47 & 9.64 & 750 \\
\hline $\mathrm{I}$ & 98.3 & 5.81 & \\
\hline
\end{tabular}

${ }^{+}$Ref. Code of Federal Register 40 CFR Part 268.48 
Comparison of the leaching results with the regulatory limits for the hazardous metals shows that the leaching levels are well below the required limits. The levels of surrogates representing fission products and TRU elements are also very low. This indicates that the immobilization of constituents was as we expected from extensive prior testing on other types of wastes.

\section{I-5.2.2 ANS 16.1 Test}

This protocol ${ }^{[19]}$ tests diffusivity and surface release of constituents in a monolithic waste form. This test is required for HSW but not SBW. The smaller-size HSW samples were washed with deionized water, wiped, and then immersed in a volume of water 20 times that of the sample. The samples were moved from one leachate water to another at the periods prescribed in the procedure. Nine leachate aliquots for each sample were collected after 7 days and analyzed. This gives a conservative result, since the near-surface constituents leach first. We expect the results would improve as the data for the full 90-day test period are included. Table 16 summarizes the leaching indices (LI) for the radioactive surrogates. For cerium, the leachate was too low to detect using ICP-MS, so the leaching index could not be calculated.

Table 16-7-Day LI for Radioactive Surrogates and Sodium for Spiked HSW Waste Forms

\begin{tabular}{|l|l|l|l|l|l|}
\multicolumn{1}{c|}{ Waste Form } & \multicolumn{1}{c|}{ lodine } & \multicolumn{1}{c|}{ Cesium } & \multicolumn{1}{c|}{ Rhenium } & \multicolumn{1}{c|}{ Ce } & \multicolumn{1}{c|}{ Sodium } \\
\hline HSW & 11.21 & 11.5 & 12.74 & Non-detect: & 7.13 \\
${ }{ }^{[20]} }$ & 11 & & 9 & $<0.04 \mathrm{ppb}$ & 6 \\
\hline
\end{tabular}

The HSW waste form satisfies the minimum requirements ${ }^{[20]}$ for Tc, I, and $\mathrm{Na}$ prescribed by DOE, even with only 7 days of curing and 7 days of leaching results. It has been observed by others ${ }^{[11]}$ that the leaching index is non-linear with respect to the constituent concentration. That is, the results obtained for the spiked HSW would be even better if we had run the test for HSW with the much lower levels of radioactive constituents specified in the RFP. As mentioned above, these constituents were too low to detect using our methods (ICP-MS).

Follow-on tests using the ANS 16.1 protocol could be conducted on spiked SBW waste forms. Based on our previous experience with other wastes, we expect that 
the reagent additives would have to be further adjusted for the constituents in SBW. That chemistry needs to be looked at more carefully. For this project, our focus for the ANS 16.1 test was on the requirements for HSW.

\section{1-5.2.3 Product Consistency Test}

The $\mathrm{PCT}^{[21]}$ is conducted on spiked SBW and HSW samples that were cured for 7 days. Crushed samples were immersed in deionized water and kept at $90^{\circ} \mathrm{C}$ for 7 days in the standard air-tight PCT leachate vessel. After 7 days, the sample was removed and the leachate was analyzed for $\mathrm{pH}$ and the structural components of the Ceramicrete matrix.

Since the PCT protocol is designed to test for structural degradation, we tested for $\mathrm{Mg}, \mathrm{K}$, and $\mathrm{P}$, the elements that form the Ceramicrete matrix (just as one would test for the $\mathrm{B}, \mathrm{Li}, \mathrm{Na}$, and $\mathrm{Si}$ in a borosilicate glass waste form). Reacted waste constituents are chemically bonded in Ceramicrete but are not performance indicators of the matrix, per se.

Special steps must be taken when applying the PCT to alternative waste forms, since the protocol was originally designed for borosilicate glass. Ceramic crushes differently than glass, yielding a very different particle size distribution. The washing procedure runs the risk of releasing key matrix chemicals differently than glass. For conservatism, it is best not to wash the particles; however, we did wash some samples so that the wash can be analyzed if wanted for future reference to confirm the effect of washing. A measured particle surface area, not the standard glass surface area, should be used to normalize the measured leach data. For conservatism, the pore space surface area should not be included in the normalization calculation, until further work can determine whether the pore surfaces participate in the matrix degradation process. In fact, the surface area, including the pore spaces, was measured separately and found to differ only slightly, which is consistent with the observation of very low porosity. This has been shown in our earlier studies ${ }^{[3]}$ and presented with discussion among testing laboratory experts at the 2004 International Conference on alternative Nuclear Waste Forms ${ }^{[22]}$. The data reported for this project are based on the conservative procedures described here. 
We have found that many data reported in publications and presentations on alternative waste forms were not based on these conservative principles and may be off by an order of magnitude.

The surface area was measured by the sedigraph method from a portion of the crushed ceramic waste forms. The sedigraph method allows measurement of the surface area of the grains with and without pores; the surface area of the grains without the pore surface area was used in our calculations. The normalized leaching rates are presented in Table 17; in order to analyze the lighter elements $\mathrm{Mg}, \mathrm{K}$, and $\mathrm{P}$, and $\mathrm{Na}$ and $\mathrm{NO}_{3}$, ICP-AES was used.

Table 17-Normalized Leaching Rates $\left(\mathrm{g} / \mathrm{m}^{2} . \mathrm{d}\right)$ per the PCT

\begin{tabular}{|l|l|l|l|l|l|l|l|}
\hline $\begin{array}{c}\text { Waste } \\
\text { Form }\end{array}$ & $\begin{array}{c}\text { Surface Area } \\
\left(\mathbf{m}^{2} / \mathbf{g}\right)\end{array}$ & \multicolumn{1}{|c|}{$\mathbf{p H}$} & \multicolumn{1}{|c|}{$\mathbf{M g}$} & \multicolumn{1}{|c|}{$\mathbf{K}$} & \multicolumn{1}{|c|}{$\mathbf{P}$} & \multicolumn{1}{|c|}{$\mathbf{N a}$} & \multicolumn{1}{|c|}{$\mathbf{N O}_{\mathbf{3}}$} \\
\hline SBW & 40.6 & 8.9 & $2.44 \mathrm{E}-6$ & $1.17 \mathrm{E}-3$ & $5.08 \mathrm{E}-4$ & $3 \mathrm{E}-3$ & $2.16 \mathrm{E}-3$ \\
\hline HSW & 10.9 & 10.6 & $1.7 \mathrm{E}-5$ & $7.75 \mathrm{E}-3$ & $5.2 \mathrm{E}-3$ & $2.09 \mathrm{E}-2$ & N/A \\
\hline
\end{tabular}

The SBW leachate is near $\mathrm{pH}$ neutral. This is a good indication that the waste form produced by this technology will be stable within the repository and will not contribute to potential corrosion issues. HSW has more binder with wollastonite, as discussed earlier, which causes the higher $\mathrm{pH}$. The $\mathrm{pH}$ would be reduced for both wastes by using fly ash instead, as we have recommended. There is some concern now at the Office of Civilian Radioactive Waste Management (OCRWM) that the repository environment should be neutral, and the CPBC waste form would be consistent with efforts to achieve neutrality to the extent possible.

The results of the tests, conducted on the major components of the matrix, Mg, K, and $\mathrm{P}$, as well as on other significant components of the waste streams, such as $\mathrm{Na}$ and $\mathrm{NO}_{3}$, show that the normalized leaching rates are well below the $0.2 \mathrm{grams} / \mathrm{m}^{2} . \mathrm{d}$ (mass loss as $U$ ) that was originally required of ceramic waste forms for the planned Immobilization/Can-in-Canister project at Savannah River ${ }^{[23,24]}$. For borosilicate glass forms, the geologic repository target criteria are in the range of 0.16 to 0.4 $\mathrm{g} / \mathrm{m}^{2} . \mathrm{d}$, depending on the particular structural element $(\mathrm{Si}, \mathrm{Na}, \mathrm{Li} \text {, and } \mathrm{B})^{[25,26]}$. The Hanford low-activity waste (LAW) criterion for disposal is $0.28 \mathrm{~g} / \mathrm{m}^{2} . \mathrm{d}^{[27]}$. The results shown in Table 17 are well below the limits required of immobilized HLW and LAW, a 
strong indication that the ceramic matrix that binds hazardous and radioactive constituents is very durable.

\section{I-6 Summary of Ceramic Waste Form Properties and Performance}

Table 18 summarizes the characteristics of the ceramic waste forms that we prepared from SBW and HSW at room temperature (these data are also presented in Tables 10, 11, 14-17, and 19-20).

Table 18-Summary of Waste Form Characteristics

\begin{tabular}{|c|c|c|}
\hline Property & SBW & HSW \\
\hline Color & Black & Black \\
\hline Density $\left(\mathrm{g} / \mathrm{cm}^{3}\right)$ & 2.02 & 2.06 \\
\hline Open porosity & Non detectable & Non detectable \\
\hline 21-day compressive strength (psi) & 4,603 & 4,076 \\
\hline $\begin{array}{l}\text { Waste load factor (wt.\%) } \\
\text { - wet basis } \\
\text { - dry basis } \\
\text { - as if oxidized }\end{array}$ & $\begin{array}{l}47 \\
23 \\
25\end{array}$ & \begin{tabular}{|l|}
26 \\
8 \\
10 \\
\end{tabular} \\
\hline Volume reduction - after dewatering & $42 \%$ & $63 \%$ \\
\hline Volume increase - ceramification & $32 \%$ & $84 \%$ \\
\hline Volume reduction - total process & $23 \%$ & $34 \%$ \\
\hline TCLP ( $\mu \mathrm{g} / \mathrm{L})$ (spiked simulant) & $\begin{array}{l}\mathrm{Pb}=1.47 ; \mathrm{Cr}, \mathrm{Cd}, \\
\mathrm{Hg}=\text { non-detect. All } \\
\text { pass UTS standards }\end{array}$ & $\begin{array}{l}\mathrm{Cr}=53.3 ; \mathrm{Pb}=9.64 ; \mathrm{Cd}, \\
\mathrm{Hg}=\text { non-detect. All pass UTS } \\
\text { standards }\end{array}$ \\
\hline $\begin{array}{l}\text { ANS } 16.1 \text { Leaching Index }-7 \text { day } \\
\text { (spiked simulant) }\end{array}$ & & $\begin{array}{l}\mathrm{I}=11.2 ; \mathrm{Re}=12.7 ; \mathrm{Na}=7.19 \\
(\mathrm{Cs}=11.5 ; \mathrm{Ce}=\text { non detect })\end{array}$ \\
\hline $\begin{array}{l}\text { PCT leaching rate }\left(\mathrm{g} / \mathrm{m}^{2}-\mathrm{d}\right) \text { (spiked } \\
\text { simulant) }\end{array}$ & $\begin{array}{l}(\mathrm{pH}=8.9) \mathrm{Mg}=2.44 \mathrm{E}-6 ; \mathrm{K} \\
=0.00117 ; \mathrm{P}=5.08 \mathrm{E}-4(\mathrm{Na} \\
\left.=0.003 ; \mathrm{NO}_{3}=0.00216\right)\end{array}$ & $\begin{array}{l}(\mathrm{pH}=10.6) \mathrm{Mg}=1.7 \mathrm{E}-5 ; \\
\mathrm{K}=0.00775 ; \mathrm{P}=0.0052 ; \\
(\mathrm{Na}=0.0209)\end{array}$ \\
\hline
\end{tabular}

Load Factor and Volume Reduction.

The waste load factors for SBW and HSW by weight/wet basis include the water remaining in the waste after partial evaporation, plus conversion of binder to water as in Table 1. This is the true measure for the CBPC process we used in this project. The load factors on a dry weight basis are also given in Table 18. In previous studies ${ }^{[1,3,22]}$, we dried the waste forms by heating at $\sim 120^{\circ} \mathrm{C}$ to confirm that strength and leaching properties are not affected (i.e., unlike grout waste forms, water does not participate in the structure). Above $120^{\circ} \mathrm{C}$ the waste form is anhydrous, and no further change occurs. For comparison with thermal oxidation processes (e.g., 
vitrification), the mass loading based on waste constituents as if oxidized (dry basis) in the waste form (wet basis) is also given in Table 18. This is the mass of waste constituents as if they had been oxidized per unit mass of waste form. The as-ifoxidized mass is calculated on a dry weight basis, and the waste form mass is calculated on a wet basis since the waste form includes water. The waste constituent data for the as-if-oxidized calculations are given in Tables 19 and 20. This calculation can not be compared on a consistent unit basis with glass (i.e., dry:wet rather than dry:dry).

Table 19-HSW Constituents as if Oxidized (based on one liter HSW)

\begin{tabular}{|c|c|c|}
\hline Constituent & In Waste (g) & In Waste Form (g) \\
\hline $\mathrm{B}_{2} \mathrm{O}_{3}$ & $1.15 \mathrm{E}-3$ & $1.15 \mathrm{E}-3$ \\
\hline $\mathrm{Na}_{2} \mathrm{O}$ & 65.6 & 65.6 \\
\hline $\mathrm{Al}_{2} \mathrm{O}_{3}$ & 0.232 & 0.232 \\
\hline $\mathrm{Cr}_{2} \mathrm{O}_{3}$ & $9.08 \mathrm{E}-4$ & $9.08 \mathrm{E}-4$ \\
\hline $\mathrm{CdO}$ & $4.5 \mathrm{E}-4$ & $4.5 \mathrm{E}-4$ \\
\hline $\mathrm{Cs}_{2} \mathrm{O}$ & $1.8 \mathrm{E}-5$ & $1.8 \mathrm{E}-5$ \\
\hline $\mathrm{CeO}_{2}$ & $2.51 \mathrm{E}-6$ & $2.51 \mathrm{E}-6$ \\
\hline $\mathrm{ReO}_{2}$ & $1.46 \mathrm{E}-4$ & $1.46 \mathrm{E}-4$ \\
\hline $\mathrm{HgO}_{2}$ & $1.02 \mathrm{E}-4$ & $1.02 \mathrm{E}-4$ \\
\hline $\mathrm{Fe}_{2} \mathrm{O}_{3}$ & $8.99 \mathrm{E}-4$ & $8.99 \mathrm{E}-4$ \\
\hline $\mathrm{PbO}$ & 0.025 & 0.025 \\
\hline \multicolumn{3}{|l|}{$1 O_{2}$} \\
\hline $\mathrm{Ag}_{2} \mathrm{O}$ & $2.66 \mathrm{E}-2$ & $2.66 \mathrm{E}-2$ \\
\hline $\mathrm{K}_{2} \mathrm{O}$ & $1.25 \mathrm{E}-3$ & $1.25 \mathrm{E}-3$ \\
\hline $\mathrm{CO}_{3}^{-}$ & 60 & 60 \\
\hline $\mathrm{NO}_{3}$ & 1.55 & 1.55 \\
\hline TOC & 13.86 & 13.86 \\
\hline $\mathrm{H}_{2} \mathrm{O}$ & 925.9 & 203.2 \\
\hline $\mathrm{MgO}$ & & 155.7 \\
\hline $\mathrm{KH}_{2} \mathrm{PO}_{4}$ & & 500.0 \\
\hline $\mathrm{CaSiO}_{3}$ & & 200.0 \\
\hline $\mathrm{SnCl}_{2}$ & & 6.5 \\
\hline $\mathrm{Ag}-\mathrm{Z}$ & & 16.5 \\
\hline $\mathrm{H}_{3} \mathrm{PO}_{4}$ & & 140.0 \\
\hline Total & 1067.20 & 1363.0 \\
\hline
\end{tabular}


Table 20-SBW Constituents as if Oxidized (based on one liter SBW)

\begin{tabular}{|c|c|c|}
\hline Constituent & In Waste (g) & In Waste Form (g) \\
\hline $\mathrm{B}_{2} \mathrm{O}_{3}$ & 0.38 & 0.38 \\
\hline $\mathrm{Na}_{2} \mathrm{O}$ & 68.06 & 68.06 \\
\hline $\mathrm{Al}_{2} \mathrm{O}_{3}$ & 35.3 & 35.3 \\
\hline $\mathrm{Cr}_{2} \mathrm{O}_{3}$ & 0.241 & 0.241 \\
\hline $\mathrm{CdO}$ & 0.085 & 0.085 \\
\hline $\mathrm{Cs}_{2} \mathrm{O}$ & 2.48E-05 & 2.48E-05 \\
\hline $\mathrm{CeO}_{2}$ & $9.60 \mathrm{E}-04$ & $9.60 \mathrm{E}-04$ \\
\hline $\mathrm{ReO}_{2}$ & 7.46E-04 & 7.46E-04 \\
\hline $\mathrm{HgO}_{2}$ & 0.343 & 0.343 \\
\hline $\mathrm{CaO}$ & 2.95 & 2.95 \\
\hline $\mathrm{MnO}_{2}$ & 1.03 & 1.03 \\
\hline $\mathrm{PbO}$ & 0.29 & 0.29 \\
\hline $\mathrm{F}$ & 0.83 & 0.83 \\
\hline $\mathrm{Cl}$ & 1.15 & 1.15 \\
\hline $\mathrm{Fe}_{2} \mathrm{O}_{3}$ & 1.44 & 1.44 \\
\hline $\mathrm{IO}_{2}$ & 4.29E-03 & 4.29E-03 \\
\hline $\mathrm{Ag}_{2} \mathrm{O}$ & 4.62E-05 & 4.62E-05 \\
\hline $\mathrm{K}_{2} \mathrm{O}$ & 8.55 & 8.55 \\
\hline $\mathrm{SO}_{4}$ & 5.15 & 5.15 \\
\hline $\mathrm{NO}_{3}$ & 269 & 269 \\
\hline $\mathrm{H}_{2} \mathrm{O}$ & 811.8 & 345.2 \\
\hline $\mathrm{MgO}$ & 0.616 & 146.5 \\
\hline $\mathrm{KH}_{2} \mathrm{PO}_{4}$ & & 439.4 \\
\hline $\mathrm{CaSiO}_{3}$ & & 179.7 \\
\hline $\mathrm{Na}_{2} \mathrm{~S}$ & & 6.6 \\
\hline $\mathrm{SnCl}_{2}$ & & 6.6 \\
\hline $\mathrm{Ag}-\mathrm{Z}$ & & 16.6 \\
\hline $\mathrm{NaOH}$ & & 34.8 \\
\hline Total & 1207.22 & 1570.2 \\
\hline
\end{tabular}

Mass loading as if constituents oxidized (dry basis) in waste form (wet basis):

$(1207.22-811.8) /(1570.2)=395.4 / 1570.2=25.2 \%$

It is not the load factor, but rather the volume reduction factor that dictates the economic feasibility of alternative technologies. For that matter, a valid final volume economic comparison between technology options can only be made when the total 
waste volumes derived from preparation, pre-treatment, separation, off-gas treatment, and associated processes are factored in as well. The volume impact of each step in the process is shown in Table 11. Table 18 summarizes the percentage decrease after partial dewatering, increase after adding Ceramicrete binder, and overall decrease relative to the simulant as-received. All indications from our trial runs are that we could have dewatered the simulant further, added less Ceramicrete, and achieved a greater volume reduction.

\section{Leaching.}

Regarding the leach test data in Table 18, it was necessary to spike the wastes with surrogates for the radioactive constituents in order to detect these constituents using the ICP-MS and ICP-AES methods. Even so, cerium was not detectable in the ANS 16.1 test. This is not surprising; we have found from many previous studies on DOE wastes and Russian wastes that $\mathrm{Pu}$ and $\mathrm{U}$ are particularly well immobilized by Ceramicrete.

A small amount of non-hazardous substance was observed on the surface and in the water after immersion of the specimens for a few weeks. We examined this substance using XRD and identified it as $\mathrm{Na}_{2} \mathrm{HPO}_{4}$ (see Figure 2). This can be avoided by neutralizing the wastes to $\mathrm{pH} 4$ or less, rather than to $\mathrm{pH} 5$ as we had done. This was explained in Section I-3.1. Based on the results of our leach and strength tests, this phenomenon should not adversely affect the ability of the CBPC waste form to retain hazardous and radioactive constituents.

Figure 2-X-ray Identification of non-hazardous Na residue resulting from partial neutralization to $\mathrm{pH} 5$

\begin{tabular}{|c|c|}
\hline SBW Precipitate XRD & HSW Precipitate \\
\hline 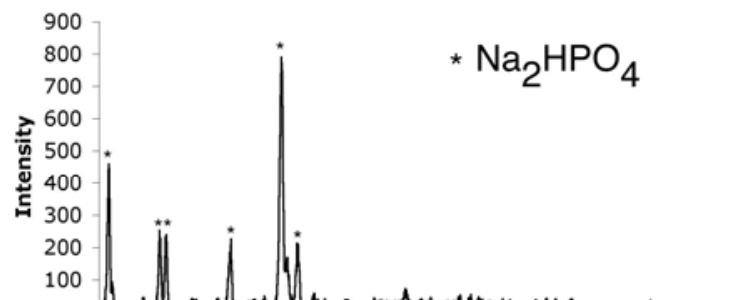 & 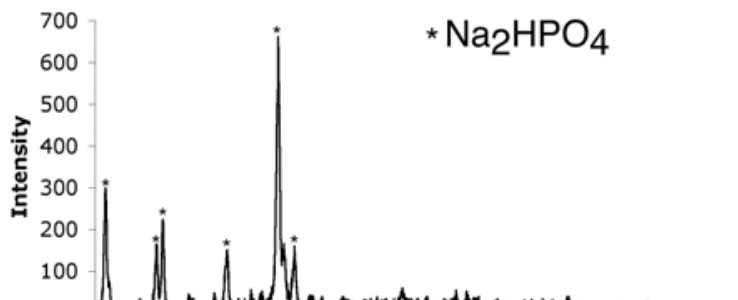 \\
\hline 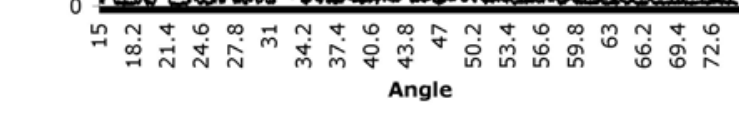 & 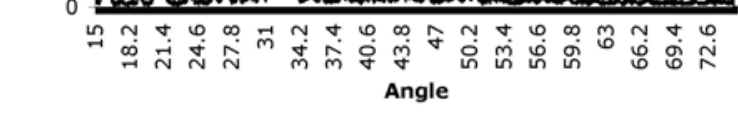 \\
\hline
\end{tabular}




\section{Process and Performance Success.}

Based on the demonstration and testing work performed, the Ceramicrete technology immobilizes both HSW and SBW. The hazardous and radioactive constituents in these wastes, when mixed with Ceramicrete binder and appropriate reagents, are converted into non-leachable phosphates or other insoluble compounds and microencapsulated in a durable mineral matrix. Tests demonstrate that the waste form surpasses the project performance requirements for a versatile, room temperature process, even when the waste is spiked with the key constituents at much higher levels than occur in either HSW or SBW. The same essential process accommodates both acidic and basic wastes with a simple, partial neutralization step.

\section{I-7 Conclusions}

For SBW, the process provides a ready alternative to thermal technologies such as borosilicate glass and steam reforming, at low cost, low operational risk, and higher waste form volume. For HSW, the process provides a method of immobilizing volatile constituents that derive from the vitrification of HLW and LAW. The load factors and potential waste form volume reductions have not been optimized in this project. Indications in the study are that these can be considerably improved without much additional effort with the simple bench setup that we used. This is recommended for further work since it portends a large lifecycle cost savings.

Following are the key points learned from this project:

1. Ceramicrete technology is suitable for immobilizing both SBW and HSW.

2. The durability and leaching tests pass the performance requirements, generally by at least an order of magnitude.

3. Waste form monoliths are dense/non-porous, and hard, exhibiting high strength.

4. Silver zeolite, tin chloride, and sodium sulfide are effective reagents for stabilizing specific constituents in HSW and SBW, including I, Tc, Cr, and $\mathrm{Hg}$. 
Other constituents are stabilized and mineralized in the phosphate matrix itself.

5. The process is carried out at room temperature, except for partial dewatering by evaporation at $\sim 60-70^{\circ} \mathrm{C}$ to help reduce the final volume.

6. Volume reductions of 34 percent for HSW and 23 percent for SBW were realized. Our findings indicate that these can be improved considerably by further dewatering, in turn reducing the amount of binder needed. (In this project, we dewatered the HSW and SBW simulants to 37 percent and 58 percent, respectively, of their original volumes, then increased the reduced stimulants by 84 percent and 32 percent, respectively, with the addition of binder.)

7. The final waste forms are near neutral and thus, non-corrosive during longterm storage and stable during permanent geologic disposal. Our findings indicate that neutrality would be even better achieved by replacing wollastonite with fly ash in the mix.

8. Further studies discussed in this report, indicated by our observations, but not carried to completion in this project, include the following:

a. Dewater waste to optimize the load factor and final waste form volume for HSW and SBW.

b. Reduce the quantities of binder mix, both $\mathrm{MgO} / \mathrm{KH}_{2} \mathrm{PO}_{4}$ and $\mathrm{CaSiO}_{3} / f l y$ ash, to further improve load factor/ceramic volume. For conservatism in this project, we used more than necessary.

c. Optimize the quantities of stabilizer additives to improve the load factor/waste form volume. For this, the chemistry and interaction between these additives and the waste constituents need more consideration.

d. Prepare and test the berlinite ceramic process, especially for SBW and high aluminum wastes, since the theoretical load factor is higher and the final volume is lower than Ceramicrete. For this, the compounds formed by the reactions need to be identified and the reactions better understood. 
e. Perform a sodium concentration sensitivity study to determine whether the theoretical load factor limitation is water content or sodium content.

f. Repeat the off-gas sampling and analysis in more detail in order to obtain systematic, consistent, and reliable results.

g. Replace wollastonite with Class $\mathrm{C}$ or $\mathrm{F}$ fly ash in the binder mix and confirm that the leachate is $\mathrm{pH}$ neutral. We have previously used fly ash on many wastes with success; for this project the ash supply first needs to be characterized for compatibility with HSW and SBW specifications.

h. Adjust the $\mathrm{pH}$ of these high-Na simulants to $\mathrm{pH} \sim 4$ or less to reduce or eliminate residual, un-reacted/un-bound $\mathrm{Na}$ compounds. (Even though they are non-hazardous, we prefer to bind all constituents in the matrix.)

9. Comparative advantages of the ceramic process and CBPC mineral waste forms:

a. Low safety risk and low cost as a room temperature process; low technology/process/operational risk as a mature technology (already in full-scale use in the construction industry and with 10 years of treatability demonstrations with varied nuclear wastes).

b. Neutral pH is preferred for the waste repository and is a condition imposed on construction materials for the Yucca Mountain Project ${ }^{[28]}$.

c. Negligible open porosity preventing water intrusion; ceramic itself, once formed, does not accept water.

d. High sodium acceptance in the waste form avoids pre-treatment; low sodium leach rate means relative waste form stability.

e. High tolerance for waste constituents and conversion of most constituents to insoluble compounds minimizes the need for the addition of stabilizers. 


\section{I-8 Environment, Health, Safety and Quality (EHS\&Q) Processes}

\section{I-8.1 Environment, Health and Safety}

There were no incidents or ES\&H issues that occurred in the conduct of this project. Work activities were in compliance with all applicable federal and state laws, regulations and orders to protect worker and public health and safety, and with $\mathrm{CH} 2 \mathrm{M}$ HILL and ANL policies, manuals, and handbooks governing ES\&H practice.

\section{I-8.2 Quality Assurance (QA)}

The project team applied the CH2M HILL Nuclear Business Unit (NBU) Quality Assurance Program as an overarching umbrella program, with appropriate grading of controls, to the conduct of work for this project. This approach provided PNNL the ability to implement PNNL's applicable quality requirements that were specific to the scope while providing assurance that the work was performed in accordance with the requirements of 10 CFR Part 830 Subpart A and DOE 414.1. The NBU Quality Manual, NBU QA-01, was submitted to PNNL as a part of CH2M HILL's proposal for this project. In accordance with the contract, $\mathrm{CH} 2 \mathrm{M}$ HILL exercised responsibility for QA compliance by ANL, as subcontractor for the performance of laboratory work activities.

The Energy Technology Division (ETD) of ANL maintains a QA Plan, which is based on the Laboratory's Quality Assurance Program Plan and DOE Order 414.1 and which establishes the quality assurance policy and procedures that govern all ETD work activities. The specific quality assurance requirements and responsibilities that apply to the work elements associated with each ETD project are described in a project QA Appraisal Questionnaire or project QA Plan. Conformance with these project documents governs the validity of the results and conclusions of the work performed. ANL performed the chemical and analytical work for this project in accordance with its QA policy and procedures for adherence to high standards of quality in its research. 


\section{I-9 References}

1. Wagh, Arun S., Chemically Bonded Phosphate Ceramics, Elsevier pub. (2004), p. 300.

2. Innovative Technology Summary Report, Stabilization Using Phosphate Bonded Ceramics, DOE/EM-0486 (1999), p. 22.

3. Wagh, A. S., D. Maloney, G. H. Thomson, and A. Antink, Investigations in Ceramicrete stabilization of Hanford tank wastes, Proc. WM 2003 Conference, Tuscon, Feb. 23-27, 2003.

4. Sugama, T., and L. E. Kukacka, Characteristics of magnesium polyphosphate cements derived from ammonium polyphosphate solutions, Cement and Concrete Research, 13 (1983), pp. 499-506.

5. Wagh, A. S., R. Strain, S. Y. Jeong, D. Reed, T. Krause, and D. Singh, Stabilization of Rocky Flats Pu-Contaminated Ash within Chemically Bonded Phosphate Ceramics, J. Nuclear Materials, 265[3] March 1, 1999, pp. 295-307.

6. Wagh, A. S., S. Y. Jeong, D. Lohan, and A. Elizabeth, Chemically bonded phospho-silicate ceramics, U.S. Patent No. 6,518,212 issued February 11, 2003.

7. Wagh, Arun S., D. Singh, S,Y. Jeong, Chemically bonded phosphate ceramics for stabilization and solidification of mixed wastes, Hazardous and Radioactive Waste Treatment Technologies Handbook, Chapter 6-3, Chang H. Oh (ed.), CRC Press, Boca Raton (2001), pp. 1-18.

8. Singh D., V. Mandalika, S.Parulekar, and A. S. Wagh, Magnesium Potassium Phosphate Ceramic for 99Tc Immobilization, J. Nuclear Materials (2005).

9. Vance E. R., and D. K. Agrawal, X-ray studies of iodine sorption in some silver zeolites, J. Materials Science, 17 91982, 1889-1894.

10. *Chem Silver-Exchanged Molecular Sieves—Handling and Use, www.cchem.com/zeolite/techdata.html 
11. Clark, Boyd A., and R. Westberg, Cast stone technology for treatment and disposal of iodine-rich caustic waste demonstration-Final report RPP-26725 to CH2M HILL Hanford Group, Inc. (2005)—private communication with Boyd Clark and Larry Lockram of CH2M HILL Hanford Group.

12. Wagh, A. S., S. Y. Jeong, and D. Singh, High strength phosphate cement using industrial byproduct ashes, Proc. First International Conference on High Strength Concrete, Kona, HI, July 13-18, United Engineering Foundation, Inc. 1997, pp. 542-553.

13. ASTM C-39, Compressive Strength of Cylindrical Concrete Specimens, American Society of Testing Materials, 1979.

14. NRC Technical Position on Waste Form (Rev. 1), U.S. Nuclear Regulatory Commission, 1991.

15. Wescott, J., R. Nelson, A. Wagh, and D. Singh, Low-level and mixed radioactive waste in-drum solidification, Practice-Periodical of Hazardous, Toxic, and Radioactive Waste Management, (January 1998), pp. 4-7.

16. ASTM C-138, Standard Test Method for Density (Unit Weight), Yield, and Air Content (Gravimetric) of Concrete, American Society of Testing Materials, 2001.

17. ASTM B-533, Standard Test Method for Thermal Cycling of Electroplated Plastics, American Society of Testing Materials, 1979.

18. EPA Method 1311, Toxicity Characteristics Leaching Procedure, US Environmental Protection Agency.

19. ANSI/ANS 16.1, American National Standard Measurement of the Leachability of Solidified Low Level Radioactive Waste by Short Term Procedure, American Nuclear Society, 1986.

20. Preliminary Requirement 1: Stabilized Secondary Waste from Thermal LowActivity Waste Treatment, PNNL, March, 2004 (Attachment 1 to RFP No. 5529). 
21. ASTM C-1285, Standard Test Methods for Determining Chemical Durability of Nuclear, Hazardous, and Mixed Waste Glasses: The Product Consistency Test (PCT), American Society for Testing Materials, 1997.

22. Myasoedov, B., M. D. Maloney, A. S. Wagh, Chemically bonded phosphate ceramic alternative waste forms, International Conference on Alternative Nuclear Waste Forms; Girdwood, Alaska, January 18-23, 2004.

23. Plutonium Immobilization Product Specifications (PIPS), Report No. SRS PIP 01031, Rev. 0, 2001.

24. Marra and Marra, Shaw, Strachan, and Chamberlain, Environmental Issues and Waste Management Technologies in the Ceramic and Nuclear Industries, Ceramic Transactions, Vol. 119, 2000.

25. Vitrification and Product Testing of C-104 and AZ-102 Pretreated Sludge Mixed with Flowsheet Quantities of Secondary Waste, Report No. PNNL-13452; WTPRPT-006, Rev. 0, 2001.

26. W. L. Ebert et al., Corrosion Behavior of Environmental Assessment Glass in Product Consistency Tests of Extended Duration, Report No. ANL 98/27 and ANL 98/10, 1998.

27. Specification 2: Immobilized Low Activity Waste, WTP Contract No. DE-AC2701RV14136.

28. Dole, L. et al., Cost-Effective Cementitious Material Compatible with Yucca Mountain Repository Geochemistry, Report No. ORNL/TM-2004/296, Oak Ridge National Laboratory. 


\section{Part II. Facility Implementation Concepts for HSW and SBW}

Concepts have been developed based on the process steps and estimated quantities that were determined from the laboratory-scale demonstration work described in Part I of this report. The approach differed for the two concepts, which serves to bracket the deployment scenario in two ways. For the Hanford facility, a bottom-up approach was used, focused on first/capital costs (the quantities and consistencies are uncertain at this time). For the Idaho facility, a top-down, lifecycle approach was used, which includes operations and decommissioning/closure. The two were developed independently, yet both produced concepts that were consistent in cost and schedule within the level of detail of the worked performed for this project. Both concepts are conservative, particularly in facility sizing, since the estimated volumes of immobilized waste are overestimates.

Regarding the volumes of HSW and immobilized HSW, the Hanford facility is perhaps oversized by a considerable margin, since the consistency of the actual waste to be delivered to the facility is undecided at this point. For this project, it was assumed that the waste will be delivered with a water content of 90 percent or greater. Also, we envisioned partially dewatering the waste with a low temperature evaporator unit, thereby reducing the volume of waste to be immobilized by about 40 percent. During the treatability work in Part I, we actually reduced the volume by 60 percent and did not "push the envelope" at that. However, it could be that the HSW stream will be delivered as a filter cake at a 50 to 60 percent moisture content, in which case the evaporator unit may not be needed. Since the demonstration work did not yet optimize the load factor, we decided that a moderate amount of dewatering capability should be included in the concept. This can be expanded or eliminated depending on ultimate waste conditions and lifecycle, economics including packaging and disposal.

For the Idaho facility, the SBW consistency is better determined. Here the process concept includes a Cs separation step prior to dewatering. The higher activity (remote handled) and lower activity (contact handled) fractions would be immobilized in 
separate facilities, the former in a shielded cell. Our concept calls for evaporation to reduce the volume of the low activity fraction by 20 to 25 percent, whereas our treatability work showed that at least 40 percent was readily achievable without attempting to find the actual limit. Also for conservatism, we assumed a higher than necessary ratio of ceramic binder to waste.

\section{II-1 Process Description-Hanford Secondary Waste}

A conceptual diagram for immobilizing HSW in Ceramicrete is depicted in Figure 3. The following description of the HSW Ceramicrete treatment system (CTS) is based on processing the maximum volume of HSW; 800,000 liters at 2M sodium every 30 days $^{*}$ at 70 percent total operating efficiency (TOE). All vessels are sized to hold their contents at 85 percent capacity, providing an operating/safety margin. Table 21 summarizes the material balance for processing 800,000 liters of HSW every 30 days.

Figure 3-Conceptual Flow Diagram for Ceramicrete Immobilization of Hanford Secondary Waste

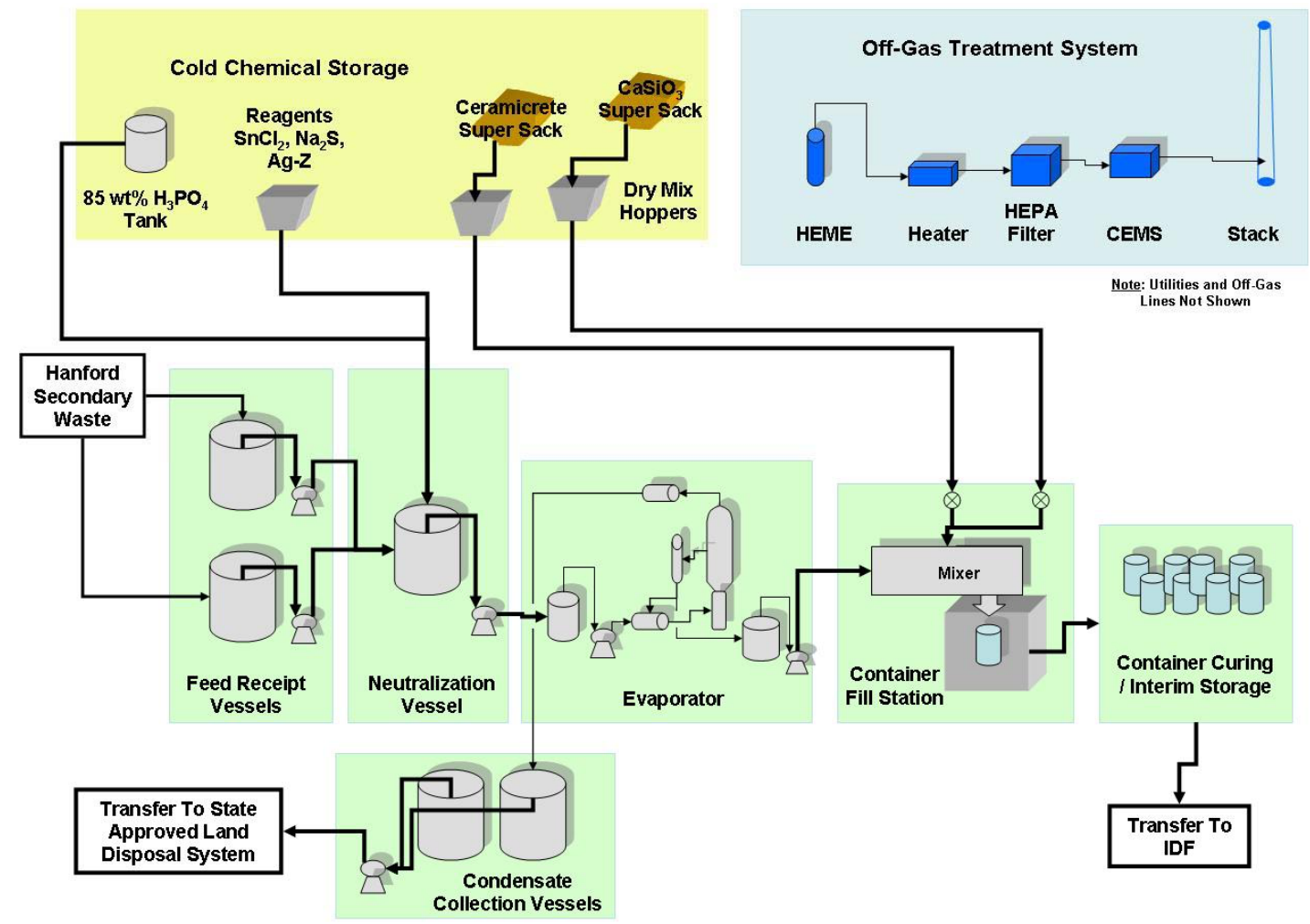

\footnotetext{
* The maximum HSW generation rate is identified in response to question 11 contained in Amendment No. 1 to RFP 5529 Low Temperature Waste Immobilization, dated 9/30/2004, J. A. Anderson, Pacific Northwest National Laboratory.
} 
Table 21-Ceramicrete Immobilization of Hanford Secondary Waste-Summary Material Balance ${ }^{1}$

\begin{tabular}{|c|c|c|c|c|c|c|c|c|c|c|}
\hline & $\begin{array}{c}\text { Stream } 1 \\
\text { HSW }\end{array}$ & $\begin{array}{c}\text { Stream } 2 \\
\text { H3PO } 4\end{array}$ & $\begin{array}{c}\text { Stream } 3 \\
\text { Acidified } \\
\text { HSW }\end{array}$ & $\begin{array}{c}\text { Stream } 4 \\
\text { Reagents2 }\end{array}$ & $\begin{array}{l}\text { Stream } 5 \\
\text { Feed to } \\
\text { Evaporator }\end{array}$ & $\begin{array}{c}\text { Stream } 6 \\
\text { Conc. } \\
\text { HSW }\end{array}$ & $\begin{array}{c}\text { Stream } 7 \\
\text { Process } \\
\text { Condensate }\end{array}$ & $\begin{array}{l}\text { Stream } 8 \\
\text { Calcium } \\
\text { Silicate }\end{array}$ & $\begin{array}{c}\text { Stream } 9 \\
\text { Ceramicrete } \\
\text { Pre-Mix3 }\end{array}$ & $\begin{array}{c}\text { Stream } 10 \\
\text { Ceramicrete } \\
\text { Immobilized } \\
\text { HSW }\end{array}$ \\
\hline Quantity & $800,000 \mathrm{~L}$ & $80,000 \mathrm{~L}$ & $880,000 \mathrm{~L}$ & $\begin{array}{l}5.87 \mathrm{E}+03 \mathrm{~kg} \\
\text { for each }\end{array}$ & $880,000 \mathrm{~L}$ & $521,066.7 \mathrm{~L}$ & 358,933.3 L & $1.60 \mathrm{E}+05 \mathrm{~kg}$ & $5.33 E+05 \mathrm{~kg}$ & $1.35 \mathrm{E}+06 \mathrm{~kg}$ \\
\hline $\begin{array}{l}\text { Density } \\
(\mathrm{gm} / \mathrm{ml})\end{array}$ & 1.08 & 1.69 & 1.14 & & 1.15 & 1.26 & 1.0 & 2.90 & & 2.06 \\
\hline Analyte & moles & moles & moles & moles & moles & moles & moles & moles & moles & moles \\
\hline $\mathrm{Ag}$ & & & & $2.29 E+04$ & $2.29 E+04$ & $2.29 E+04$ & & & & $2.29 E+04$ \\
\hline $\mathrm{Cl}^{-}$ & & & & $5.62 E+04$ & $5.62 E+04$ & $5.62 E+04$ & & & & $5.62 E+04$ \\
\hline $\mathrm{F}^{-}$ & & & & $6.84 \mathrm{E}+04$ & $6.84 \mathrm{E}+04$ & $6.84 \mathrm{E}+04$ & & & & $6.84 \mathrm{E}+04$ \\
\hline $\mathrm{H}^{+}$ & & $3.52 E+06$ & $3.43 E+06$ & & $3.43 E+06$ & $3.43 E+06$ & & & & $3.43 E+06$ \\
\hline $\mathrm{Na}^{+}$ & $1.60 \mathrm{E}+06$ & & $1.60 \mathrm{E}+06$ & $1.37 E+05$ & $1.74 \mathrm{E}+06$ & $1.74 \mathrm{E}+06$ & & & & $1.74 \mathrm{E}+06$ \\
\hline $\mathrm{PO}_{4}^{-3}$ & & 1.17E+06 & 1.17E+06 & & $1.17 \mathrm{E}+06$ & $1.17 \mathrm{E}+06$ & & & & $1.17 \mathrm{E}+06$ \\
\hline Sn & & & & $2.81 E+04$ & $2.81 E+04$ & $2.81 E+04$ & & & & $2.81 E+04$ \\
\hline $\mathrm{MgO}$ & & & & & & & & & $6.62 \mathrm{E}+06$ & $6.62 E+06$ \\
\hline $\mathrm{KH}_{2} \mathrm{PO}_{4}$ & & & & & & & & & $1.96 \mathrm{E}+06$ & $1.96 \mathrm{E}+06$ \\
\hline $\mathrm{CaSiO}_{3}$ & & & & & & & & $1.38 \mathrm{E}+03$ & & $1.38 \mathrm{E}+03$ \\
\hline
\end{tabular}

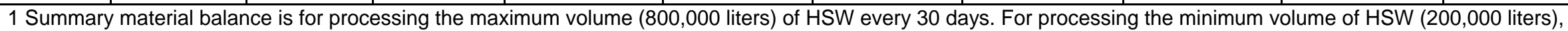
divide all values by four.

2 Mass is the same for each of the three reagents (sodium sulfide, stannous chloride, and bismuth oxide) that are added.

3 Ceramicrete pre-mix is a 50:50 mixture of magnesium oxide and potassium monophosphate 
The HSW is assumed to have been adequately characterized by the generator facility before transfer to the CTS.

\section{II-1.1 Waste Receipt}

The HSW is assumed to be received as a liquid waste stream* into one of two, $\sim 4,000$-gallon capacity vessels at the CTS. Each of the HSW feed receipt vessels is sized to receive the maximum volume of HSW generated in an 8-hour period. One of the feed receipt vessels is used to receive HSW while the second vessel is transferring HSW to the neutralization vessel.

\section{II-1.2 Partial Neutralization}

Approximately 1,680 gallons of HSW are transferred every 4 hours from the feed receipt vessels to the neutralization vessel (capacity is 2,200 gallons).

Approximately 0.1 liters of $85 \mathrm{wt} \%$ phosphoric acid are added per liter of HSW ( $\sim 168$ gallons per batch) to adjust the mixture to $\mathrm{pH} \sim 5$. The addition of phosphoric acid also serves to convert most of the lower valence state metal cations to insoluble phosphate compounds and convert iodate $\left(\mathrm{IO}_{3}{ }^{-}\right)$to iodide $\left(\mathrm{I}^{-}\right)$at this slightly acidic condition.

\section{II-1.3 Reagents Addition}

Approximately 23.4 grams of stabilizing reagents are added per liter of HSW to the neutralization vessel while the acidified HSW is being mixed. These reagents, stannous chloride $\left(\mathrm{SnCl}_{2}\right)$ and silver zeolite $\left(\mathrm{Ag}_{2} \mathrm{O}-\mathrm{Al}_{2} \mathrm{O}_{3}-\mathrm{SiO}_{2}\right.$, or $\mathrm{Ag}-\mathrm{Z}$ in this report), are added as dry materials and quickly dissolve in the acidic $\mathrm{HSW}$. The $\mathrm{SnCl}_{2}$ reduces pertechnetate $\left(\mathrm{Tc}^{(\mathrm{VII})} \mathrm{O}_{4}{ }^{-2}\right)$ to technetium pentoxide $\left(\mathrm{Tc}_{2}{ }^{(\mathrm{V})} \mathrm{O}_{5}\right)$ or tetroxide $\left(\mathrm{Tc}^{(\mathrm{IV})} \mathrm{O}_{2}\right)$. The $\mathrm{Ag}-\mathrm{Z}$ appears to have a cage structure that captures iodine and reacts to insoluble Agl.

Approximately $148 \mathrm{kgs}$ of reagent are added per batch to the neutralization vessel.

\footnotetext{
* The HSW was identified as an aqueous liquid waste stream in response to question 9 contained in Amendment No. 1 to RFP 5529 Low Temperature Waste Immobilization, dated 9/30/2004, J. A. Anderson, Pacific Northwest National Laboratory. The waste simulant received for the Part I studies conformed to this specification.
} 


\section{II-1.4 Partial Dewatering by Evaporation}

The 1,845 -gallon batch of acidified HSW is transferred to a vacuum-operated, forced circulation evaporator where excess water is removed to minimize the volume of the immobilized Ceramicrete waste form. The volume of the acidified HSW solution is reduced by approximately 40 percent during evaporation, yielding $\sim 1,090$ gallons of concentrated HSW. This is conservative in that a greater volume reduction was shown to be achievable with Ceramicrete and, if HSW is delivered as a filter cake, the evaporator may not be needed.

The evaporator process condensate ( 755 gallons per batch) is collected into one of two condensate collection vessels. Each condensate collection vessel (capacity 5,300 gallons) can store the total condensate generated in 24 hours; about 4,515 gallons. Two condensate collection vessels are employed to allow one vessel to be receiving condensate while the other vessel is being sampled and discharged. The condensate is discharged via an underground pipeline to the State Approved Land Disposal System (SALDS) currently receiving liquid effluent from the 200-East Area Effluent Treatment Facility (ETF).

A forced circulation evaporator is used to concentrate the acidified HSW to minimize fouling of the heat exchanger from solids. The evaporator operates under a vacuum to allow low temperature $\left(50^{\circ}\right.$ to $\left.65^{\circ} \mathrm{C}\right)$ evaporation of the acidified HSW. The evaporator subsystem is sized to process $29.1 \mathrm{lpm}(\sim 7.7 \mathrm{gpm})$ of acidified HSW and consists of a high-volume pump, heat exchanger, evaporator vessel, condenser, 500-gallon capacity evaporator feed vessel, and 500-gallon capacity concentrated HSW receipt vessel.

\section{II-1.5 Ceramicrete Immobilization}

Following concentration, the $\sim 1,090$-gallon batch of concentrated HSW is transferred to an immobilization subsystem where calcium silicate or fly ash and Ceramicrete formers (i.e., 25:75 weight ratio pre-mixed magnesium oxide and monopotassium phosphate) are mixed with the waste and discharged to disposal containers. A continuous, ribbon-type mixer is used to process the concentrated HSW and these dry reagents. The ribbon-type mixer is sized for producing $\sim 2.04 \mathrm{~m}^{3}$ 
( 4.2 MT) Ceramicrete batches. Approximately $1,270 \mathrm{kgs}$ of calcium silicate and 4,230 kgs of Ceramicrete formers are added per batch of concentrated HSW for immobilization, producing $\sim 10,710 \mathrm{kgs}$ of Ceramicrete. Approximately 1,350 MT of Ceramicrete-immobilized HSW is produced every 30 days from the maximum HSW generation rate of 800,000 liters per 30 days.

Based on the HSW radionuclide content and our flowsheet calculations, the ${ }^{129}$ I and ${ }^{99} \mathrm{Tc}$ concentrations will be a maximum of $6.6 \mathrm{E}-04 \mathrm{Ci} / \mathrm{m}^{3}$ and $4.15 \mathrm{E}-02 \mathrm{Ci} / \mathrm{m}^{3}$ in the Ceramicrete-immobilized HSW. The ${ }^{129} \mathrm{I}$ and ${ }^{99} \mathrm{Tc}$ concentrations in the Ceramicrete-immobilized HSW are approximately 0.9 percent and 1.4 percent of their respective limits listed in 10 CFR $\S 61.55$, Table 1. Therefore, the Ceramicreteimmobilized HSW will be less than the Class $\mathrm{C}$ limits for these radionuclides. The concentrations of additional radionuclides (e.g., ${ }^{137} \mathrm{Cs}$ and ${ }^{60} \mathrm{Co}$ ) present in the HSW are not specified in RFP No. 5529. These additional radionuclides need to be quantified in order to fully demonstrate compliance with 10 CFR §61.55 Class C limits.

\section{/I-1.6 Container Selection}

The production rate of Ceramicrete-immobilized HSW is approximately 2,680 kgs per hour at 70 percent TOE, or approximately $1,875 \mathrm{kgs}$ per hour at 100 percent TOE; i.e., a two-shift or three-shift operation to meet the specified HSW generation rate (Part I ${ }^{[1]}$ ). The density of the Ceramicrete waste form is approximately 2.06-MT/ $\mathrm{m}^{3}$. Table 22 lists the number of different types of containers containing the Ceramicrete-immobilized HSW that would be produced per day. It is evident from Table 22 that 55-gallon drums or 85-gallon drums cannot be used for disposal of the Ceramicrete-immobilized HSW, given the excessive number of containers generated per day. A larger container, such as a $50-\mathrm{yd}^{3}$ metal box, would greatly reduce container handling logistics, but could be problematic during filling and Ceramicrete curing. Container requirements need to be determined, but for purposes of this concept report, an intermediate container similar in size to the Waste Treatment and Immobilization Plant (WTP) immobilized low-activity waste (ILAW) container is 
assumed for disposal of the Ceramicrete-immobilized HSW. Curing of the Ceramicrete should not be a problem in the WTP ILAW container.

Table 22-Disposal Container Evaluation

\begin{tabular}{|l|l|}
\hline \multicolumn{1}{|c|}{ Container Type } & \multicolumn{1}{c|}{ Number per Day } \\
\hline 55-gallon metal drum & 166.5 \\
\hline 85-gallon metal drum & 107.7 \\
\hline 2.26-m3 metal container & 15.3 \\
\hline 50-yd3 metal box & 0.9 \\
\hline
\end{tabular}

${ }^{1}$ Assumes 90 percent fill and 70 percent TOE.

Approximately 15 containers per day (at 70 percent TOE) will be produced, each containing $2.04 \mathrm{~m}^{3}$ (4.2 MT at 90 percent fill) of Ceramicrete-immobilized HSW. A uniquely labeled container will be positioned at the container filling station and loaded with Ceramicrete-immobilized HSW. The filled containers will be sealed, surveyed (external contamination removed if necessary), and equipped with a Nucfil $013^{\mathrm{TM}}$ filter (or equivalent) and a hydrogen recombination catalyst to mitigate hydrogen accumulation if necessary. Tests have shown very low hydrogen generation, perhaps due to the abundance of $\mathrm{MgO}$, a known hydrogen getter, in Ceramicrete, and the dense matrix allowing for recombination.

\section{II-1.7 Container Interim Storage}

The Ceramicrete-immobilized HSW will cure within 24 hours of pouring into the 2.04- $\mathrm{m}^{3}$ container. While the previous day's production is curing for 24 hours, the current day's production of containers will be accumulated at the CTS. Therefore, interim storage is provided for 2 days of production, and 30 containers.

\section{II-1.8 Deployment Concept and Integration with Other Hanford Facilities}

\section{II-1.8.1 Deployment Concept}

Major equipment required for the Ceramicrete immobilization of the Hanford secondary waste is identified in Table 23 and is based on the process description provided above. A preliminary facility concept drawing has been prepared depicting the equipment arrangement. The preliminary facility concept, Figure 4 , includes an industrial-type structure housing the process equipment (50 feet by 25 feet), container interim storage pad ( 40 feet by 40 feet), an office / control room structure 
(20 feet by 50 feet), and locations for chemical reagent storage. The industrial-type structure housing the process equipment is warranted based on the very low radionuclide concentrations present in the HSW, and is similar to the 200-East Area ETF structure.

Table 23-Preliminary Major Equipment List for Ceramicrete Immobilization of HSW

\begin{tabular}{|c|c|c|c|}
\hline Equipment 1,2 & Quantity & $\begin{array}{l}\text { Size, Feet } \\
(H \times D)\end{array}$ & $\begin{array}{c}\text { Maximum } \\
\text { Capacity (gal.) }\end{array}$ \\
\hline $\begin{array}{l}\text { HSW Feed Receipt Vessel (Tk-Fr-01/02) } \\
\text { 304-L Stainless Steel } \\
\text { Transfer Pump }\end{array}$ & $\begin{array}{l}2 \\
2\end{array}$ & $\begin{array}{l}9 \times 9 \\
100 \mathrm{gpm}\end{array}$ & 4,000 \\
\hline $\begin{array}{l}\text { Phosphoric Acid Chemical } \\
\text { Storage Tank (Tk-Pa-01) } \\
\text { Carbon Steel } \\
\text { Transfer Pump }\end{array}$ & $\begin{array}{l}1 \\
1\end{array}$ & $\begin{array}{l}3.3 \times 3.3 \\
0 \text { To } 5 \mathrm{gpm}\end{array}$ & 200 \\
\hline $\begin{array}{l}\text { HSW Acidification Vessel (Tk-As-01) } \\
\text { 304-L Stainless Steel } \\
\text { Transfer Pump }\end{array}$ & $\begin{array}{l}1 \\
1\end{array}$ & $\begin{array}{l}7.2 \times 7.2 \\
100 \mathrm{gpm}\end{array}$ & 2,200 \\
\hline $\begin{array}{l}\text { Dry Stabilizing Reagent Hooper (BN-01/02/03) } \\
\text { Carbon Steel } \\
\text { Pneumatic Transfer }\end{array}$ & $\begin{array}{l}3 \\
3\end{array}$ & $\begin{array}{l}3.7 \times 3.7 \\
0.5 \text { To } 2 \mathrm{~kg} / \text { minute }\end{array}$ & 100 \\
\hline $\begin{array}{l}\text { Evaporator Feed Vessel (TK-FE-01) } \\
\text { 304-L Stainless Steel } \\
\text { Transfer Pump }\end{array}$ & $\begin{array}{l}1 \\
1 \\
\end{array}$ & $\begin{array}{l}4.4 \times 4.4 \\
0 \text { To } 10 \mathrm{gpm}\end{array}$ & 500 \\
\hline $\begin{array}{l}\text { Evaporator Concentrate Vessel (TK-CE-01) } \\
\text { 304-L Stainless steel } \\
\text { Transfer pump }\end{array}$ & $\begin{array}{l}1 \\
1 \\
\end{array}$ & $\begin{array}{l}4.4 \times 4.4 \\
0 \text { to } 10 \mathrm{gpm}\end{array}$ & 500 \\
\hline $\begin{array}{l}\text { Evaporator - 304-L stainless steel } \\
\text { Re-boiler (E-01) } \\
\text { Vapor-liquid separator vessel (EV-01) } \\
\text { Recirculation pump (PE-01) } \\
\text { Concentrate pump (PE-02) } \\
\text { Primary condenser (E-02) } \\
\text { Secondary condenser (E-03) }\end{array}$ & $\begin{array}{l}1 \\
1 \\
1 \\
1 \\
1 \\
1 \\
\end{array}$ & $\begin{array}{l}\text { TBD Btu/hr } \\
\text { TBD } \\
\sim 10,000 \mathrm{gpm} \\
0 \text { to } 10 \mathrm{gpm} \\
\text { TBD Btu/hr } \\
\text { TBD Btu/hr } \\
\end{array}$ & $\begin{array}{l}\text { N/A } \\
1,000 \\
\text { N/A } \\
\text { N/A } \\
\text { N/A }\end{array}$ \\
\hline $\begin{array}{l}\text { Process Condensate Vessel (TK-PC-01/02) } \\
\text { 304-L Stainless steel } \\
\text { Transfer pump }\end{array}$ & $\begin{array}{l}2 \\
2\end{array}$ & $\begin{array}{l}9.7 \times 9.7 \\
100 \mathrm{gpm}\end{array}$ & 5,300 \\
\hline $\begin{array}{l}\text { Calcium Silicate Hopper (BN-04) } \\
\text { Carbon steel } \\
\text { Pneumatic transfer }\end{array}$ & $\begin{array}{l}1 \\
1\end{array}$ & $\begin{array}{l}5.6 \times 5.6 \\
0 \text { to } 6 \mathrm{~kg} / \text { minute }\end{array}$ & 1,000 \\
\hline $\begin{array}{l}\text { Ceramicrete Pre-Mix Hopper (BN-05) } \\
\text { Carbon steel } \\
\text { Pneumatic transfer }\end{array}$ & $\begin{array}{l}1 \\
1\end{array}$ & $\begin{array}{l}8.3 \times 8.3 \\
0 \text { to } 20 \mathrm{~kg} / \text { minute }\end{array}$ & 3,300 \\
\hline $\begin{array}{l}\text { Ceramicrete Ribbon-type Mixer (ME-01) } \\
\text { Carbon steel }\end{array}$ & 1 & $2.04 \mathrm{m3} / \mathrm{batch}$ & 540 \\
\hline
\end{tabular}




\begin{tabular}{|l|l|l|l|}
\hline \multicolumn{1}{|c|}{ Equipment 1,2 } & Quantity & \multicolumn{1}{|c|}{$\begin{array}{c}\text { Size, Feet } \\
\text { (H x D) }\end{array}$} & $\begin{array}{c}\text { Maximum } \\
\text { Capacity (gal.) }\end{array}$ \\
\hline $\begin{array}{l}\text { Container storage area with 10MT overhead } \\
\text { crane }\end{array}$ & 1 & $\begin{array}{l}40-\mathrm{ft} \times 40-\mathrm{ft} \times 25-\mathrm{ft} \\
(\mathrm{W} \times \mathrm{L} \times \mathrm{H})\end{array}$ & 36 containers \\
\hline Underground Pipeline & N/A & $4,500-\mathrm{ft}$ & N/A \\
\hline Dust Bag House & 1 & TBD & TBD \\
\hline Process Off-Gas Treatment System & 1 & N/A & N/A \\
\hline Facility Off-Gas Treatment System & 1 & N/A & N/A \\
\hline Distributive Control System (DCS) & 1 & N/A & N/A \\
\hline Office / Control Room area & 1 & $\begin{array}{l}20 \times 50 \times 40 \\
(\mathrm{~W} \times \mathrm{L} \times \mathrm{H})\end{array}$ & $\begin{array}{l}1,000 \mathrm{ft} 2 \\
40,000 \mathrm{ft} 3\end{array}$ \\
\hline
\end{tabular}

1 All vessels will be equipped with pressure, liquid level, specific gravity, low-level indicator, and high-level indicator instrumentation.

2 Instrumentation and utilities not listed.

Figure 4-Preliminary Facility Arrangement Diagram for Ceramicrete Immobilization of Hanford Secondary Waste

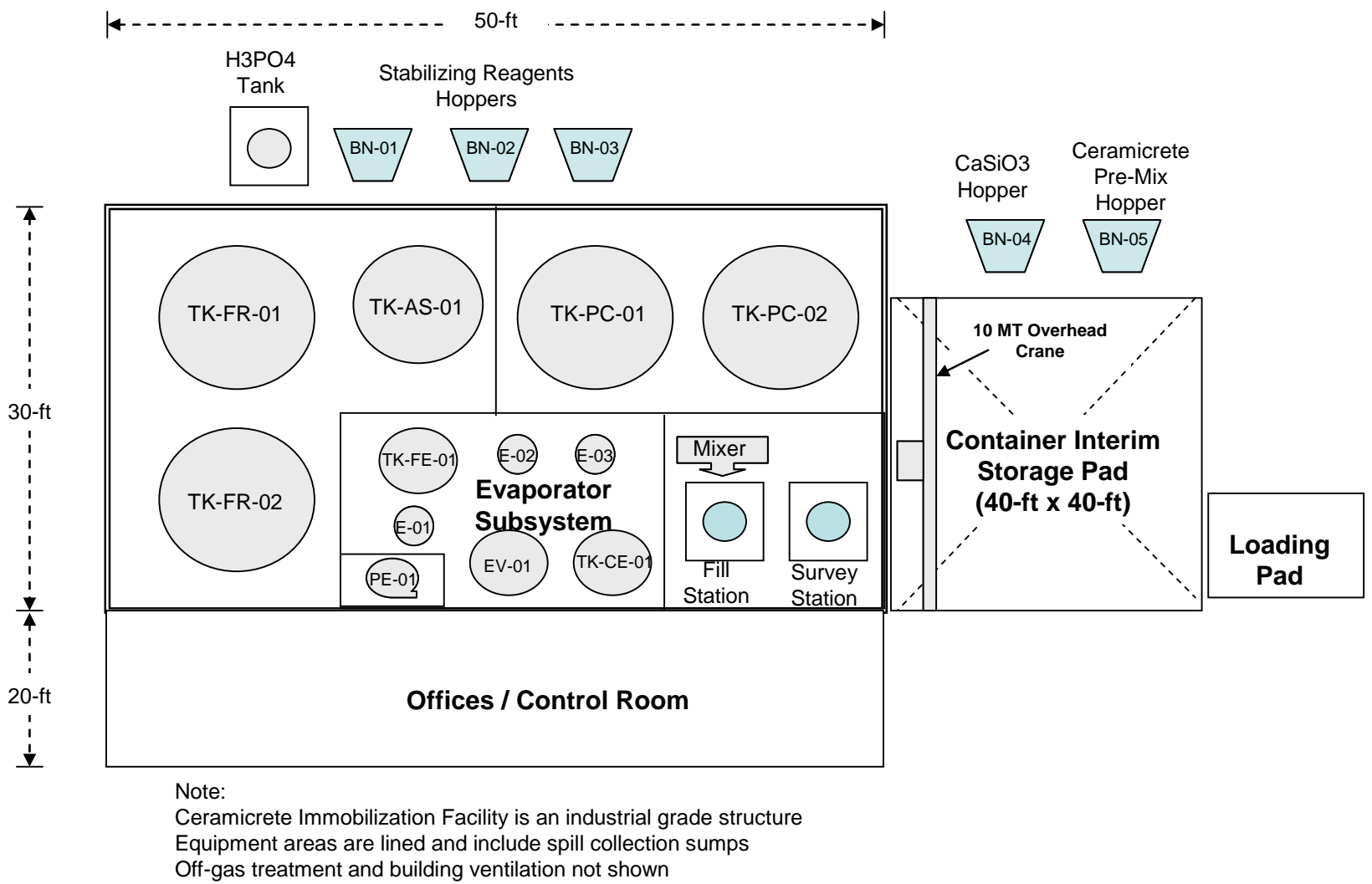




\section{II-1.8.2 Integration with Other Hanford Facilities}

The Ceramicrete Treatment Facility will need to process secondary waste generated from the Hanford waste vitrification systems. These waste vitrification systems include the WTP as well as any Supplemental LAW Treatment Facility. The WTP is located in the southwest quadrant of the 200-East Area at the Hanford site. The WTP design currently includes transferring the secondary waste from the vitrification systems (i.e., aqueous liquid caustic scrubber solution) to the ETF via an underground pipeline. A specific location for the Supplemental LAW Treatment Facility has not been selected, but location options include the WTP site (for the Second LAW Vitrification Facility) and the 200-West Area.

The Ceramicrete Treatment Facility will also be located in the 200-East Area, near the 200-East ETF to take advantage of available land and proximity to the ETF and the SALDS. Figure 5 depicts the proposed location of the Ceramicrete Treatment Facility. This location will enable liquid secondary wastes generated at the WTP and Supplemental LAW Treatment Facility to be centrally collected for treatment in the Ceramicrete Treatment Facility. This avoids the more costly alternative of having separate secondary waste solidification processes at both the WTP and the Supplemental LAW Treatment Facility. Process condensate, generated from the evaporator subsystem located in the Ceramicrete Treatment Facility, can also be easily routed via new underground pipelines to either the ETF or the SALDS.

Electrical services for the Ceramicrete Treatment Facility will be provided from existing services. A packed steam unit for the evaporator subsystem will be locally provided. Requirements for services will be defined in more detail during subsequent phases of this project.

If the HSW is a solid/filter cake produced at the ETF, then the immobilization could be conducted in the third melter cell within the WTP LAW Vitrification Facility. However, assuming the HSW is an aqueous liquid waste stream generated at the rate specified in the RFP for this project, the size of the required process equipment is such that the third melter cell within the WTP LAW Vitrification Facility would be too small to house the CTS. 
Figure 5-Proposed Location of Ceramicrete Treatment Facility

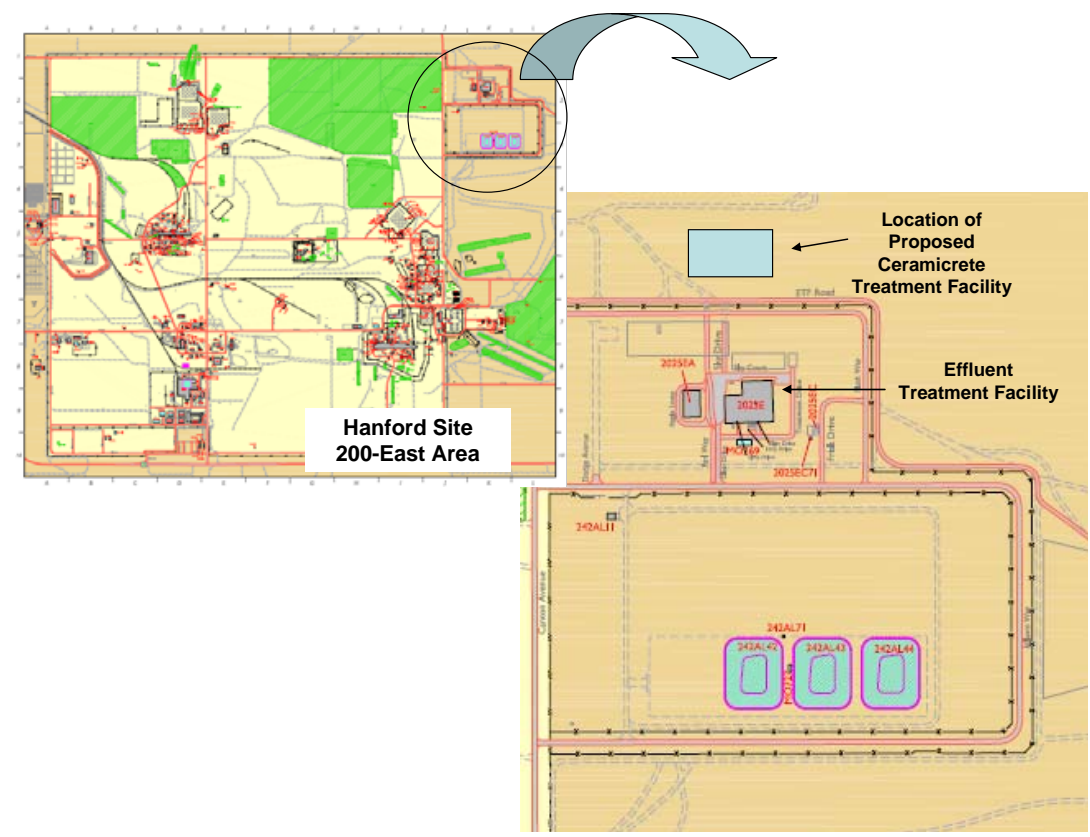

\section{II.1.9 Performance Requirements}

A preliminary compliance matrix (see Table 24) has been developed to demonstrate our approach for meeting performance requirements listed in the RFP and Preliminary Requirement 1: Stabilized Secondary Waste from Thermal LowActivity Waste Treatment. This matrix will be expanded into a separate Waste Form Compliance Plan during the next phase of this project. A similar Waste Form Compliance Plan will be developed for the Idaho SBW during the next phase of this project.

Part I of this report provides results from the treatability demonstration testing that indicates compliance with the key performance requirements for both HSW and SBW.

Table 24-Preliminary Requirements Compliance Matrix for Hanford Secondary Waste Immobilization

\begin{tabular}{|l|l|l|}
\hline Characteristic & \multicolumn{1}{|c|}{ Requirement } & \multicolumn{1}{c|}{ Approach to Meet Requirement } \\
\hline Waste Feed Properties from RFP No. 5529 Statement of Work \\
\hline Form & $\begin{array}{l}\text { Liquid (Based on response to } \\
\text { question 9 listed in Amendment No. } \\
1 \text { to RFP 5529 Low Temperature } \\
\text { Waste Immobilization, dated } \\
\text { September 30, 2004) }\end{array}$ & $\begin{array}{l}\text { Design includes liquid feed receipt and } \\
\text { handling features. }\end{array}$ \\
\hline
\end{tabular}




\begin{tabular}{|c|c|c|}
\hline Characteristic & Requirement & Approach to Meet Requirement \\
\hline Volume & $\begin{array}{l}200,000 \text { to } 800,000 \text { liters every } \\
30 \text { days } \\
\text { (Based on response to question } 11 \\
\text { listed in Amendment No. } 1 \text { to } \\
\text { RFP 5529, Low Temperature Waste } \\
\text { Immobilization, dated September 30, } \\
2004 \text { ) }\end{array}$ & $\begin{array}{l}\text { Design sized to processes } 800,000 \\
\text { liters every 30-days; } 26.5 \mathrm{lpm} \text { at } 70 \\
\text { percent TOE. }\end{array}$ \\
\hline \multicolumn{3}{|c|}{$\begin{array}{l}\text { Preliminary Requirement 1: Stabilized Secondary Waste (SSW) from Thermal LAW } \\
\text { Treatment }\end{array}$} \\
\hline $\begin{array}{l}\text { 1.2.2.2 and } \\
1.2 .2 .3 \\
\text { Package Size } \\
\text { and } \\
\text { Configuration }\end{array}$ & $\begin{array}{l}\text { Meet Hanford Site Solid Waste } \\
\text { Acceptance Criteria (HNF-EP-0063, } \\
\text { rev. 7, Chapters } 2 \text { and 4) }\end{array}$ & $\begin{array}{l}\text { Design uses WTP type ILAW canister; } \\
\text { circular cylinder, } 2.3 \mathrm{~m} \text { high and } \\
1.22 \mathrm{~m} \text { diameter. Detailed design of } \\
\text { container will be used to document } \\
\text { container acceptability. }\end{array}$ \\
\hline 1.2.2.4 Mass & $<85 \mathrm{MT}$ & $\begin{array}{l}\text { Ceramicrete SSW + container } \\
\text { maximum mass is } \sim 5 \mathrm{MT} \text {. Container } \\
\text { weight will be measured and } \\
\text { documented to demonstrate } \\
\text { compliance. }\end{array}$ \\
\hline $\begin{array}{l}\text { 1.2.2.5 Closure } \\
\text { and Sealing }\end{array}$ & $\begin{array}{l}\text { Equip container with a Nucfil } 013 \\
\text { filter (or equivalent) and a hydrogen } \\
\text { recombination catalyst to mitigate } \\
\text { hydrogen accumulation }\end{array}$ & $\begin{array}{l}\text { Container design will incorporate these } \\
\text { features. Documentation will be } \\
\text { provided that filter and catalyst are } \\
\text { installed at time of container transfer to } \\
\text { DOE. }\end{array}$ \\
\hline 1.2.2.6 Labeling & $\begin{array}{l}\text { Label each package in accordance } \\
\text { with HNF-EP-0063, rev. } 7, \\
\text { Appendix C }\end{array}$ & $\begin{array}{l}\text { Design incorporates uniquely labeled } \\
\text { containers meeting requirements. }\end{array}$ \\
\hline $\begin{array}{l}\text { 1.2.2.7 Void } \\
\text { Space }\end{array}$ & $<10$ percent void space & $\begin{array}{l}\text { Containers will be filled a minimum of } \\
90 \text { percent. Container weight will be } \\
\text { measured and documented to } \\
\text { demonstrate compliance. }\end{array}$ \\
\hline $\begin{array}{l}\text { 1.2.2.8 } \\
\text { Radionuclide } \\
\text { Concentration } \\
\text { Limits }\end{array}$ & $\begin{array}{l}\text { Less than Class C; less than waste } \\
\text { category } 3 \text { as defined in HNF-EP- } \\
0063 \text {, rev. } 7 \text {, Appendix A }\end{array}$ & $\begin{array}{l}\text { Radionuclide concentrations in HSW } \\
\text { feed to treatment process will be } \\
\text { documented and calculations } \\
\text { performed to demonstrate compliance } \\
\text { with this requirement. } \\
\text { Additional information on radionuclide } \\
\text { content of HSW is required to } \\
\text { demonstrate compliance. }\end{array}$ \\
\hline $\begin{array}{l}1.2 .2 .9 \\
\text { Radionuclide } \\
\text { Composition } \\
\text { Documentation }\end{array}$ & $\begin{array}{l}\text { Document radionuclide composition } \\
\text { per NUREG/BR-0204 and } 49 \text { CFR } \\
172.101 ; \text { index to } 12 / 31 / 2002\end{array}$ & $\begin{array}{l}\text { Documentation will be prepared during } \\
\text { operating phase. }\end{array}$ \\
\hline
\end{tabular}




\begin{tabular}{|c|c|c|}
\hline Characteristic & Requirement & Approach to Meet Requirement \\
\hline \multicolumn{3}{|c|}{$\begin{array}{l}\text { Preliminary Requirement 1: Stabilized Secondary Waste (SSW) from Thermal LAW } \\
\text { Treatment }\end{array}$} \\
\hline $\begin{array}{l}\text { 1.2.2.10 } \\
\text { Surface Dose } \\
\text { Rate Limit }\end{array}$ & $\begin{array}{l}<500-\mathrm{mrem} / \mathrm{hr} \text { at any point on } \\
\text { external surface }\end{array}$ & $\begin{array}{l}\text { Design includes container survey } \\
\text { station. Surface dose rate will be } \\
\text { measured and documented. Additional } \\
\text { information on radionuclide content of } \\
\text { HSW is required to demonstrate } \\
\text { compliance. }\end{array}$ \\
\hline $\begin{array}{l}\text { 1.2.2.11 } \\
\text { Surface } \\
\text { Contamination } \\
\text { Limit }\end{array}$ & $\begin{array}{l}\text { Removable contamination }<367 \\
\mathrm{~Bq} / \mathrm{m}^{2} \text { for alpha; }<3670 \mathrm{~Bq} / \mathrm{m}^{2} \text { for } \\
\text { beta-gamma }\end{array}$ & $\begin{array}{l}\text { Design includes container } \\
\text { survey/decontamination area. } \\
\text { Container surface contamination will } \\
\text { be measured and documented. }\end{array}$ \\
\hline $\begin{array}{l}1.2 .2 .12 \\
\text { External } \\
\text { Temperature }\end{array}$ & $\begin{array}{l}\text { Container surface temperature }<50^{\circ} \\
C \text { when returned to DOE }\end{array}$ & $\begin{array}{l}\text { Design includes container curing and } \\
\text { cooling area; container }<50^{\circ} \mathrm{C} \text { at time } \\
\text { of shipment. Thermal analysis or other } \\
\text { means will be prepared to document } \\
\text { compliance. }\end{array}$ \\
\hline $\begin{array}{l}\text { 1.2.2.13 Free } \\
\text { Liquids }\end{array}$ & No detectable free liquids & $\begin{array}{l}\text { Ceramicrete mixture incorporates } \\
\text { water present in waste; formulation } \\
\text { ensures no free liquid in waste } \\
\text { container. Information will be } \\
\text { documented. }\end{array}$ \\
\hline $\begin{array}{l}1.2 .2 .14 \\
\text { Pyrophoricity or } \\
\text { Explosivity }\end{array}$ & $\begin{array}{l}\text { Non-pyrophoric; non-explosive waste } \\
\text { form }\end{array}$ & $\begin{array}{l}\text { Ceramicrete has been previously } \\
\text { tested and demonstrated to meet } \\
\text { pyrophoricity and ignitability } \\
\text { requirements. (Part I }{ }^{[1,5]} \text { ). HSW and } \\
\text { SBW waste forms contain no explosive } \\
\text { compounds. Information will be } \\
\text { documented. }\end{array}$ \\
\hline $\begin{array}{l}1.2 .2 .15 \\
\text { Explosive or } \\
\text { Toxic Gases }\end{array}$ & $\begin{array}{l}\text { Not capable of generating explosive } \\
\text { or toxic gases, vapors, or fumes } \\
\text { harmful to persons }\end{array}$ & $\begin{array}{l}\text { Ceramicrete consists of mineral phase } \\
\text { refractory materials stable to }>1300^{\circ} \mathrm{C} \\
\left(\text { Part I I }{ }^{[1]} \text {. Testing for toxic emissions }\right. \\
\text { can be performed and documented. }\end{array}$ \\
\hline $\begin{array}{l}\text { 1.2.2.16 } \\
\text { Dangerous } \\
\text { Waste } \\
\text { Limitations }\end{array}$ & $\begin{array}{l}\text { Meet land disposal regulations in } \\
\text { WAC } 173-303 \text { and RCRA LDR in } 40 \\
\text { CFR268. Full analysis of constituents } \\
\text { and TCLP testing }\end{array}$ & $\begin{array}{l}\text { Representative waste samples will be } \\
\text { analyzed and tested to demonstrate } \\
\text { compliance. }\end{array}$ \\
\hline $\begin{array}{l}1.2 .2 .17 \\
\text { Compressive } \\
\text { Strength }\end{array}$ & $\begin{array}{l}\text { Mean compressive strength of the } \\
\text { waste form shall be at least 3.45E6 } \\
\text { Pa (ASTM C39/C39M-99 or } \\
\text { equivalent method) }\end{array}$ & $\begin{array}{l}\text { Representative non-radioactive waste } \\
\text { form samples will be tested to } \\
\text { demonstrate compliance. }\end{array}$ \\
\hline $\begin{array}{l}1.2 .2 .18 \\
\text { Compression } \\
\text { Testing }\end{array}$ & $\begin{array}{l}\text { Each fully loaded package shall be } \\
\text { able to withstand a compression load } \\
\text { of } 50,000 \mathrm{~kg}\end{array}$ & $\begin{array}{l}\text { Analysis and full-scale testing of } \\
\text { package loaded with Ceramicrete } \\
\text { stabilized simulant will be conducted } \\
\text { per } 49 \text { CFR173.465(d). }\end{array}$ \\
\hline
\end{tabular}




\begin{tabular}{|c|c|c|}
\hline Characteristic & Requirement & Approach to Meet Requirement \\
\hline \multicolumn{3}{|c|}{$\begin{array}{l}\text { Preliminary Requirement 1: Stabilized Secondary Waste (SSW) from Thermal LAW } \\
\text { Treatment }\end{array}$} \\
\hline $\begin{array}{l}\text { 1.2.2.19 } \\
\text { Container } \\
\text { Material } \\
\text { Degradation }\end{array}$ & $\begin{array}{l}\text { Container resistant to degradation by } \\
\text { microbial action, moisture, radiation } \\
\text { effects, or chemical reactions with } \\
\text { the container contents under } \\
\text { expected storage conditions; 50-year } \\
\text { container life }\end{array}$ & $\begin{array}{l}\text { Analysis of container will be performed } \\
\text { to demonstrate compliance. }\end{array}$ \\
\hline $\begin{array}{l}1.22 .20 \\
\text { Manifesting }\end{array}$ & $\begin{array}{l}\text { Shipping manifest per DOE Manual } \\
435.1-1 \text { Chapter N, section I.(2) and } \\
\text { NUREG/BR-0204. Dangerous waste } \\
\text { labeling per WAC 173-303-370 and } \\
\text { RCRA permit }\end{array}$ & $\begin{array}{l}\text { Documentation will be provided at time } \\
\text { of container transfer to DOE. } \\
\text { Containers will be properly labeled. }\end{array}$ \\
\hline $\begin{array}{l}\text { 1.2.2.21 Waste } \\
\text { Form Testing - } \\
\text { Leachability } \\
\text { Index }\end{array}$ & $\begin{array}{l}\text { Sodium leachability index }>6.0, \\
\text { iodine-129 leachability index }>11.0 \\
\text { and technetium-99 leachability index } \\
>9.0 \text { (90-day ANSI/ANS-16.1 } \\
\text { procedure) }\end{array}$ & $\begin{array}{l}\text { Representative pre-production waste } \\
\text { form samples will be tested to verify } \\
\text { compliance with leachability index } \\
\text { requirements. Production process will } \\
\text { be controlled to achieve desirable } \\
\text { product performance characteristics. }\end{array}$ \\
\hline $\begin{array}{l}1.2 .2 .22 \\
\text { Minimize Waste } \\
\text { Volume }\end{array}$ & $\begin{array}{l}\text { Total SSW volume minimized within } \\
\text { constraints of the other specifications }\end{array}$ & $\begin{array}{l}\text { HSW loading in Ceramicrete will } \\
\text { continue to be optimized within } \\
\text { constraints of the other specifications. }\end{array}$ \\
\hline $\begin{array}{l}1.2 .2 .23 \\
\text { Thermal, } \\
\text { Radiation, } \\
\text { Biodegradation } \\
\text { and Immersion } \\
\text { Stability }\end{array}$ & $\begin{array}{l}\text { SSW shall be resistant to thermal, } \\
\text { radiation, biodegradation and } \\
\text { immersion degradation, as described } \\
\text { in NRC Technical Position on Waste } \\
\text { Form. }\end{array}$ & $\begin{array}{l}\text { Representative pre-production waste } \\
\text { form samples will be tested to verify } \\
\text { compliance with requirements. } \\
\text { Production process will be controlled to } \\
\text { achieve desirable product performance } \\
\text { characteristics. }\end{array}$ \\
\hline $\begin{array}{l}1.2 .3 .1 \\
\text { Package } \\
\text { handling }\end{array}$ & $\begin{array}{l}\text { Package shall be compatible with } \\
\text { crane lifting and movement and } \\
\text { vertical stacking to a height of } \\
10 \text { meters. }\end{array}$ & $\begin{array}{l}\text { Container design will incorporate these } \\
\text { features. Documentation will be } \\
\text { provided. }\end{array}$ \\
\hline
\end{tabular}

\section{II-1.10 Schedule}

Figure 6 provides a preliminary schedule for constructing a facility to immobilize the HSW. We estimate a Ceramicrete Treatment Facility can be operational within 5 years after a decision to proceed. This schedule is a living document that will be updated during subsequent project phases. Schedule acceleration of approximately 1 year is possible given an early start on the concept design in parallel with preliminary assessment work leading to permit initiation. 
Figure 6-Preliminary Schedule, Hanford Secondary Waste Immobilization

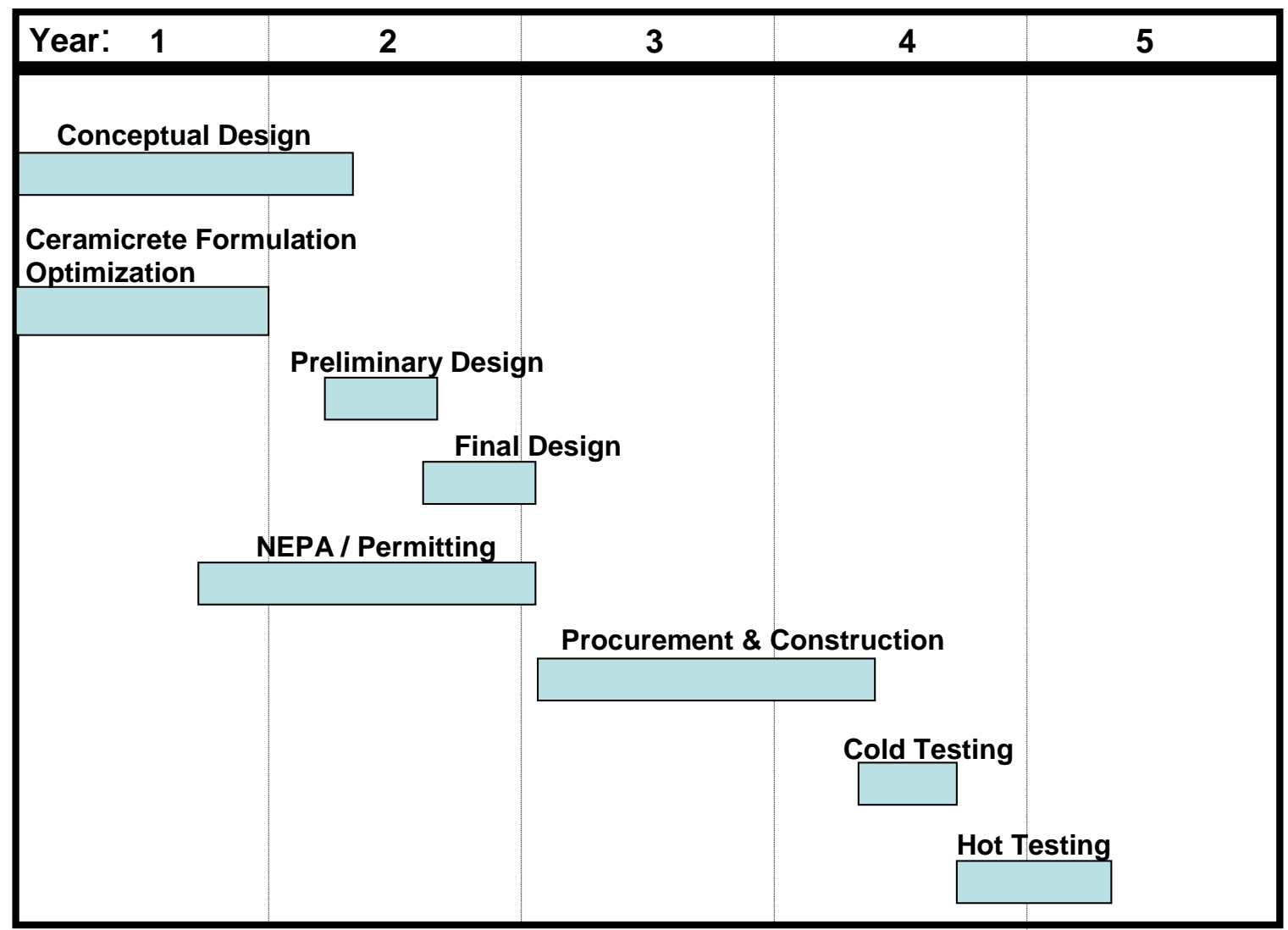

Initially, the Ceramicrete formulation will be optimized in parallel with preparation of the conceptual design. Ceramicrete formulation optimization will include preparation and testing of additional wastes form samples prepared from simulants and actual Hanford secondary waste derived from operation of the Demonstration Bulk Vitrification System. These waste form tests will optimize waste loading and provide additional information on the operating envelope for production of suitable waste forms. Following completion of the conceptual design, the process and facility design will be matured through preparation of a preliminary and final design.

Regulatory activities, commenced during the later part of the conceptual design, will be complete in parallel with the final design and result in issuance of National Environmental Policy Act (NEPA) documentation and necessary permits. Procurement and construction activities will follow issuance of regulatory documents, culminating in commissioning a facility for immobilizing the Hanford secondary waste. 


\section{//-1.11 Cost Estimate}

The estimated cost for construction of the Ceramicrete Treatment Facility for immobilizing Hanford secondary waste is $\$ 48.5$ million. This cost estimate has not been escalated and is in constant 2005 dollars. Details of this cost estimate are summarized in Table 25. This cost estimate includes a 50 percent contingency (\$16.1 million), which is consistent with the level of uncertainty for a project at this stage.

The estimate for the HSW plant assumes a single facility at a scale sufficient to support all WTP high-level waste and low-activity waste operations, and the Supplemental Treatment Plant low-activity waste operations at their design capacity. Smaller units phased to support the different vitrification plants would minimize initial capital costs but not offer the economy of scale of a single large facility. For the Ceramicrete process, the economy of scale is not as significant as other processes having higher inherent unit costs. As discussed above and in Part I of this report, the cost for equipment and materials is based on a water stream and would be lower if the waste were delivered in a dewatered state. We also discussed how the final waste form volume, and hence the containerization and disposal costs, can be reduced. We expect that the load factor would be optimized during the next phase of work, following the studies outlined in Part I.

Table 25-Hanford Low Temperature Waste Immobilization

\begin{tabular}{|l|r|}
$|c|$ & \multicolumn{1}{|c|}{ Estimate Summary } \\
\hline \multicolumn{1}{|c|}{ Description } & \multicolumn{1}{|c|}{ Total Cost (\$) } \\
\hline Other Project Costs & $7,851,847.64$ \\
\hline Program/Project Management & $1,174,656.64$ \\
\hline Technical Support & $1,042,858.48$ \\
\hline Preliminary Design & $1,830,731.04$ \\
\hline Pilot Testing & $2,534,732.40$ \\
\hline Regulatory Permitting/Approval & $1,268,869.08$ \\
\hline Engineering Support & $686,888.00$ \\
\hline Process System & $322,970.00$ \\
\hline Transfer Lines & $140,881.00$ \\
\hline Facilities / Utilities & $223,037.00$ \\
\hline
\end{tabular}




\begin{tabular}{|l|r|}
\hline \multicolumn{1}{|c|}{ Estimate Summary } \\
\hline \multicolumn{1}{|c|}{ Description } \\
\hline Design & \multicolumn{1}{c|}{ Total Cost (\$) } \\
\hline Process System & $2,410,000.00$ \\
\hline 30 Percent Design & $1,550,000.00$ \\
\hline Final Design & $450,000.00$ \\
\hline Engineering During Construction & $900,000.00$ \\
\hline Transfer Lines & $200,000.00$ \\
\hline 30 Percent Design & $310,000.00$ \\
\hline Final Design & $100,000.00$ \\
\hline Engineering During Construction & $200,000.00$ \\
\hline Facilities/ Utilities & $10,000.00$ \\
\hline 30 Percent Design & $550,000.00$ \\
\hline Final Design & $150,000.00$ \\
\hline Engineering During Construction & $350,000.00$ \\
\hline Procurement & $50,000.00$ \\
\hline Process Equipment & $8,363,168.92$ \\
\hline Procurement & $2,571,800.20$ \\
\hline Procurement Support & $2,240,727.00$ \\
\hline Transfer Lines and Pits & $331,073.20$ \\
\hline Procurement & $5,422,583.00$ \\
\hline Procurement Support & $5,253,633.00$ \\
\hline Facilities/ Utilities & $168,950.00$ \\
\hline Procurement & $368,785.72$ \\
\hline Procurement Support & $319,485.00$ \\
\hline Installation & $49,300.72$ \\
\hline Process System & $12,359,287.86$ \\
\hline Program Management/Construction Management (PM / CM) & $1,746,070.80$ \\
\hline Construction & $305,642.50$ \\
\hline Construction Support & $1,363,576.30$ \\
\hline Transfer Lines & $76,852.00$ \\
\hline PM / CM & $3,498,829.69$ \\
\hline Construction & $175,401.50$ \\
\hline Construction Support & $3,255,002.19$ \\
\hline Facilities/ Utilities & $68,426.00$ \\
\hline PM / CM & $7,114,387.38$ \\
\hline Construction & $415,784.00$ \\
\hline
\end{tabular}




\begin{tabular}{|c|r|}
\hline \multicolumn{2}{|c|}{ Estimate Summary } \\
\hline \multicolumn{1}{|c|}{ Description } & Total Cost (\$) \\
\hline Readiness / Startup & $668,612.20$ \\
\hline Process System & $440,850.34$ \\
\hline Readiness/Startup & $440,850.34$ \\
\hline Transfer Lines and Pits & $215,167.98$ \\
\hline Readiness/Startup & $215,167.98$ \\
\hline Facilities/Utilities & $12,593.88$ \\
\hline Readiness/Startup & $12,593.88$ \\
\hline Operations & 0.00 \\
\hline Operations & \\
\hline Operations & \\
\hline Operations Support & \\
\hline Maintenance/Consumables & \\
\hline Maintenance & $\mathbf{4 8 , 5 0 9 , 7 0 6 . 9 3}$ \\
\hline Consumables & \\
\hline Tlosure & $\mathbf{3 2 , 3 3 9 , 8 0 4 . 6 2}$ \\
\hline Closure & 0.00 \\
\hline Decontamination and Decommissioning (D\&D) & \\
\hline Subtotal & \\
\hline Contingency (50 Percent) & \\
\hline
\end{tabular}

\section{II-2 Process Description-Idaho SBW}

During the bench-scale demonstration work described in Part I of this report, we immobilized not only SBW as-received simulants, but also simulants that we spiked with Cs and other radioactive surrogates. For a full-scale facility concept, we assumed the Cs content would justify including a Cs separation step in the process. That is, we envision separating SBW into a Cs-rich, high solids fraction and a Csdepleted supernatant fraction. Both fractions would be immobilized using Ceramicrete to meet the performance criteria for acceptance at the WIPP, and for the national repository if needed. Figure 7 is a schematic block diagram for this approach to immobilizing SBW in two fractions. The upper part of the diagram represents a remote operated system in a shielded cell; the lower part of the diagram represents a conventional, low-activity operation. 
Figure 7 - Block Flow Diagram-CsPTA Separation and Ceramicrete Immobilization of Separate $\mathrm{RH}$ and $\mathrm{CH}$ Waste Fractions

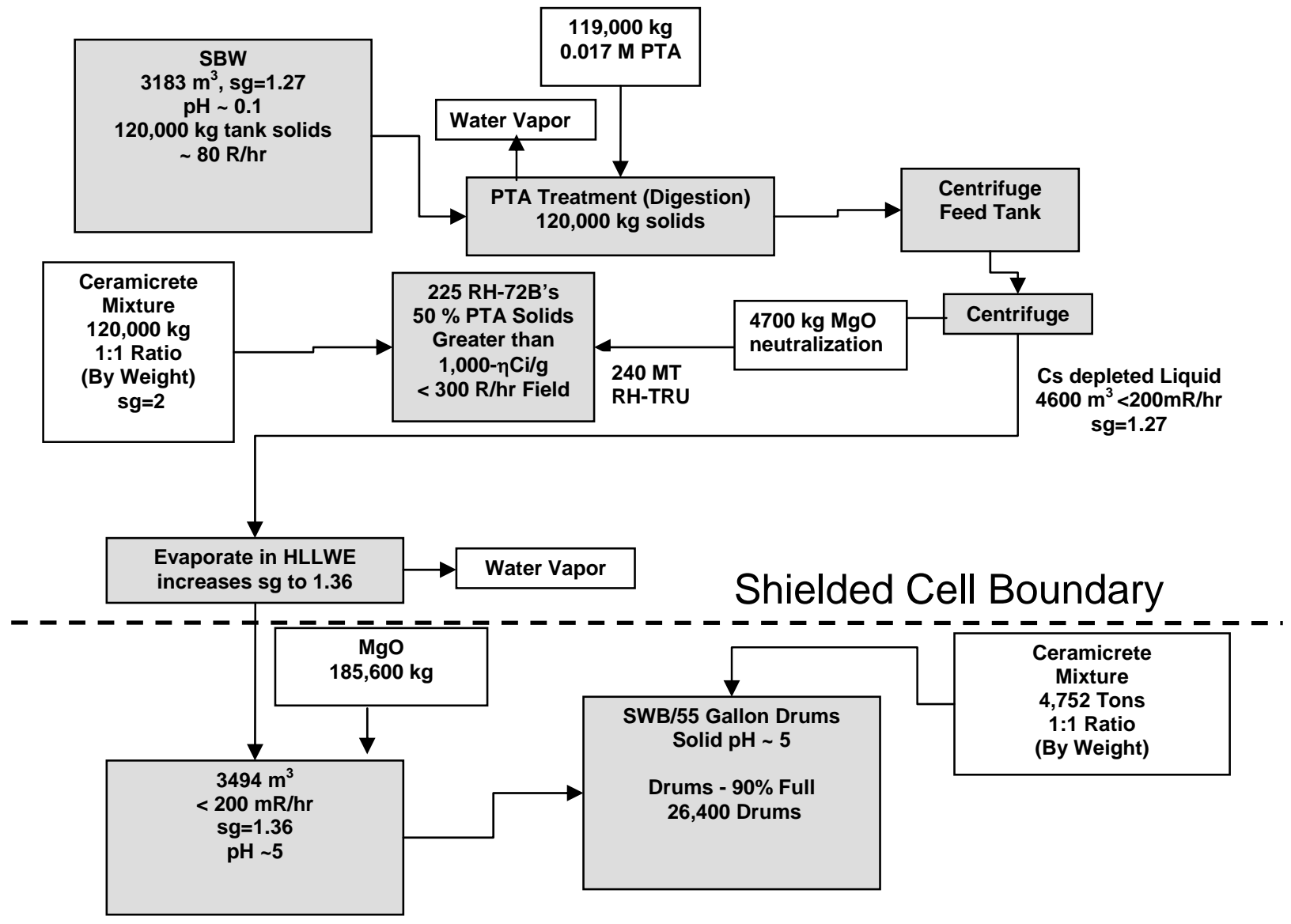

\section{II-2.1 Cs Enriched Fraction}

An attractive alternate method for treatment of Idaho's SBW relies on the separation and removal of radioactive Cs from the SBW acidic liquid waste by using phosphotungstic acid (PTA) to precipitate Cs, followed by a centrifuge. The precipitated Cs/PTA mixture is placed into $\mathrm{RH}-72 \mathrm{~B}$ payload canisters and immobilized using a Ceramicrete binder. As prescribed in the demonstration work and described above for HSW, this stream would be managed with a partial neutralization $\rightarrow$ reagents addition $\rightarrow$ ceramic mixing process train. Approximately 225 remote-handled $(\mathrm{RH})$ canisters will contain all the Cs/PTA material as well as the tank farm undissolved solids.

The Cs/PTA process has been proven in 4 years of production runs on acidic waste streams at DOE's Hanford complex. In addition, recent radioactive, bench- 
scale tests have shown the process works for surrogate SBW. Final proof tests are indicated with actual SBW before a final commitment is made to this treatment technology. These tests have now been performed at the Idaho Nuclear Technology and Engineering Center (INTEC). The results of these tests are very positive and should lead to a go/no-go decision early in the Idaho Cleanup Project (ICP) contract period. The Cs separation factor is ten times better than needed to justify the process.

\section{II-2.2 Cs Depleted Fraction}

The supernatant will exhibit radiation fields less than 200 millirem/hour, thus allowing simpler and cheaper contact-handled $(\mathrm{CH})$ immobilization and handling. The contact-handled solution will also be immobilized with Ceramicrete. Just as with the $\mathrm{RH}$ stream, the HSW, and the demonstration simulants, this $\mathrm{CH}$ stream would be managed according to the same process train, in this case including a partial evaporation step to reduce the final volume. Approximately $26,400 \mathrm{CH}$ drums will be generated. Optimization studies yet to be done may show that a much smaller number of standard waste boxes (SWBs) would be more cost effective, even if weight limited. As was the case with HSW, the volumes assumed for this concept report are conservative and may be reduced in ways that were discussed previously in this report.

\section{II-2.3 Deployment Concept and Integration with Other Idaho National Laboratory Facilities}

\section{II-2.3.1 Deployment Concept}

Using the Cs/PTA-Ceramicrete technical approach, both of which are nonthermal pre-treatment processes, all SBW would be removed from the high-level waste tanks and immobilized in road-ready containers within 36 months of contract inception. Both the $\mathrm{RH}$ and the $\mathrm{CH}$ Ceramicrete process lines follow the same general steps outlined in Part I and the HSW reports above. All of the process steps are known and in wide use, using equipment commercially available in the hazardous waste industry and at DOE sites. Total costs, including design, construction, startup, operations, consumables, and decontamination and removal of the equipment, are estimated to be $\$ 62.7$ million (85 percent confidence level, based on previous studies), as itemized in Table 26. 


\section{II-2.3.2 Integration with Other INL Facilities}

The Cs/PTA separation process and Ceramicrete immobilization process would take place entirely within an existing process building at the INTEC; specifically, the New Waste Calciner Facility (NWCF). The NWCF process building, designated CPP-659, was previously used to solidify radioactive high-level liquid waste using fluidized bed calciner technology. The calcination operations were terminated in 2001 due to regulatory and air emissions concerns. Other operational activities continue, including HEPA filter leach and RCRA debris treatment. Thus, the facility continues in a fully operational $24 / 7$ status that can easily accommodate the proposed Cs/PTA/Ceramicrete operation. Hot cell Room 214 would be refurbished for the remote-handled work (see Figures 8 and 9); Room 427 would be refurbished for contact-handled work (see Figure 10). Interim storage of the remote-handled canisters would occur in an unused existing building, CPP-691. Interim storage of the contact-handled waste boxes would occur in the existing CPP-1617 outdoor enclosure.

Figure 8-Room 214 Calciner Cell Cesium/Solids Separation/Immobilization Plan View

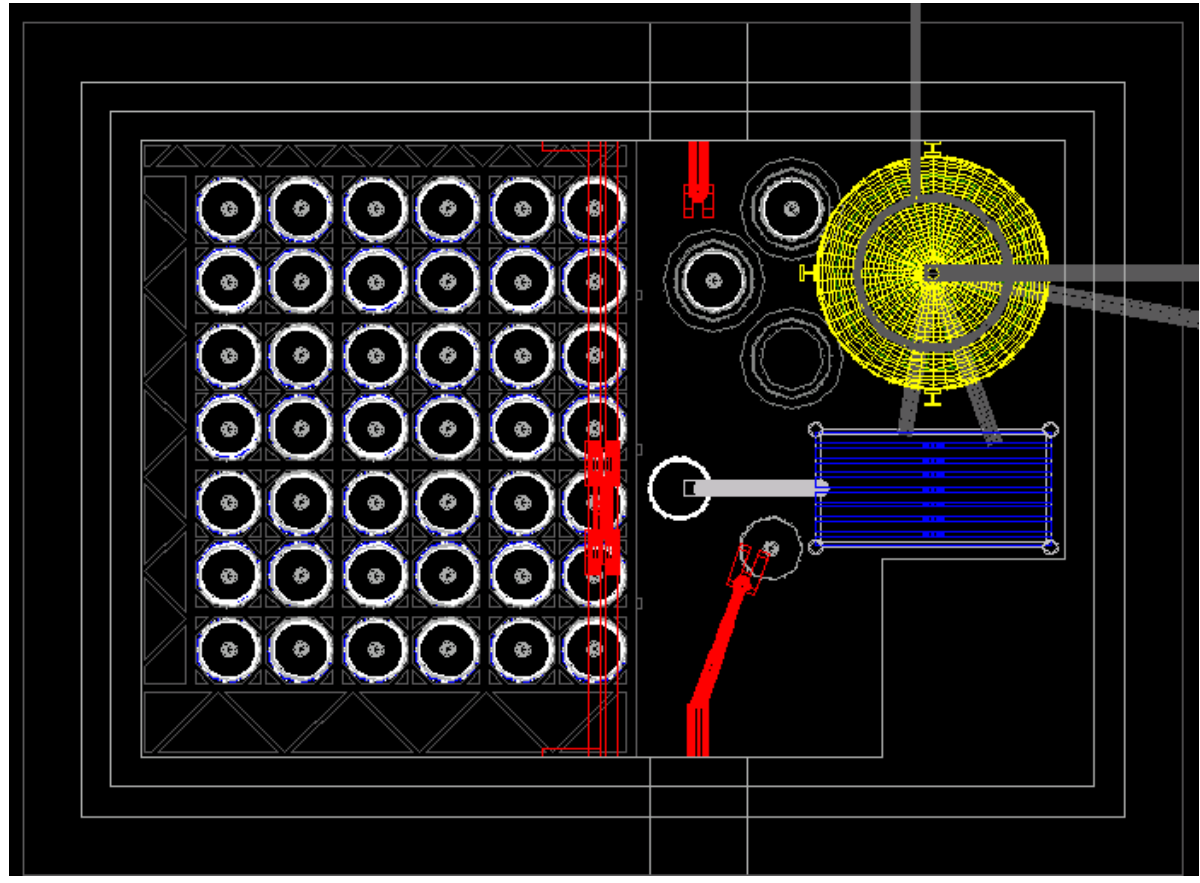


Figure 9-Room 214 Calciner Cell Cesium/Solids Separation/Immobilization Concept for RH Fraction

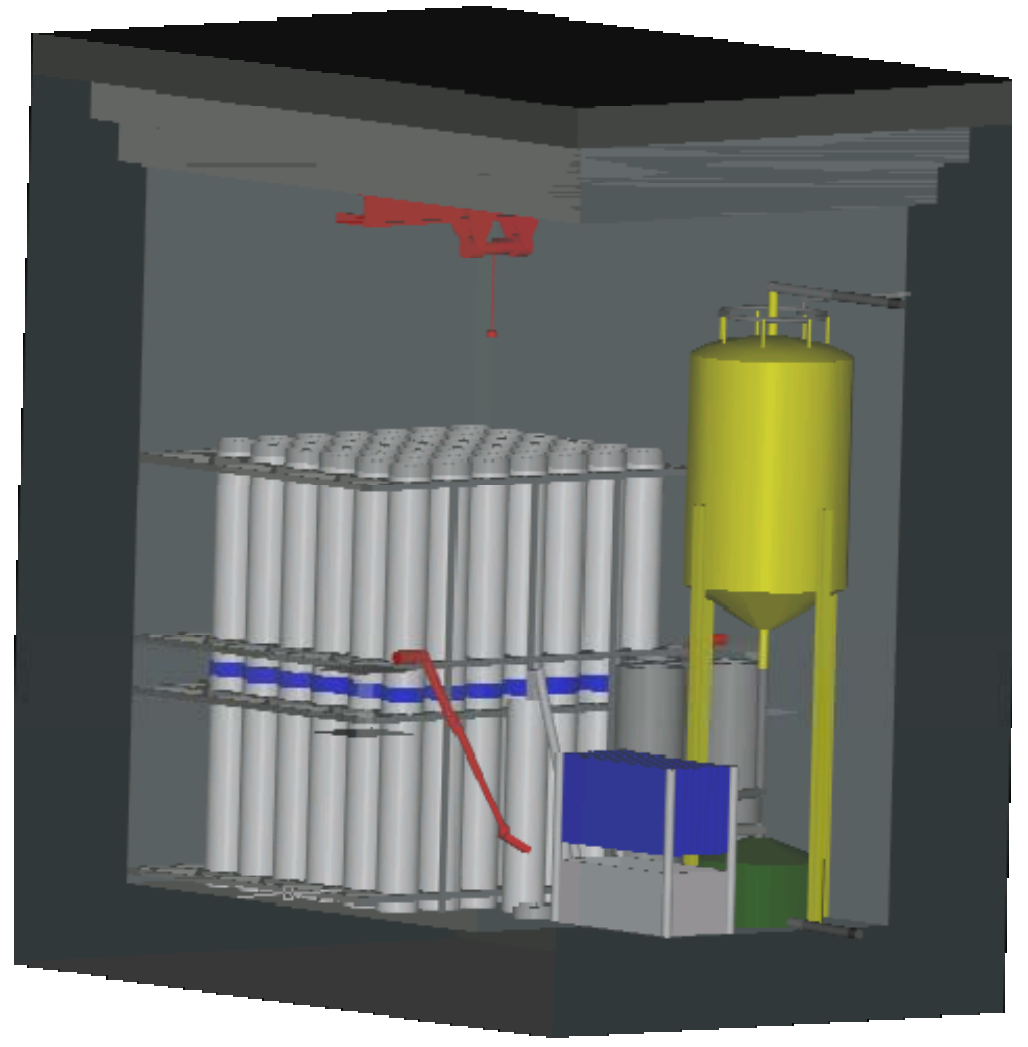

\section{II-2.3.2.a CS/PTA/Ceramic Remote Process Integration}

In order to maximize site infrastructure integration, the concept envisioned for this report is that the Cs/PTA separation process be installed into the existing calciner shielded hot cell Room 214, in CPP-659 (Figures 8 and 9). This is a very large, shielded hot cell approximately 34 feet high, 31.5 feet long, and 21 feet deep. This cell includes two shielded windows each with a set of manipulators. Use of the cell for Cs/PTA is ideal since the SBW is already piped from the tank farm into the cell via several large receiver vessels located in the adjacent blend-and-hold cell, Room 213. Additionally, Room 214 has both process exhaust and room exhaust ventilation which can be re-used as necessary, as well as numerous piping penetrations which can be used for reagent additions into the cell.

A feature of Room 214 which complicates its use for Cs/PTA/Ceramicrete is the need to remove the existing calciner vessel and associated cyclone separator to make room for the new equipment. The 84-inch-diameter calciner vessel is 18 feet 
tall. It has been cleaned to RCRA closure specification, but a residual radiation field of several hundred millirem/hour still exists. The calciner would be disconnected from all piping connections and lifted out intact through the large hatch in the roof cell. Removal of the calciner vessel and associated equipment is included in the cost estimate (because it is not included in the ICP scope).

After the excess equipment is removed, installation of the new equipment can begin. This equipment consists of an in-cell crane, 4,000-gallon digester vessel, an industrial centrifuge, a centrifugal pump for the supernatant, a screw conveyor, a $\mathrm{RH}-72 \mathrm{~B}$ loading station, and in-cell lag storage. All of this equipment is commercially available. Description of each equipment unit follows:

- The crane is 10-T single girder overhead crane that will be used to move canisters around within the cell. The maximum lift height is 32 feet.

- The 4,000-gallon digestion tank is sized to process a batch size sufficient to fill one $\mathrm{RH}-72 \mathrm{~B}$ for each batch. The 8-foot-diameter, 11-foot-tall vessel is constructed of $316 \mathrm{~L}$ stainless steel. Multiple in-vessel spargers using nitrogen gas are used to ensure good mixing and digestion.

- A vertical 75-gpm centrifuge, producing 1,600 G force, is used to separate solids from water. A second, full-installed spare centrifuge is also included in the design and estimate to avoid significant downtime if the primary unit fails.

- A screw conveyor will move the semi-dewatered solids from centrifuge to the canister loading station. Neutralizer, stabilizer, and Ceramicrete binder chemicals will be kept outside the hot cell. The $\mathrm{MgO} / \mathrm{NaOH}$, reagent additives, and Ceramicrete binder will piped into the walls of the screw conveyor to ensure good mixing. The SWB will first be neutralized and the temperature allowed to drop before the binder is introduced. Any residues after canister loading would be washed down and recycled back to the centrifuge inlet.

- The loading station will position each empty canister for the filling and lid closure operation. The $\mathrm{RH}-72 \mathrm{~B}$ canisters would use the bolted closure option, which would be performed using the existing remote manipulators. 
- The in-cell canister storage system is an innovative cable structure which allows 98 canisters to be in-cell in a double deck fashion. Each loaded canister on the bottom level will have a separate crush pad that can protect the canister in the event the top canister, fully loaded, falls onto the bottom canister during handling operations. The storage array has been designed to withstand the CPP-659 design basis earthquake of $0.22 \mathrm{~g}$ horizontal and 0.147 vertical accelerations.

Instrumentation for the above equipment is included in the estimate. A gamma level measurement system will used to ensure proper fill level for the canister.

Because Room 214 can only hold 99 canisters at one time, it will be necessary to stop processing operations to remove the filled canisters through the roof hatch. The transfer-out operation will take approximately 1 month. The cost estimate includes the purchase of two $\mathrm{RH}-72 \mathrm{~B}$ shielded transport casks to accelerate the loaded canister removal activity, thus decreasing the in-cell process downtime. The loaded $\mathrm{RH}-72 \mathrm{Bs}$ will be moved to outdoor modular shielded storage units, also included in the cost estimate.

\section{II-2.3.2.b Contact Handled Ceramic Process Integration}

The supernatant leaving the centrifuge, which is now $<200 \mathrm{mr} /$ hour, will be pumped to Room 427, which is located approximately 125 feet from the remote processing cell (Figures 10 and 111). Room 427 was the cold calcium nitrate makeup room, and is currently unused. The room has immediate access to the outside loading/unloading dock and is located on the NWCF main operating floor. Some equipment modification would be necessary to use this room for the SBW supernatant ceramicrete immobilization process; however, several existing equipment items-such as the holding tank and the calcium nitrate storage and feeder hopper vessels-can possibly be reused for the supernatant and the Ceramicrete binder materials, respectively. The necessary modifications are included in the cost estimate. 
Figure 10-Room 427 Supernate Immobilization Process Concept Using SWB Containers

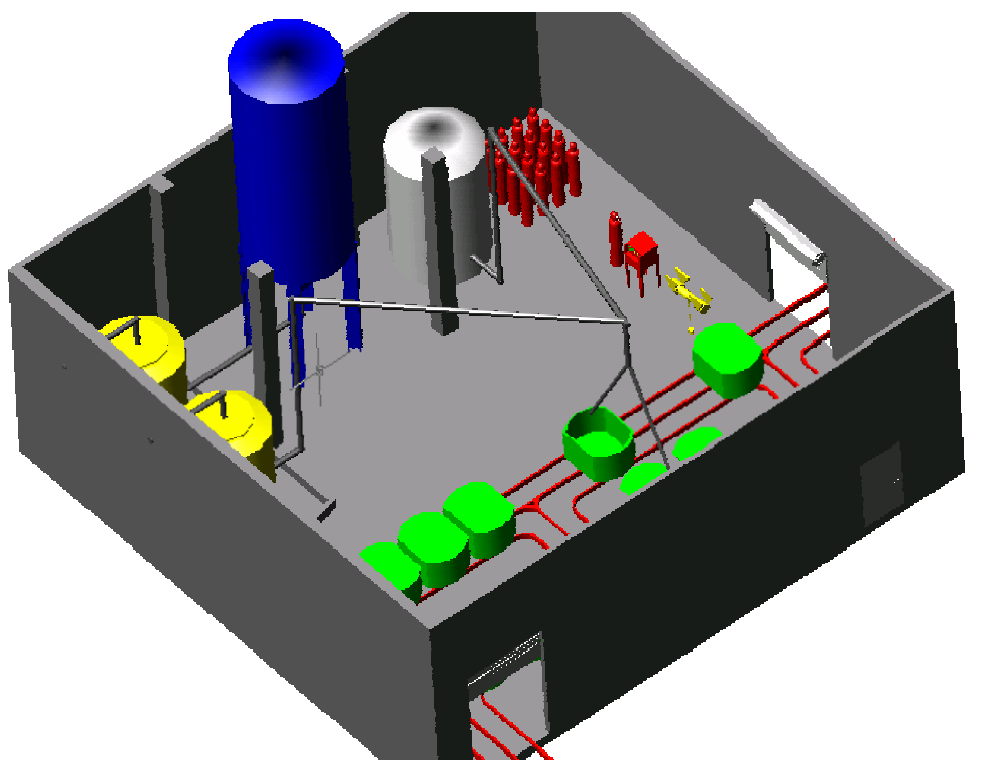

Figure 11-Room 427 Supernate Immobilization Plan View Using Drums

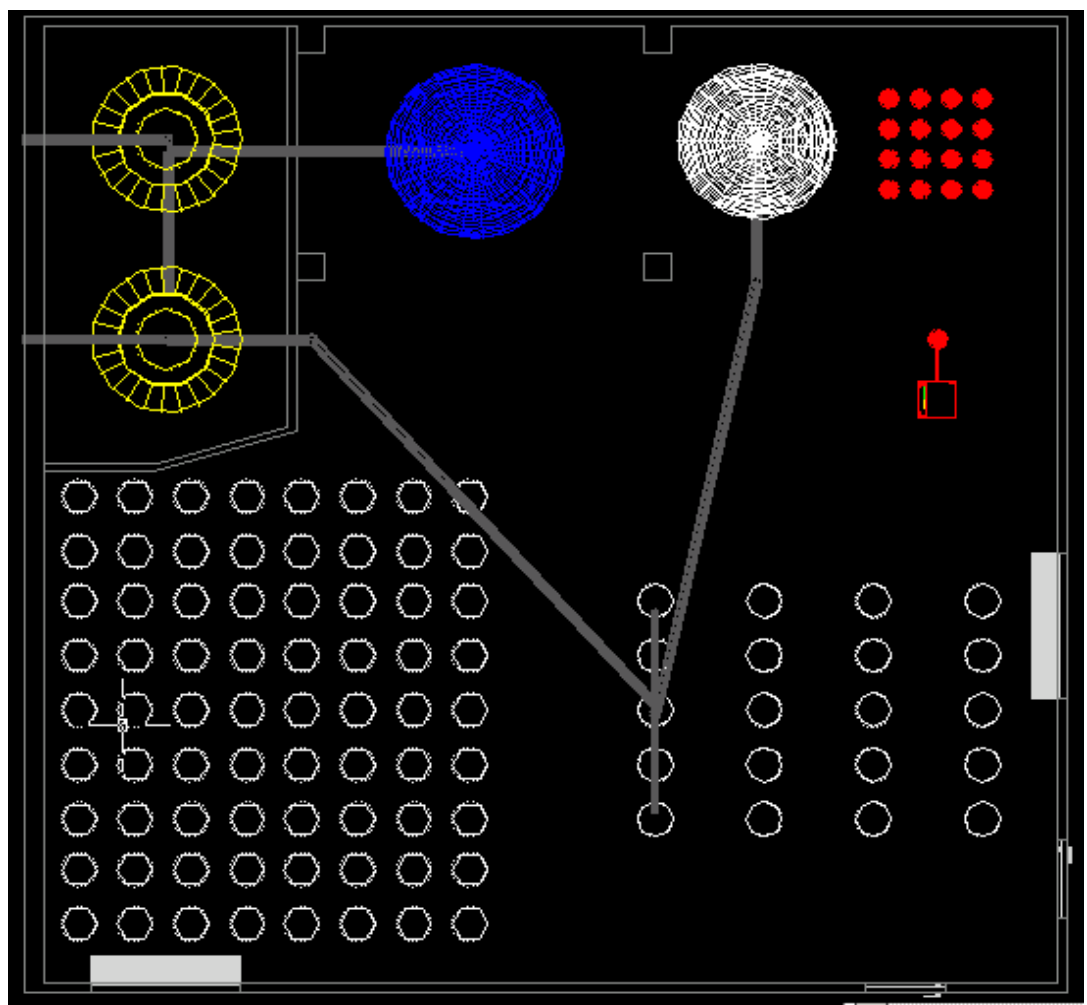


A portion of the transfer line from Room 214 may be fitted with a screw conveyor with provision to introduce $\mathrm{MgO} / \mathrm{NaOH}$ for neutralization and reagents if needed for $\mathrm{Hg}, \mathrm{Cr}$, and possibly Tc, I, and Cs. Alternatively, these processes may be carried out in-drum in a small-scale, manual operation. Vapors generated may be collected using an "elephant trunk" hose setup. For partial evaporation, the existing HLW evaporator in the adjacent cell may be used, although it would have only low activity duty for the supernatant. After dewatering this stream to an economic volume, the Ceramicrete binder pre-mix would be introduced in a purpose-built mixer, as an alternative to the in-drum paddle method. The scale of these unit operations is about half that of the Hanford HSW facility and the facility will operate less than 1 year compared to perhaps 20 years at Hanford.

Since the liquid waste is now $<200 \mathrm{mr} / \mathrm{hr}$, a manual drum filling operation is envisioned. Because air-borne contamination is a concern, operators would work with air-fed anti-C protection or self-contained breathing apparatus (SCBA) gear. Although many drums would need to be processed, an around-the-clock operation would need to process approximately five drums per hour.

The proposed approach is to fill a 55-gallon drum with the appropriate quantity of waste liquid, introduce the Ceramicrete, and mix the drum with a portable stirrer which is manually moved from drum to drum. Approximately five drums would be processed concurrently in each batch. A vent hood, or other suitable ventilation system, would be used to direct any fumes released during the mixing and solidification processes to the existing CPP-659 ventilation system, which is HEPA filtered and released to the monitored building exhaust stack. It is anticipated that the small amount of fume releases will be well within the existing NWCF air emissions permit; however, further testing and calculations will be necessary.

After drum solidification, a visual check for no free liquid will be made at approximately 2 hours. If a satisfactory condition is noted, the drum lid will be attached and closed. The lids will have the WIPP-prescribed filter. The drums will be checked for contamination and labeled per WIPP requirements. The drums will then be moved out of Room 427 onto the adjacent loading dock. A flatbed truck will take 
the finished drums to CPP-1617, an INTEC outdoor fenced area which is approximately $1 / 2$ mile away.

Because significant drum movement will occur within Room 427, the design includes a non-motorized drum movement system installed on the floor, such as a wheeled conveyor system. The operators would push drums along the installed tracks to the various processing stations.

As can be seen from the foregoing description, the drum filling and solidification approach is labor intensive. Since only an 8-month production period is anticipated, increased mechanization is assumed to be unwarranted. This concept may be changed in the next phase of evaluation. Although the described worker safety is adequate, when conceptual and preliminary design occurs, opportunities to improve worker safety should be investigated.

Although a drum-scale operation is assumed for the Cs-depleted fraction, the same process could be employed using SWBs or other container designs. This would greatly reduce the amount of handling and the number of containers to be shipped for disposal. Although standard waste boxes (SWBs) may be weight-limited, it may still be cost-effective to use them, once all packaging, handling, certification, shipping, and disposal costs are taken into account. Those trade studies have not been done for this concept report. Figure 10 shown earlier, is a schematic of Room 427 with an SWB operation. Figure 11 shows a possible drum operation layout.

\section{II-2.4 Cost and Schedule Estimate}

Table 26 provides the conceptual integrated cost and schedule for the complete Cs/PTA - Ceramicrete project to immobilize SBW. This is a lifecycle concept that includes design, permitting, engineering, procurement, and construction (EPC), operation and maintenance (O\&M), decommissioning, and closure. It also includes preparation of existing infrastructure, such as removal of the existing calciner. As discussed in Part I and the introduction to Part II of this report, the estimates are conservative with respect to the assumed volumes of both pretreated SBW and immobilized SBW, and the associated equipment, materials, containers, and disposal. 
The labor estimate incorporated in these figures is $\$ 180,000$ per person-year. This value incorporates burdens such as safety and quality. Actual wage scale rates, plus actual allocated indirect and overhead, may result in a lower overall project estimate.

The cost estimate takes certain schedule risk management expenses into account, such as nearly $\$ 5$ million for procurement of an onsite $72 \mathrm{~B}$ transport system. This may not be needed, depending on the steam reformer project.

A 30-month schedule is indicated. A number of steps could be taken to compress the schedule if needed. Building preparation work could be advanced and conducted along with utility interface work in parallel with detail design and engineering for the new facilities and equipment. Some pilot plant equipment at the Science and Technology Applications Research Center (STAR) could be installed in the facility at INTEC directly, and full-scale assemblies could be made in advance of installation.

Table 26-Time and Cost Schedules for SBW Immobilization

\begin{tabular}{|l|c|r|}
\multicolumn{1}{|c|}{ Item } & $\begin{array}{r}\text { Duration } \\
\text { (months) }\end{array}$ & \multicolumn{1}{c|}{ Cost } \\
\hline 1.1 Develop design requirements & 3 & $\$ 270 \mathrm{~K}$ \\
\hline 1.2 Develop permit application & 4 & $820 \mathrm{~K}$ \\
\hline Plot plan & & \\
\hline Quantified flow diagram & & \\
\hline $\begin{array}{l}\text { Emission Min and Maximum Available Control Technology } \\
\text { (MACT) Plan }\end{array}$ & & \\
\hline Permit to construct & & \\
\hline Title V air permit & & \\
\hline Screening level risk assessment & & \\
\hline 1.3 Conduct NEPA supplement analysis & 4 & $150 \mathrm{~K}$ \\
\hline 1.4 Prepare preliminary safety analysis & 6 & $2,450 \mathrm{~K}$ \\
\hline 1.5 Develop in-cell rip-out plan & 4 & $360 \mathrm{~K}$ \\
\hline 1.6 Design in-cell Cs/PTA equipment & 6 & $3.600 \mathrm{~K}$ \\
\hline 1.7 Design building ex-cell modifications & 4 & $1,800 \mathrm{~K}$ \\
\hline 1.8 Procure in-cell equipment (RM-214) & 6 & $8,270 \mathrm{~K}$ \\
\hline Cs/PTA digester tank system & & \\
\hline Centrifuge dewater & & \\
\hline In-cell crane system & & \\
\hline
\end{tabular}




\begin{tabular}{|c|c|c|}
\hline Item & $\begin{array}{l}\text { Duration } \\
\text { (months) }\end{array}$ & Cost \\
\hline \multicolumn{3}{|l|}{ Solids screw auger to fill $72 \mathrm{~B}$} \\
\hline \multicolumn{3}{|l|}{ Ceramicrete addition system with mixer } \\
\hline \multicolumn{3}{|l|}{ Storage racks for filled units } \\
\hline 1.9 Procure ex-cell equipment (RM-427) & 4 & $1,500 \mathrm{~K}$ \\
\hline 1.10 Procure 15 units shielded lag storage & 6 & $3,090 \mathrm{~K}$ \\
\hline 1.11 Procure onsite 72B Transport system (2) & 12 & $4,960 \mathrm{~K}$ \\
\hline 1.11 Assemble Cs/PTA equip at STAR/test & 3 & $1,360 \mathrm{~K}$ \\
\hline 1.12 Rip-out Room 214 equipment & 5 & $1,300 \mathrm{~K}$ \\
\hline 1.13 Move equipment from STAR to INTEC & 1 & $545 \mathrm{~K}$ \\
\hline 1.14 Install in-cell and ex-cell mods & 3 & $1,905 \mathrm{~K}$ \\
\hline $\begin{array}{l}\text { 1.15 Conduct integrated testing, Management Readiness Assessment } \\
\text { (MRA), Operational Readiness Review (ORR) }\end{array}$ & 8 & $7,500 \mathrm{~K}$ \\
\hline 1.16 Provide project management & 30 & $2,250 \mathrm{~K}$ \\
\hline \multicolumn{2}{|l|}{ Capitol Subtotal } & $42,130 \mathrm{~K}$ \\
\hline 2.1 Conduct production operations & 8 & $6,600 \mathrm{~K}$ \\
\hline 2.2 Procure $\mathrm{RH}-72$ B canisters (225) & -- & $3,375 \mathrm{~K}$ \\
\hline 2.3 Procure 55-gallon drums, liner/filter $(26,404)$ & -- & $2,957 \mathrm{~K}$ \\
\hline 2.4 Procure dry PTA & -- & $5,236 \mathrm{~K}$ \\
\hline 2.5 Procure dry Ceramicrete reagents & -- & $877 \mathrm{~K}$ \\
\hline \multicolumn{2}{|l|}{ Operations Subtotal } & $19,045 \mathrm{~K}$ \\
\hline 3.1 Conduct D\&D of Room 214 & 6 & $1,180 \mathrm{~K}$ \\
\hline 3.2 Clean up Room 427 & 2 & $150 \mathrm{~K}$ \\
\hline 3.3 Conduct miscellaneous cleanup activities & 3 & $180 \mathrm{~K}$ \\
\hline \multicolumn{2}{|l|}{ D\&D\&D Subtotal } & $1,510 \mathrm{~K}$ \\
\hline \multicolumn{2}{|l|}{ Project Total } & $62,685 \mathrm{~K}$ \\
\hline
\end{tabular}

\section{II-3 Uncertainties, Risks, and Potential Safety Issues}

This section describes uncertainties, risks, and potential safety issues that have initially been identified with the Ceramicrete immobilization process for HSW and Idaho SBW. Hazards and operability (HAZOP) studies will be conducted for each treatment process during subsequent project phases to systematically identify and mitigate hazards.

In comparison with many alternative treatment technologies, the process defined here for Ceramicrete immobilization does not comprise many uncertainties. The Ceramicrete technology is mature, all of the process steps are widely used in the 
hazardous waste industry, and all of the equipment items needed are commercially available and have long operating records. Yet it is important to keep in mind that this is a chemical and physical process with technology risk like any other grout operation; namely, the actual waste delivered needs to be analyzed carefully in every case so that the reagents and binder chemicals are adjusted for compatibility with the waste constituents before one can be confident that the formula, each of the process steps, and the ceramic waste form will all perform as designed.

\section{II-3.1 Hanford Secondary Waste}

\section{II-3.1.1 Curing of Ceramicrete}

Ceramicrete, produced in 55-gallon drums, cures in less than 24 hours. Since the Ceramicrete acid-base reactions are exothermic, the temperature of the mix will rise and then cool, much as any grout process. The maximum temperature reached during curing was $80^{\circ} \mathrm{C}$ for Ceramicrete contained in 55-gallon drums. Thermal modeling is necessary to verify the curing time and maximum temperature for Ceramicrete in the proposed $2.26-\mathrm{m}^{3}$ container. This thermal modeling can be conducted at the beginning of the next phase of this project to verify the size of the interim storage for the Ceramicrete-immobilized HSW. Large-scale operations in which Ceramicrete is used to build road and bridge sections, housing, and nuclear shielding vaults, indicates that the temperature does not reach boiling at any point. For the HSW and SBW applications, a simple confirmatory test would be part of the scale-up study.

\section{II-3.1.2 Evaporator Process Condensate}

The SALDS currently receives liquid effluent from the Hanford 200-East ETF. A permit modification will likely be required to accept process condensate from evaporation of the HSW. Additionally, the capacity of the SALDS is unknown for acceptance of process condensate from evaporation of the HSW. If disposal at the SALDS is not acceptable, the process condensate from evaporation of the HSW could be transferred to the 200-East ETF for further treatment. 


\section{II-3.1.3 Chemical Hazards}

The hazards of phosphoric acid (CAS number 7664-38-2), stannous chloride (CAS number 7772-99-8), sodium fluoride (CAS number 7681-49-4), silver zeolite, magnesium oxide (CAS number 1309-48-4) and potassium monophosphate (CAS number 7778-77-0) are well known and documented on material safety data sheets. No unusual safety hazards are known to exist.

\section{II-3.1.4 Interfaces}

The interfaces for the HSW immobilization process have not been defined in the RFP, leading to uncertainty in the quantities and need for interface infrastructure. For example, a nominal quantity (4,500 feet) of underground pipeline has been assumed for transfer of secondary waste to the Ceramicrete Treatment Facility. This may be inadequate, depending on the location of the WTP ILAW Facility and the future Supplemental LAW Treatment Facility. These interfaces should be developed further during subsequent phases of this project.

\section{II-3.2 Idaho SBW}

\section{II-3.2.1 Uranium Exceeding Fissile Limits}

The PTA reagent may concentrate uranium in the Cs/PTA solids sufficient to cause a critical safety issue. Surrogate SBW solutions have been spiked with U-235 to determine criticality potential. In all experiments conducted to date, the decontamination factor (DF) for uranium was approximately 2. Given the very low uranium concentrations in the SBW, there is not a critical safety issue based on mass concentration limits.

\section{II-3.2.2 Equipment Malfunctions in the Remote-Handled Cell}

All significant failure modes have been evaluated and none will cause cell breech or environmental consequences. In addition, engineered features have been provided to mitigate in-cell equipment failures, such as container dropping.

\section{II-3.2.3 Manual Drum Filling}

The manual drum filling, solidification, and closure operations for the $\mathrm{CH}$ waste pose some potential personnel safety risks. However, these types of manual 
operations have been successfully and safely employed at Rocky Flats and other locations.

\section{II-3.2.4 Idaho Tank Waste Acceptance for WIPP Disposal}

Although our solidified product will meet all the physical parameters of the WIPP acceptance criteria, there remains a risk that the material would not be accepted at WIPP. A class 3 modification to the WIPP RCRA Part B permit must be approved by the State of New Mexico for disposal of the SBW. If a class 3 permit modification is not granted, the product would need to go to the spent nuclear fuel and HLW repository at Yucca Mountain. At present, RH-72B canisters are not an approved container for disposal at Yucca Mountain; thus, work to show compliance of the $\mathrm{RH}-72 \mathrm{~B}$ canister with the spent nuclear fuel (SNF) and HLW repository requirements would be needed. Alternatively if the repository question is settled before the $\mathrm{CH}$ waste is generated, the Yucca-approved SNF standard canister could be used instead of the $\mathrm{RH}-72 \mathrm{~B}$ canisters. The $\mathrm{CH}$ waste filling approach would change along with an estimated 10 to 25 percent increase in project costs.

\section{II-3.2.5 Chemical Hazards}

The hazards of PTA (CAS number 12501-23-4) and the chemicals listed above for HSW are well known and documented on material safety data sheets. No unusual safety hazards are known to exist.

\section{II-4 References}

1. T.V Healy, Atomic Energy Research Establishment, Harwell, Part I. Preparation of Some Normal and Acid Phosphotungstates, July 1963

2. S.J. Beard and W.C. Schmidt, Purex Plant Test of the Cesium Phosphotungstate Process, HW-81092, March 1964.

3. D.E. Larson, B-Plant Recovery of Cesium from Current Acid Wastes by Phosphotungstate Precipitation, ARH-564, April 1968

4. P.M. Arnold and L.C. Carpinelli, Jr., Evaluation of Phosphotungstic Acid Process for Removal of Cesium-137 from Purex Current Acid Waste, ARH-CD-917, March 1977 
5. A.L. Olson, et. al., Evaluation and Selection of Aqueous-Based Technology for Partitioning Radionuclides from ICPP Calcine, WINCO-1171, Feb 1993.

6. R.J. Orth, K.P. Brooks and D.E. Kurath, Review and Assessment of Technologies for the Separation of Cesium from Acidic Media, PNL-9874, September 1994.

7. Nicholas Ohler, Properties and Reactivity of Keggin Structures, University of California-Berkley, May 2002.

8. C.M. Barnes, S.K. Janikowski, and C.B. Millet, Feed Composition for the Sodium Bearing Waste Treatment Process, INEEL/EXT -2000-01378, Rev 3, Sept. 2003

9. Ben Roberts, et. al., Phosphotungstic Extraction of Cesium from Sodium Bearing Waste, a design report, Idaho State University, May 2004.

10. Ann E. Visser, Phosphotungtic Acid Removal of Radioactive Compounds, Savannah River National Laboratory, May 2004. 
Attachment E-Hydroceramic Cement Final Report 
FINAL REPORT

PNNL RFP 5529

\title{
Low Temperature Waste Immobilization Using Hydroceramic Cement
}

\author{
Ronald A. Palmer, Ph. D. \\ Diagnostic Instrumentation \& Analysis Laboratory \\ Mississippi State University \\ 205 Research Boulevard \\ Starkville, MS 39759
}

May 8, 2006 


\section{OBJECTIVES}

The key goal of the proposed work is the immobilization of the radionuclides and other toxic elements contained in the targeted wastes by the use of hydroceramic cements. Hydroceramic cements have the potential to stabilize the waste streams described in the solicitation without generating an additional secondary waste stream and with the bulk temperature of the waste form (presumably modeled to full scale) not to exceed $150^{\circ} \mathrm{C}$ during the immobilization process.

Hydroceramic cements [1-4] comprise a class of geopolymeric concretes made from a mixture of calcined clay, sodium hydroxide, water (if needed), and minor additives [5]. When nuclear waste is incorporated in a hydroceramic cement, the waste is chemically trapped into insoluble minerals (such as sodalites or zeolites) having an aluminosilicate cage-like framework of channels and cavities [6]. These minerals are expected to be highly stable in a repository environment because they are found as natural constituents in some potential repository sites [7]. The cage-like framework of hydroceramic has the unique property of being able to trap highly soluble constituents such as sodium and cesium. Hydroceramic cement is inorganic and not flammable, and therefore safe for transportation and storage.

\section{MATERIALS}

\section{Waste Simulants}

We received 38 litres of INEEL Sodium Bearing Waste and 75 litres of the Hanford Scrubber Solution. Table 1 provides our chemical analyses of these solutions with the analyses provided by PNNL ("Target"). (Because we received these simulants so quickly, we did not bother making up our own versions of them.)

\section{Additives}

The additives used to make the hydroceramic waste forms were sodium hydroxide, metakaolin, silica, vermiculite, and sodium sulfide. The metakaolin composition is provided in Table 2 .

Tables 3 and 4 show the series of formulations for the Hanford Scrubber Waste and INEEL Sodium Bearing Waste respectively. 
Table 1. Analyses of Waste Simulants

\begin{tabular}{|c|c|c|c|c|c|c|c|c|c|}
\hline \multirow{2}{*}{ Analyte } & \multicolumn{4}{|c|}{ INEEL Sodium Bearing Waste Simulant } & \multicolumn{4}{|c|}{ Hanford Scrubber Solution Simulant } & \multirow{2}{*}{$\begin{array}{l}\text { Instrument } \\
\text { Used }\end{array}$} \\
\hline & Tested & Target & Unit & \% deviance & Tested & Target & Unit & \% deviance & \\
\hline $\mathrm{Ag}$ & & & $\mathrm{mg} / \mathrm{L}$ & & 25.5 & 23.7 & $\mathrm{mg} / \mathrm{L}$ & 7.6 & $\mathrm{ICP}$ \\
\hline $\mathrm{Al}$ & 15055 & 15514 & $\mathrm{mg} / \mathrm{L}$ & -2.96 & 332 & 297 & $\mathrm{mg} / \mathrm{L}$ & 11.8 & $\mathrm{ICP}$ \\
\hline $\mathrm{B}$ & 110 & 110 & $\mathrm{mg} / \mathrm{L}$ & -0.35 & & & $\mathrm{mg} / \mathrm{L}$ & & ICP \\
\hline $\mathrm{Ca}$ & 1403 & 1464 & $\mathrm{mg} / \mathrm{L}$ & -4.16 & 12.6 & & $\mathrm{mg} / \mathrm{L}$ & & ICP \\
\hline $\mathrm{Cd}$ & 79.9 & 78.7 & $\mathrm{mg} / \mathrm{L}$ & 1.55 & 1.52 & 1.57 & $\mathrm{mg} / \mathrm{L}$ & -3.18 & $\mathrm{ICP}$ \\
\hline $\mathrm{Cr}$ & 167 & 172 & $\mathrm{mg} / \mathrm{L}$ & -2.65 & 15.5 & 14.6 & $\mathrm{mg} / \mathrm{L}$ & 6.16 & ICP \\
\hline $\mathrm{Fe}$ & 976 & 994 & $\mathrm{mg} / \mathrm{L}$ & -1.83 & & & $\mathrm{mg} / \mathrm{L}$ & & ICP \\
\hline$K$ & 6335 & 6843 & $\mathrm{mg} / \mathrm{L}$ & -7.42 & & & $\mathrm{mg} / \mathrm{L}$ & & ICP \\
\hline $\mathrm{Mg}$ & 276 & 262 & $\mathrm{mg} / \mathrm{L}$ & 5.34 & & & $\mathrm{mg} / \mathrm{L}$ & & ICP \\
\hline $\mathrm{Mn}$ & 677 & 692 & $\mathrm{mg} / \mathrm{L}$ & -2.17 & & & $\mathrm{mg} / \mathrm{L}$ & & $\mathrm{ICP}$ \\
\hline $\mathrm{Pb}$ & 256 & 269 & $\mathrm{mg} / \mathrm{L}$ & -4.79 & 27.5 & 31.1 & $\mathrm{mg} / \mathrm{L}$ & -11.6 & ICP \\
\hline $\mathrm{Hg}$ & 404 & 400 & $\mathrm{mg} / \mathrm{L}$ & 1.00 & 0.487 & 0.48 & $\mathrm{mg} / \mathrm{L}$ & 1.46 & * \\
\hline $\mathrm{Na}$ & 41962 & 43221 & $\mathrm{mg} / \mathrm{L}$ & -2.91 & 45481 & 46000 & $\mathrm{mg} / \mathrm{L}$ & -1.13 & ICP \\
\hline $\mathrm{F}$ & 763 & 766 & $\mathrm{mg} / \mathrm{L}$ & -0.4 & 743 & & $\mathrm{mg} / \mathrm{L}$ & & IC \\
\hline $\mathrm{Cl}$ & 991 & 1010 & $\mathrm{mg} / \mathrm{L}$ & -1.88 & & & $\mathrm{mg} / \mathrm{L}$ & & IC \\
\hline $\mathrm{NO} 3$ & 249521 & 304420 & $\mathrm{mg} / \mathrm{L}$ & -18.0 & 1137 & 1116 & $\mathrm{mg} / \mathrm{L}$ & 1.88 & IC \\
\hline $\mathrm{SO} 4$ & 4717 & 4714 & $\mathrm{mg} / \mathrm{L}$ & 0.06 & & & $\mathrm{mg} / \mathrm{L}$ & & IC \\
\hline $\mathrm{CO} 3$ & & & $\mathrm{mg} / \mathrm{L}$ & & 57840 & 57600 & $\mathrm{mg} / \mathrm{L}$ & & IC \\
\hline TOC & & & $\mathrm{mg} / \mathrm{L}$ & & & 2160 & $\mathrm{mg} / \mathrm{L}$ & & \\
\hline $\mathrm{OH}$ & & & $\mathrm{mg} / \mathrm{L}$ & & & 1598 & $\mathrm{mg} / \mathrm{L}$ & & \\
\hline $\mathrm{H}$ & & 2000 & $\mathrm{mg} / \mathrm{L}$ & & & & $\mathrm{mg} / \mathrm{L}$ & & \\
\hline $\mathrm{pH}$ & -0.24 & 0.22 & s.u. & & 11.1 & 11.52 & s.u. & & $\mathrm{pH}$ meter \\
\hline Density & 1.216 & 1.217 & $\mathrm{~g} / \mathrm{mL}$ & & 1.103 & 1.115 & $\mathrm{~g} / \mathrm{mL}$ & & $\begin{array}{c}\text { Analytical } \\
\text { Balance }\end{array}$ \\
\hline
\end{tabular}

*Instrument used for Hg: ICP for INEEL Sodium Bearing Waste, CVAA for Hanford Scrubber Solution 
Table 2. Metakaolin Composition*

Oxide

$\mathrm{Al}_{2} \mathrm{O}_{3}$

$\mathrm{BaO}$

$\mathrm{CaO}$

$\mathrm{Fe}_{2} \mathrm{O}_{3}$

$\mathrm{K}_{2} \mathrm{O}$

$\mathrm{MgO}$

$\mathrm{MnO}$

$\mathrm{Na}_{2} \mathrm{O}$

$\mathrm{P}_{2} \mathrm{O}_{5}$

$\mathrm{SiO}_{2}$

$\mathrm{SrO}$

$\mathrm{TiO}_{2}$

*From Reference 8
Weight \%

36.6

0.04

0.82

1.57

0.67

0.26

0.01

0.07

$<0.05$

54.6

0.01

1.30 
Scope-01

Scope-02

Scope-03

Scope-03 alt

Scope-04

Scope-05

Scope-06

Scope-07

Scope-08

Scope-09

Scope-10

Scope-11

Scope-12

Scope-13

Scope-14

Scope-15

Scope-16

Cure90-01

Cure90-02

Cure90-03

Cure90-04

Table 3. Hydroceramic Formulations for Hanford Scrubber Waste

Sodium

Hydroxide(g) Simulant(mL) Metakaolin(g) Silica(g) Vermiculite(g)

$$
0
$$

0

40

40

40

0

40

40

40

40

30

30

40

30

30

30

30

40

40

30

40
200

200

200

200

300

200

250

350

200

200

200

200

200

250

300

250

200

200

200

200

200
130

130

130

165

130

200

200

200

130

130

130

130

130

200

200

200

130

130

130

130

165

130

65

130

$$
0
$$

65

75

75

40

0

130

0

130

65

75

75

40

0

130

65

130

$$
0
$$

30

0

0

30

0

0

40

130

10

0

0

10

0

10

5

10

10

0

0

0
Pourable? Comments

Yes Never set

Yes Never set set within 24 hours set within 24 hours set within 48 hours abandoned set within 24 hours set within 24

No hours

N/A abandoned set within 24

No hours set within 24 hours set within 24 hours set within 24 hours set within 24 hours set within 24 hours set within 24 hours set within 24

Yes hours

Yes

Yes

Yes

Yes

All "Scope" formulations cured at room temperature for at least 7 days before testing.

All "Cure90" formulations cured at 90C for 7 days, then left at room temperature until testing. 
Table 4. Hydroceramic Formulations for INEEL Sodium Bearing Waste

Sodium Hydroxide $(g)$

Scope-01

Scope-02

Scope-03

Scope-04

Scope-05

Scope-06

Scope-07

Scope-08

Scope-09

Scope-10

Scope-11

Scope-12

Scope-13
50

30

30

40

30

30

30

30

40

50

50

40

50
Waste

Simulant $(\mathrm{mL})$

200

200

200

200

200

200

200

200

200

200

200

200

200

$\begin{array}{cc}\text { Metakaolin(g) } & \text { Silica(g) } \\ 130 & 130 \\ 130 & 0 \\ 130 & 130 \\ 130 & 65 \\ 130 & 75 \\ 200 & 75 \\ 200 & 40 \\ 200 & 0 \\ 130 & 65 \\ 130 & 65 \\ 160 & 100 \\ 130 & 65 \\ 200 & 75\end{array}$

Sodium

Sulfide(g)

0

0

0

0

0

0

0

0

2

2

2

2

2
Pourable?

Yes

Yes

Yes

Yes

added water to be able to mix

No

No

Yes

Yes

Yes

No

Yes

Yes

All formulations cured at $90 \mathrm{C}$ for 7 days, then left at room temperature until testing. 


\section{PROCESSING}

Mixing was done in a one liter plastic bottle using a Lightnin mixer at 300rpm. The sodium hydroxide was added to the waste simulant and is well-mixed before adding the solids. Because this is an exothermic reaction, the mixture is allowed to cool to room temperature before adding the remaining components. All formulations were mixed/agitated for thirty minutes. Each batch would provide one or two 2-inch cubes.

We made a brief attempt to make a waste form without adding sodium hydroxide, but it was clear that the $\mathrm{pH}$ adjustment provided by the base is necessary for proper fabrication.

Vermiculite additions were tried, but seemed only to increase the volume of the waste form unnecessarily. Its use was discontinued early in the study.

Pretreatment of the Hanford waste with phosphoric acid was considered, but when stable waste forms were made without it, the idea was no longer pursued.

Sodium sulfide $\left(\mathrm{Na}_{2} \mathrm{~S}\right)$ was used in an attempt to improve the setting time and leachability.

Whether or not the mixture will pour is an important aspect of the eventual processing of the material. Appropriate notes are provided in the table.

Curing at room temperature did not appear to result in an adequate waste form, so we began curing the materials at $90 \mathrm{C}$ for seven days. Because we still did not obtain very good results, in order to get the proper acceleration of chemical reactions, it may be necessary to increase the time.

\section{TESTING AND CHARACTERIZATION}

Compressive strength testing (ASTM C39) was used to monitor the structural integrity of the waste form. The Toxicity Characteristics Leach Procedure (TCLP) was used as a gauge of the durability of the waste form.

We judged as acceptable a waste form with a compressive strength greater than 500psi (results are in Tables 5 and 6) and durable enough to pass the Toxicity Characteristics Leach Procedure (TCLP) (Table 7).

Only two formulations, SBW-Scope-11 and SBW-Scope-13, resulted in materials strong enough to justify running the TCLP. Both of these waste forms failed for mercury, but passed for cadmium, chromium, and nickel.

Based on the initial compressive strength tests, we made two large batches of both of these formulations with the intention of submitting them for final evaluation. These larger batches were made in a much larger container (six liters) using a Hobart mixer. They were again mixed for 30 minutes. Each batch made 142 inch cubes. Unfortunately, none of these cubes had a compressive strength of greater than 500psi (Table 7). 
Table 5. Hanford Scrubber Waste Compressive Strength

$$
\text { Compressive }
$$

Scrubber-Scope-01

Strength(psi)

Scrubber-Scope-02

Scrubber-Scope-03

Scrubber-Scope-03

Scrubber-Scope-03 alt

$\mathrm{N} / \mathrm{A}$

Age at Testing (days)

Scrubber-Scope-03 alt

Scrubber-Scope-04

Scrubber-Scope-04

Scrubber-Scope-05

N/A

N/A

150

$\mathrm{N} / \mathrm{A}$

171

12

48

128

13

176

49

54

12

72

48

N/A

N/A

Scrubber-Scope-06

80

13

Scrubber-Scope-06

180

49

Scrubber-Scope-07

Scrubber-Scope-07

55

13

Scrubber-Scope-08

Scrubber-Scope-09

Scrubber-Scope-10

Scrubber-Scope-11

Scrubber-Scope-12

Scrubber-Scope-13

Scrubber-Scope-14

Scrubber-Scope-15

Scrubber-Scope-16

Scrubber-Cure90-01

Scrubber-Cure90-02

Scrubber-Cure90-03

Scrubber-Cure90-04

94

49

N/A

N/A

240

43

91

43

126

43

220

42

160

41

62

41

75

40

111

40

251

14

170

14

178

14

181

14 
Table 6. INEEL Sodium Bearing Waste Compressive Strength Compressive

Strength(psi)

SBW-Scope-01

73

SBW-Scope-01

SBW-Scope-02

SBW-Scope-02

SBW-Scope-03

SBW-Scope-03

SBW-Scope-04

SBW-Scope-04

SBW-Scope-05

SBW-Scope-05

SBW-Scope-06

SBW-Scope-07

SBW-Scope-08

SBW-Scope-09

SBW-Scope-10

SBW-Scope-11

SBW-Scope-12

SBW-Scope-13

297

65

81

Age at Testing (days)

SBW-Final-11

262

12

54

67

123

133

173

117

83

12

54

12

SBW-Final-11

183

12

54

12

54

12

195

54

189

19

81

19

127

19

338

19

549

19

188

19

624

19

SBW-Final-11

136

19

SBW-Final-11

157

139

167

136

11

SBW-Final-13

SBW-Final-13

SBW-Final-13

243

11

SBW-Final-13

271

11

11

12

12

12

12

SBW-Final-13

13 
Table 7. INEEL Sodium Bearing Waste TCLP Results

SBW Scope 11

Sample \#1

Sample \#2

Sample \#3

\section{SBW Scope 13}

Sample \#1

Sample \#2

Sample \#3
Cadmium

$(\mathrm{mg} / \mathrm{L})$

0.535

0.633

0.600

0.589

0.050

8.46

RSD (\%)

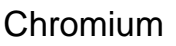

(mg/L)

0.002

0.004

0.003

0.003

0.001

33.33

0.431

0.337

0.359

Average

0.376

0.049

13.09

Std. Dev.

RSD (\%)

0.00

0.00

0.00

0.00

0.000

-
Nickel

(mg/L)

0.039

0.034

0.123

0.065

0.050

76.54
Mercury

$(\mu \mathrm{g} / \mathrm{L})$

143

81.8

148

124

36.808

29.64

0.021

0.033

47.1

0.037

0.834

$\mathbf{0 . 0 3 0}$

0.063

0.008

16.0

27.45

26.916

168.36

\section{Limits}

RCRA

UTS

$\begin{array}{cccc}1.0 & 5.0 & - & 200 \\ 0.11 & 0.60 & 11.00 & 25\end{array}$




\section{MATERIALS SUBMITTED}

Despite the lack of strength, we submitted 20 samples of the SBW-Final-11 formulation. It seems to be much more stable than the SBW-Final-13 formulation, the latter being very soft and friable to the touch.

Figures 1-5 illustrate various aspects of the manufacture of the final samples. Figure 1 is the Hobart mixer used. The mixing action is shown in Figure 2. Figure 3 shows the 2-inch cube just after putting the batch into the mold. Figure 4 shows the finished product (after curing).

The density of this material is $1.11 \mathrm{~g} / \mathrm{cm}^{3}$. The composition is provided in Table 8 . The waste loading is estimated to be about $15 \%$, based on a calculation of the amount of sodium in the simulant with the amount of sodium in the waste form.

\section{WASTE PROCESSING TECHNOLOGY}

Manufacture of a hydroceramic grout waste form is a straightforward cement production process. What follows is a brief list of the facilities needed and the expected process steps necessary to produce an acceptable waste form.

Facilities required are:

1. Waste storage tank(s)

2. Raw material storage tanks
a. Sodium hydroxide
b. Metakaolin
c. Silica
d. Sodium sulfide
e. Water

3. Feed delivery systems

a. Gravimetric, loss-in-weight system for dry materials

b. Metered system for liquid(s)

4. Mixing tank
a. Planetary mixer
b. Bottom discharge
c. Variable speed drive
d. Stainless steel

5. 55-gallon drums as waste package

6. Storage facility for waste packages

7. Auxiliary facilities

a. Lab

i. Feed and raw material chemistry

ii. Waste form chemistry

iii. Compressive strength

b. Receiving stations for raw materials, etc.

c. Records management 
The process steps include:

1. Waste transfer and sampling

2. Recipe calculation

3. Addition of raw materials

4. Mixing

5. Sampling of waste form (frequency TBD)

6. Delivery of waste form to 55-gallon drums

7. Movement of drums to storage facility

The entire process, of course, would be carried out in a facility isolated in order to contain the radioactive constituents and for personnel protection.

As would be expected, there are issues of scale-up from the laboratory testing reported herein. The method of sampling the finished product and the frequency of sampling are issues that would be resolved in an extensive process development effort. The use of 55-gallon drums suggested here is simply for convenience and not necessarily based on requirements for final disposal of the waste form.

\section{DISCUSSION}

Similar work has been done in the past by Bao at Penn State [8] and DIAL $[9,10]$ on slightly different wastes. The work by Bao was with a simulated Hanford sodium bearing waste. The work at DIAL was with a simulated calcine waste from the Idaho National Lab. Neither of these studies produced particularly good waste forms.

None of the materials made by Bao showed a compressive strength over 500psi. The waste forms made for the INL calcine proved to have a compressive strength near 500psi, but did not pass the TCLP. (Leach tests done by Bun could not be compared with TCLP.)

Some suggestions for improvements might be as follows:

- Higher curing temperatures

- Longer curing times

- Chemical or thermal pretreatment of waste to adjust nitrite/nitrate ratio

Additionally, a fuller characterization of the waste forms could lead to some clues to improvements. Scanning electron microscopy or x-ray diffraction would be helpful to learn the phases present in the waste forms and then lead to conclusions as to how to create the optimal phases necessary for an acceptable waste form. 


\section{QUALITY ASSURANCE}

Activities were performed under a Quality Assurance program using procedures similar to those developed for the development of stabilizers for the ICP-SP3 Calcine Disposition Project. These guidelines are described in a document, Quality Assurance Project Plan for ICP-SP3 Calcine Disposition Project, DIALCO04-ID-QAPP Rev. 2 developed by DIAL in compliance with the quality assurance requirements of the OCRWM DOE/RW 0333P rev. 14.

All the steps of the preparation of the waste form will be recorded in a laboratory notebook. Quality assurance (QA) guidelines will be explicitly listed for experimental procedures, documenting procedures and results, archiving desired test samples, and disposal of remaining test samples and remaining calcine simulants at the end of the project.

The laboratory notebooks used for record keeping of experimental development and observations were signed, dated and witnessed each day during experimentation. The notebooks are available for inspection by PNNL and archived by DIAL for the life of the project and will be available for a period not less than 15 years after project completion.

The DIAL/MSU data will be considered an integral and traceable part of the Low Temperature Waste Immobilization Process that can be used to verify the preferred waste form formulation and stabilization method via the quality assurance requirements of DOE/RW-0333P. Hard copies of the laboratory notebooks will be provided by DIAL to PNNL as required.

\section{SUMMARY}

We have submitted for your testing 202 -inch cubes of the formulation SBW-Final-11. It represents the best material we have made during this study, although it is perhaps only borderline in its properties as an acceptable material.

During this project, the protocol and materials used did not produce an acceptable waste form. It is possible that the hydroceramic method may, upon expanding the range of materials and methods to be tested, might still provide an acceptable waste form. 
Table 8. Chemical Analysis of INEEL SBW-Final-11.

INEEL Sodium

Bearing Waste

Analyte

Al

B

$\mathrm{Ca}$

$\mathrm{Cd}$

$\mathrm{Cr}$

$\mathrm{Fe}$

$\mathrm{K}$

$\mathrm{Mg}$

$\mathrm{Mn}$

$\mathrm{Pb}$

$\mathrm{Si}$

$\mathrm{Hg}$

$\mathrm{Na}$

F

$\mathrm{Cl}$

$\mathrm{NO} 3$

$\mathrm{SO} 4$

$\mathrm{CO} 3$

TOC

$\mathrm{OH}$

$\mathrm{H}$
Final-11

Formulation

Tested Unit

$10.6 \quad \mathrm{wt} \%$

0.00875

0.117

0.00275

0.016

0.18625

0.3775

0.02725

0.0625

0.0115

22.8775

0.019

10.1

$<0.05$

0.48

12.5

0.86 wt $\%$

$w t \%$

$w+\%$

$w t \%$

wt\%

$w t \%$

$w t \%$

$w t \%$

$w t \%$

$w t \%$

$w t \%$

wt $\%$

$w t \%$

$w t \%$

wt $\%$

$w t \%$

wt $\%$

wt $\%$

$w t \%$

wt $\%$

\section{Instrument}

used

for testing

ICP

ICP

ICP

ICP

ICP

ICP

ICP

ICP

ICP

ICP

ICP

ICP

ICP

IC

IC

IC

IC

IC 


\section{REFERENCES}

1. M. W. Grutzeck, B. E. Scheetz, J. Olandrewaju , N. Krishnamurthy and D. D. Siemer, "Development of Hydroceramic Waste forms", Ceramic Transactions, Vol. 119, pp 383-390, 2001.

2. D. D. Siemer, "Performance of Hydroceramic Concretes on Radwaste Leach Tests", Ceramic Transactions Vol. 132, pp 369-379, 2002.

3. D. D. Siemer, D. M. Roy, M. W. Grutzeck, and B. E. Scheetz, "Cementitious Solidification of DOE's Legacy Reprocessing Waste", Proceedings of the $9^{\text {th }}$ Biennial International Spectrum Conference, Reno, NV, August 4-8, 2002.

4. B. E. Scheetz and J. Olanrevaju, "Determination of the rate of formation of hydroceramic waste forms made with INEEL calcined wastes", Final Report, Contract \# DE-FG07-98D13649, 15 October 2001.

5. http://emsp.em.doe.gov/EMSPprojects1996_2003/High/653662001.pdf

6. D. D. Siemer, M. W. Grutzeck, D. M. Roy , M. L. Gougar , \& B. E. Scheetz „ "Zeolite Waste Forms Synthesized from Sodium Bearing Waste and Metakaolinite", Proceedings of WM'98 Conference, Tucson , AZ, March 1998.

7. T. R. Thomas and K.F. Childs, "Down Selection of Candidate Technologies for Calcine Stabilization Studies," EDF-4753, April 21, 2004.

8. Bao, Yun, "Design and Characterization of Microporous Zeolitic Hydroceramic Waste Forms for the Solidification and Stabilization of Sodium Bearing Wastes," a thesis in Materials Engineering, The Pennsylvania State University, August 2005.

9. Giordana, A., R. A. Palmer, M. McCarthy, D. Patterson, Y. Xia, M. Bricka, A. Marwaha, M. Henderson, C. Williams, and T. R. Thomas. "Low Temperature Stabilization of High Level Calcined Waste," poster presentation at WM'05 - 31 ${ }^{\text {st }}$ Waste Management Symposium, February 2005.

10. Palmer, R. A., M. Bricka, and B. Kauffman, "DIAL/MSU Development of Stabilizers for High Level Waste Calcine," Annual Progress Report, October 1, 2004 to September 30, 2005, DIAL/ICP-Calcine Disposition Project-AR2005-001, September 30, 2005. 


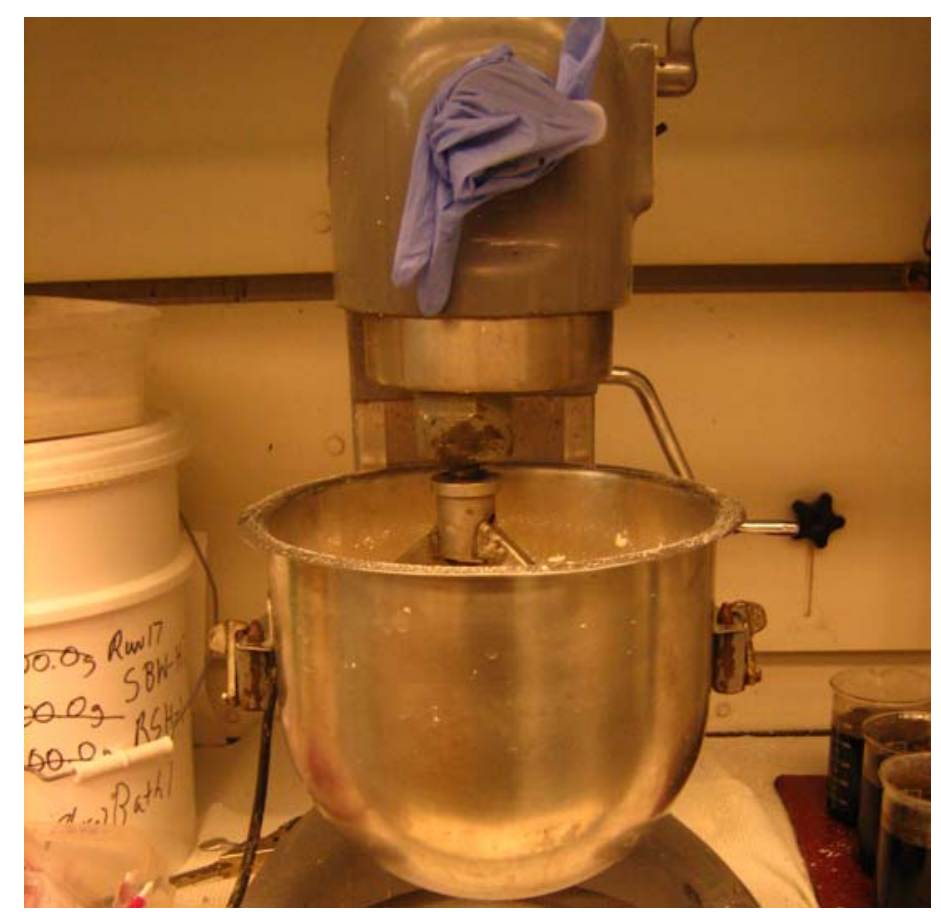

Figure 1. Hobart mixer. 


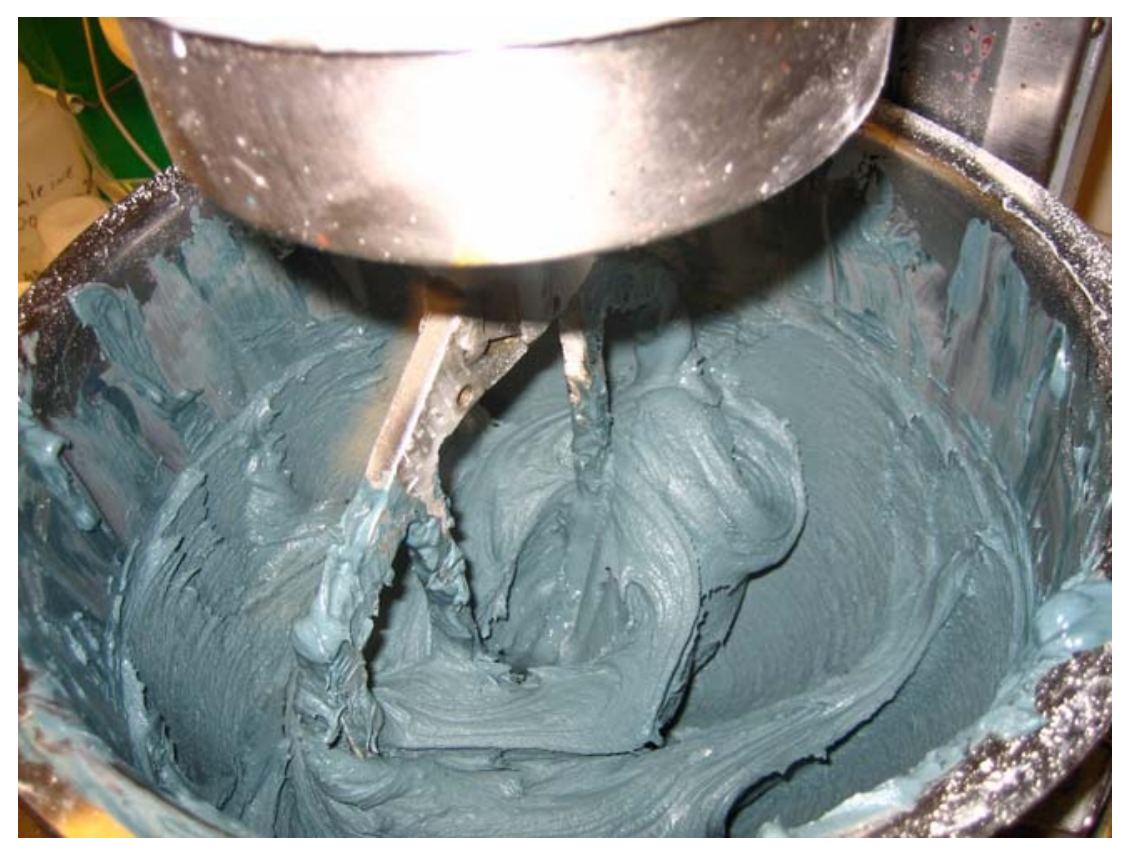

Figure 2. Mixing action. 


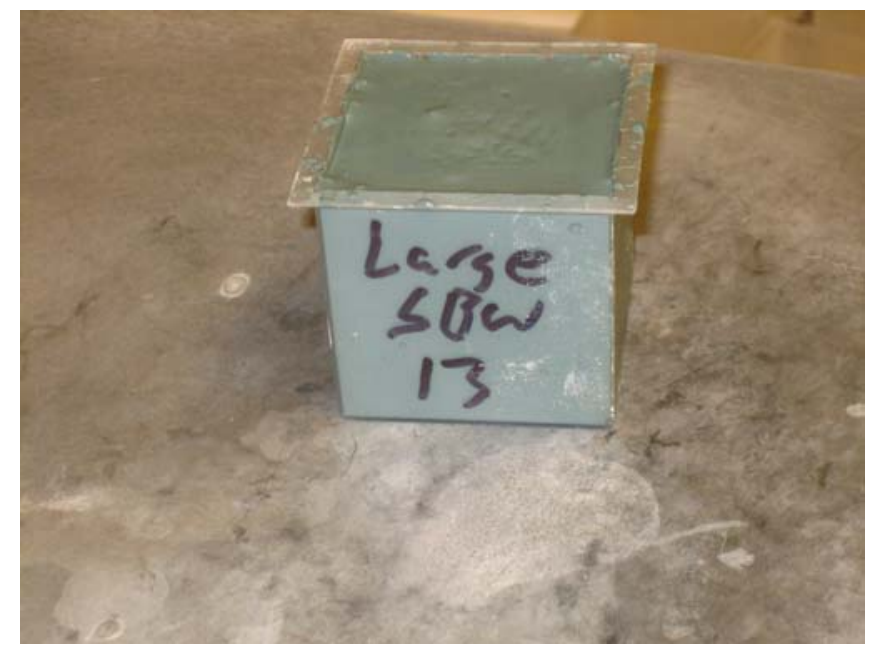

Figure 3. 2-inch cube in the mold. 


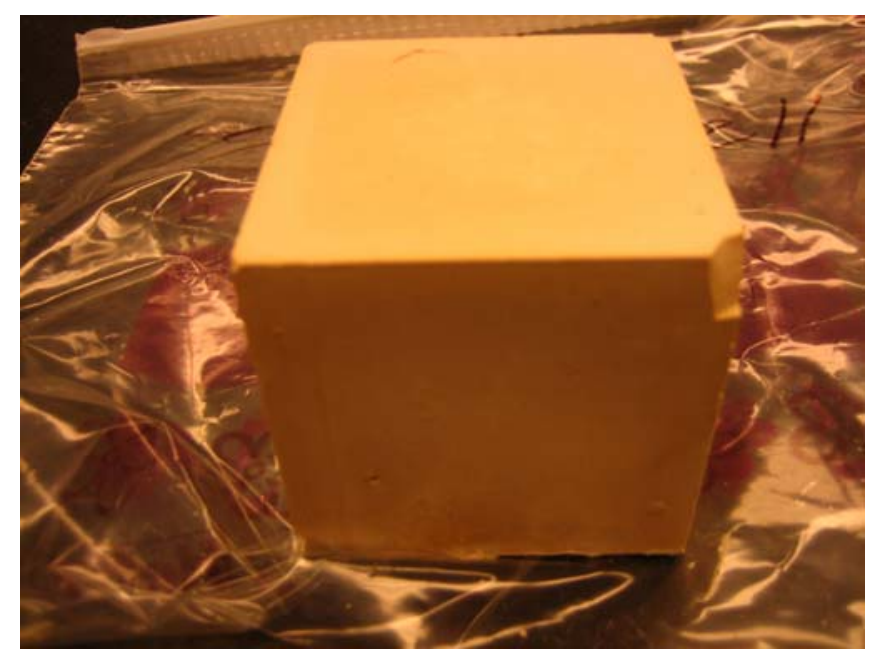

Figure 4. Finished 2-inch cube (after curing). 
PNNL-16052 1

\section{Distribution List}

No. of

\section{Copies}

\section{OFFSITE}

1 D. Maloney

CH2MHill Nuclear Group

9191 Jamaica Street

Englewood, CO 80112

1 R. A. Palmer

Diagnostic Instrumentation \& Analysis

Laboratory

Mississippi State University

205 Research Boulevard

Starkville, MS 39759

$1 \quad$ I. L. Pegg

Vitreous State Laboratory

The Catholic University of America

620 Michigan Ave. NE

Washington D.C. 20064

3 U.S. Department of Energy Idaho

U.S. Department of Energy

Idaho Operations Office

850 Energy Drive

Idaho Falls, ID 83401

Attn: J. Case

W. A. Ocwa

S. Van Camp
No. of

Copies

\section{ONSITE}

4 CH2M Hill Hanford Group, Inc.

M. E Johnson

H6-19

J. D. Kristofzski H6-03

D. Parker H6-03

R. E. Raymond S7-83

1 DOE Office of River Protection
B. M. Mauss
H6-60

21 Pacific Northwest National Laboratory

L. M. Bagaasen

K6-28

T. M. Brouns

K9-69

A. B. Gallegos

K6-24

P. R. Hrma

K6-24

G. B. Josephson

K9-69

S. G. Pitman

P8-15

R. L. Russell (5)

K6-24

M. J. Schweiger

K6-24

R. J. Serne

P7-22

D. M. Strachan

K6-24

M. R. Telander

P7-82

J. D. Vienna

K6-24

J. H. Westsik, Jr. (5)

K7-15

Distr. 1 